FREDDY POETSCHER

EFEITO DO NÚMERO DE PASSES E DO TRATAMENTO TÉRMICO PÓS-SOLDAGEM DE LIGA DE ALUMÍNIO AA 6063 SOLDADA POR ATRITO LINEAR COM MISTURA (FSW). 
FREDDY POETSCHER

\section{EFEITO DO NÚMERO DE PASSES E DO TRATAMENTO TÉRMICO PÓS-SOLDAGEM DE LIGA DE ALUMÍNIO AA 6063 SOLDADA POR ATRITO LINEAR COM MISTURA (FSW).}

Tese apresentada à Escola Politécnica da Universidade de São Paulo como requisito para obtenção do título Doutor em Engenharia

Área de Concentração: Engenharia Metalúrgica e de Materiais

Orientador: Sérgio Duarte Brandi 
Este exemplar foi revisado e alterado em relação à versão original, sob responsabilidade única do autor e com a anuência de seu orientador.

São Paulo, de Junho de 2009.

Assinatura do autor

Assinatura do orientador

FICHA CATALOGRÁFICA

Poetscher, Freddy

Efeito do número de passes e do tratamento térmico póssoldagem de liga de alumínio AA 6063 soldada por atrito linear com mistura (FSW) / Freddy Poetscher; orientador Sérgio Duarte Brandi. - ed.rev. -- São Paulo, 2009.

$163 \mathrm{p}$.

Tese (Doutorado) - Escola Politécnica da Universidade de São Paulo. Departamento de Engenharia Metalúrgica e de Materiais.

1.Soldagem por FSW 2.Soldagem no estado sólido 3.Soldagem por atrito linear com mistura (SALM) 4.Alumínio I. Universidade de São Paulo. Escola Politécnica. Departamento de Enqenharia Metalúraica e de Materiais II.t. 
"Que eu queira o que Deus quer que eu queira."

São Tomaz de Aquino 
À minha amada esposa Sylvia, minha alma gêmea companheira. Aos meus filhos Erich e Johann, minha eternidade. 


\section{AGRADECIMENTOS}

Agradeço ao meu orientador Prof. Dr. Sérgio Duarte Brandi pelo acolhimento, convivência e uma orientação livre, precisa e sempre presente.

Ao Departamento de Engenharia Metalúrgica e de Materiais da Escola Politécnica pela estrutura de apoio técnica e administrativa para a condução deste trabalho.

À empresa CBA pelo fornecimento dos materiais e suporte nos ensaios, em especial aos Srs. Miguel Borodiak, Alex Sandro Felipe de Moraes e Ivan Menegueço pelo auxílio nas preparações das amostras e ao Mestre Eng. Rodrigo Camargo Campana pelo suporte na CBA.

Ao IST-Lisboa-Portugal pela soldagem dos corpos de prova, em especial a Prof. Dra. Luisa Quintino e ao Prof. Dr. Pedro Vilaça.

Ao aluno de intercâmbio Jean-Baptiste Chesnot da Ėcole Nationale Supérieure de Chimie de Lille - França pela ajuda na preparação e condução dos ensaios iniciais de calorimetria.

Ao Laboratório de Fenômenos de Superfície (LFS) pela ajuda na preparação de amostras e medidas de microdureza.

Ao Prof. Alberto do Dema UFSCar pelas orientações e ensaios de EBSD.

Ao IPT pelo suporte nos ensaios e preparações de amostras, em especial ao Sr. José Belotti.

Ao Prof. Dr. Ricardo H.R. Castro da FEl pela ajuda nos ensaios de calorimetria.

Aos Técnicos Vinícios, Aline, Luan, Lívio e Cláudio que ajudaram na preparação de amostras.

Aos colegas de Pós Dário, Eduardo, Maria, Flávio, Riccardo, Franco pela convivência e ajuda nos momentos de dificuldades.

Aos colegas da Testmat, Eng. Cristiano Lagatta e Eng. João Alves, que ajudaram na realização dos ensaios e na minha ausência na empresa.

Aos colegas da Voith que direta ou indiretamente ajudaram na realização deste trabalho. 


\section{RESUMO}

O processo de soldagem por atrito linear com mistura (FSW) é uma técnica recente para a soldagem no estado sólido de materiais, em particular para o alumínio e suas ligas. O processo foi inventado na Inglaterra em 1991. Neste processo, as partes a serem soldadas são fixadas e uma ferramenta especial realiza a soldagem de forma contínua. A ferramenta possui uma velocidade de rotação e, durante a sua translação, o material é misturado no estado sólido e, conseqüentemente, soldando as duas partes. A junta soldada por FSW de alumínio AA 6063-T6, com espessura de $3 \mathrm{~mm}$ foi caracterizada. A soldagem foi realizada com uma rotação da ferramenta de $710 \mathrm{rpm}$ e com uma velocidade de translação de $5,3 \mathrm{~mm} / \mathrm{s}$. A ferramenta empregada é do tipo 'three flats', com diâmetro do ombro de $14 \mathrm{~mm}$, diâmetro do pino de $3 \mathrm{~mm}$ e com ângulo de $90^{\circ} \mathrm{com}$ relação à horizontal. Os corpos de prova foram soldados em três condições: um passe, dois passes e dois passes com inversão de rotação do pino. Após a soldagem foram realizados os seguintes tratamentos térmicos: solubilização, envelhecimento e recozimento. A junta soldada foi caracterizada por macrografias, micrografias, microdureza, ensaios de calorimetria diferencial e EBSD. Os resultados mostraram que existem ZTMA's diferentes conforme a condição dos de passes. O número de passes tem influência nas componentes da textura alterando de Cubo para Latão e para Goss + Cobre. Os tratamentos térmicos de envelhecimento e recozimento produziram as maiores e menores durezas do cordão, respectivamente. Foi observada a sinergia entre os fatores número de passes e região do cordão no tamanho de grão do cordão. O lado de retrocesso, após o tratamento térmico, apresentou os grãos mais finos.

Palavras-chave: Soldagem por FSW. Soldagem no estado sólido. Soldagem por atrito linear com mistura (SALM). Alumínio. 


\begin{abstract}
Friction stir welding (FSW) is a recent process for aluminium welding in solid state. This process was invented in England in 1991. The welding process is done with a special rotating tool that travels along the joint while the parts are fixed. The tool has a speed and a rotation and during its translation the material mixtures in solid state and the joint occurs. The objective of this paper is to show the metallurgical and mechanical characteristics of a $3 \mathrm{~mm}$ thick Aluminum AA 6063 T6 plate welded joint. The tool rotation speed was $710 \mathrm{rpm}$ and the translation speed was $5.3 \mathrm{~mm} / \mathrm{s}$. The type of the tool used was 'three flats', with a shoulder diameter of $14 \mathrm{~mm}$ and pin diameter of $3 \mathrm{~mm}$ and perpendicular to the plate. The samples were welded in three conditions: one pass, two passes and two passes with pin rotation inversion in the second pass. The welded samples were also submitted to solution heat treatment, solution heat treatment followed by aging and annealing heat treatments. The welded joint was studied with these main experimental techniques: optical and scanning electron microscopy, microhardness, differential scanning calorimetry and electron backscatter diffraction for texture analysis. The results showed different TAZ's according to the welding conditions. The number of passes has influence over the texture components changing from Cube to Brass and to Goss + Copper. The aging and solution heat treatments showed the highest and the lowest hardness, respectively. Synergy between the welding conditions and weld region was observed for the grain size results. The retreating side produced the finest grains after heat treating.
\end{abstract}

Key-words: Friction stir welding (FSW). Solid state welding. Aluminium. 


\section{LISTA DE ILUSTRAÇÕES}

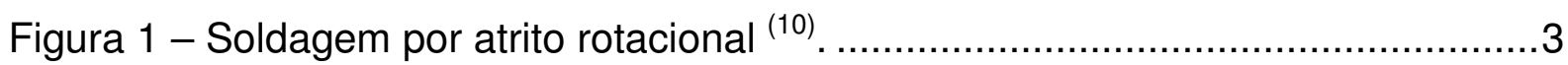

Figura 2 - Processo de soldagem por atrito linear com mistura ${ }^{(10)}$. .......................... 4

Figura 3 - Ensaio de Fadiga. Número de ciclos até a ruptura para alumínio série 6000. a) Comparação MIG, SALM e Material de Base, b) Comparação SALM, Cordão de solda obtido por SALM polido e Material de Base ${ }^{(16,17)}$..............................................

Figura 4 - Comparativo de três processos para a soldagem de juntas topo a topo de ligas de alumínio da série AA $6000^{(27)}$..................................

Figura 5 - Esquema do processo SALM. Adaptado das referências ${ }^{(28,29)}$...............10

Figura 6 - Exemplos de ferramenta: (a) convencional, (b) tipo Whorl ${ }^{\mathrm{TM}} \mathrm{e}$

(c) MX Triflute ${ }^{\mathrm{TM}}$, desenvolvidas pelo TWI ${ }^{(33)}$.

Figura 7 - SALM duplo. Realizado com duas ferramentas em ambos os lados de um perfil típico ${ }^{(34)}$.

Figura 8 - SALM na fabricação de tubos não ferrosos ${ }^{(34)}$..................................... 12

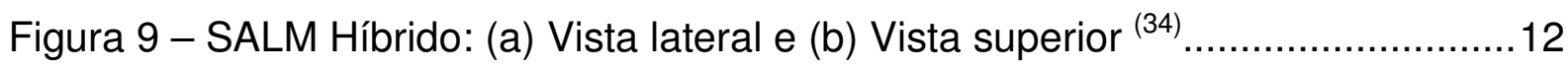

Figura 10 - Coordenadas do modelo de McClure ${ }^{(45)}$.............................................14

Figura 11 - Ciclos térmicos para a condição $2 \mathrm{D}$ em uma distância de $8,185 \mathrm{~mm}$ do centro do cordão para AA 6056-T4 com 3,9 $\mathrm{mm}$ de espessura, representando de (a) até (c) o melhor ajuste entre os valores medidos experimentalmente e os previstos pelo modelo analítico. Potência do processo $745 \mathrm{~W}$ (47).

Figura 12 - Resultados da interação do pino da ferramenta Triflat com velocidade translação de $1 \mathrm{~mm} / \mathrm{s}$ e velocidade de rotação de 120 rpm para liga de alumínio AA 7449 com $20 \mathrm{~mm}$ de espessura. (a) contornos dos valores da velocidade $(\mathrm{m} / \mathrm{s})$; (b) vetores velocidade (mostrando uma superfície com taxa de deformação de $1 \mathrm{~s}^{-1}$ ); (c) taxa de deformação em s${ }^{-1}$ (observar que a escala é logarítmica); (d) contornos de temperatura $\left({ }^{\circ} \mathrm{C}\right)^{(48)}$. 
Figura 13 - Contornos de pressão $(\mathrm{Pa})$ do pino da ferramenta Triflat com velocidade translação de $1 \mathrm{~mm} / \mathrm{s}$ e velocidade de rotação de $120 \mathrm{rpm}$ para liga de alumínio AA $7449 \mathrm{com} 20 \mathrm{~mm}$ de espessura ${ }^{(48)}$.

Figura 14 - Ciclo térmico para uma liga AA6082 obtido na região logo abaixo do ombro da ferramenta ${ }^{(42,49)}$

Figura 15 - Medidas de dureza experimentais e calculadas pelo modele em liga de alumínio AA6082-T6. Parâmetros de soldagem: velocidade de $5 \mathrm{~mm} / \mathrm{s}$; velocidade de rotação do pino de $1500 \mathrm{rpm}$ e força de $7 \mathrm{kN}^{(42,49)}$.

Figura 16 -Efeito do tratamento térmico na microestrutura da junta soldada por SALM da liga AA6082-T6. Em (a) na condição como-soldada e em (b) tratada a $510^{\circ} \mathrm{C}$ por $15 \mathrm{~min}{ }^{(42,49)}$. 22

Figura 17 - a) Diagrama de Ashby. b) Diagrama de Ashby para a região do cordão de solda ${ }^{(40,43)}$

Figura 18 - Definição das regiões de deformação na soldagem SALM, na parte de trás do pino ${ }^{(50)}$

Figura 19 -Efeito da velocidade de avanço e de rotação nas regiões de deformação de material durante a soldagem por SALM de uma liga de alumínio ${ }^{(55)}$. 28

Figura 20 - Representação esquemática do crescimento (a) normal (b) anormal de grãos de tamanho médio $D$ ao longo do tempo $t$ (58)

Figura 21 - Zona termo-mecanicamente afetada pelo calor: A- Material não afetado; B- Termicamente afetado; C- Termomecanicamente afetado - plasticamente deformado, com áreas recristalizadas; D- Dinamicamente recristalizado ${ }^{(19)}$... 35

Figura 22 - Perfil de dureza para cordão de Al 6063 soldado por SALM (68)

Figura 23 - TEM da solda SALM com precipitados em diferentes regiões $(54,68)$

Figura 24 - Curva do fluxo de energia obtida por calorimetria diferencial em amostras de cordão de solda AA 6005 em diferentes regiões do cordão e material de base ${ }^{(71)}$ 
Figura 25 - (a) Padrões de fluxo de material. Seção longitudinal da ferramenta, junta e cordão. (b) regiões desenvolvidas durante o processo SALM ${ }^{(82)}$.

Figura 26 - a) Componentes de textura de laminação de metais CFC no espaço de Euler em 3D: a fibra $\beta$ entre a componente cobre e latão e a fibra $\alpha$ entre a componente do tipo latão e Goss. b) As seções constantes $\varphi_{2}$.

Figura 27 - Mapas EBSD e figuras de pólo $<100>$ na condição como soldado, a) b) e c) referem-se a três regiões no centro do cordão na região do onion ring ${ }^{(83)}$.

Figura 28 - a) Fotografia do cordão soldado com um passe. As setas indicam a direção e rotação da ferramenta. b) Detalhe do tipo da ferramenta utilizada.

Figura 29 - Diferentes condições de soldagem. a) 1 passe b) 2 passes na mesma direção c) dois passes com direção inversa de rotação do pino. 48

Figura 30 - Regiões de análise do cordão de solda por SALM. 49

Figura 31 - Esquema das medidas das áreas da zona termomecanicamente afetada na vista frontal do cordão de solda. A soma das áreas indicadas corresponde a área total do cordão. As áreas 1 e 2 correspondem a ZTMA 53

Figura 32 -Matriz de experimentos com dois fatores: Pressão e Lote e dois níveis por fator. Os números dentro da matriz indicam a seqüência de ensaios. 57

Figura 33 - Arranjo fatorial de dois fatores com dois níveis ${ }^{(99)}$ 58

Figura 34 - Gráfico dos efeitos de interação. Os símbolos + e - indicam o nível do fator no máximo e no mínimo. (a) Fator $A$ sem interação com Fator B (b) Fator A com interação com Fator $\mathrm{B}^{(99)}$. .60

Figura 35 - Matriz de experimentos de dois fatores com a e $b$ níveis e $n$ replicações, $y=$ resposta ${ }^{(99)}$. 
Figura 36 - Microestruturas frontais das seções dos cordões. (a) 1 passe Como Soldado (b) 2 passes sem inversão Como Soldado (c) 2 passes com inversão Como Soldado. Ataque: Barker $1,8 \%$.

Figura 37 - Microestruturas da vista superior dos cordões. (a) 1 passe Como soldado (b) 2 passes sem inversão Como soldado (c) 2 passes com inversão Como soldado. Ataque: Barker 1,8\%. 65

Figura 38 - Microestruturas da vista da raiz dos cordões. (a) 1 passe Como Soldado (b) 2 passes sem inversão Como Soldado (c) 2 passes com inversão Como Soldado. Ataque: Barker $1,8 \%$. 66

Figura 39 - Microestrutura da zona termomecanicamente afetada do cordão da condição de um passe, lado do avanço, vista frontal. .71

Figura 39 - Gráfico dos efeito das condições de soldagem no tamanho de grão médio na região de grãos alongados. .72

Figura 40 - Efeito das interações no tamanho de grão alongado. .73

Figura 42 - Microestrutura do centro do cordão mostrando os grãos equiaxiais. 75

Figura 43 - Efeito da condição de soldagem no tamanho de grão equiaxial. 75

Figura 43 - Microestrutura do metal de base na condição como-recebido.. Ataque: Barker $1,8 \%$ .77

Figura 44 - Microestruturas frontais das seções dos cordões. (a) 1 passe Solubilizado (b) 2 passes sem inversão Solubilizado (c) 2 passes com inversão Solubilizado. Ataque: Barker 1,8\%. 79

Figura 45 - Microestruturas frontais das seções dos cordões. (a) 1 passe Envelhecido (b) 2 passes sem inversão Envelhecido (c) 2 passes com inversão Envelhecido. Ataque: Barker 1,8\%. .80

Figura 46 - Microestruturas frontais das seções dos cordões. (a) 1 passe Recozido, 2h (b) 2 passes sem inversão Recozido $2 \mathrm{~h}$ (c) 2 passes com inversão Recozido 2h. Ataque: Barker 1,8\%. .81 
Figura 47 - Microestruturas frontais das seções dos cordões. (a) 1 passe Recozido, 8h (b) 2 passes sem inversão Recozido 8h (c) 2 passes com inversão Recozido 8h. Ataque: Barker 1,8\%. 82

Figura 48 - Microestruturas da vista superior dos cordões. (a) 1 passe Solubilizado (b) 2 passes sem inversão Solubilizado (c) 2 passes com inversão Solubilizado. Ataque: Barker 1,8\%. 83

Figura 49 - Microestruturas da vista superior dos cordões. (a) 1 passe Envelhecido (b) 2 passes sem inversão Envelhecido (c) 2 passes com inversão Envelhecido. Ataque: Barker 1,8\%. 84

Figura 50 - Microestruturas da vista superior dos cordões. (a) 1 passe Recozido 8h (b) 2 passes sem inversão Recozido 8h (c) 2 passes com inversão Recozido 8h. Ataque: Barker 1,8\%. 85

Figura 51 - Microestruturas da vista da raiz dos cordões. (a) 1 passe Solubilizado (b) 2 passes sem inversão Solubilizado (c) 2 passes com inversão Solubilizado. Ataque: Barker 1,8\%. 86

Figura 52 - Microestruturas da vista da raiz dos cordões. (a) 1 passe Envelhecido (b) 2 passes sem inversão Envelhecido (c) 2 passes com inversão Envelhecido. Ataque: Barker 1,8\%.

Figura 53 - Microestruturas da vista da raiz dos cordões. (a) 1 passe Recozido 8h (b) 2 passes sem inversão Recozido 8h (c) 2 passes com inversão Recozido 8h. Ataque: Barker 1,8\%. 88

Figura 54 - Gráfico de fração recristalizada ao longo do tempo para o recozimento. Curvas para fração recristalizada total. Os símbolos indicam os valores medidos. 89

Figura 55 - Recristalização secundária avançando da superfície para o centro do cordão. Soldagem com um único passe, lado do avanço. Ataque: Barker. 90

Figura 56 - Efeito das condições de soldagem, tratamento térmico posterior e localização na área de recristalização secundária do cordão.

Figura 57 - Análise de ANOM indicando os efeitos significativos na alteração da área recristalizada secundariamente durante 0 recozimento dos cordões de solda 
Figura 58 - Efeitos do tratamento térmico de recozimento, condição do cordão e localização no tamanho de grão equiaxial.

Figura 60 - Efeitos do tratamento térmico e localização no tamanho de grão da ZTMA.

Figura 61 - Efeitos das interações entre localização no cordão e condição de soldagem. .98

Figura 62 - Mapa de orientação do grão. Material de base apresentando uma textura na direção <001> 100

Figura 63 - Mapa de índice de qualidade de ensaio (IQ). Material de Base. 101

Figura 64 - Diferença de orientação entre grãos do material de base. 101

Figura 65 - Diferença de orientação entre grãos do material de base. 102

Figura 66 - FDO (EBSD) obtida para o material de base. 103

Figura 67 - Tamanho de grão do metal de base. 103

Figura 68 - Porcentagem acumulada da distribuição dos tamanhos de grão obtidos por EBSD do Material de Base. 104

Figura 69 - Mapa de orientação de grão para a condição de um passe.

Região de avanço da ferramenta. 105

Figura 70 - Diferença de orientação dos grãos para a condição de um passe. Região de avanço da ferramenta 106

Figura 71 - FDO (EBSD) obtida para a condição de um passe. Região de avanço da ferramenta.

Figura 72 - Tamanho de grão para a condição de um passe. Região de avanço da ferramenta.

Figura 73 - Mapa de orientação de grão para a condição de um passe.

Região de retrocesso da ferramenta. 108

Figura 74 - Diferença de orientação dos grãos para a condição de um passe. Região de retrocesso da ferramenta. 109

Figura 75 - Comparação entre as diferenças de orientação dos grãos do cordão de solda com um passe, no lado do avanço e do retrocesso, comparado com o metal de base. 109

Figura 76 - FDO (EBSD) obtida para a condição de um passe. Região de retrocesso da ferramenta. 
Figura 77 - Tamanho de grão para a condição de um passe. Região de retrocesso da ferramenta.

Figura 78 - Comparação entre as porcentagens acumuladas da distribuição dos tamanhos de grão obtidos por EBSD do cordão com um único passe nos lados de avanço e retrocesso e do metal de base.

Figura 79 - Mapa de orientação de grão para a condição de dois passes.

Região de avanço da ferramenta.

Figura 80 - Diferença de orientação dos grãos para a condição de dois passes. Região de avanço da ferramenta.

Figura 81 - FDO (EBSD) obtida para a condição de dois passes. Região de avanço da ferramenta.

Figura 82 - Tamanho de grão para a condição de dois passes. Região de avanço da ferramenta.

Figura 83 - Mapa de orientação de grão para a condição de dois passes.

Região de retrocesso da ferramenta.

Figura 84 - Diferença de orientação dos grãos para a condição de dois passes. Região de retrocesso da ferramenta.

Figura 85 - Comparação entre as diferenças de orientação dos grãos do cordão de solda com dois passes sem reversão, no lado do avanço e do retrocesso, comparado com o metal de base.

Figura 86 - FDO (EBSD) obtida para a condição de dois passes. Região de retrocesso da ferramenta.

Figura 87 - Tamanho de grão para a condição de dois passes. Região de retrocesso da ferramenta.

Figura 88 - Comparação entre as porcentagens acumuladas da distribuição dos tamanhos de grão obtidos por EBSD do cordão com dois passes sem reversão nos lados de avanço e retrocesso e do metal de base. 120

Figura 89 - Mapa de orientação de grão para a condição de dois passes com inversão. Região de avanço da ferramenta.

Figura 90 - Diferença de orientação dos grãos para a condição de dois passes com inversão. Região de avanço da ferramenta. 
Figura 91 - FDO (EBSD) obtida para a condição de dois passes com inversão. Região de avanço da ferramenta.

Figura 92 - Tamanho de grão para a condição de dois passes com inversão. Região de avanço da ferramenta.

Figura 93 - Mapa de orientação de grão para a condição de dois passes com inversão. Região de retrocesso da ferramenta.

Figura 94 - Diferença de orientação dos grãos para a condição de dois passes com inversão. Região de retrocesso da ferramenta.

Figura 95 - Comparação entre as diferenças de orientação dos grãos do cordão de solda com dois passes com reversão, no lado do avanço e do retrocesso, comparado com o metal de base.

Figura 96 - FDO (EBSD) obtida para a condição de dois passes com inversão. Região de retrocesso da ferramenta.

Figura 97 - Tamanho de Grão para a condição de dois passes com inversão. Região de retrocesso da ferramenta.

Figura 98 - Comparação entre as porcentagens acumuladas da distribuição dos tamanhos de grão obtidos por EBSD do cordão com dois passes sem reversão nos lados de avanço e retrocesso e do metal de base. 128

Figura 99 - Diferença de orientação dos grãos para a condição de dois passes com tratamento térmico de recozimento por 8 horas. Região de avanço da ferramenta. 129

Figura 100 - Diferença de orientação dos grãos para a condição de dois passes com tratamento térmico de recozimento por 8 horas. Região de retrocesso da ferramenta. 129

Figura 101 - Tamanho de Grão para a condição de 2 passes sem inversão com tratamento térmico de recozimento por 8 horas. a) Região de avanço da ferramenta b) Região de retrocesso da ferramenta. 130

Figura 102 - Diferença de orientação dos grãos para a condição de 2 passes sem inversão com tratamento térmico de recozimento por 8 horas. a) Região de avanço da ferramenta b) Região de retrocesso da ferramenta. 
Figura 103 - Comparação entre as diferenças de orientação dos grãos do cordão de solda com dois passes sem reversão e com tratamento térmico de solubilização, no lado do avanço e do retrocesso, comparado com o metal de base.

Figura 104 - Curva de energia obtida por calorimetria diferencial em amostra do metal de base(AA 6063T6) após tratamento de solubilização. Velocidade de aquecimento $0,17 \mathrm{Ks}^{-1}$. 134

Figura 105 - Perfis de Microdurezas de cordão de solda SALM de um passe nas condições tratadas CS, S, E e R. As impressões foram realizadas no corte frontal do cordão. Ataque Barker $1,8 \%$.

Figura 106 - Perfis de Microdurezas de cordão de solda SALM de dois passes, sem inversão de rotação no segundo passe, nas condições tratadas CS, S, E e R. As impressões foram realizadas no corte frontal do cordão. 140

Figura 107 - Perfis de Microdurezas de cordão de solda SALM de dois passes, com inversão de rotação no segundo passe, nas condições tratadas CS, S, E e R. As impressões foram realizadas no corte frontal do cordão.

Figura 108 - Perfis de Microdurezas de cordão de solda SALM de um passe nas condições tratadas CS, S, E e R. As impressões foram realizadas na região superior do cordão. 142

Figura 109 - Perfis de Microdurezas de cordão de solda SALM de dois passes, sem inversão de rotação no segundo passe, nas condições tratadas CS, S, E e R. As impressões foram realizadas na região superior do cordão. 143

Figura 110 - Perfis de Microdurezas de cordão de solda SALM de dois passes, com inversão de rotação no segundo passe, nas condições tratadas CS, S, E e R. As impressões foram realizadas na região superior do cordão.

Figura 111 - Perfis de Microdurezas de cordão de solda SALM de um passe nas condições tratadas CS, S, E e R. As impressões foram realizadas na raiz do cordão. 
Figura 112 - Perfis de Microdurezas de cordão de solda SALM de dois passes, sem inversão de rotação no segundo passe, nas condições tratadas CS, S, E e R. As impressões foram realizadas na raiz do cordão.

Figura 113 - Perfis de Microdurezas de cordão de solda SALM de 2 passes, com inversão de rotação no segundo passe, nas condições tratadas CS, S, E e R. As impressões foram realizadas na raiz do cordão. 


\section{LISTA DE TABELAS}

Tabela 1 - Fumos emitidos pelo processo SALM e MIG/MAG ${ }^{(2)}$ xxii

Tabela 2 - Comparativo entre o processo SALM e MIG/MAG na soldagem de perfil de alumínio de $50 \mathrm{~mm}$ de espessura ${ }^{(5)}$.

Tabela 3 - Energias de Ativação $(\mathrm{kJ} / \mathrm{mol})$ para liga Al-Mg-Si, adaptado de Afify et al. ${ }^{(70)}$ e Temperaturas $\left({ }^{\circ} \mathrm{C}\right)$ de precipitação e dissolução de precipitados da liga AA 6005, adaptado das referências ${ }^{(50,71,72)}$. 36

Tabela 4 - Composição química dos corpos de prova..

Tabela 5 - Tempos e Temperaturas de Tratamento Térmico

Tabela 6 - Tabela de Análise de Variância ANOVA. Adaptado de ${ }^{(99,101)}$

Tabela 7 - Caracterização da geometria do cordão de solda na condição como-soldado. Vista Frontal.

Tabela 8 - Razão entre larguras de topo e de raiz tendo como referência as dimensões do cordão com um passe para o cordão de solda na condição como-soldado e vista frontal.

Tabela 9 - Razão entre as áreas da ZTMA no avanço e no retrocesso tendo como referência a área total em cada condição de soldagem para o cordão de solda na condição como-soldado e vista frontal.

Tabela 10 - Medidas dos tamanhos de grão $(\mu \mathrm{m})$. Vista frontal. Condição como soldado.

Tabela 11 - ANOVA para os efeitos condição de soldagem, localização e sua interação para os grãos alongados.

Tabela 12 - ANOVA para os efeitos condição de soldagem, localização e sua interação para os grãos equiaxiais.

Tabela 13 - Medidas de frações recristalizadas secundariamente dos cordões soldados.

Tabela 14 - Medidas dos tamanhos de grão $(\mu \mathrm{m})$. Vista frontal. Condição

Solubilizado. 93

Tabela 15 - Medidas dos tamanhos de grão $(\mu \mathrm{m})$. Vista frontal. Condição

Solubilizado e Envelhecido. 
Tabela 16 - Medidas dos tamanhos de grão $(\mu \mathrm{m})$. Vista frontal. Condição Recozido por 2 horas.

Tabela 17 - Medidas dos tamanhos de grão $(\mu \mathrm{m})$. Vista frontal. Condição

Recozido por 8 horas.

Tabela 18 - Cálculo de ANOVA para os fatores tratamento térmico, condição de soldagem do cordão e localização.

Tabela 19 - Tabela de ANOVA para os fatores Tratamento Térmico, Condições de Soldagem e Localização, para grãos alongados na ZTMA.

Tabela 20 - Dados de textura para as diferentes condições de soldagem sem tratamento térmico e com tratamento de recozimento por 8 horas. 132

Tabela 21 - Temperaturas de dissolução para diferentes velocidades de aquecimento. Cordão com 1 passe na condição como soldado. 136

Tabela 22 - Energia de ativação calculada através da inclinação da reta obtida por interpolação linear. Uma estimativa do erro da interpolação também é fornecida. Cordão com 1 passe na condição como soldado. 136

Tabela 23 - Temperaturas de dissolução para diferentes velocidades de aquecimento. Cordão com 2 passes sem inversão, na condição como soldado.

Tabela 24 - Energia de ativação calculada através da inclinação da reta obtida por interpolação linear. Uma estimativa do erro da interpolação também é fornecida. Cordão com 2 passes sem inversão, na condição como soldado.

Tabela 25 - Temperaturas de dissolução para diferentes velocidades de aquecimento. Cordão com 2 passes com inversão, na condição como soldado. 138

Tabela 26 - Energia de ativação calculada através da inclinação da reta obtida por interpolação linear. Uma estimativa do erro da interpolação também é fornecida. Cordão com 2 passes com inversão, na condição como soldado. 


\section{LISTA DE ABREVIATURAS E SIGLAS}

$\begin{array}{ll}\text { 6XXX } & \text { Ligas de alumínio da série } 6000 \text { também denominada Al-Mg-Si } \\ \text { ANOM } & \text { Analysis of Medians } \\ \text { ANOVA } & \text { Analysis of Variance } \\ \text { EBSD } & \text { Electron Backscattered Diffraction } \\ \text { ECAE } & \text { Equal Channel Angular Extrusion } \\ \text { ECAP } & \text { Equal Channel Angular Pressing } \\ \text { EDE } & \text { Energia de Falha de Empilhamento } \\ \text { FDO } & \text { Função Distribuição De Orientação } \\ \text { FSW } & \text { Friction Stir Welding } \\ \text { GP } & \text { Guinier-Preston } \\ \text { iSTIR } & \text { Modelo Térmico E Analítico Para O Processo SALM } \\ \text { LASER } & \text { Light Amplification by Stimulated Emission of Radiation } \\ \text { MAG } & \text { Metal Active Gas } \\ \text { MIG } & \text { Metal Inert Gas } \\ \text { ODF } & \text { Orientation Distribution Function } \\ \text { RPM } & \text { Rotações Por Minuto } \\ \text { SALM } & \text { Soldagem por Atrito Linear com Mistura } \\ \text { SPD } & \text { Severe Plastic Deformation } \\ & \text { Tratamento térmico de liga de alumínio: Solubilizado e } \\ \text { T4 } & \text { envelhecido naturalmente até uma condição estável } \\ & \text { Tratamento térmico de liga de alumínio: Solubilizado e } \\ \text { T6 } & \text { envelhecido artificialmente } \\ \text { Triflat } & \text { Modelo de ferramenta patenteado para o processo SALM } \\ \text { TWI } & \text { The Welding Institute } \\ \text { ZAC } & \text { Zona Afetada pelo Calor } \\ \text { ZTMA } & \text { Zona Termomecânicamente Afetada } \\ & \end{array}$




\section{LISTA DE SÍMBOLOS}

Símbolo

Descrição

Unidade

$A$ e $B \quad$ produtos de solubilidade

$A^{\prime} \quad$ constante do material

$\mu \quad$ coeficiente de atrito

b constante do material

c constante do material

C concentração dos componentes dos precipitados

(\% em peso)

tamanho de grão

(m)

tamanho de subgrão

(m)

fração volumétrica disponível para dissolução

tamanho de grão final

(m)

tamanho de grão inicial

(m)

Dureza da fase $n$

$(\mathrm{Hv})$

constante cinética

constante do material

constante do material

$m$

número de interceptos por círculo teste

$\left(\mathrm{m}^{-1}\right)$

pressão da ferramenta

$\mathrm{Pa}$

potência transmitida para o cordão

(W)

energia de ativação

$\left(\mathrm{J} \mathrm{mol}^{-1}\right)$

constante do gás 8,314

$\left(\mathrm{J} \mathrm{mol}^{-1} \mathrm{~K}^{-1}\right)$

rotação da ferramenta

(rpm)

raio da fonte de calor

velocidade de aquecimento

temperatura

(K)

tempo

temperatura

instante inicial

temperaturas abaixo da solubilização e acima da

$T_{2}$

temperatura de tratamento com tempo comum para o (K)

início da recristalização e precipitação

$T_{c} \quad$ temperatura mínima

$T_{f}$

temperatura de fusão

$T_{s}$

temperatura de solubilização 
$\beta^{\prime}$

$\beta^{\prime \prime}$

$\lambda$

$\rho$

$\sigma$

E

$\overline{T G}$

velocidade da fonte de calor

$\left(\mathrm{ms}^{-1}\right)$

fração volumétrica da fase $n$

fração volumétrica de recristalização secundária

velocidade de translação da ferramenta

distância no eixo $x$

distância no eixo y

parâmetro Zener - Hollomon

$\left(s^{-1}\right)$

Precipitado $\mathrm{Mg}_{2} \mathrm{Si}$ para ligas Al-Mg-Si

Precipitado semi-coerente tipo bastonete para ligas Al-

$\mathrm{Mg}-\mathrm{Si}$

Precipitado coerente tipo agulha para ligas Al-Mg-Si

condutividade térmica

densidade de discordâncias

desvio padrão

taxa de deformação

tamanho de grão médio

(m) 


\section{JUSTIFICATIVA}

Invenções podem ser classificadas genericamente em duas categorias: aquelas que procuram soluções e aquelas que fornecem soluções. A soldagem por atrito linear com mistura (SALM), conhecida também por seu nome em inglês friction stir welding (FSW), foi inventada numa época que a comunidade envolvida com junção de materiais procurava uma solução para soldar ligas de alumínio de alta resistência, obtendo juntas com propriedades mecânicas superiores ${ }^{(1,2)}$.

A soldagem pelo processo SALM permite a junção de materiais dissimilares e não dissimilares de ligas de alumínio, aço, níquel, cobre e titânio. Com o SALM as juntas obtidas são de melhor qualidade quando comparadas com as obtidas por processos de soldagem convencional por arco. As principais características positivas destas juntas são a alta resistência, maior vida em fadiga, menor distorção, menor tensão residual, menor susceptibilidade à corrosão e menor quantidade de defeitos volumétricos ${ }^{(2,3)}$.

Além das vantagens na qualidade da junta, o SALM tem outras vantagens relacionadas com o meio ambiente ${ }^{(4)}$. Arbegast ${ }^{(2)}$ estimou que se $10 \%$ do mercado americano de junção fosse trocado pelo processo SALM, iria ocorrer uma redução anual de energia da ordem de $1,35 \times 10^{16} \mathrm{~J}$ e uma redução anual de $227 \times 10^{6} \mathrm{Kg}$ de emissão de gases relacionados com o efeito estufa. As emissões de fumos nocivos a saúde também são reduzidos neste processo, a tabela 1 apresenta um comparativo das emissões para o SALM e a soldagem MIG/MAG ${ }^{(5)}$. 
Tabela 1 - Fumos emitidos pelo processo SALM e MIG/MAG ${ }^{(5)}$

\begin{tabular}{lcccc}
\hline Processo & $\mathrm{Cr}\left(\mathrm{mg} / \mathrm{mm}^{3}\right)$ & $\mathrm{Cu}\left(\mathrm{mg} / \mathrm{mm}^{3}\right)$ & $\mathrm{Mn}\left(\mathrm{mg} / \mathrm{mm}^{3}\right)$ & $\mathrm{Cr}^{6+}\left(\mathrm{mg} / \mathrm{mm}^{3}\right)$ \\
\hline MIG / MAG & 0,25 & 0,11 & 1,88 & 0,02 \\
SALM & $<0,03$ & $<0,03$ & $<0,02$ & $<0,01$ \\
\hline
\end{tabular}

A indústria aeroespacial mostrou grande interesse na sua utilização ${ }^{(6,7)}$ e, após a sua invenção, o desenvolvimento tecnológico da ferramenta foi muito mais expressivo do que a pesquisa fundamental no processo ${ }^{(1)}$.

Mishra ${ }^{(1)}$ identifica algumas áreas como importantes para um conhecimento mais profundo do processo. Entre elas estão a evolução microestrutural em condições de alta taxa de deformação da junta e a influência do processo nas propriedades finais da mesma para ligas de alumínio endurecíveis por tratamento térmico.

A microestrutura obtida pelo SALM apresenta características únicas e é importante separar a influência destas características nas propriedades finais da junta.

O aprofundamento nestas áreas permite compreender os fenômenos que ocorrem durante o processo SALM e nas juntas soldadas quando submetidas a tratamentos térmicos posteriores.

Ainda, a utilização de múltiplos passes e tratamentos térmicos posteriores podem ser métodos de retrabalho do cordão em casos de defeitos volumétricos e propriedades mecânicas não desejadas ${ }^{(8)}$.

Concluindo, estudos que avaliem a evolução microestrutural da junta, o efeito de diferentes deformações oriundas do processo e o efeito do tratamento térmico permitem um maior domínio sobre o processo de soldagem garantindo a manufatura de produtos com padrões de qualidade elevados. 


\section{SUMÁRIO}

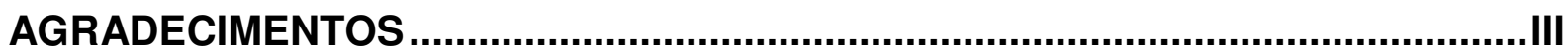

RESUMO

ABSTRACT

LISTA DE ILUSTRAÇÕES .............................................................................. VI

LISTA DE TABELAS

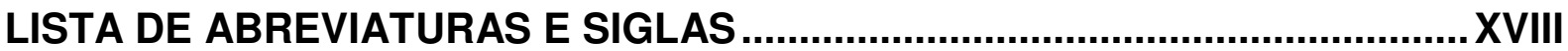

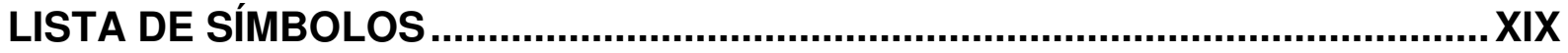

JUSTIFICATIVA

SUMÁRIO

1 INTRODUÇÃO

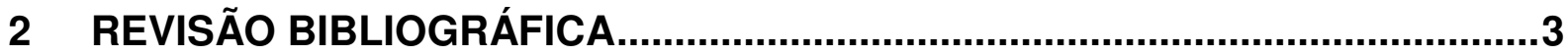

2.1 Processo de Soldagem por Atrito linear com Mistura (SALM) de Ligas

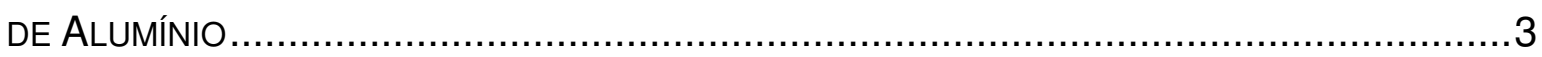

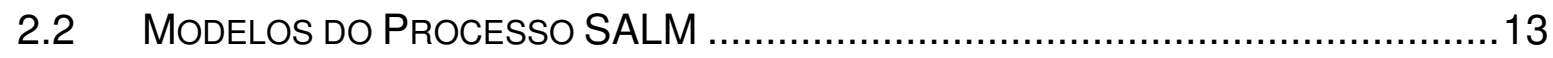

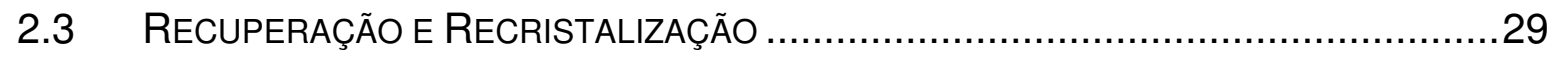

2.4 Crescimento de Grãos e ReCRISTALIZAÇÃo SeCundáRIA ……....................31

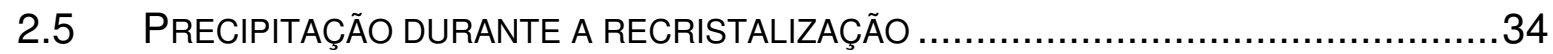

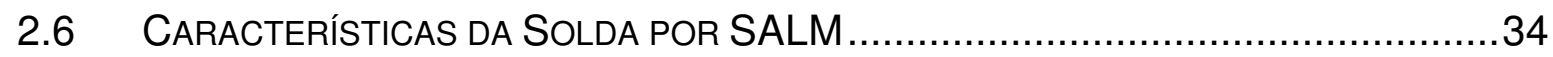

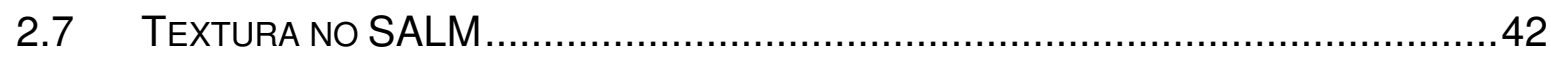

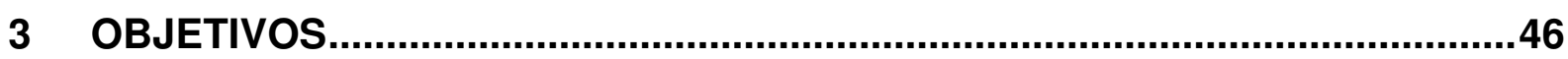

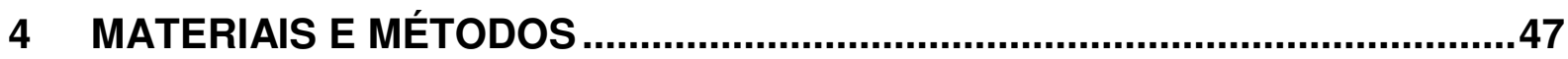

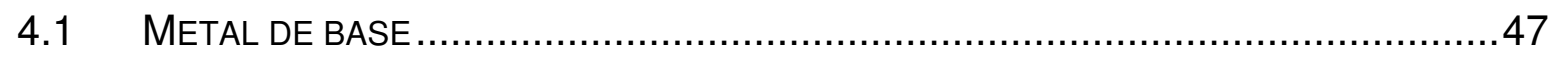

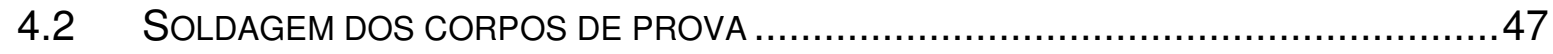

4.3 PREPARAÇÃO DAS AMOSTRAS PARA MICROSCÓPIO ÓTICO …............................49

4.4 PREPARAÇÃO DAS AMOSTRAS PARA CALORIMETRIA DIFERENCIAL.......................50

4.5 PREPARAÇÃO DAS AMOSTRAS PARA EBSD E MEV ...................................5

4.6 TRATAMENTO TÉRMICO NOS CORDÕES (1 PASSE E 2 PASSES) ….......................51 


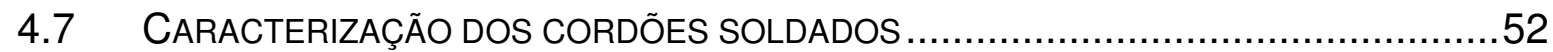

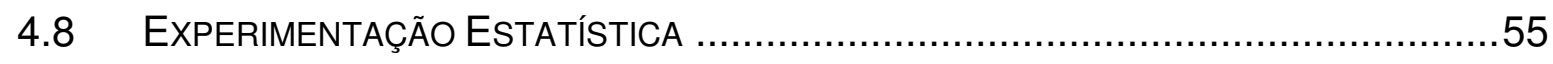

5 RESULTADOS E DISCUSSÃO ................................................................63

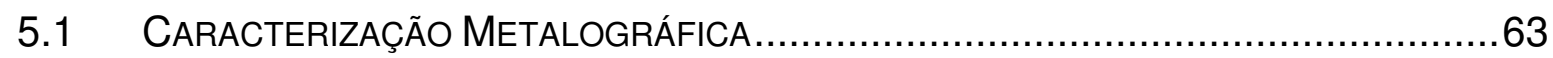

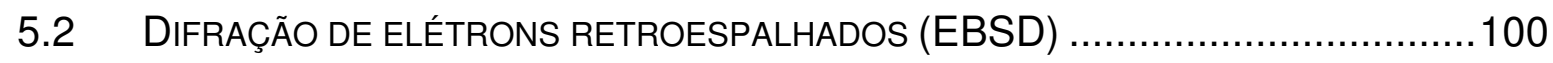

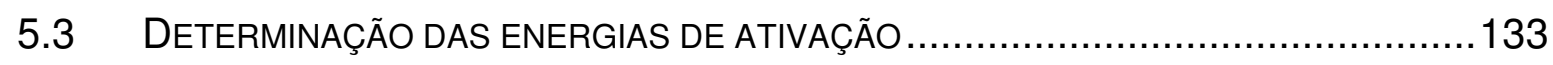

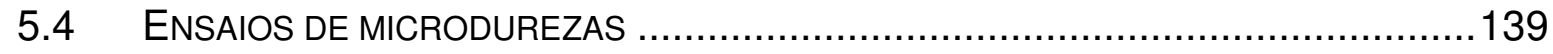

6 CONCLUSÕES ....................................................................................149

7 SUGESTÕES DE TRABALHOS FUTUROS ............................................153

8 REFERÊNCIAS BIBLIOGRÁFICAS........................................................154 


\section{INTRODUÇÃO}

O processo de soldagem por atrito, denominado soldagem por atrito linear com mistura (SALM), ou em inglês friction stir welding (FSW), foi concebido em 1991 pelo The Welding Institute (TWI) na Inglaterra. A aplicação deste processo na soldagem de alumínio na indústria aeronáutica da Europa, América do Norte e América do Sul é considerada como um diferencial técnico competitivo.

As vantagens resultam do fato que o SALM, como todos os outros processos de soldagem por atrito, é realizado na fase sólida, abaixo do ponto de fusão do material a ser unido. O processo, por ser automatizado, também permite ser controlado com precisão, tendo uma boa repetibilidade na qualidade da junta.

As ligas de alumínio, endurecíveis por precipitação, muito utilizadas na indústria aeronáutica, sofrem uma perda das propriedades mecânicas na região da solda devido ao ciclo térmico que a região é submetida, além de possíveis tratamentos térmicos posteriores. Nesta região ocorrem simultaneamente diversas transformações de fase, como a recristalização, crescimento de grão e crescimento e solubilização de precipitados.

As propriedades mecânicas resultantes da junta são importantes na determinação da eficiência da junta, que é uma característica de projeto na construção mecânica. A eficiência da junta soldada é reduzida com o amolecimento da região central do cordão, que limita a utilização de materiais endurecíveis por precipitação e pode inviabilizar a utilização do próprio processo SALM.

Os tratamentos térmicos posteriores são utilizados para melhorar esta eficiência, porém apresentam um custo elevado de manufatura e controle.

Assim, para a aplicação deste processo na fabricação de juntas de alta eficiência em ligas endurecíveis por precipitação é preciso, além de obter um cordão livre de 
defeitos volumétricos e de interface, determinar as condições de soldagem para minimizar as transformações que prejudicam as propriedades mecânicas da junta soldada. 


\section{REVISÃo BIBLIOGRÁFICA}

\subsection{Processo de Soldagem por Atrito Linear com Mistura (SALM) de Ligas de Alumínio}

A soldagem por atrito ocorre no estado sólido e a fonte de energia é de natureza mecânica. No processo desenvolvido nas décadas de 1950 e 1960, o aquecimento para a ligação entre as partes é obtido através da rotação de uma das partes, mantida sob pressão contra a outra. Como não ocorre a fusão do metal, defeitos associados à fusão e à solidificação, como por exemplo, poros e respingos, não estão presentes. Esta soldagem por atrito rotacional, apesar de ser capaz de soldar diversos materiais e, materiais dissimilares, está limitada aos tipos de junta de topo, planas ou angulares, que devem ser perpendiculares e concêntricas com o eixo de rotação ${ }^{(9)}$. A figura 1 ilustra este processo de soldagem.

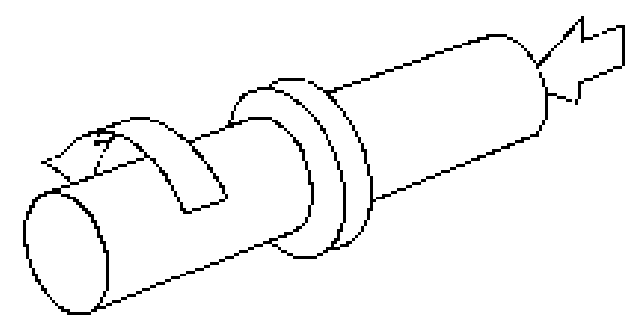

Figura 1 - Soldagem por atrito rotacional ${ }^{(10)}$.

No SALM uma ferramenta cilíndrica rotatória é introduzida na junta de topo, ou sobreposta, entre duas peças a uma determinada profundidade. A ferramenta é então movida ao longo desta junta. O processo é caracterizado pelo calor gerado através do atrito interno do material e o atrito entre a superfície da ferramenta em rotação e a superfície do material da junta, pela mistura do material, deformação 
plástica oriunda da ferramenta em rotação e do avanço linear. A soldagem também é realizada no estado sólido com baixa distorção geométrica e, com propriedades mecânicas superiores à soldagem por $\operatorname{arco}\left(11,{ }^{12}\right)$. A figura 2 ilustra esquematicamente este tipo de processo.

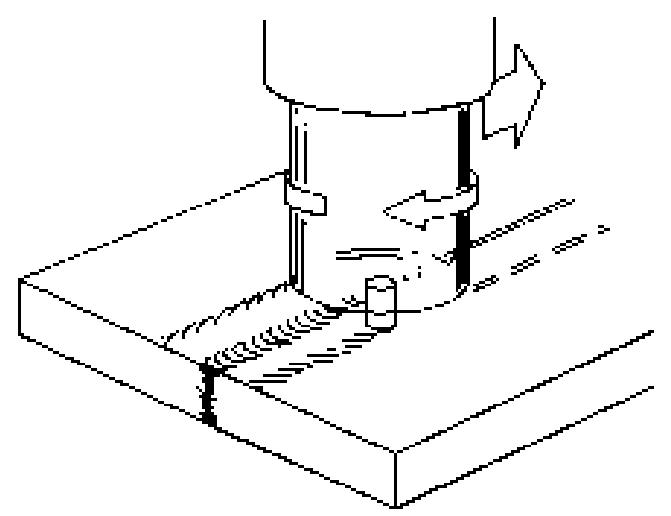

Figura 2 - Processo de soldagem por atrito linear com mistura ${ }^{(10)}$.

Atualmente, para a soldagem de ligas de alumínio, o processo por arco é o mais utilizado, devido a sua flexibilidade e baixo custo além da boa soldabilidade de muitas das ligas de alumínio. Nas indústrias aeronáuticas e automobilísticas são freqüentes também as soldagens de alumínio por TIG, MIG, plasma, feixe de elétrons, laser, e por difusão $(12,13,14,15)$. A escolha de processos menos convencionais está associada à soldabilidade das ligas empregadas. Em particular, as ligas das séries 2000 e 7000 utilizadas em muitas das aplicações nestas indústrias possuem uma soldabilidade muito ruim, caracterizada pela presença de trincas de solidificação.

Devido ao problema de soldabilidade de algumas ligas de alumínio (séries 2000 e 7000), procura-se desenvolver ligas com soldabilidade melhorada ou processos com fontes de calor de baixa potência, eficientes e concentradas, melhorando assim, o formato do cordão, minimizando a zona afetada pelo calor e reduzindo tanto as distorções como a presença de trinca de solidificação nestas ligas ${ }^{(12)}$. O processo 
SALM tem todas estas características, ou seja, uma fonte calor de eficiência térmica elevada em toda área da deformação plástica, além de soldar no estado sólido.

O alumínio tem algumas características físicas e químicas que devem ser consideradas em todos os processos de soldagem. Estas características tornam os processos de soldagem, por fusão de alumínio e suas ligas, complexos e com maior probabilidade de falhas, quando comparados a outros materiais ou ligas metálicas. $\mathrm{O}$ alumínio forma uma camada de óxidos superficial, que tem um ponto de fusão próximo à $2050^{\circ} \mathrm{C}$, muito acima do ponto de fusão da liga de alumínio. O processo de soldagem deve ser capaz de quebrar esta camada e removê-la continuamente, para evitar defeitos, como por exemplo, a falta de fusão. Esta camada de óxidos atua como um isolante elétrico, dificultando, na soldagem com fonte de calor de energia elétrica, a abertura do arco e a fusão do alumínio. Nos processos com fusão esta camada de característica porosa pode absorver substâncias que contém hidrogênio, introduzindo-o na poça de fusão. Este fato, somado à grande solubilidade do hidrogênio no estado líquido do alumínio, pode promover a porosidade do cordão de solda. Assim, são necessárias a preparação e limpeza da superfície das juntas, para a soldagem por fusão. Devido à alta condutividade térmica do alumínio, a soldagem é muito sensível a variações na fonte de calor durante o processo, podendo levar a variações no volume de material fundido e na penetração do cordão de solda. O alumínio tem uma taxa de contração de, aproximadamente, $6 \%$ durante a solidificação, necessitando de um balanceamento da seqüência de soldagem para reduzir a distorção da peça que está sendo soldada. As tensões residuais da peça associadas a o coeficiente de dilatação térmica linear tornam o alumínio suscetível a trincas de solidificação ${ }^{(13,15)}$. 
As características do SALM não o tornam suscetível aos defeitos oriundos da camada de óxidos, como nos processos com fusão. A baixa potência obtida a uma taxa constante torna o processo homogêneo, com baixas distorções.

O ciclo térmico da zona afetada pelo calor, para ligas de alumínio endurecíveis por precipitação, causa a degradação de suas propriedades mecânicas devido a modificações microestruturais ${ }^{(13,15)}$. Obtém-se na soldagem uma região, adjacente ao cordão, solubilizada e com crescimento de grão e, após esta, uma região superenvelhecida, conforme a curva de resfriamento e a reação de formação dos precipitados. O calor utilizado para a soldagem é responsável pela degradação da microestrutura ${ }^{(15)}$. A zona afetada pelo calor no SALM é de dimensão próxima ao diâmetro da ferramenta, sendo assim relevante para a análise.

As vantagens do processo SALM estão relacionadas com a baixa energia utilizada para soldagem e com a ausência de fusão. A freqüência de defeitos inferior à soldagem por arco, além de apresentar a facilidade de preparação das juntas, ausência da necessidade de gases de proteção e metais de adição ${ }^{(7)}$. A inspeção da solda pode também ser diminuída. Todas estas vantagens reduzem, consideravelmente, o custo de soldagem ${ }^{(7)}$. A tabela 2 apresenta um comparativo de custos entre o processo SALM e o processo MIG/MAG na soldagem de um perfil de uma liga de alumínio de $50 \mathrm{~mm}$ de espessura. Esta tabela não considera a complexidade de fixação das peças, como também, os custos de licenciamento e amortização do equipamento. 
Tabela 2 - Comparativo entre o processo SALM e MIG/MAG na soldagem de perfil de alumínio de $50 \mathrm{~mm}$ de espessura ${ }^{(5)}$.

\begin{tabular}{lcc}
\hline Categoria & SALM & MIG/MAG \\
\hline Tempo de Soldagem (s) & 145 & 442 \\
Tempo de Movimentação e Fixação (s) & 485 & 191 \\
Tempo de Movimentação Cabeçotes (s) & 145 & 313 \\
Remoção de Óxidos (s) & 0 & 374 \\
Equipamentos de Segurança (s) & 0 & 120 \\
Tempo Total de Preparação (s) & $\mathbf{7 7 5}$ & $\mathbf{1 4 4 0}$ \\
Velocidade de Soldagem (m/s) & 33,3 & 12,5 \\
Custos de Investimento (US\$) & 400 & 200 \\
Comprimento da solda (m) & 2000 & 2000 \\
Custos fixos por hora & & \\
Aluguel (US\$) & 13 & 13 \\
Amortização em 4 anos (US\$) & 52 & 26 \\
Custos Variáveis por hora & & 30 \\
Mão de Obra (US\$) & 30 & 3 \\
Energia & 1 & 2 \\
Consumíveis & - & 2 \\
Gases & - & $\mathbf{7 6}$ \\
Custo Total por hora (US\$) & $\mathbf{9 6}$ & $\mathbf{1 3 , 4 7}$ \\
Cordão por hora (m) & $\mathbf{1 1 , 4 0}$ & \\
Custo por comprimento soldado (US\$) & $\mathbf{8 , 3 8}$ & \\
\hline
\end{tabular}

Este processo pode soldar ligas de alumínio da série 2000 (Al-Cu) e 7000 (Al-Zn), que eram anteriormente consideradas não soldáveis por fusão e que possuem uma grande aplicação em estruturas aeronáuticas. A vida, em fadiga, desta solda é comparável à junção de placas de alumínio com rebites, sendo superior ao processo MIG e próximas ao metal de base ${ }^{(12)}$. A figura 3 ilustra os resultados de testes de fadiga para ligas de alumínio soldadas por SALM. 
a)

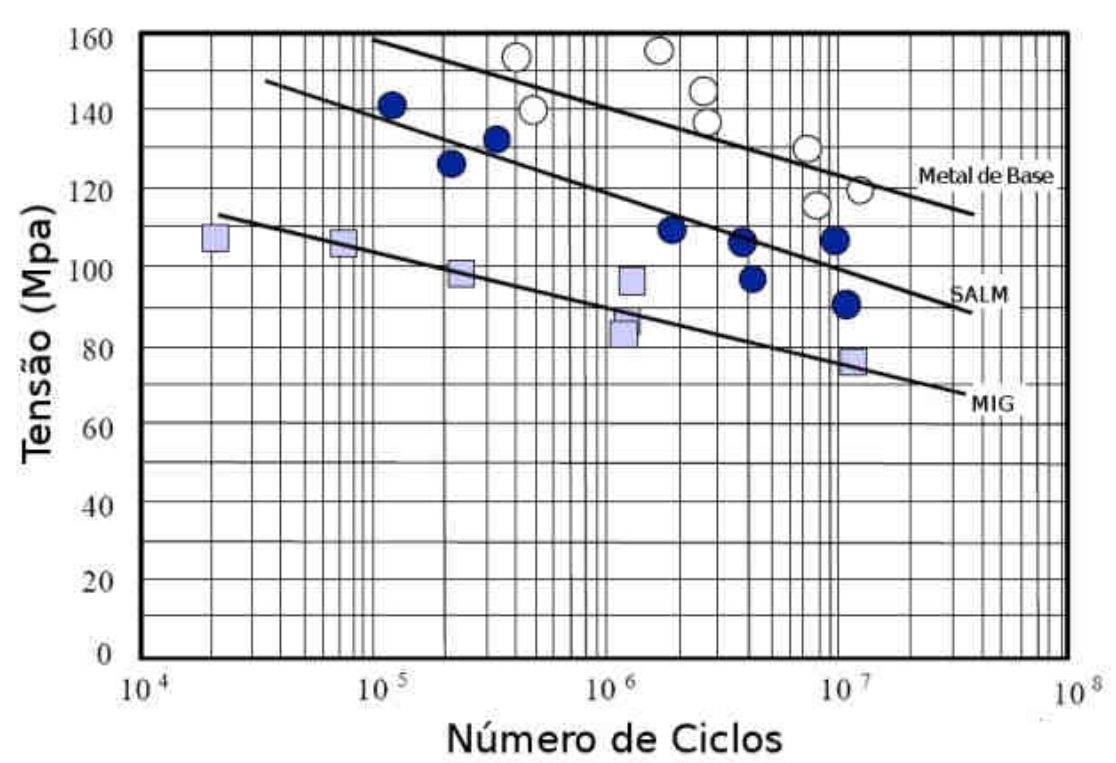

b)

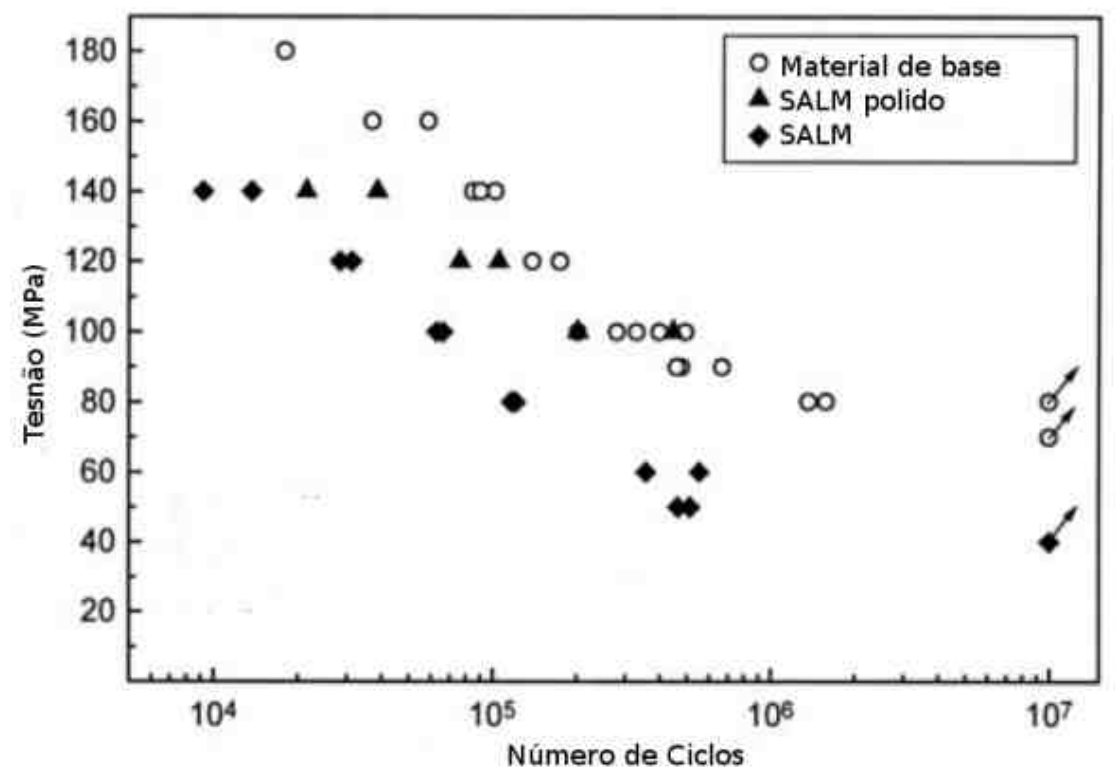

Figura 3 - Ensaio de Fadiga. Número de ciclos até a ruptura para alumínio série 6000 . a) Comparação MIG, SALM e Material de Base, b) Comparação SALM, Cordão de solda obtido por SALM polido e Material de Base ${ }^{(16,17)}$.

O SALM, quando comparado com outros processos, é considerado robusto e aplicável em produções seriadas ${ }^{(18)}$. Outras vantagens são: ausência de porosidade e respingos, soldagem em todas as posições, alta eficiência de energia ${ }^{(19)}$. Devido às vantagens do SALM, este está sendo desenvolvido nas indústrias aeronáutica, espacial e automobilística, sendo considerado, em alguns casos, um 
substituto para a soldagem por arco, plasma ou feixe de elétrons $(7,12,14,20)$. Aplicações em aços e, em outros materiais também estão sendo desenvolvidas ${ }^{(21,}$ 22, 23, 24, 25). As principais desvantagens do processo são: a necessidade de fixação rígida, o furo remanescente após a soldagem, velocidade moderadamente inferior a alguns processos por fusão e a necessidade de placas isolantes ${ }^{(19,26)}$. A velocidade de soldagem é comparável aos processos de soldagem por LASER, como ilustra a figura 4.

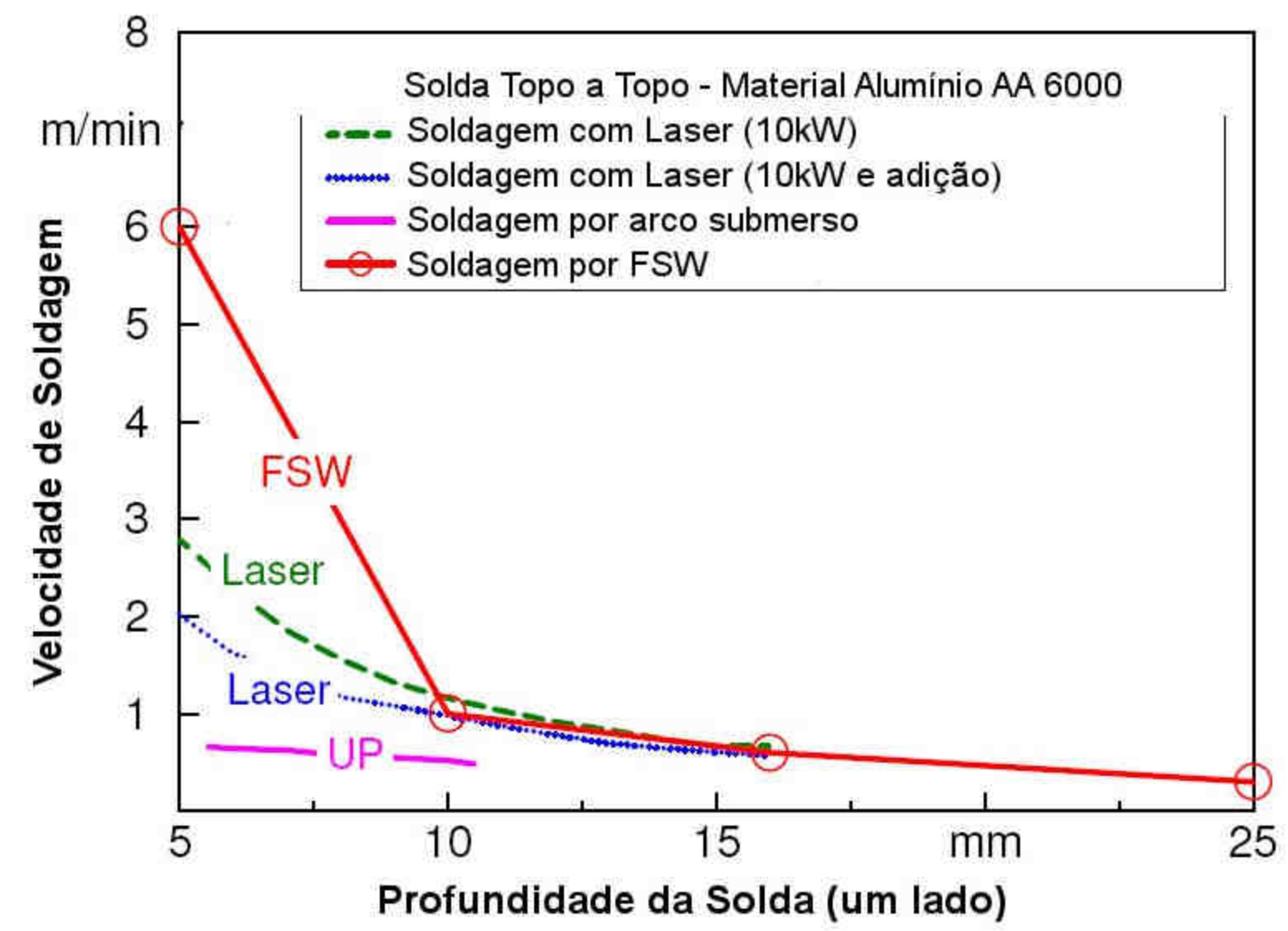

Figura 4 - Comparativo de três processos para a soldagem de juntas topo a topo de ligas de alumínio da série AA $6000^{(27)}$.

O equipamento convencional consiste de uma estrutura rígida, com um cabeçote para uma ferramenta rotativa que se desloca sobre a junta a ser soldada. As peças a serem soldadas são fixadas sob pressão ${ }^{(7)}$. A figura 5 ilustra o equipamento e sua operação. 

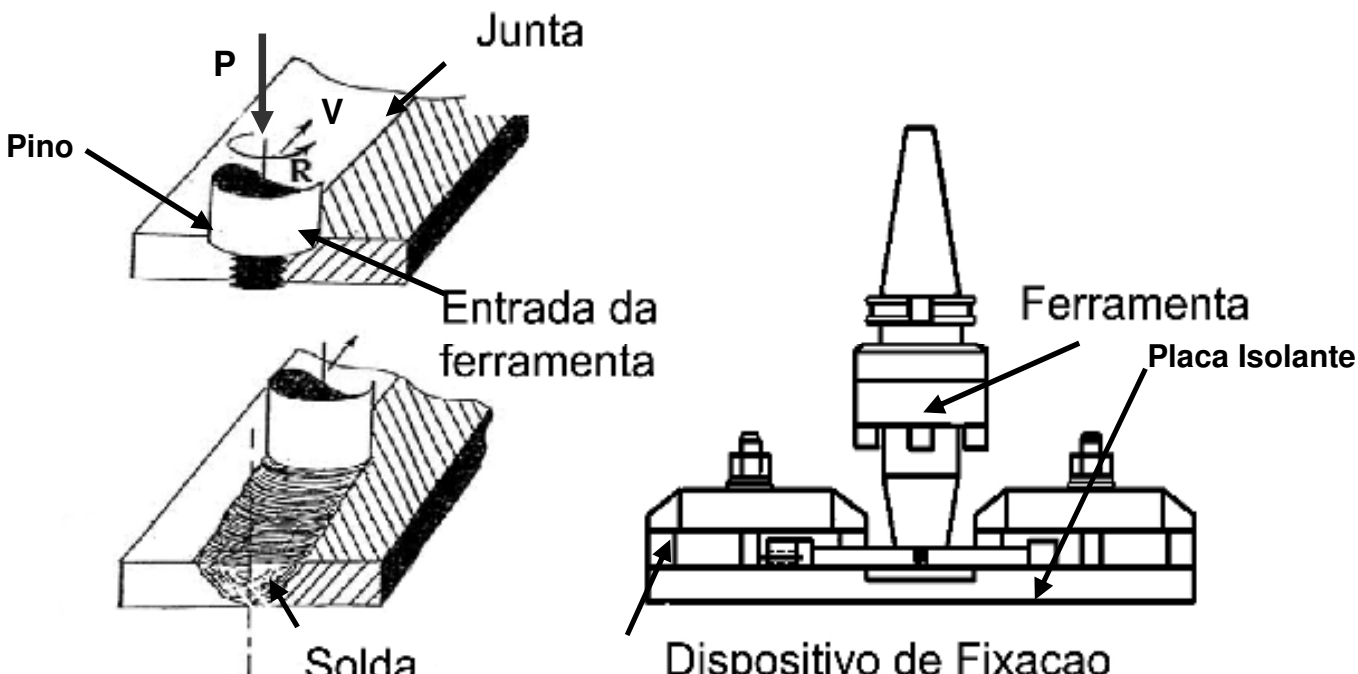

Figura 5 - Esquema do processo SALM. Adaptado das referências ${ }^{(28,29)}$.

A operação do equipamento é automatizada, não necessitando de um soldador certificado e sim de um operador qualificado ${ }^{(30)}$. As variáveis de operação são: velocidade de avanço da ferramenta $(V)$, rotação da ferramenta $(R)$, geometria da ferramenta e ombro (Pino, Rosca ou Pino com Anéis), pressão da ferramenta $(P)$, temperatura inicial do metal de base. A figura 6 ilustra os três tipos básicos de ferramentas. As ferramentas são responsáveis pela mistura do material e o ombro delas por parte da geração de calor por atrito. As primeiras ferramentas utilizadas no processo foram as com rosca, como ilustrado na figura $6 \mathrm{a}$. Com a necessidade de melhorar as propriedades das juntas soldadas e aumentar a penetração surgiram ferramentas mais complexas ilustradas nas figuras $6 \mathrm{~b}$ e $6 \mathrm{c}^{(31)}$. Um desenvolvimento avançado do SALM é a utilização de uma ferramenta dupla com atuação em ambos os lados do material ${ }^{(32)}$.

A técnica para o desenvolvimento de ferramentas, seus desenhos e materiais estão protegidos por patentes, ou são tratados como segredos industriais ${ }^{(16)}$. 


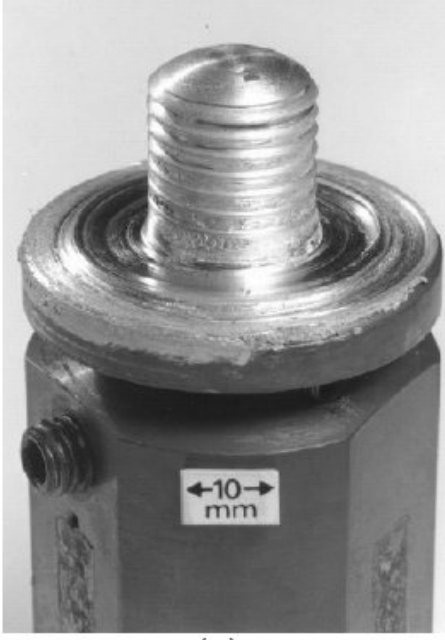

(a)

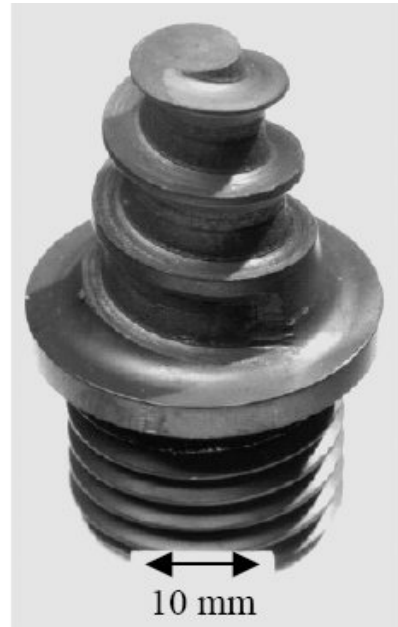

(b)

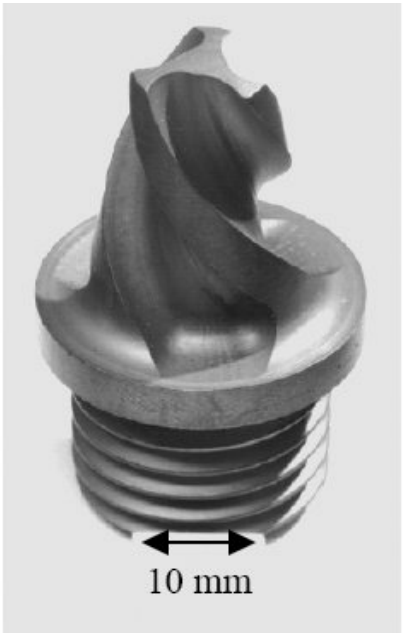

(c)

Figura 6 - Exemplos de ferramentas e pinos: (a) ferramenta convencional, (b) pino tipo Whorl ${ }^{\mathrm{TM}}$ e (c) pino MX Triflute ${ }^{\mathrm{TM}}$, desenvolvidas pelo TWI ${ }^{(33)}$.

As figuras 7 a 9 são ilustrações de diferentes tipos de processos SALM, mostrando a sua versatilidade de uso na indústria. A figura 7 ilustra o processo duplo onde duas ferramentas soldam um perfil em ambos os lados, permitindo a soldagem de peças mais espessas e de geometrias mais complexas.

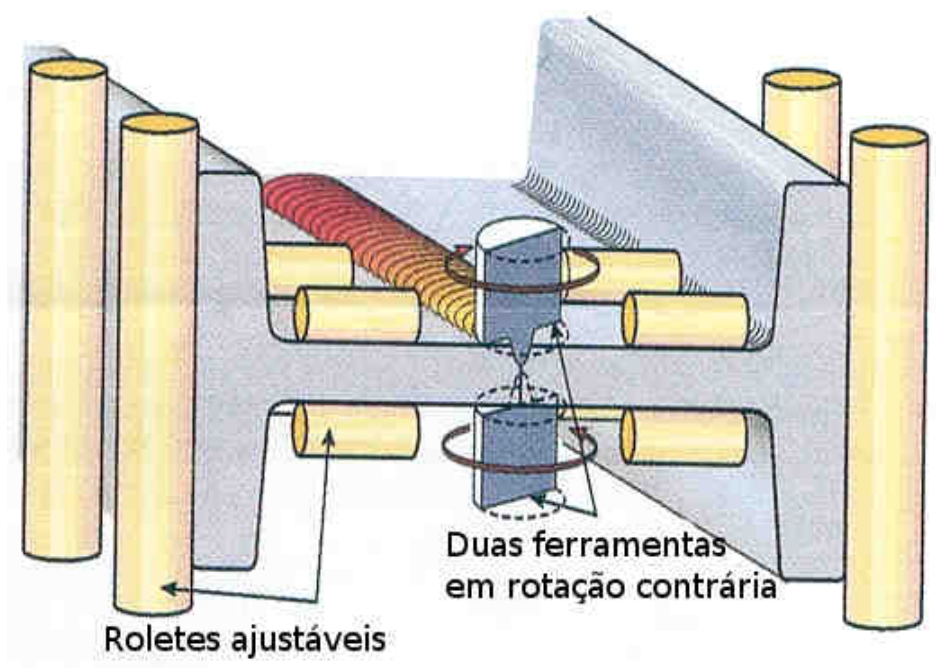

Figura 7 - SALM duplo. Realizado com duas ferramentas em ambos os lados de um perfil típico ${ }^{(34)}$.

O processo SALM também pode ser aplicado na fabricação de tubos com costura, onde as propriedades mecânicas do cordão permitem a fabricação de tubos de ligas não ferrosas de qualidade superior como está ilustrado na figura 8. 


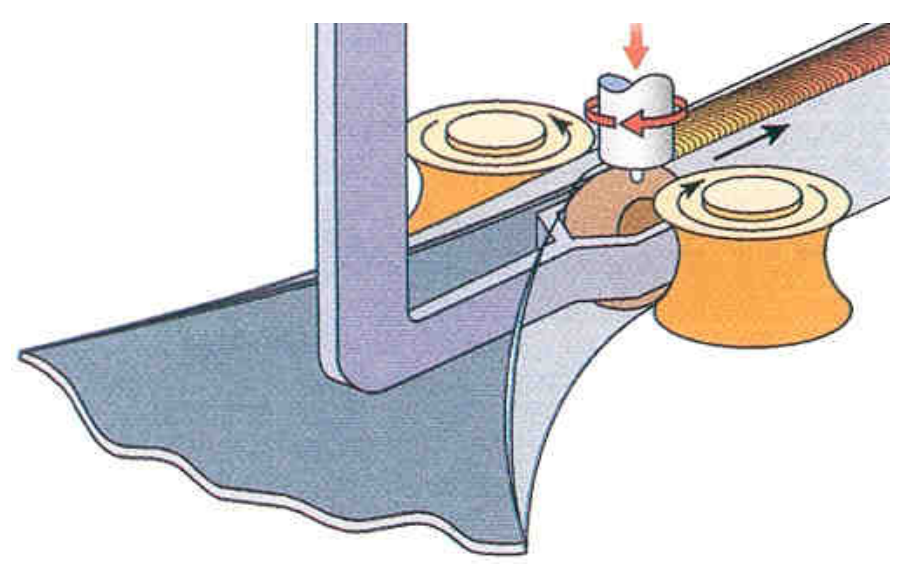

Figura 8 - SALM na fabricação de tubos não ferrosos ${ }^{(34)}$.

A soldagem de ligas com alto ponto de fusão, ou que necessitam de adição para melhorar as propriedades finais da junta podem ser realizadas com processos híbridos. Um processo conhecido é o SALM assistido por LASER ou plasma, que aquece o material na frente da ferramenta. Este calor adicionado por um processo secundário somado ao calor gerado pelo atrito do ombro da ferramenta eleva a temperatura do material permitindo a sua mistura ${ }^{(35,36)}$. A figura 9 ilustra este processo onde ocorre a adição de um terceiro metal na soldagem.

a)

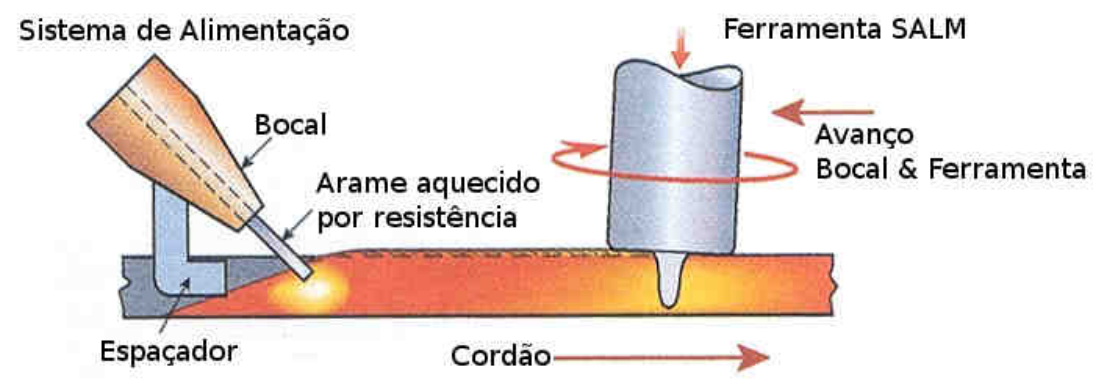

b)

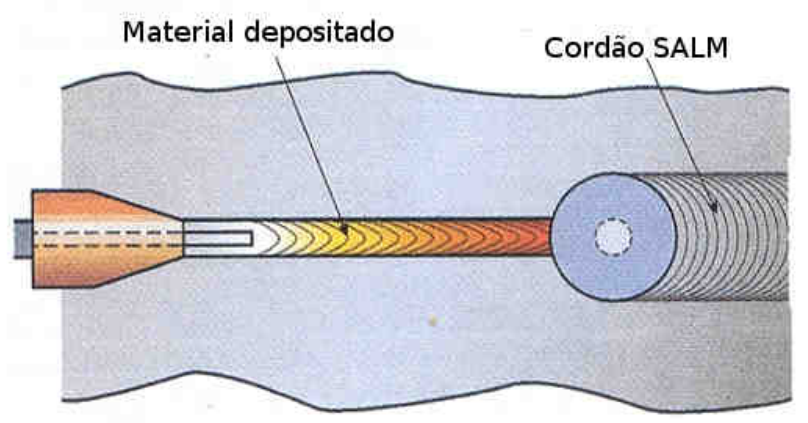

Figura 9 - SALM Híbrido: (a) Vista lateral e (b) Vista superior ${ }^{(34)}$. 


\subsection{Modelos do Processo SALM}

O conhecimento sobre o processo SALM ainda não é completo e os desenvolvimentos foram realizados, geralmente, através do empirismo ${ }^{(1,37,38)}$.

O modelamento fenomenológico de um processo oferece redução de tempo e de custos nos programas de desenvolvimento. Os esforços para o conhecimento teórico do processo SALM, como modelos e simulações, são muito limitados devido à sua complexidade, que envolve: junção termomecânica, aumento de temperatura, grandes deformações plásticas, superfície de contato e coeficiente de atrito ${ }^{(39)}$.

A chave para o modelamento é coincidir a complexidade das soluções com o nível de qualidade desejado das respostas do modelo. Assim, modelos empíricos e semiempíricos, relativamente, simples podem ser utilizados, fornecendo uma ferramenta de desenvolvimento rápida e flexível ${ }^{(38)}$. Modelos complexos do processo, como modelos fenomenológicos, também são úteis para desenvolver esta aplicação em outros materiais e aperfeiçoar a tecnologia existente ${ }^{(37)}$.

Os modelos revistos $(38,39,40,41,42,43,44,45)$ dão ênfase ao fenômeno térmico no processo de soldagem, pois este é de grande importância para as propriedades mecânicas e microestruturais resultantes na solda. Os modelos de transferência de calor são, normalmente, fenomenológicos e os que predizem a dureza ou a microestrutura são empíricos, ou semi-empíricos. Os modelos seguintes se destacam por sua aplicabilidade e abrangência em SALM.

McClure ${ }^{(45)}$ propõe um modelo térmico baseado na equação de Rosenthal, que descreve uma distribuição de temperatura máxima de um meio semi-infinito, na temperatura $T_{0}$, em função da distância. Neste modelo o aquecimento (q) é gerado 
somente pelo atrito da ferramenta na peça $(\mu)$, movendo-se a uma velocidade constante de rotação (v) e de translação $(\omega)$. Ainda segundo McClure ${ }^{(45)}$, a maior temperatura atingida é inferior a 0,8 $T_{f}$. Aumentando-se a pressão de soldagem $(\mathrm{P}) \mathrm{e}$ a velocidade (v), aumenta-se a temperatura máxima em uma dada distância como indicado na equação (1).

$$
T-T_{0}=\frac{q}{2 \pi \lambda \sqrt{r_{0}^{2}+z_{0}^{2}}} \exp \left[-\frac{v}{2 k}\left(w_{0}+\sqrt{r_{0}^{2}+z_{0}^{2}}\right)\right]
$$

onde:

$$
\begin{aligned}
& w_{0}=r \cos \theta-\xi \cos \alpha \\
& r_{0}=\xi^{2}+r^{2}-2 \xi r \cos (\alpha-\theta) \\
& d q=2 \pi \mu P \omega \xi^{2} d \xi d \alpha
\end{aligned}
$$

a definição das coordenadas está apresentada na figura 10.

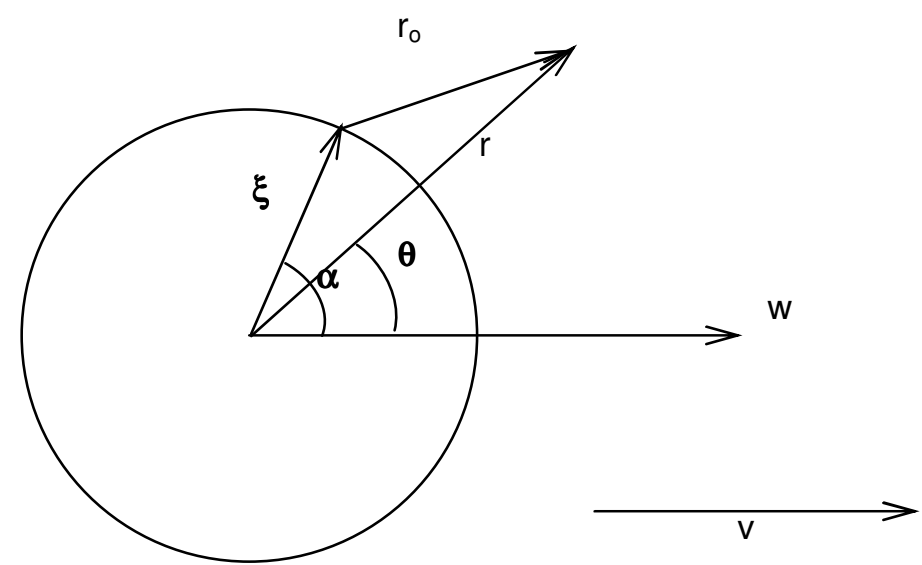

Figura 10 - Coordenadas do modelo de McClure ${ }^{(45)}$. 
Este modelo, apesar de prever a temperatura em posições ao redor da fonte de calor e a extensão da região afetada pelo aquecimento, não prevê a temperatura ao longo tempo. Isto é importante para avaliar cinética de reações de precipitação, recristalização e crescimento de grão.

Dentre os diversos modelos que existem na literatura, o $\operatorname{iSTIR}^{(46,47)}$ é um modelo térmico e analítico para 2D e 3D para a soldagem similar ou dissimilar de materiais metálicos por SALM. O modelo permite a simulação assimétrica da temperatura abaixo do ombro da ferramenta, produzida pela ação das velocidades de translação e de rotação e linear, tanto nas condições a quente e a durante a soldagem. A figura 11 mostra o processo iterativo do melhor ajuste entre um ciclo térmico experimental e calculado pelo modelo proposto. 
(a)

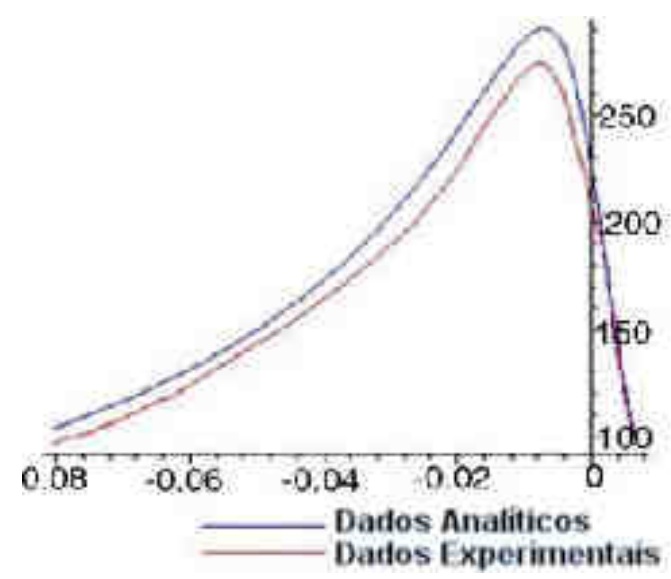

(b)

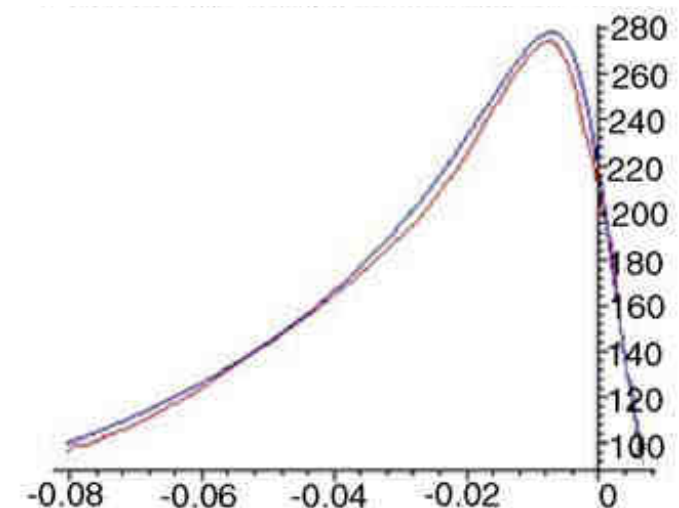

(c)

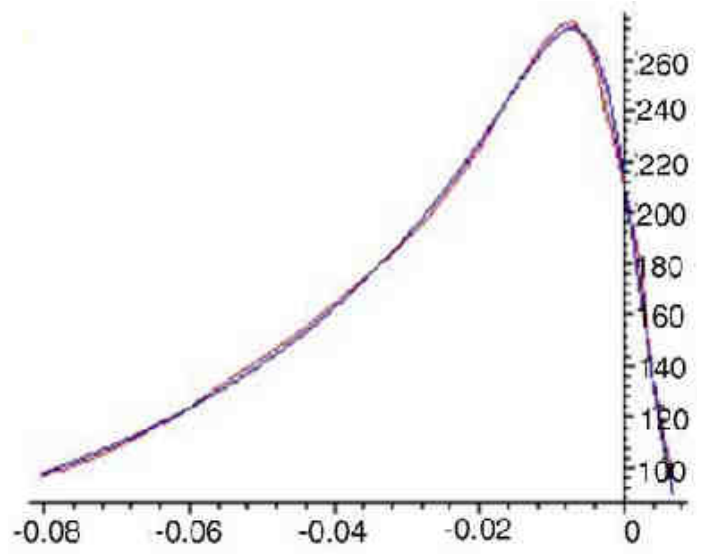

Figura 11 - Ciclos térmicos para a condição 2D em uma distância de 8,185 mm do centro do cordão para AA 6056-T4 com 3,9 mm de espessura, representando de (a) até (c) o melhor ajuste entre os valores medidos experimentalmente e os previstos pelo modelo analítico. Potência do processo $745 W^{(47)}$. 
Colegrove e Shercliff ${ }^{(48)}$, empregaram um modelo bi-dimensional plano para comparar a energia de soldagem e as forças de arraste da ferramenta com diferentes geometrias de pinos, velocidades de rotação da ferramenta e comportamento do material à deformação em temperatura elevada. Para compreender melhor qual o comportamento do material durante a soldagem por SALM foram feitas análises da pressão em torno da ferramenta; das tensões de deformação, das taxas de deformação e da temperatura do material durante a soldagem.

Resultados da interação do pino da ferramenta Triflat com velocidade translação de $1 \mathrm{~mm} / \mathrm{s}$ e velocidade de rotação de $120 \mathrm{rpm}$ para liga de alumínio AA 7449 com 20 $\mathrm{mm}$ de espessura estão mostrados na figura 12. Os valores da velocidade e os vetores de velocidade estão apresentados nas figuras 12(a) e 12(b), respectivamente. Observa-se nestas figuras que a deformação é maior na região próxima do pino, e como o material deformado é arrastado no lado de retrocesso da ferramenta.

O tamanho da região deformada na figura $12(b)$ foi determinado com base no desenho da superfície onde a taxa de deformação foi de $1 \mathrm{~s}^{-1}$. Esta escolha foi arbitrária, porém mostra que a escolha deste valor permite comparar este traçado com o campo dos vetores de velocidade ao lado da ferramenta e do material não deformado. A figura 12(c) mostra a variação da taxa de deformação, que é maior na superfície de contato entre o pino e o material e vai reduzindo na direção do metal base. Por último, a figura 12(d) apresenta a distribuição de temperatura, que é bastante uniforme ao redor do pino 


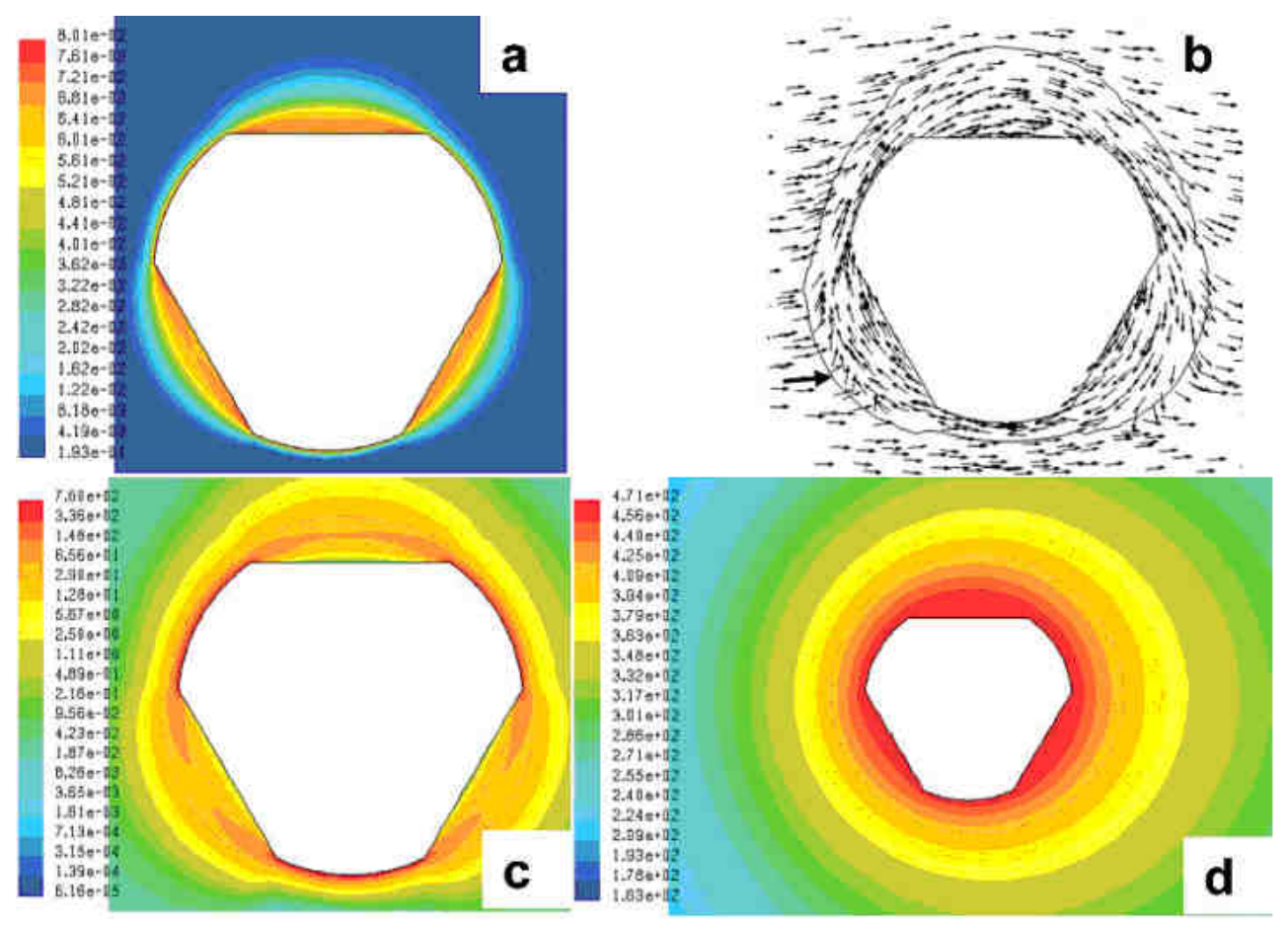

Figura 12 - Resultados da interação do pino da ferramenta Triflat com velocidade translação de $1 \mathrm{~mm} / \mathrm{s}$ e velocidade de rotação de $120 \mathrm{rpm}$ para liga de alumínio AA $7449 \mathrm{com} 20 \mathrm{~mm}$ de espessura. (a) contornos dos valores da velocidade $(\mathrm{m} / \mathrm{s})$; (b) vetores velocidade (mostrando uma superfície com taxa de deformação de $1 \mathrm{~s}^{-1}$ ); (c) taxa de deformação em s $\mathrm{s}^{-1}$ (observar que a escala é logarítmica); (d) contornos de temperatura $\left({ }^{\circ} \mathrm{C}\right){ }^{(48)}$.

A representação gráfica do campo da pressão em diferentes orientações de uma ferramenta Triflat está mostrada na figura 13. As pressões mais altas e mais baixas estão no lado do avanço. Os valores máximos são obtidos quando o lado plano da ferramenta está alinhado com o lado do retrocesso, conforme apresentado na figura 13(a). Isto porque a protrusão da ferramenta está movendo contra o fluxo de material, o que origina uma elevada diferença de pressão entre os dois locais da ferramenta. Quando essa parte da ferramenta está no lado do retrocesso, como indicado na figura 13(c), o fluxo de material é na mesma direção da rotação da ferramenta e, portanto, a diferença de pressão é muito menor. Desta maneira, para 
uma dada geometria de ferramenta, conforme sua posição instantânea pode ocorrer uma diferença de pressão dependendo da orientação futura da ferramenta.

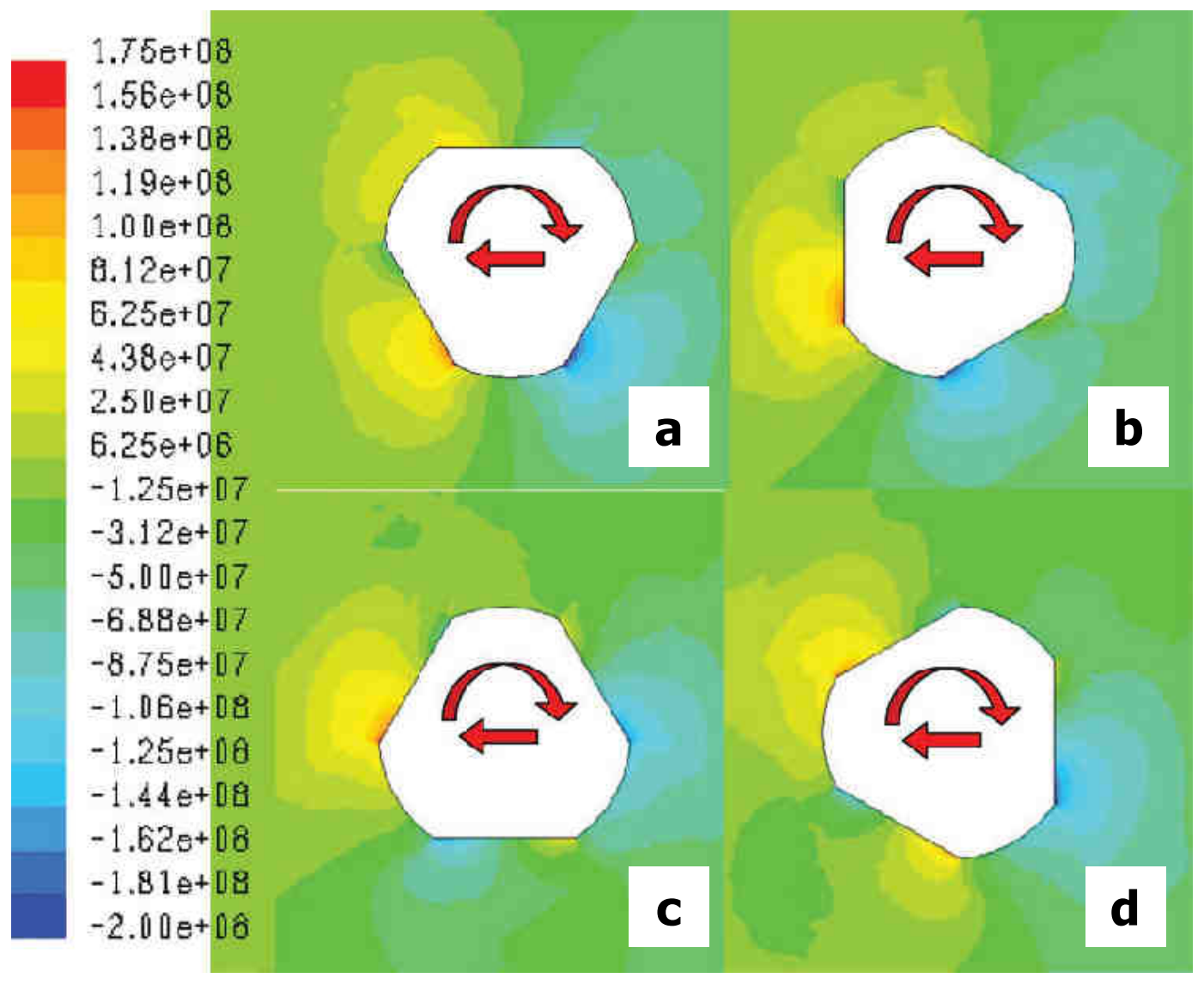

Figura 13 - Contornos de pressão $(\mathrm{Pa})$ do pino da ferramenta Triflat com velocidade translação de $1 \mathrm{~mm} / \mathrm{s}$ e velocidade de rotação de $120 \mathrm{rpm}$ para liga de alumínio AA $7449 \mathrm{com} 20 \mathrm{~mm}$ de espessura ${ }^{(48)}$.

Frigaard et al. ${ }^{(42,49)}$, propõe um modelo para a zona afetada pelo calor para o processo que se compõe de: modelo de fluxo de calor predizendo o ciclo térmico em uma dada distância, modelo da cinética da microestrutura da zona afetada pelo calor em função da temperatura e de equações baseadas na mecânica de discordâncias, que fornecem informação quantitativa sobre a dureza da zona afetada pelo calor. A figura 14 mostra um ciclo térmico medido experimentalmente e calculado segundo o 
modelo de Frigaard et al. ${ }^{(42,49)}$. Os parâmetros utilizados foram velocidade de translação de $5 \mathrm{~mm} / \mathrm{s}$, velocidade de rotação da ferramenta de $1500 \mathrm{rpm}$ e força de $7 \mathrm{kN}$.

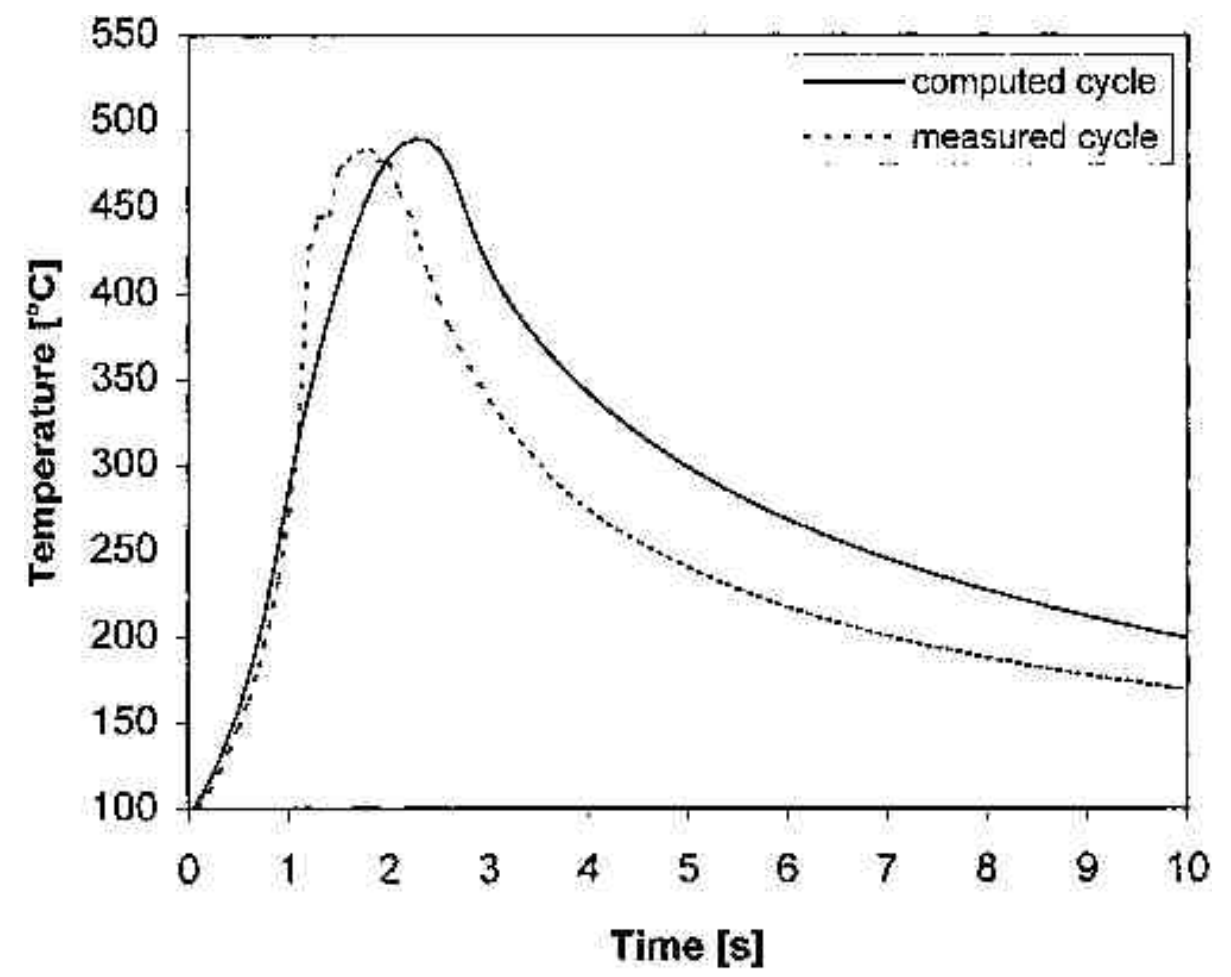

Figura 14 - Ciclo térmico para uma liga AA6082 obtido na região logo abaixo do ombro da ferramenta ${ }^{(42,49)}$.

O modelo é uma combinação de leis da termodinâmica com a teoria da difusão, descrevendo solubilização, re-precipitação e a cinética de envelhecimento natural das ligas, ocorrendo seqüencialmente no tempo, que foi proposto por Myhr e Grong ${ }^{(50,51)}$. Ele prevê a dureza e a resistência de soldas envelhecidas naturalmente, com uma correção empírica para velocidades de soldagem altas, onde a zona afetada pelo calor se sobrepõe com a região deformada plasticamente. Conseqüentemente, o modelo perde sua precisão no cálculo da dureza resultante ${ }^{(49)}$. Um exemplo de previsão de dureza esta mostrado na figura 15. 


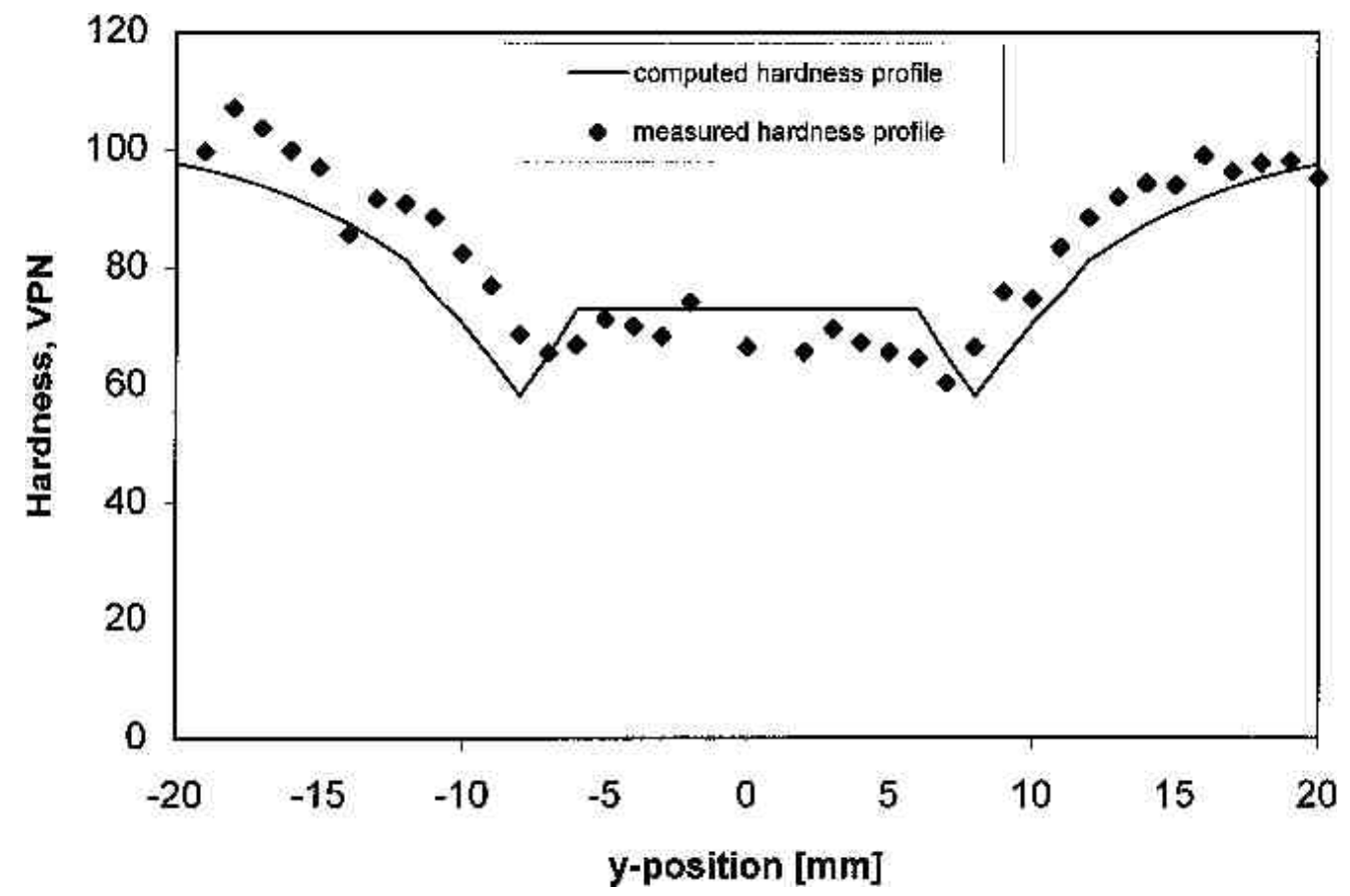

Figura 15 - Medidas de dureza experimentais e calculadas pelo modelo em liga de alumínio AA6082-T6. Parâmetros de soldagem: velocidade de $5 \mathrm{~mm} / \mathrm{s}$; velocidade de rotação do pino de $1500 \mathrm{rpm}$ e força de $7 \mathrm{kN}^{(42,49)}$.

O modelo de Frigaard ${ }^{(42,49)}$ trata como a principal causa para a perda de resistência e de dureza dos cordões de solda, os efeitos térmicos da soldagem, porém, o modelo não inclui no efeito térmico, o fenômeno de recristalização e de crescimento de grão.

No trabalho foi feito o tratamento térmico do cordão de solda para avaliar a alteração da microestrutura. Os resultados estão mostrados na figura 16. 
(a)
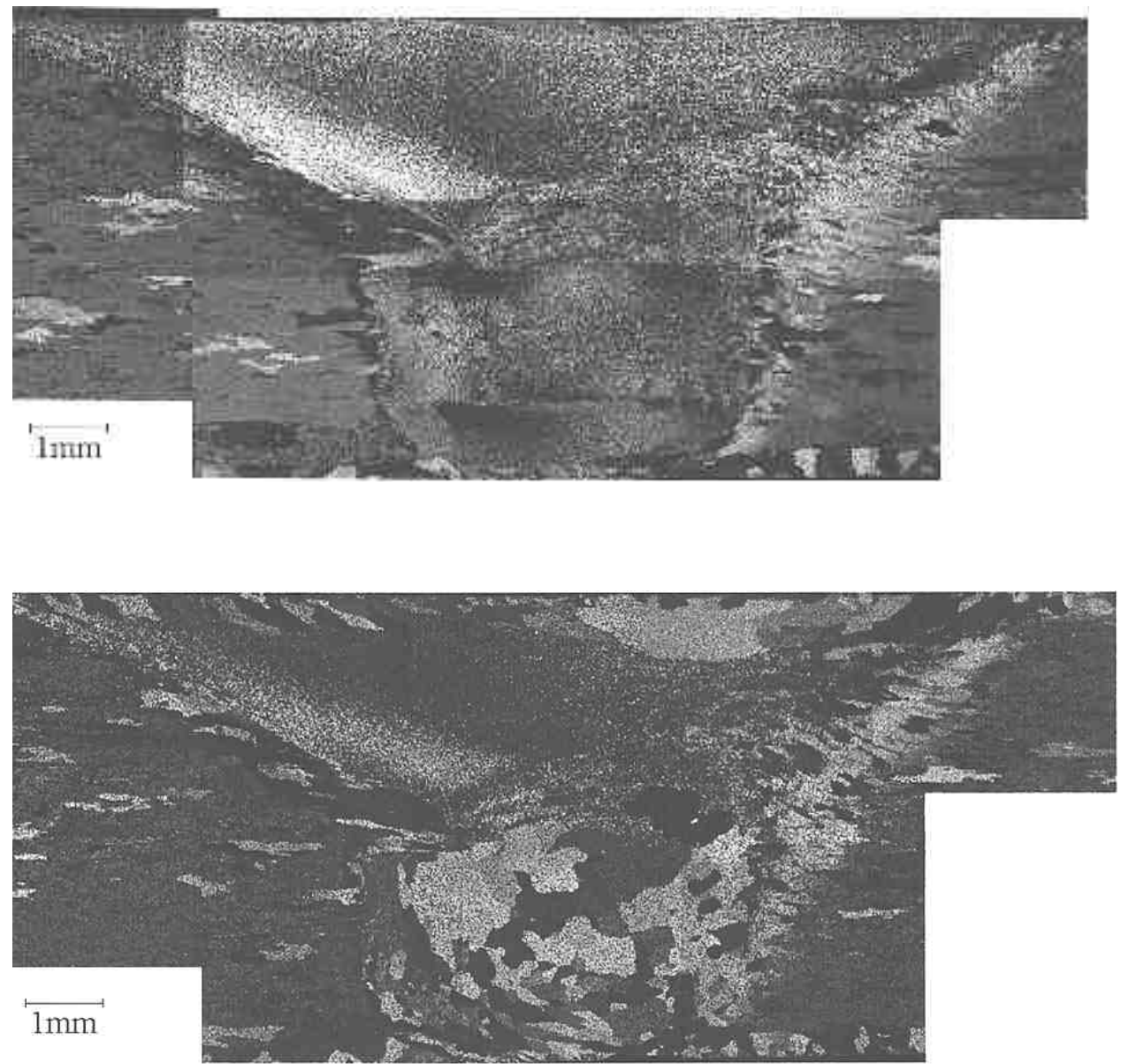

(b)

Figura 16 -Efeito do tratamento térmico na microestrutura da junta soldada por SALM da liga AA6082-T6. Em (a) na condição como-soldada e em (b) tratada a $510^{\circ} \mathrm{C}$ por $15 \min ^{(42,49)}$.

Para processos de soldagem com fenômenos de precipitação e crescimento de grão no material de base, os modelos também podem ser apresentados na forma de diagramas. Ashby, Easterling e lon $^{(40,43)}$, propõem um modelo baseado em transferência de calor, teoria da difusão e modelamento semi-empírico para prever a microestrutura da zona afetada pelo calor da soldagem por fusão. Os resultados do modelo são diagramas com eixos de tempo de resfriamento, de pico de temperatura atingido no processo e de distância do centro do cordão de solda. Os diagramas 
mostram a extensão do crescimento de grão, solubilização e crescimento de precipitados, transformações de fase e dureza resultante.

É possível, através destes diagramas, verificar a dependência da microestrutura com o calor fornecido no processo. A figura 17a ilustra um diagrama com eixos de tempo resfriamento, pico de temperatura e energia fornecida para o processo. Neste diagrama são estabelecidas as influências destas variáveis sobre tamanho de grão e solubilização de precipitados. A figura 17b apresenta um diagrama com eixos de energia oferecida, tempo de resfriamento e distância do centro do cordão. Neste diagrama são estabelecidas as relações destas variáveis sobre o tamanho de grão, solubilização de precipitados e dimensão da zona afetada pelo calor.

Grong $^{(52)}$ considera estes diagramas, como uma análise alternativa às técnicas de modelamento que necessitam de muitos cálculos em computador e são, devido à complexidade, limitadas a duas dimensões. Apesar de ser uma solução simplificada do problema, o valor deste modelo está no fornecimento de uma compreensão maior dos mecanismos físicos envolvidos, através da transparência dos diagramas. 
a)

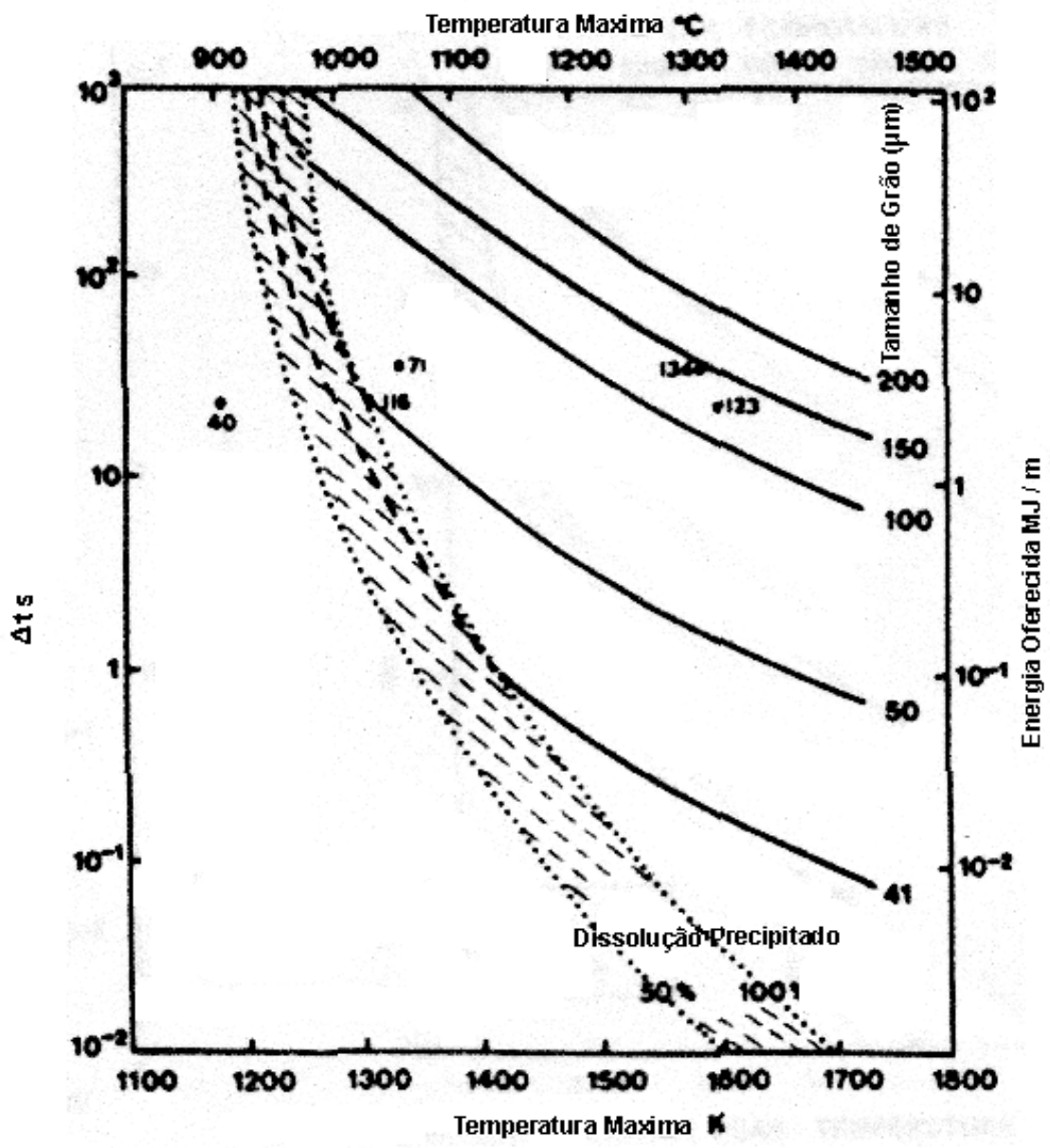

b)

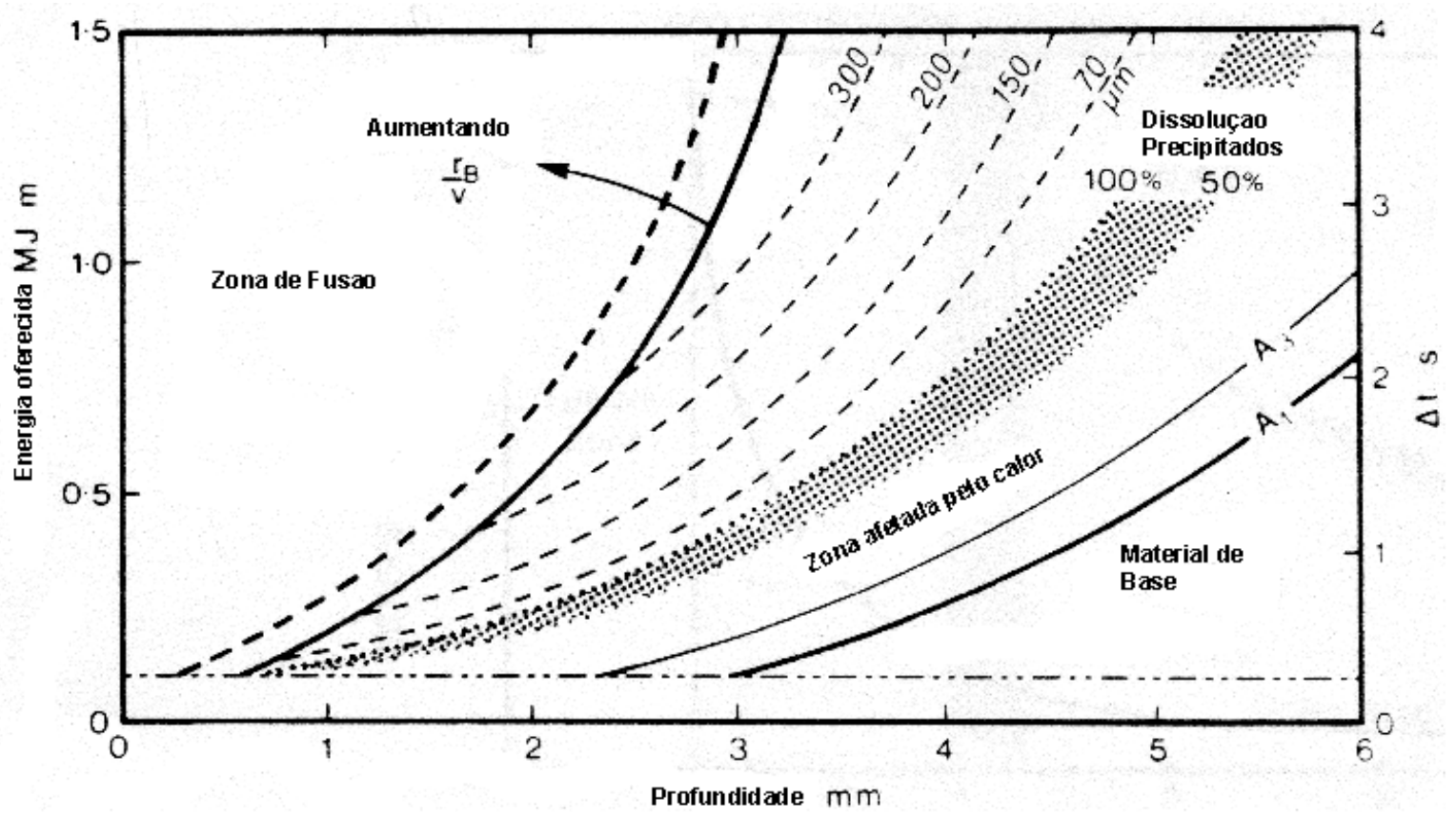

Figura 17 - a) Diagrama de Ashby. b) Diagrama de Ashby para a região do cordão de solda ${ }^{(40,}$ 43). 
O modelo de Ashby, Easterling e Ion ${ }^{(40,43)}$, utiliza as equações de Rosenthal para obter o perfil de temperaturas no tempo. O ciclo térmico da soldagem induz mudanças microestruturais no material da zona afetada pelo calor, que pode estar relacionada com a difusão durante o aquecimento gerado pelos ciclos térmicos. A equação (2) é necessária para todos os pontos dos diagramas:

$$
I=\int_{0}^{\infty} \exp -\left(\frac{Q}{R T(t)}\right) d t
$$

A equação (3) permite estimar fenômenos como o crescimento de grão e a precipitação, considerando-se as devidas constantes cinéticas e as energias de ativação. Para o crescimento de grão $g$ tem-se a seguinte equação:

$$
g^{2}-g_{0}^{2}=k_{1} \int_{0}^{\infty} \exp -\left(\frac{Q}{R T(t)}\right) d t
$$

Ashby, Easterling e Ion ${ }^{(40,43)}$, utilizam também para seus diagramas uma correção na equação (4), quando ocorre a interação entre o crescimento de grão e o crescimento de precipitados.

Dependendo da temperatura alcançada durante o ciclo de aquecimento, os precipitados na zona afetada pelo calor podem se dissolver. A temperatura de dissolução $T_{s}$ dos precipitados, utilizada nos diagramas, é dada por:

$$
T_{s}=\frac{B}{A-\log \left[\frac{C_{M}^{a} C_{N}^{b}}{f^{a+b}}\right]}
$$

A dureza da zona afetada pelo calor pode ser obtida através do cálculo da fração volumétrica de todos os constituintes que se formam. Com estes dados, e conhecendo a dureza de cada constituinte, uma regra para a mistura pode ser 
utilizada, conforme a equação (5), fornecendo um valor médio de dureza com boa $\operatorname{aproximação~}^{(43)}$.

$$
H=H_{1} V_{1}+H_{2} V_{2}+H_{n} V_{n}
$$

Análises indicam uma relação direta entre o ciclo térmico e o mínimo de resistência na zona afetada pelo calor $(42,53,54)$. Isto significa que todo potencial do SALM não pode ser utilizado na engenharia de projetos, devido à perda de resistência na zona afetada pelo calor, desconsiderando a possibilidade de endurecimento por precipitação.

Com relação ao fluxo de material, Arbegast ${ }^{(55)}$ propôs que o cordão era dividido em zonas de deformação. A zona de deformação de avanço (zona I) e de retrocesso (zona II) em volta do pino da ferramenta estão mostradas na figura 18. O material deformado que atravessa a zona II move-se para baixo e em torno do pino e converge para o material deformado na zona I. O material da zona II pode mover para baixo o suficiente para entrar zona IV, abaixo do final do pino e subir novamente para ser misturado com o material da zona I. O material da zona III surge pela deformação causada pelo ombro da ferramenta, e se move em direção à superfície externa do pino. Este fluxo de material é forçado para baixo e preenche a zona I também. Caso ocorra alguma falha nesta movimentação de material, poderá ocorrer uma série de descontinuidades no cordão de solda. 


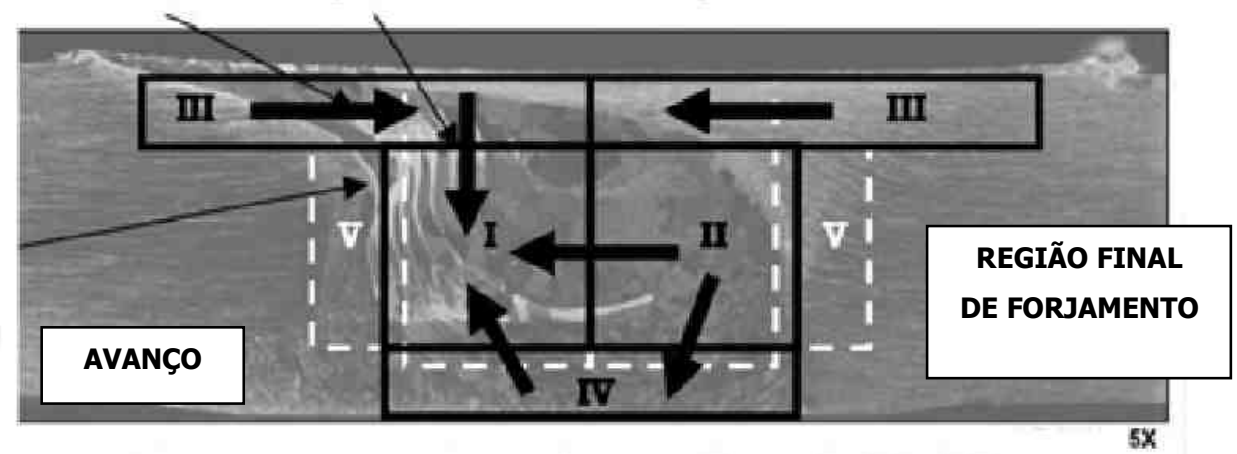

AVANÇO RETROCESSO

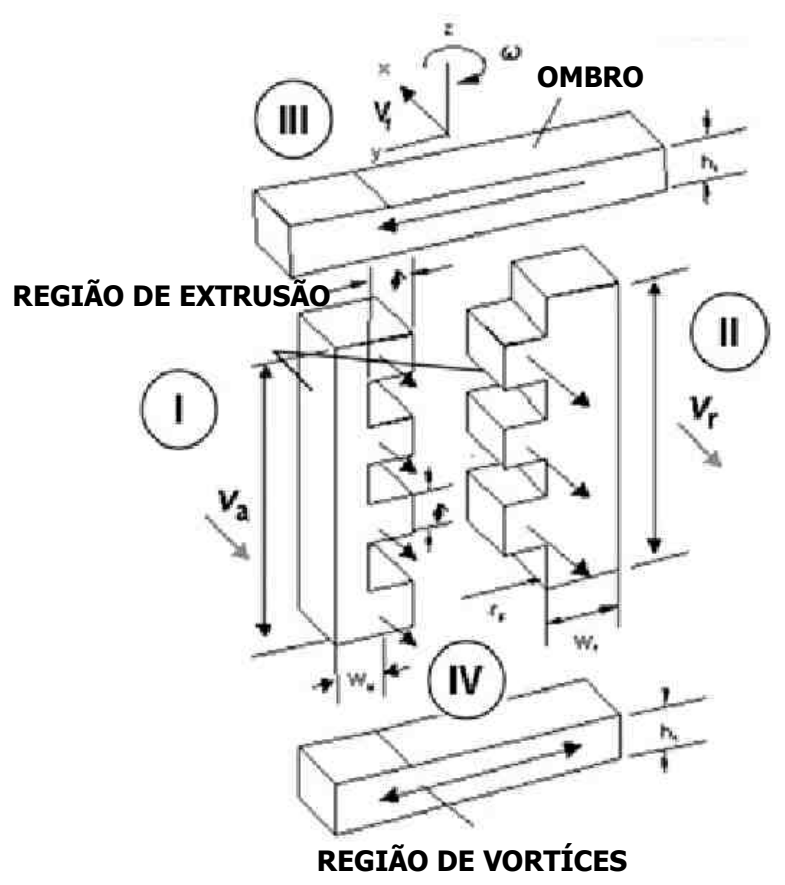

Figura 18 - Definição das regiões de deformação na soldagem SALM, na parte de trás do pino para ferramenta axi-simétrica ${ }^{(50)}$.

Conforme a relação entre a velocidade de translação e a velocidade de rotação pode ocorrer a interpenetração de uma região em outra ou mesmo o excesso ou falta de material em uma das regiões, que produzirão descontinuidades no cordão de solda. A figura 19 mostra a relação entre a velocidade de translação e de rotação e o fluxo de material deformado entre as diferentes regiões. 


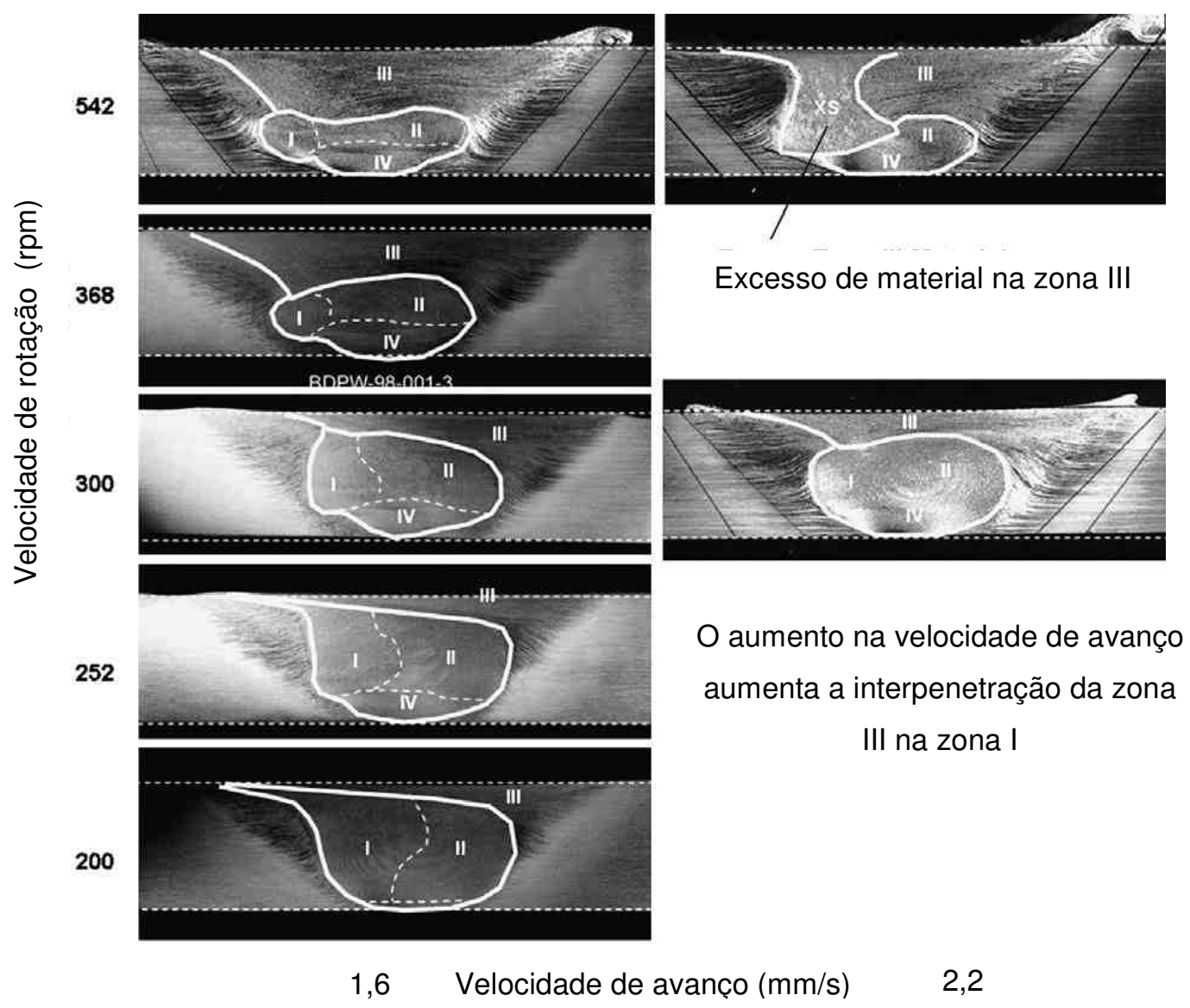

Figura 19 -Efeito da velocidade de avanço e de rotação nas regiões de deformação de material durante a soldagem por SALM de uma liga de alumínio ${ }^{(55)}$.

Os modelos apresentados são baseados em uma distribuição de temperatura, o mais próximo possível dos valores reais. A partir desta distribuição de temperaturas são acoplados ao modelo as taxas de deformação e o fluxo do material que está sendo soldado. A partir destes dados consegue-se, como no caso de ligas de alumínio endurecíveis por precipitação, estimar as propriedades mecânicas do cordão de solda por SALM. 


\subsection{Recuperação e Recristalização}

Durante a soldagem por atrito linear com mistura podem ocorrer a recuperação e/ou a recristalização no cordão de solda e na zona afetada pelo calor, caso o metal de base esteja deformado plasticamente.

Na recuperação de um material, após a deformação plástica, este adquire as suas propriedades mecânicas próximas do material sem deformação. A recuperação é decorrente da aniquilação de defeitos cristalinos (discordâncias) em temperaturas de 0,2 a 0,3 $T_{f}$ e da formação de subgrãos por poligonização em temperaturas acima de 0,4 $T_{f}$. A cinética da recuperação pode ser descrita pela redução da densidade de discordâncias $\rho$ ao longo do tempo $t$, como indicado na equação $(6)^{(56)}$ :

$$
\frac{1}{\rho}-\frac{1}{\rho_{0}}=k t
$$

À medida que a temperatura de deformação é aumentada, a recuperação é mais intensa, diminuindo o potencial termodinâmico para a recristalização. A recuperação pode ocorrer de forma estática, através do aquecimento do material, ou dinamicamente sob tensão e aquecimento durante a deformação.

O alumínio apresenta uma elevada energia de falha de empilhamento (EDE) $(0,2$ $\mathrm{J} / \mathrm{m}^{2}$ ou $200 \mathrm{erg} / \mathrm{cm}^{2}$ ), tendo assim as suas discordâncias parciais próximas umas das outras e, conseqüentemente, facilitando a sua mobilidade. Isto favorece o fenômeno de recristalização.

A recristalização inicia-se com a nucleação de uma região livre de defeitos através de mecanismos de rearranjo de discordâncias. Esta região é delimitada por um 
contorno de alto ângulo e com alta mobilidade sobre a matriz encruada ou, previamente recuperada.

O potencial termodinâmico para que a reação de recristalização ocorra é a energia armazenada na deformação, oriunda do processo de soldagem SALM. As heterogeneidades de deformação são locais preferenciais para a nucleação da recristalização ${ }^{(56)}$. As nucleações da recristalização em ligas de alumínio, que apresentam alta EDE, podem ocorrer através da migração de contornos de grão induzida por deformação e pelo coalescimento de subgrãos.

A migração de contornos ocorre entre grãos com diferentes taxas de deformação, onde o contorno cresce sobre os grãos deformados. Esta nucleação foi observada em materiais com menos de $40 \%$ de deformação ${ }^{(56)}$.

O coalescimento de subgrãos consiste do coalescimento de dois subgrãos vizinhos resultando em reticulados cristalinos coincidentes através da rotação de um deles, eliminando o contorno de baixo ângulo. Este mecanismo de rearranjo foi observado no alumínio entre $0,4 T_{f}$ e $0,5 T_{f}$.

Após a nucleação a recristalização pode ocorrer pela migração dos contornos de alto ângulo sobre a matriz encruada, porém em alguns materiais esta migração é suprimida ${ }^{(56)}$.

A migração pode ser diminuída em sua velocidade através de forças retardadoras como $(56,57,58,59)$ : dispersão de precipitados e átomos de soluto. No caso de dispersão de precipitados esta força retardadora é influenciada por dois parâmetros: o diâmetro médio das partículas e espaçamento entre as partículas. Quanto maior for o diâmetro médio das partículas e quanto menor for o espaçamento entre elas, maior será esta força retardadora. 
Átomos de soluto como $\mathrm{Si}, \mathrm{Mn}, \mathrm{Mg}, \mathrm{Cr}$ e $\mathrm{Zr}$ diminuem a EDE e conseqüentemente inibem a recristalização. Nas ligas da série AA 6XXX, os elementos Si e Mg são constituintes do material e formam o precipitado $\mathrm{Mg}_{2} \mathrm{Si}$ e os elementos $\mathrm{Mn}, \mathrm{Cr}$ e $\mathrm{Zr}$ também inibem a recristalização, pois precipitam em contorno de grão na forma de precipitados e aglomerados ${ }^{(60)}$.

$\mathrm{Na}$ extrusão de ligas de alumínio da série AA 6XXX não ocorre a recristalização durante a deformação a quente, denominada também de recristalização dinâmica, ocorrendo apenas recuperação dinâmica ${ }^{(60)}$.

\subsection{Crescimento de Grãos e Recristalização Secundária}

O crescimento de grão ocorre pela movimentação dos contornos de alto ângulo sobre os grãos termodinamicamente menos estáveis. O potencial termodinâmico para esta reação é a diminuição dos contornos de alto ângulo.

Quando todos os grãos crescem e apresentam no crescimento um tamanho próximo ao médio, denomina-se este de crescimento normal de grão. Quando o crescimento é preferencial em alguns grãos este se denomina de crescimento anormal, ou recristalização secundária. Assim, irá ocorrer uma diferença no perfil da distribuição de tamanhos de grão ao longo de sua ocorrência. A figura 20 ilustra as situações de crescimento de grão normal e anormal. 


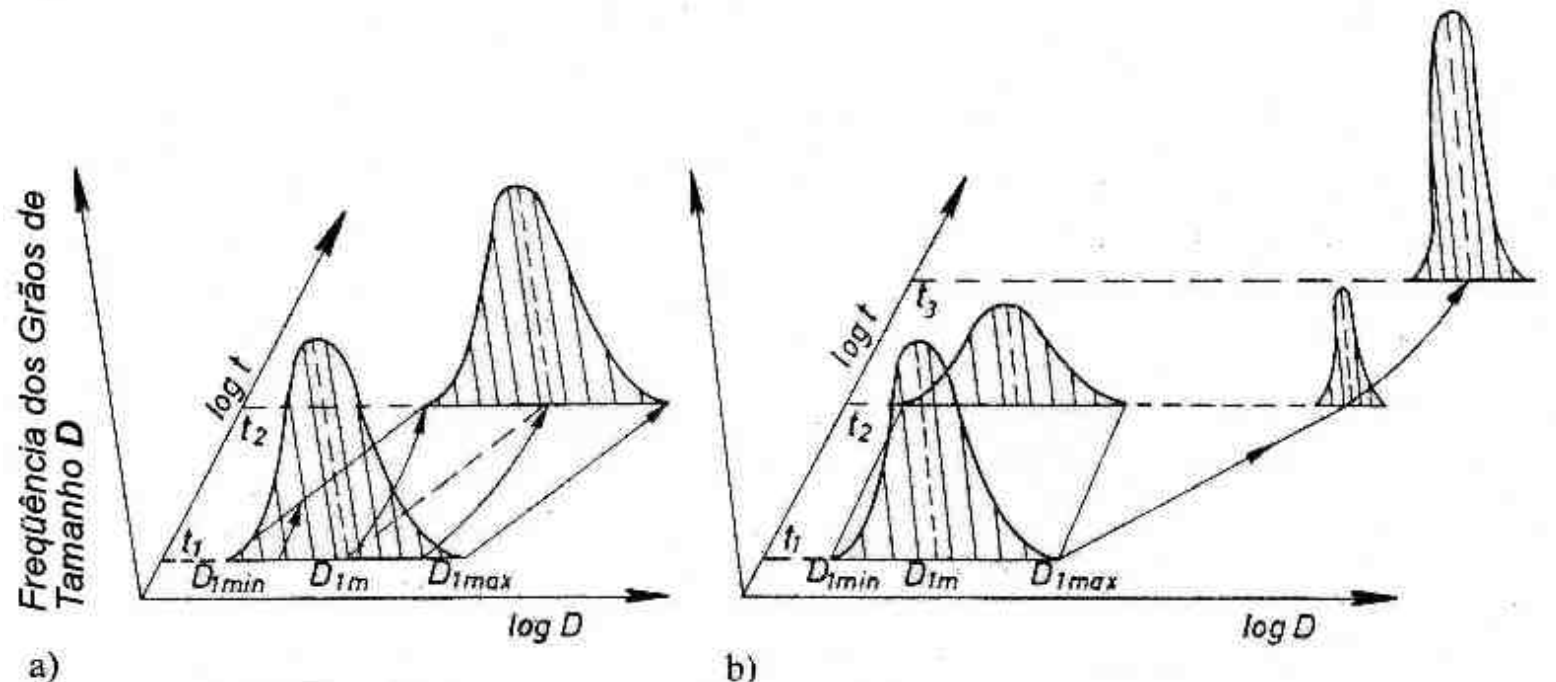

Figura 20 - Representação esquemática do crescimento (a) normal (b) anormal de grãos de tamanho médio $D$ ao longo do tempo $t^{(58)}$.

O crescimento anormal de grãos tem sido acompanhado experimentalmente de diferentes formas, como por exemplo, medida de fração volumétrica de grãos grossos, tamanho médio dos grãos com crescimento anormal e distribuição bidimensional de tamanhos de grão. Com os resultados obtidos de fração volumétrica de grãos com crescimento anormal é possível a descrição do fenômeno pela equação (7) de Johnson-Mehl-Avrami-Kolmogorov ${ }^{(61)}$ :

$$
V_{v}=1-e^{-b t^{c}}
$$

O tamanho médio dos grãos que cresceram anormalmente pode ser acompanhado e descrito pela equação (8) ${ }^{(62)}$ :

$$
D=V\left(t-t_{0}\right)
$$

onde $t_{0}$ : tempo de incubação.

A recristalização secundária é favorecida por impurezas em solução sólida, presença de partículas, presença de textura pronunciada e espessura do material ${ }^{(56)}$. 
Para metais deformados severamente, como no processo ECAP, o crescimento anormal do grão também está relacionado com a presença de fortes texturas, onde há uma instabilidade elevada dos contornos de subgrão, principalmente os contornos com orientações inferiores a $5^{\circ}$. A instabilidade também pode ocorrer se um grão particular tem uma diferença de orientação na região onde ele está presente acima do valor médio das orientações da região ${ }^{(63)}$.

Yu et al. ${ }^{(64)}$, identificaram que para a liga de alumínio AA 1050 deformada severamente pelo processo de extrusão Equal Channel Angular Extrusion (ECAE), recozida na faixa de temperatura de 275 a $300^{\circ} \mathrm{C}$, ocorre o crescimento anormal de grão. Isto porque nesta faixa de temperatura a energia de ativação para a recristalização tem uma mudança descontínua no seu valor. Abaixo de $275^{\circ} \mathrm{C}$, a energia de ativação para a recristalização encontrada foi mais baixa, da ordem de 49 $\mathrm{kJ} / \mathrm{mol}$, devido à alta mobilidade atômica dos contornos de grão fora do equilíbrio. Para temperaturas acima de $300 \stackrel{\circ}{\circ}$ a energia de ativação é de $84 \mathrm{~kJ} / \mathrm{mol}$, próximo a energia de ativação em contorno do grão do alumínio. Um estudo similar foi realizado por Lewandowska et al. ${ }^{(65)}$, que além da temperatura onde esta transformação ocorre ele conclui também que tempos elevados podem levar a recristalização secundária de matérias deformados severamente, devido a alta mobilidade atômica dos contornos grão de não equilíbrio ${ }^{(66)}$.

No SALM a recristalização secundária é comum para as ligas de alumínio tratáveis termicamente e está relacionada com a deformação heterogênea do processo e a presença de partículas. A recristalização secundária pode ser minimizada na soldagem SALM através da escolha ideal de parâmetros de soldagem, geometria da ferramenta, aporte de calor e fluxo de material ${ }^{(67)}$. 


\subsection{Precipitação durante a recristalização}

Uma liga supersaturada e deformada pode recristalizar-se em temperaturas similares da precipitação de partículas de segunda fase. A temperatura de tratamento irá determinar a seqüência e ocorrência dos fenômenos: para temperaturas acima da temperatura de solubilização $(T s)$ da liga irá ocorrer somente a recristalização da liga, sem precipitação; para temperaturas abaixo da solubilização e acima da temperatura de tratamento com tempo comum para o início da recristalização e precipitação $\left(T_{2}\right)$ irá ocorrer a recristalização seguida da precipitação; para temperaturas abaixo de $\left(T_{2}\right)$ irá ocorrer somente a precipitação das partículas de segunda fase, influenciando a distribuição das discordâncias e o rearranjo dos subgrãos na recuperação ${ }^{(56)}$.

Outro modo de precipitação durante a recristalização é a precipitação descontínua que ocorre junto à frente de reação da recristalização ${ }^{(56)}$. Para temperaturas próximas a de solubilização neste modo de precipitação a recristalização não sofre influência. Para temperaturas inferiores a de solubilização ocorre a precipitação descontínua junto a recristalização, e a sua cinética é acelerada devido ao aumento do potencial termodinâmico para a migração de contornos. Em temperaturas mais baixas a precipitação contínua e descontínua é intensa o suficiente para impedir a migração dos contornos de alto ângulo, que é denominado também de recristalização contínua ${ }^{(56)}$.

\subsection{Características da Solda por SALM}

A seção do cordão resultante no SALM pode ser caracterizada pelo formato denominado de "onion rings", normalmente, em ligas de Al de alta resistência e 
baixa capacidade de extrusão, e pelo formato de taça. $O$ formato da seção também está relacionado com os parâmetros de processo ${ }^{(68)}$. A zona termo-mecanicamente afetada pelo calor está ilustrada na figura 21 .

Os grãos do material após a soldagem, conforme mostra a figura 21, são distribuídos em: região $D$ da solda, que é constituída de uma estrutura fina de 2 a $20 \mu m$, com baixa densidade de discordâncias, recristalizada dinamicamente, devido ao calor gerado no atrito e à alta deformação plástica do fluxo de material; regiões $C$ e $B$, que são caracterizadas pela recuperação dos grãos, e também como uma região afetada termicamente. A classificação dos grãos nem sempre é consistente com o perfil de dureza, pois esta característica mecânica depende das propriedades dos precipitados $^{(54,68)}$.

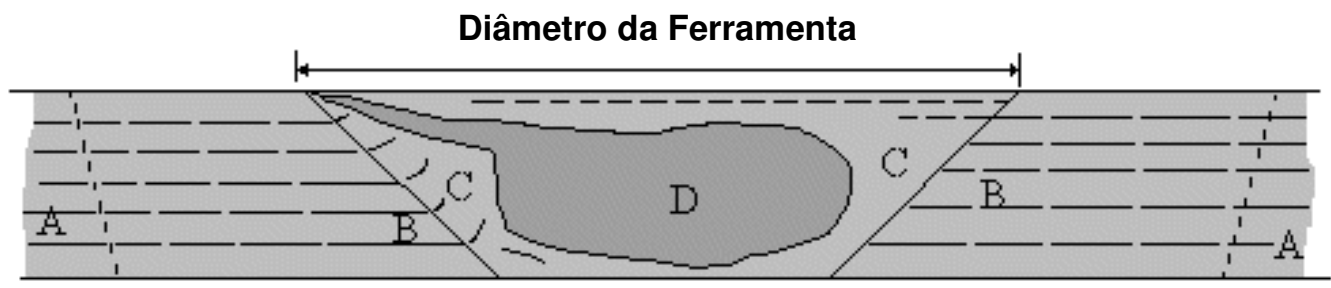

Figura 21 - Zona termo-mecanicamente afetada pelo calor: A- Material não afetado; BTermicamente afetado; C- Termo-mecanicamente afetado - plasticamente deformado, com áreas recristalizadas; D- Dinamicamente recristalizado ${ }^{(19)}$.

O SALM, em ligas endurecíveis por precipitação, produz uma região de dureza inferior a do metal de base, caracterizada pela solubilização e/ou coalescimento dos precipitados, conforme o ciclo térmico da região do cordão. A região com precipitados dissolvidos tem um mínimo de dureza na condição soldada. O perfil de dureza da solda destas ligas apresenta uma queda no centro do cordão ${ }^{(54,68,69)}$. Conforme a curva de resfriamento e a reação de formação de precipitados obtêm-se regiões solubilizadas e super-envelhecidas. 
A tabela 3 apresenta diferentes temperaturas de precipitação de uma liga $\mathrm{Al}-\mathrm{Mg}-\mathrm{Si}$, com $1 \%$ de $\mathrm{Mg}$, variando a quantidade de $\mathrm{Si}$, como também as respectivas energias de ativação obtidas pelo método de Kissinger.

Tabela 3 - Energias de Ativação (kJ/mol) para liga Al-Mg-Si, adaptado de Afify et al. ${ }^{(70)}$ e Temperaturas $\left({ }^{\circ} \mathrm{C}\right)$ de precipitação e dissolução de precipitados da liga AA 6005 , adaptado das referências ${ }^{(50,71,72)}$.

GP $\quad \beta^{\prime \prime} \quad \beta^{\prime} \quad \beta$

Baixa $\mathbf{C}_{\mathbf{S i}}$

Energia de Ativação (kJ/mol) $\quad 31,2 \pm 6,8 \quad 127,4 \pm 5,2 \quad 182,3 \pm 3,4 \quad 277,9 \pm 5,9$ $\mathrm{C}_{\mathrm{Mg}} / \mathrm{C}_{\mathrm{Si}}<\mathbf{1 , 7}$

Energia de Ativação (kJ/mol) 63,4 $46,9 \quad 104, \pm 5,5 \quad 110,0 \pm 5,0 \quad 135,4 \pm 5,8$

$\begin{array}{lllll}\text { Precipitação }\left({ }^{\circ} \mathrm{C}\right) & 160 & 260 & 290 \text { a } 310 & 460 \text { a } 470\end{array}$

Solubilização $\left({ }^{\circ} \mathrm{C}\right) \quad 200$ a $220 \quad 265 \quad 380$ a $420 \quad 500$ a 510

Segundo Pino et al. ${ }^{(73)}$, a energia de ativação da precipitação da fase $\beta$ para a liga AA 6063 com 0,36\% de Si é de 85,4 kJ/mol. Myhr e Grong ${ }^{(50)}$, estimaram para a liga AA 6082 uma energia de $190 \mathrm{~kJ} / \mathrm{mol}$ para a solubilização dos precipitados $\beta$.

Estas energias e temperaturas variam também com a deformação do material. Para deformações severas as temperaturas de precipitação diminuem e as energias de ativação também, devido ao aumento da difusão do Si no material ${ }^{(74,75)}$. Nas ligas endurecíveis por precipitação AA 6063 a seqüência de precipitação é ${ }^{(54)}$ :

solução sólida super-saturada $\rightarrow$ precipitados na forma de agulha B" $\rightarrow$ precipitados $\mathrm{B}^{\prime} \rightarrow \mathrm{B}-\mathrm{Mg}_{2} \mathrm{Si}$

A precipitação da fase $\beta$ " pode ser suprimida para altas deformações ${ }^{(75)}$. 
A redução na quantidade dos precipitados finos B" diminui a dureza do material. $O$ super-envelhecimento das ligas 6063 forma e coalesce os precipitados B' e reduz a densidade de precipitados B", ocasionando a queda de dureza na liga. A figura 22 mostra o resultado do efeito térmico no crescimento e solubilização dos precipitados através de um perfil de dureza transversal ao cordão da solda por SALM, no topo, no centro e na raiz do cordão.

Na figura 22, na região SOF, não são encontrados precipitados, na região MIN há a presença de somente precipitados super-envelhecidos B', na região LOW há a presença de precipitados B" e B', e no metal de base BM há a presença de uma grande quantidade de precipitados B" e poucos B'. A quantidade de precipitados B" diminui do metal de base para o centro do cordão.

A temperatura de solubilização dos precipitados B" é inferior à dos precipitados B', que por sua vez é inferior à do $\mathrm{B}-\mathrm{Mg}_{2} \mathrm{Si}$ que é próxima de $517,8^{\circ} \mathrm{C}$.

Conforme o ciclo térmico resultante da soldagem obtém-se em temperaturas máximas inferiores a de solubilização dos precipitados B", o crescimento de B" para B' na região LOW, diminuindo a densidade de B" e, conseqüentemente, reduzindo a dureza. Em temperaturas máximas superiores à de solubilização de B”, porém, abaixo da temperatura de solubilização de B', os precipitados B" são solubilizados na região MIN. Nesta região MIN permanecerão somente precipitados superenvelhecidos, resultando numa dureza mínima. Na região SOF a temperatura máxima atingida é superior à de solubilização de B' e B", tornando a região livre de precipitados e com dureza baixa. 


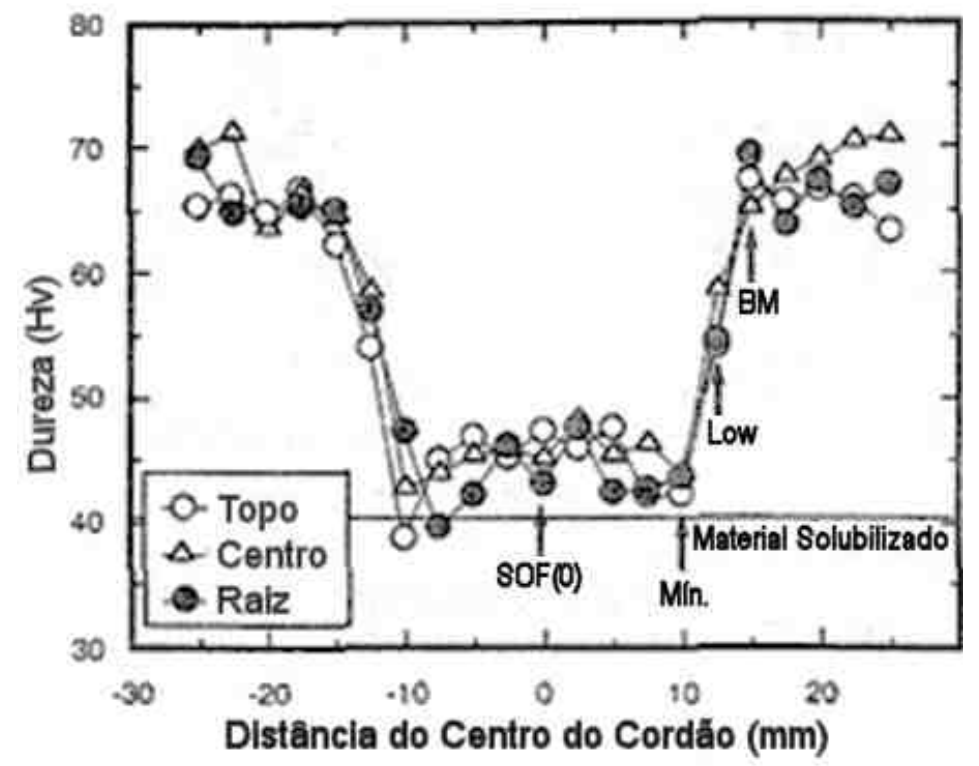

Figura 22 - Perfil de dureza para cordão de Al 6063 soldado por SALM ${ }^{(68)}$.

A figura 23 mostra uma análise por TEM da evolução dos precipitados nas regiões BM, LOW, MIN e SOF.

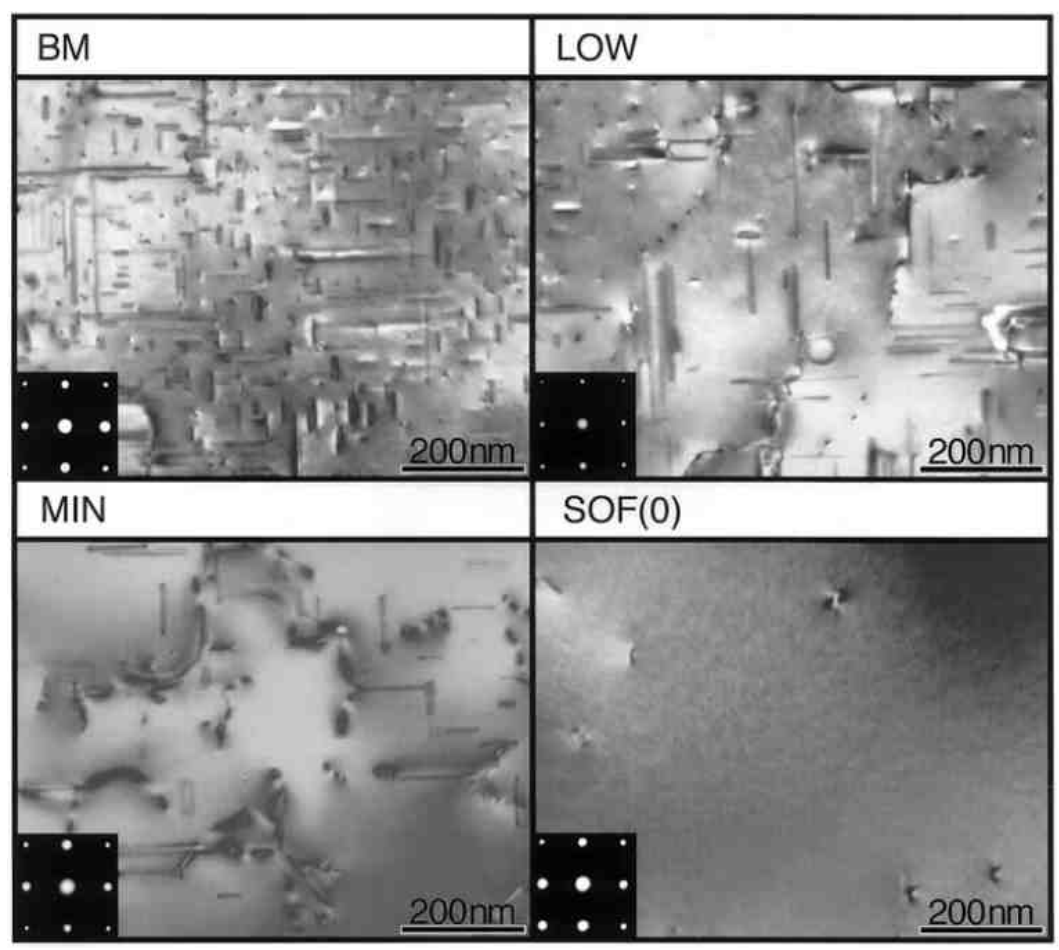

Figura 23 - TEM da solda SALM com precipitados em diferentes regiões ${ }^{(54,68)}$. 
Resultados similares foram obtidos por Simar ${ }^{(71)}$ que caracterizou a precipitação nas regiões amolecidas e endurecidas do cordão SALM através de ensaios de calorimetria. A figura 24 apresenta as diferentes temperaturas de precipitação e solubilização das fases em diferentes locais do cordão identificadas.

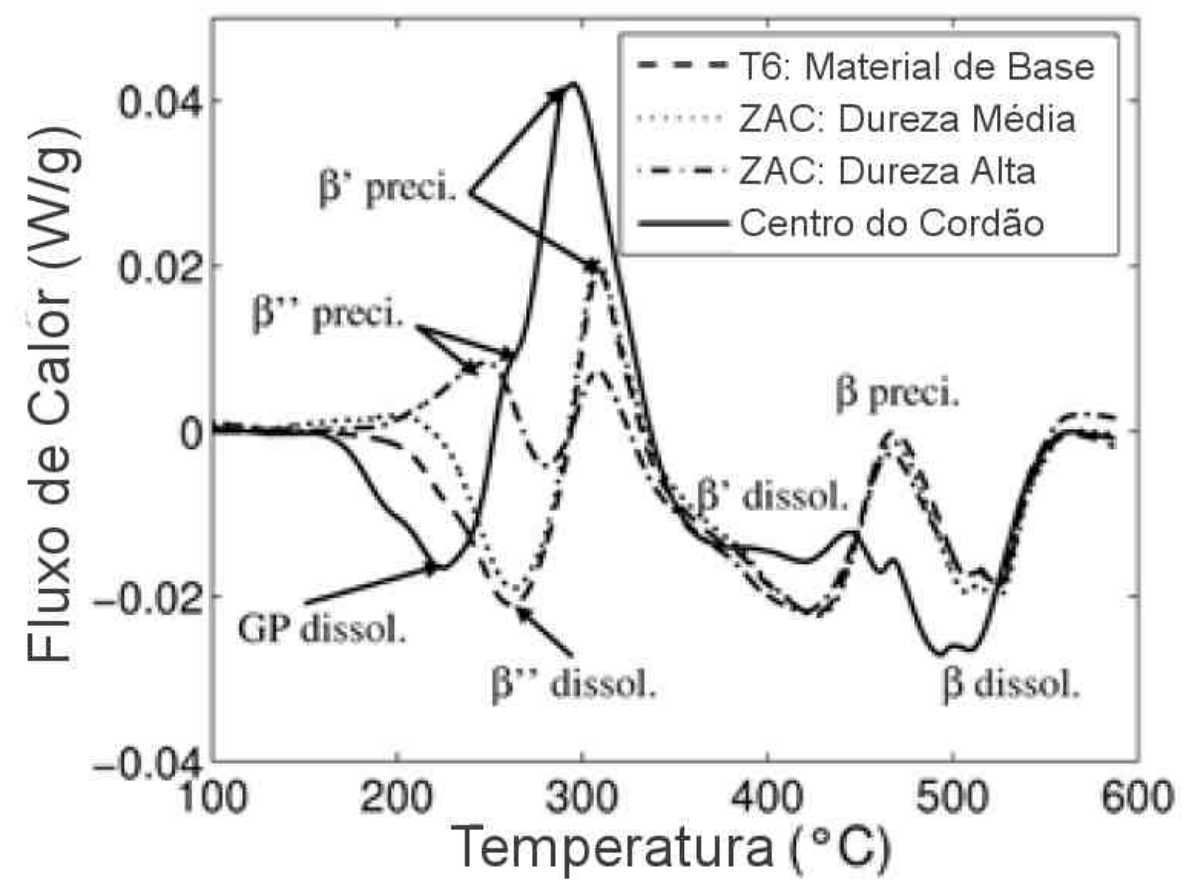

Figura 24 - Curva do fluxo de energia obtida por calorimetria diferencial em amostras de cordão de solda AA 6005 em diferentes regiões do cordão e material de base ${ }^{(71)}$.

A realização de uma solubilização após soldagem com envelhecimento resulta numa alta densidade de precipitados dando uma dureza homogênea em toda a solda ${ }^{(76)}$. Porém, a solubilização e envelhecimento não são sempre desejáveis industrialmente, pois resultam no aumento de operações e de custos.

A condição de resfriamento após a soldagem influencia na dureza do cordão de ligas envelhecíveis artificialmente. Para a liga AA 6063 foram obtidos resultados de dureza superiores com resfriamento com água ${ }^{(77)}$.

As reações com os precipitados ocorrem na zona afetada pelo calor, que tem largura próxima ao diâmetro da ferramenta e diminui distanciando-se da superfície. É 
importante conhecer os fatores que influem na taxa de crescimento dos precipitados para evitar o super envelhecimento ${ }^{(78)}$.

No SALM também se encontram outros precipitados que não tem influência sobre a dureza do cordão. Durante a solidificação das ligas industriais da série AA 6XXX existe a presença de outros elementos de liga além do Mg e Si. Estas fases podem ser classificadas em intermetálicos ricos em Fe do tipo Al-Fe, Al-Fe-Si e Al-Fe-Mn-Si e dispersóides que contem menos Fe e são ricos em Mg e Cr. Estes precipitados de $\alpha$ (AlFeMnSi) não dissolvem no cordão de SALM e são fragmentados durante 0 processo SALM $^{(71)}$.

Depois do endurecimento por precipitação, para ligas tratáveis, a forma mais significativa para alterar as propriedades do cordão é através do aumento de densidade de discordâncias. Este aumento está limitado a $40 \mathrm{Mpa}{ }^{(79)}$. A recristalização ocorrida durante a soldagem tem influência significativa na propriedade mecânica final do cordão.

Segundo Kallee e Masaki ${ }^{(19,80)}$, a recristalização dinâmica ocorre no cordão SALM devido às tensões existentes durante a soldagem. Desta forma, o modo de deformação tem importância na microestrutura final do cordão. O modo de deformação na região da ferramenta é similar à extrusão ${ }^{(81)}$. Segundo Arbegast ${ }^{\left({ }^{(2)}\right)}$, os modos de deformação são extrusão e forjamento e o processo de SALM apresenta cinco regiões distintas: (a) pré aquecimento, (b) deformação inicial, (c) extrusão, (d) forjamento, e (e) resfriamento. 
A figura 25 ilustra estas regiões no cordão.

(a)

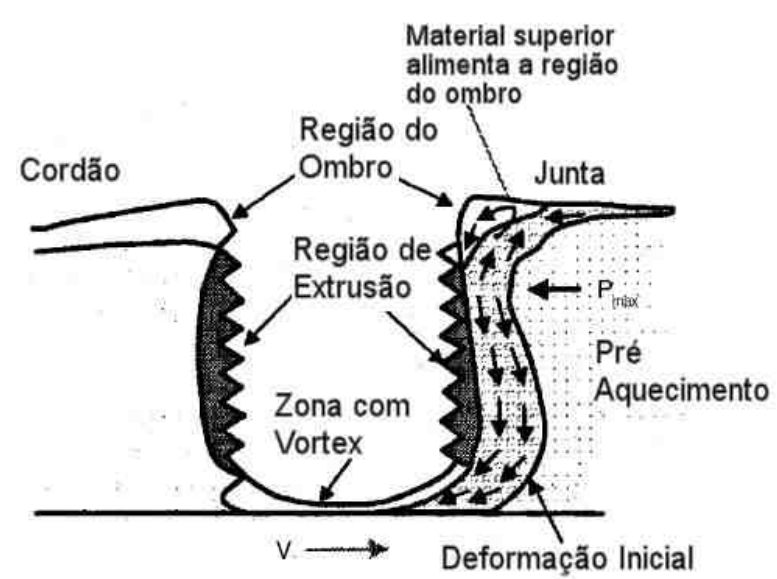

(b)

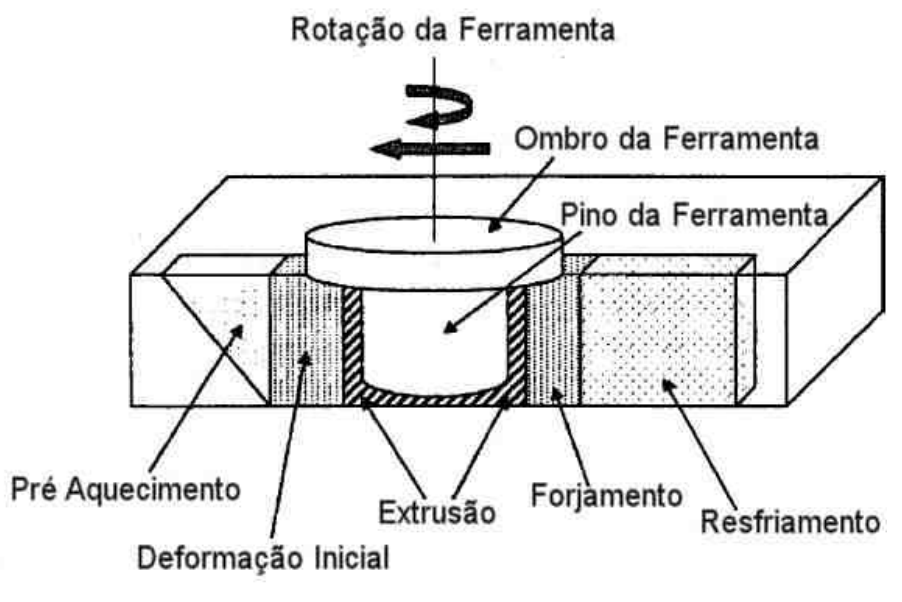

Figura 25 - (a) Padrões de fluxo de material. Seção longitudinal da ferramenta, junta e cordão. (b) regiões desenvolvidas durante o processo SALM ${ }^{(82)}$.

Mcnelley et al. ${ }^{(57)}$ comparam os fenômenos de recristalização no processo de SALM de alumínio com os fenômenos de recristalização de obtenção de partículas nanocristalinas através de deformações plásticas severas. Segundo eles os mecanismos atuantes na recristalização são recuperação dinâmica e recristalização dinâmica ${ }^{(57)}$. Apesar do fenômeno da recristalização dinâmica não ser esperado, a estrutura resultante de grãos finos, alta fração de grãos com contorno de grão de alto ângulo sugere a ocorrência da recristalização dinâmica ${ }^{(83)}$.

A ocorrência de recuperação dinâmica, ou recristalização dinâmica durante o processo de soldagem é muito discutido na literatura. Encontram-se autores que defendem a recristalização dinâmica e a utilizam em seus modelos ${ }^{(84,85,86,87)}$. Dumont et al ${ }^{(88)}$, afirmam que a recristalização dinâmica não ocorre devido ao efeito das partículas e precipitados das ligas de alumínio. Frigaard et al ${ }^{(49)}$, desenvolveram um modelo de processo que prevê somente a recuperação dinâmica do material. 
McNelley et al ${ }^{(57)}$, identifica diferentes tipos de recuperação dinâmica durante o processo de soldagem.

Materiais que sofrem recuperação dinâmica têm o tamanho de subgrão relacionado com a temperatura e a taxa de deformação através do parâmetro de Zener-Hollomon

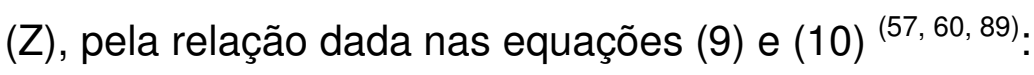

$$
\begin{gathered}
Z=\dot{\varepsilon} \exp \left(\frac{Q}{R T}\right) \\
d^{-m}=x+y \log \frac{Z}{A^{\prime}}
\end{gathered}
$$

Conforme as equações (9) e (10), com o aumento de $Z$ há uma diminuição do tamanho do subgrão.

Além destes parâmetros a condição do material de base pode influenciar a microestrutura resultante. Etter et al. ${ }^{(90)}$ observaram o mecanismo de recristalização dinâmica na solda por SALM para uma liga de alumínio deformada e o mecanismo de recristalização contínua na solda de uma liga recozida. Não foram feitas considerações sobre a influência destes mecanismos na textura resultante do cordão.

\subsection{Textura no SALM}

Um material apresenta anisotropia quando as propriedades físicas e mecânicas medidas em direções cristalográficas diferentes apresentam valores diferentes. A maioria dos monocristais é anisotrópico. Considerando-se um material como um 
conjunto de monocristais dispostos ao acaso, a anisotropia de cada cristal pode ser compensada obtendo-se um material de propriedades isotrópicas. Industrialmente, esta condição é muito difícil de ser obtida e no processamento o material adquire uma orientação preferencial que é chamada de textura ${ }^{(91)}$.

A deformação na laminação do alumínio e suas ligas na temperatura ambiente ocorre pela movimentação de discordâncias nos planos $\left\{\begin{array}{lll}1 & 1 & 1\end{array}\right)$ e direções $<110>$. A deformação nestes planos e direções produz um alinhamento cristalográfico dos grãos em relação à direção de laminação ${ }^{(92)}$. Após processos de conformação do alumínio e suas ligas, a textura resultante é função do tipo e da temperatura de

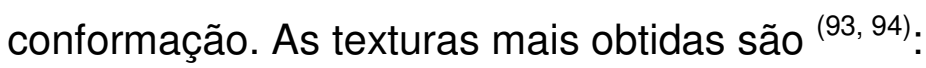

- Tipo cobre, $\left\{\begin{array}{lll}1 & 1 & 2\end{array}\right\}\left(\begin{array}{lll}1 & 1 & 1\end{array}\right) ;$

- Tipo latão, $\left\{\begin{array}{llll}1 & 1 & 0\end{array}\right\}\left\langle\begin{array}{lll}1 & 1 & 2\end{array}\right) ;$

- Tipo Goss, $\left\{\begin{array}{llll}0 & 1 & 1\end{array}\right\}\left(\begin{array}{lll}1 & 0 & 0\end{array}\right)$;

- Tipo S, $[123)(634) ;$

- Tipo cubo, $\left[\begin{array}{lll}1 & 0 & 0\end{array}\right\}\left\langle\begin{array}{lll}0 & 0 & 1\end{array}\right\rangle$

Para o estudo da textura utiliza-se o auxílio da função distribuição de orientação (FDO) dos grãos. Estas funções especificam a freqüência de ocorrência de determinadas orientações em um espaço tridimensional. Este espaço é definido por três ângulos de Euler: $\varphi_{1}, \Phi, \varphi_{2}$. A FDO pode ser calculada através das informações adquiridas pela técnica de EBSD.

A figura 26 mostra a localização das componentes mais importantes de textura de laminação no espaço de Euler. 
(a)

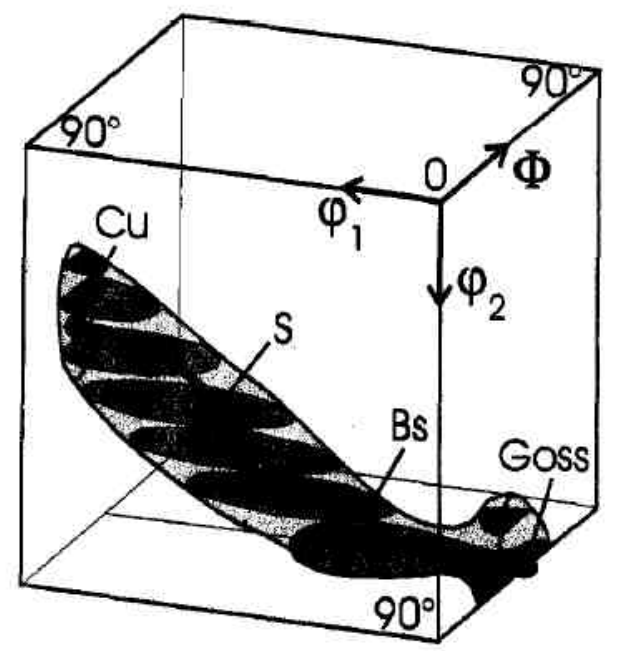

(b)

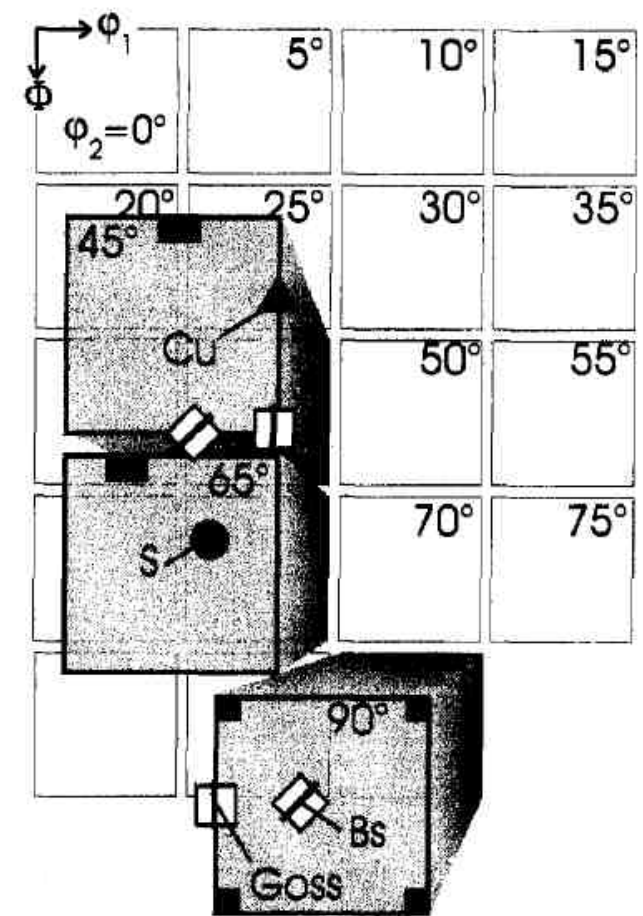

Figura 26 - a) Componentes de textura de laminação de metais CFC no espaço de Euler em 3D: a fibra $\beta$ entre a componente cobre e latão e a fibra $\alpha$ entre a componente do tipo latão e Goss. b) As seções constantes $\varphi_{2}{ }^{(95)}$.

A textura resultante também pode ser influenciada pela recristalização do material, removendo completamente a textura ou acentuando alguns de seus componentes $(60,96,97)$.

Karlsen et al ${ }^{(83,98)}$ obtiveram, através de análises de EBSD nas regiões do centro do cordão, região de retrocesso e região de avanço, texturas muito pronunciadas, como está ilustrado na figura 27. O centro do cordão e a região de avanço apresentaram uma microestrutura com presença de grãos predominantemente de alto ângulo. A região de retrocesso apresentou uma quantidade maior de subgrãos. Tratamentos térmicos realizados nesta microestrutura a 500 ㅇ por uma hora apresentaram componentes de textura diferentes doas apresentados na condição como soldada. 
a)
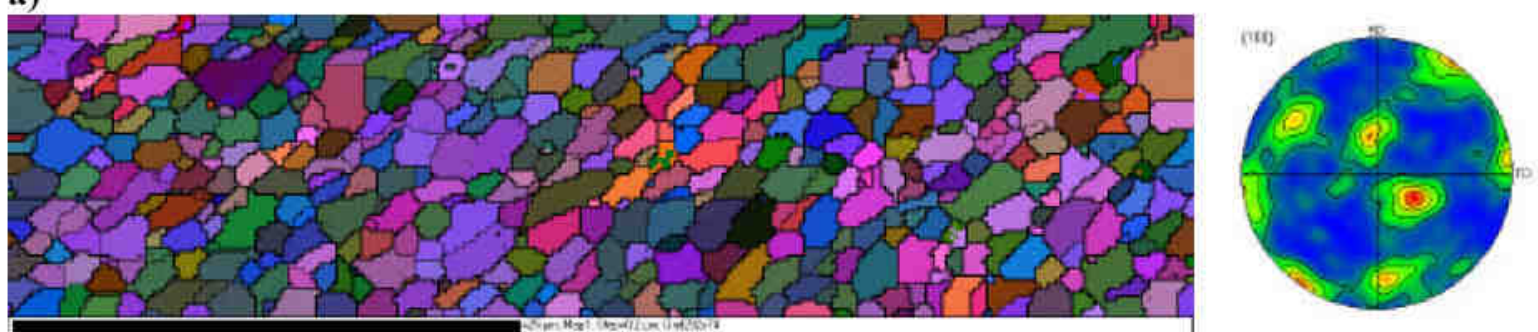

b)
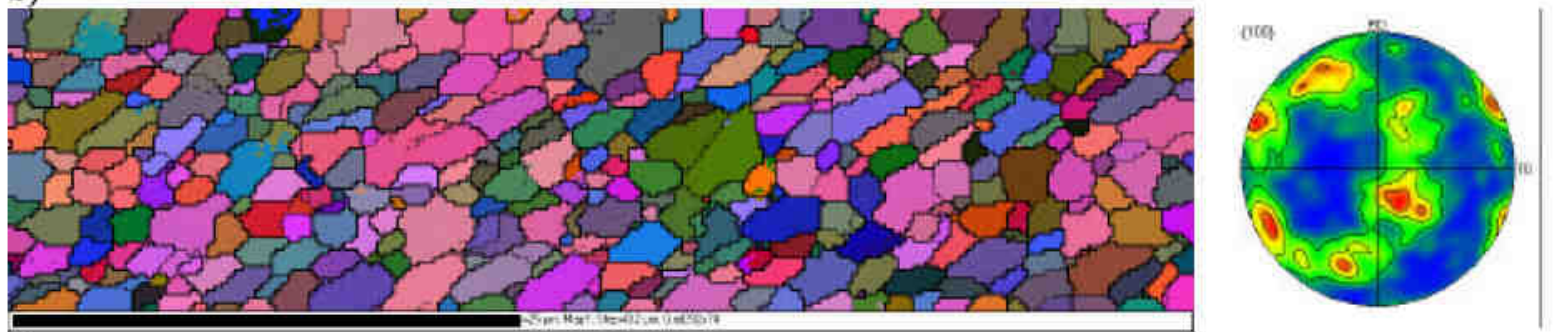

c)
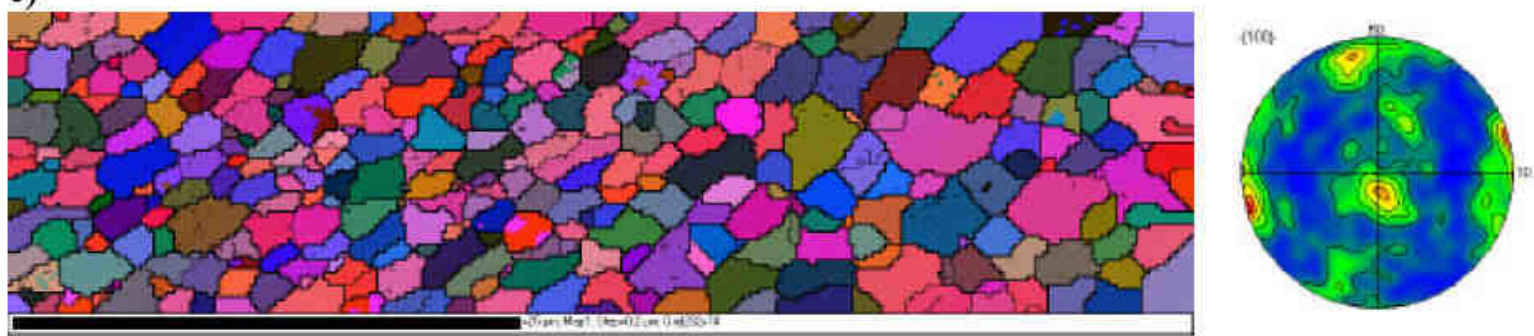

Figura 27 - Mapas EBSD e figuras de pólo $<10$ 0 0 na condição como soldado, a) b) e c) referem-se a três regiões no centro do cordão na região do onion ring ${ }^{(83)}$. 


\section{OBJETIVOS}

Os objetivos deste trabalho são:

- caracterizar a microestrutura, a textura e as propriedades mecânicas resultantes das condições estudadas do processo SALM para a ligas de alumínio e sua evolução com diferentes tratamentos térmicos (solubilização, solubilização e envelhecimento e recozimento).

- avaliar o efeito de um segundo cordão no mesmo sentido e em sentido oposto nas propriedades mecânicas finais, textura e microestrutura do material.

- entender os fenômenos de crescimento de grão nas ligas de alumínio nas regiões de avanço e retrocesso do cordão de solda para as diferentes condições de soldagem e tratamentos térmicos pós soldagem . 


\section{MATERIAIS E MÉTODOS}

\subsection{Metal de base}

Foram confeccionados seis corpos de prova de alumínio extrudado AA $6063 \mathrm{com}$ $3 \mathrm{~mm}$ de espessura $150 \mathrm{~mm}$ de largura e $250 \mathrm{~mm}$ de comprimento, com a composição química dada na tabela 4:

Tabela 4 - Composição química dos corpos de prova

\begin{tabular}{cccccccccc}
\hline Si & $\mathbf{F e}$ & $\mathbf{C u}$ & $\mathbf{M n}$ & $\mathbf{M g}$ & $\mathbf{C r}$ & $\mathrm{Ti}$ & $\mathbf{V}$ & $\mathbf{B}$ & $\mathbf{G a}$ \\
0,408 & 0,180 & 0,020 & 0,085 & 0,482 & 0,003 & 0,021 & 0,006 & 0,002 & 0,012 \\
\hline
\end{tabular}

\subsection{Soldagem dos corpos de prova}

A junta foi soldada topo-a-topo no comprimento de $250 \mathrm{~mm}$, paralelo a direção de extrusão do corpo de prova. Em seguida foi soldado outro cordão na mesma direção do primeiro e outro na direção contrária do primeiro.

A soldagem dos corpos de prova foi realizada com controle de posição em máquina comercial com ferramenta tipo 'three flats', com $15 \mathrm{~mm}$ de diâmetro do ombro e $5 \mathrm{~mm}$ de diâmetro do pino. O ângulo da ferramenta foi de $0^{\circ}$. A velocidade de rotação foi de $710 \mathrm{rpm}$ e velocidade de translação de $5,3 \mathrm{~mm} / \mathrm{s}$.

A máquina utilizada está localizada no IST-Universidade Técnica de LisboaDepartamento de Engenharia Mecânica.

A figura 28 apresenta um cordão soldado e o detalhe do tipo da ferramenta utilizada. A região com o furo é a saída da ferramenta e o fim do cordão. 


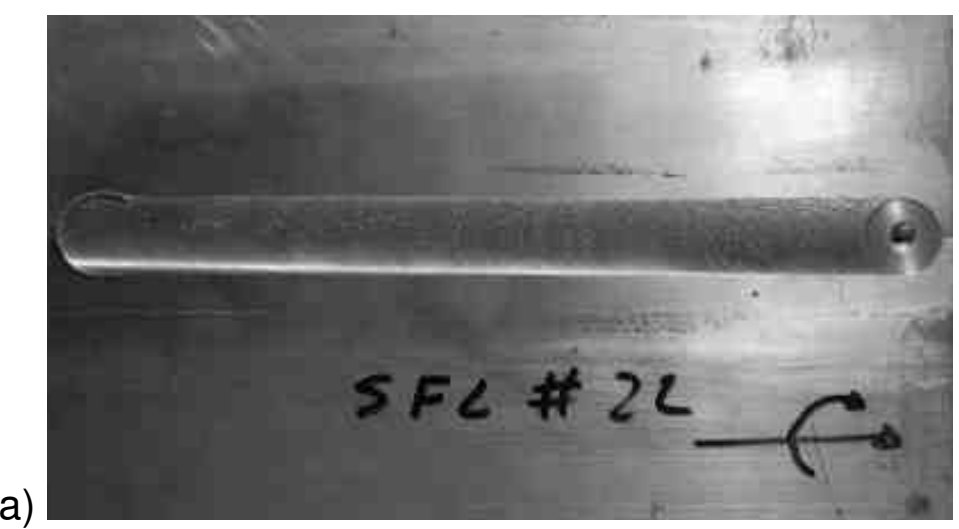

b)

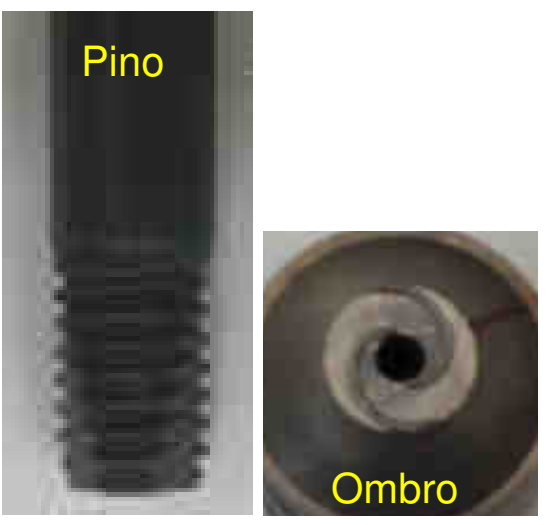

Figura 28 - a) Fotografia do cordão soldado com um passe. As setas indicam a direção e rotação da ferramenta. b) Detalhe do tipo do pino e ombro da ferramenta utilizada.

A figura 29 ilustra as diferentes condições de soldagem realizadas descritas.

a) 1 passe

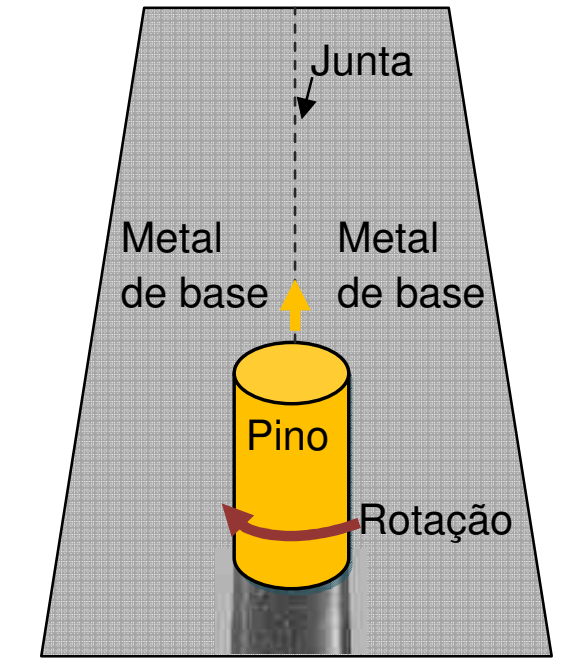

Avanço b) 2 passes sem inversão

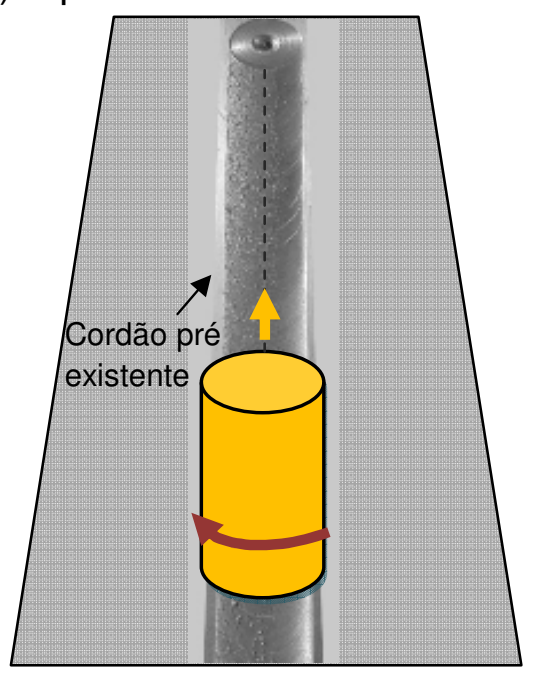

c) 2 passes com inversão

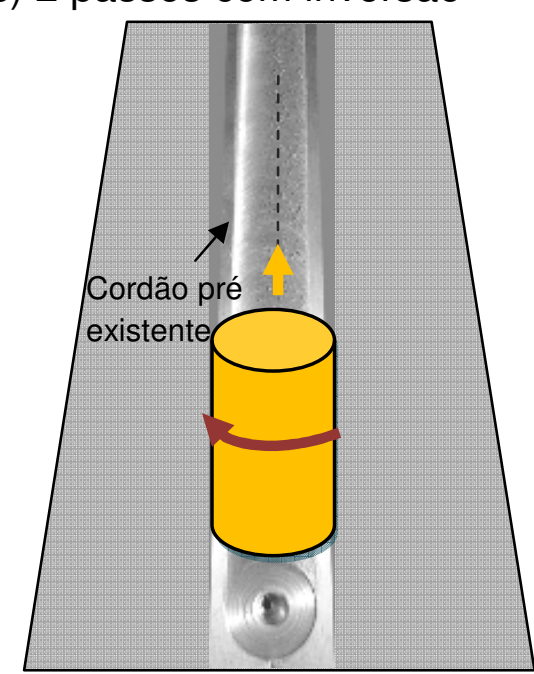

Figura 29 - Diferentes condições de soldagem. a) 1 passe b) 2 passes na mesma direção c) dois passes com direção inversa de rotação do pino.

A figura 30 ilustra as diferentes posições de análise do cordão, com a nomenclatura que será utilizada ao longo deste trabalho. A vista superior e a vista de raiz foram realizadas à $0,075 \mathrm{~mm}$ de profundidade. 


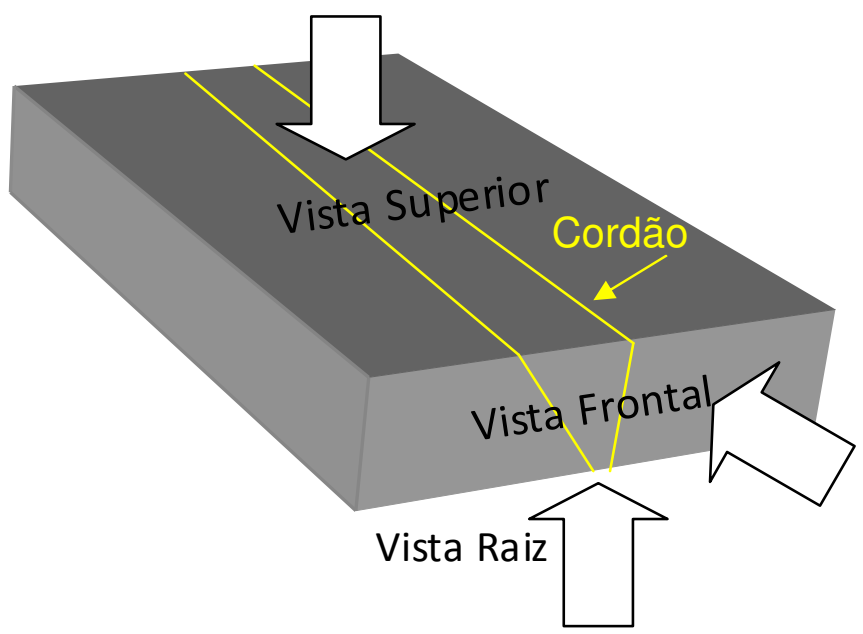

Figura 30 - Regiões de análise do cordão de solda por SALM.

\subsection{Preparação das amostras para microscópio ótico}

A retirada de amostras dos corpos de prova foi realizada com serra tico-tico de mesa, procurando-se aquecer o mínimo possível durante o corte. As amostras cortadas foram então seccionadas em cortadeira refrigerada com disco abrasivo. Devido às baixas temperaturas de recuperação do alumínio, as amostras foram embutidas a frio com resina de marca Struers EPOFIX, com tempo de cura de 24 horas.

Após a cura da resina seguiu-se para o lixamento na seqüência de granas 180, 220, 400 , e finalmente 600 . Após o lixamento foi realizado o polimento com material para polimento de não ferrosos de marca comercial BRASSO em pano para polimento típico para abrasivos de $3 \mu \mathrm{m}$. Após este polimento foi realizado um polimento intermediário com diamante em suspensão de $1 \mu \mathrm{m}$. O polimento final foi realizado com sílica.

Após isto as amostras foram anodizadas com solução de Barker (1,8\% ácido fluobórico) durante 4 minutos numa tensão de 20 volts. 
Para a análise das micrografias utilizou-se um microscópio ótico Olympus modelo BX51RF com câmera Olympus DP12 e luz polarizada.

\subsection{Preparação das amostras para calorimetria diferencial}

As amostras foram cortadas em cortadeira tipo Isomet da marca Buehler com disco diamantado. O calorímetro necessita de amostras de $20 \mathrm{mg}$ de massa. Assim, as dimensões cortadas das amostras visavam este peso com excesso aproximado de 8 mg. Este excesso foi removido através do lixamento com lixa d'água grana 600 e repetidas pesagens em balança de precisão de marca OHAUS.

Foram retiradas amostras do centro do cordão e da região adjacentes ao centro distanciado pela espessura do corte da ordem de 1,3 $\mathrm{mm}$, sendo estas as regiões de avanço e retrocesso do SALM.

Após a correção dos pesos as amostras foram lavadas em ultrasom em solução alcoólica e embaladas até o ensaio no calorímetro.

\subsection{Preparação das amostras para EBSD e MEV}

As amostras foram cortadas em cortadeira tipo Isomet da marca Buehler com disco diamantado. As secções escolhidas foram embutidas a frio em resina Struers EPOFIX. Em seguida as amostras foram lixadas na seqüência de granas 180, 220, 400 e 600 . Após o lixamento foi realizado o polimento com material para polimento de não ferrosos de marca comercial BRASSO em pano para polimento típico para abrasivos de $3 \mu \mathrm{m}$. Após este polimento foi realizado um polimento intermediário com diamante em suspensão de $1 \mu \mathrm{m}$. O polimento final foi realizado com sílica coloidal. 
O EBSD foi realizado em microscópio eletrônico de varredura Philips XL-30, do Departamento de Engenharia Metalúrgica e de Materiais da EPUSP, que utiliza filamento de tungstênio.

\subsection{Tratamento térmico nos cordões (1 passe e 2 passes)}

Os tratamentos térmicos foram realizados em fornos da marca Grion com aquecimento por resistência. Os corpos de prova na condição como soldada (CS) foram colocados no forno somente após o forno atingir a temperatura desejada.

O recozimento, a solubilização e o envelhecimento foram realizados nos tempos e temperaturas indicadas na tabela 5 . Os corpos de prova envelhecidos foram previamente solubilizados e o tratamento de recozimento foi realizado em dois tempos diferentes em amostras diferentes.

Tabela 5 - Tempos e Temperaturas de Tratamento Térmico

\begin{tabular}{cccc}
\hline Tratamento & Temperatura (K) & Tempos (h) & \\
\hline Envelhecimento (E) & 453 & & 8 \\
\hline Recozimento (R) & 623 & 2 & 8 \\
\hline Solubilização (S) & 863 & 2 & \\
\hline
\end{tabular}

Após o tratamento os corpos de prova foram resfriados imediatamente em água na temperatura ambiente e armazenados numa temperatura próxima a $279 \mathrm{~K}$.

Assim, foram produzidas amostras dos cordões nas condições recozido durante duas horas, recozido durante oito horas, solubilizado e envelhecido com solubilização prévia. 


\subsection{Caracterização dos cordões soldados}

\subsubsection{Microscopia óptica}

Com a microscopia óptica, utilizando-se do ataque de Barker, foram realizadas as medidas de tamanho de grão de diferentes regiões do cordão através do método dos interceptos. Foi utilizado um círculo teste e um aumento que permitisse uma contagem mínima de 10 e máxima de 35 interceptos. O procedimento encontra-se descrito na ASTM E 112. Foram medidos 5 campos para obter um tamanho de grão médio $\overline{T G}$. A equação (11) apresenta o cálculo para o tamanho de grão médio.

$$
\overline{T G}=\frac{\sum_{i=1}^{n} \frac{1}{\left(N_{L}\right)_{i}}}{n}
$$

O desvio-padrão das medidas de tamanho de grão médio foram realizadas através da equação (12).

$$
\sigma(\bar{x})=\sqrt{\frac{\sum_{i=1}^{n-1}\left(T G_{i}-\overline{T G}\right)^{2}}{n-1}}
$$

Nos cordões na condição como soldado e recozido foram realizadas duas medidas de tamanho de grão na região termomecanicamente afetada: uma na região com grãos predominantemente equiaxiais e outra nos grãos achatados nos lados de 
avanço e retrocesso. Nas outras condições foram realizadas as medidas nos lados de avanço e retrocesso e no meio do cordão.

As áreas com recristalização secundária nos corpos de prova recozidos também foram avaliadas através do software Zeiss AxioVision.

As imagens obtidas foram processadas em software gráfico para a melhoria do contraste e brilho e também para a montagem de seqüências de fotos.

Após as montagens foram medidas as áreas da zona termomecanicamente afetada no avanço e no retrocesso, na vista frontal dos cordões. A figura 31 apresenta esquematicamente a metodologia utilizada.

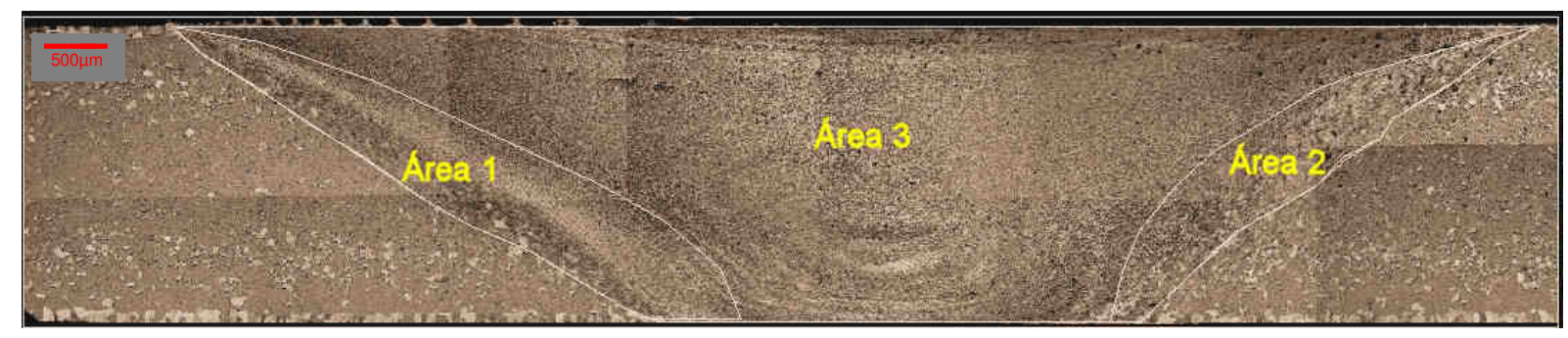

Figura 31 - Esquema das medidas das áreas da zona termomecanicamente afetada na vista frontal do cordão de solda. A soma das áreas indicadas corresponde a área total do cordão. As áreas 1 e 2 correspondem a ZTMA.

\subsubsection{Microscopia eletrônica}

Foi utilizada a técnica de análise de EBSD com microscópio eletrônico de varredura. Na técnica os padrões Kikuchi, que fornecem os dados sobre a rede cristalina, são captados por uma câmera de alta resolução. A imagem passa por um processamento digital que permite calcular e identificar as linhas paralelas às bandas de Kikuchi. Assim, a microestrutura é descrita com dados com representação estatística obtendo informações de microtextura e mesotextura

O EBSD foi utilizado para avaliar simultaneamente a orientação dos grãos em diferentes regiões dos cordões realizados nesta tese, os tamanhos de grão e a 
evolução da textura na região de retrocesso, avanço e centro do cordão nos diferentes tratamentos térmicos posteriores.

\subsubsection{Ensaios de Microdureza}

O perfil de dureza foi realizado em microdurômetro Vickers com uma carga de 50 gramas. O perfil foi levantado através de medidas consecutivas ao longo de uma linha perpendicular a direção de soldagem. A distância entre cada medida foi de 1 $\mathrm{mm}$ e foram realizadas duas indentações para cada medida do perfil.

\subsubsection{Ensaios de Calorimetria Diferencial}

Os dados fornecidos pelo calorímetro foram tratados no software Matlab em algoritmo próprio desenvolvido para subtrair a curva padrão do calorímetro e para identificar os picos de energia em determinada temperatura e as inflexões da curva de energia.

Os cálculos das energias de ativação foram realizados através do método de Kissinger ${ }^{(99)}$. Segundo este método, a temperatura mínima $\left(T_{c}\right)$ para a reação é dependente da velocidade de aquecimento, de acordo com a equação (13):

$$
d \frac{\ln \frac{s}{T_{c}^{2}}}{\frac{1}{T_{e}}}=-\frac{Q}{R}
$$

Segundo a equação (13), o gráfico de $\ln \frac{x}{\tau_{\varepsilon}^{2}}$ por $\frac{1}{\tau_{\varepsilon}}$ resulta em uma reta com inclinação $-\frac{Q}{R}$. 
Foram utilizadas as velocidades de aquecimento de $0,17 \mathrm{~K}^{-\mathrm{s}^{-1}} ; 0,33 \mathrm{~K} \cdot \mathrm{s}^{-1}$ e $0,5 \mathrm{~K} \cdot \mathrm{s}^{-1}$ nos ensaios em atmosfera de nitrogênio, para o cálculo de cada energia de ativação aparente nas diferentes transformações de fase presentes na liga AA 6063.

\subsection{Experimentação Estatística}

Experimentos são realizados por pesquisadores praticamente em todas as áreas de pesquisa geralmente para descobrir algo particular sobre um processo ou sistema $(100,101,102)$. Um experimento é um teste, ou uma seqüência de testes para descobrir a relação entre as variáveis do ensaio e o resultado obtido.

A experimentação estatística ajuda a planejar e conduzir os testes e analisar os resultados para se obter conclusões objetivas ${ }^{(100)}$. No delineamento de um experimento define-se o ensaio experimental como o arranjo dos equipamentos para funcionarem sob condições específicas. O dado experimental é uma medida numérica que descreve a conseqüência do ensaio e o erro experimental como a variação dos resultados para as mesmas condições de ensaio.

Um tipo comum de experimentação é a comparação de duas amostras quanto às suas médias ou suas variâncias. Para ajudar nestas comparações são utilizados os testes estatísticos e de hipótese.

No delineamento estatístico de um experimento é fundamental a correta definição dos seguintes itens:

- Variável de Resposta: É a saída do experimento, uma característica mensurável de qualidade ou desempenho. Um experimento pode ter uma ou mais variáveis de resposta. 
- Fator: É uma variável que é modificada de maneira intencional e controlada, para verificar o seu impacto numa variável de resposta. $O$ fator pode ser tanto qualitativo, como por exemplo, máquinas $\mathrm{A}, \mathrm{B}$ e $\mathrm{C}$ ou quantitativo, como por exemplo, temperaturas $550^{\circ} \mathrm{C}$; $400{ }^{\circ} \mathrm{C}$ e $250 \stackrel{\circ}{\circ} \mathrm{C}$.

- Variável de Bloco: Também conhecido como ruído. Variáveis de bloco são variáveis que aparecem no experimento de forma indireta. Variáveis típicas de bloco são lotes de ensaio, corridas de material, turnos de trabalho, operadores, instrumentos, entre outros. Estas variáveis podem ser controladas nos experimentos através da técnica de blocos. Nos blocos espera-se que a variação dentro do bloco seja inferior do que a variação entre os blocos.

- Nível: Um valor específico de uma variável quantitativa, ou determinada opção de uma variável qualitativa, que estão inclusas no experimento. Os níveis devem ser fixados em valores de interesse.

- Efeito: A mudança na variável de resposta que ocorre com a mudança dos níveis das variáveis ou blocos. O efeito pode ser descrito como linear, exponencial, ou de interação com outros fatores.

- Ruído: Variável que não se tem conhecimento, ou que se espera que tenha praticamente nenhuma influência no efeito estudado.

$\mathrm{Na}$ elaboração de um experimento cria-se uma matriz de experimentos que auxilia na definição correta dos itens acima. A figura 32 ilustra uma matriz de experimentos onde os fatores estão descritos na primeira coluna e na primeira linha da matriz. A linha e a coluna seguinte especificam os níveis destes fatores. Os resultados obtidos para as variáveis de resposta são armazenados na matriz conforme a condição de 
ensaio determinada pelos dois fatores. Assim, a matriz de experimentos é o planejamento para a realização dos testes. Cada ensaio a ser feito, cada medição a ser realizada deve estar identificada na matriz.

\begin{tabular}{|c|c|c|c|c|c|}
\hline \multicolumn{2}{|c|}{} & \multicolumn{2}{c|}{ Pressão 1 } & \multicolumn{2}{c|}{ Pressão 2 } \\
\cline { 2 - 6 } & Temp 1 & Temp 2 & Temp 1 & Temp 2 \\
\hline \multirow{2}{*}{ Lote 1 } & Carga 1 & $\# 6$ & $\# 2$ & $\# 8$ & $\# 15$ \\
\cline { 2 - 6 } & Carga 2 & $\# 11$ & $\# 13$ & $\# 4$ & $\# 7$ \\
\hline \multirow{2}{*}{ Lote 2 } & Carga 1 & $\# 10$ & $\# 9$ & $\# 5$ & $\# 12$ \\
\cline { 2 - 6 } & Carga 2 & $\# 14$ & $\# 1$ & $\# 16$ & $\# 3$ \\
\hline
\end{tabular}

Figura 32 -Matriz de experimentos com dois fatores: Pressão e Lote e dois níveis por fator. Os números dentro da matriz indicam a seqüência de ensaios.

A repetição dos ensaios, ou replicação, nas mesmas condições experimentais é importante para avaliar a influência dos ruídos nos efeitos e assim determinar o erro experimental. Existem diversos tipos de replicações:

- Repetição de medições para as mesmas amostras;

- Diversas amostras para as mesmas combinações de fatores;

- Repetição parcial da matriz de testes;

- Repetição completa da matriz de testes.

Quando a replicação dos testes não for possível pode-se identificar o erro experimental como os fatores de pouca influência no experimento ${ }^{(100)}$. 
Devem ser escolhidas diferenças amplas entre os níveis mais baixos e mais altos dos fatores, garantindo assim que os efeitos sejam significativos em relação às variáveis de ruído. Porém, não devem ser muito distantes, pois não sabe se entre os dois níveis há descontinuidades ou um comportamento não linear.

O experimento com o menor número de fatores é o experimento comparativo que apresenta um fator, dois níveis e um bloco sempre ${ }^{(102)}$. O bloco do experimento comparativo é criado pelo par que se deseja comparar, como por exemplo, dois cordões de solda do mesmo processo, ou dois lotes de ferramentas.

A grande parte dos experimentos envolve a análise de dois ou mais fatores. Estes experimentos são conhecidos também como arranjos fatoriais.

Os arranjos fatoriais garantem que todas as combinações de níveis e fatores sejam investigadas. A figura 33 apresenta um arranjo fatorial de dois fatores e dois níveis com seus resultados de forma gráfica.

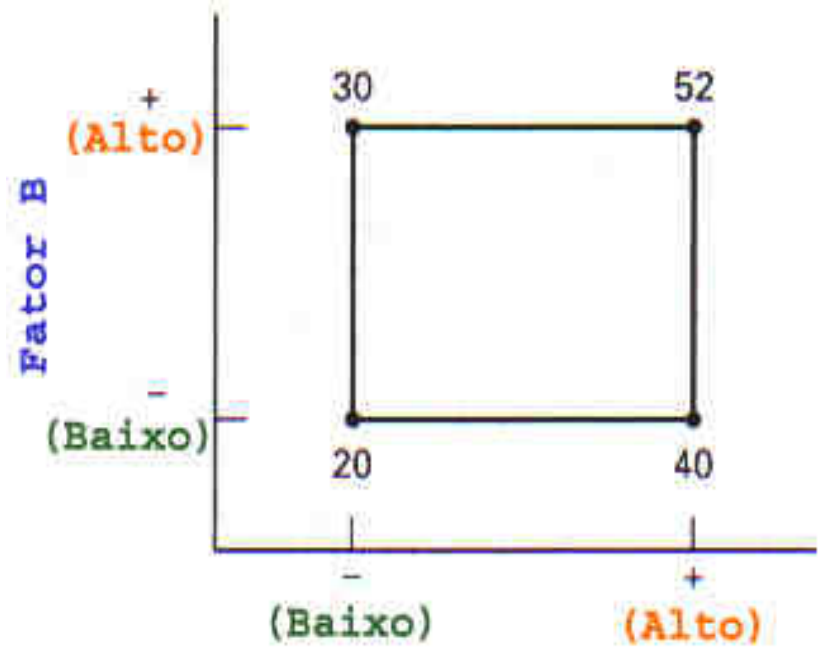

Fator A

Figura 33 - Arranjo fatorial de dois fatores com dois níveis ${ }^{(100)}$.

Os efeitos dos fatores A e B podem ser verificados através das equações (14) e (15), respectivamente: 


$$
\begin{aligned}
& \mathrm{A}=((40+52) / 2)-((20+30 / 2)=21 \\
& \mathrm{B}=((30+52) / 2)-((20+40 / 2)=11
\end{aligned}
$$

Desta análise de influências pode se concluir que o aumento médio no efeito devido ao fator $\mathrm{A}$ foi de 21 unidades e o aumento médio no efeito devido à $\mathrm{B}$ foi de 11 unidades. $O$ teste estatístico utilizando a distribuição $F$ pode ser aplicado nestes resultados, caso houvesse mais uma replicação, para se verificar qual influência é significativa diante da variação total do experimento e seu erro. As interações entre os fatores A e B podem ser verificadas através das equações (16) e (17).

Para o nível baixo do fator $\mathrm{B}$ o efeito de $\mathrm{A}$ é dado por:

$$
A=40-20=20
$$

Para o nível alto do fator $\mathrm{B}$ o efeito de $\mathrm{A}$ é dado por:

$$
A=52-30=22
$$

O efeito de interação de $A$ com B neste caso não é significativo. A figura 34 apresenta um gráfico do efeito da interação. Interações significativas apresentam uma inversão nos efeitos, como demonstrado pelas retas que se cruzam. 
a)

\section{SEM INTERAÇÃO}

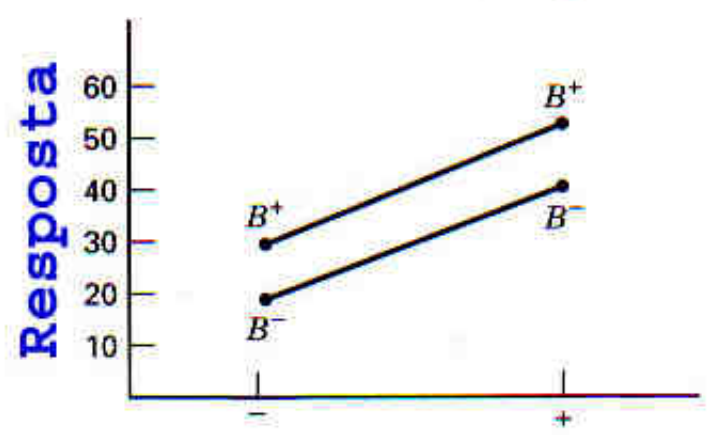

Fator A b)

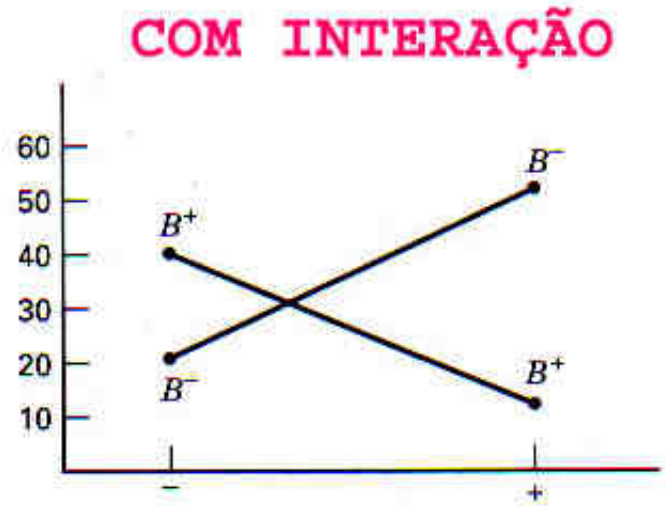

Fator A

Figura 34 - Gráfico dos efeitos de interação. Os símbolos + e - indicam o nível do fator no máximo e no mínimo. (a) Fator A sem interação com Fator $B$ (b) Fator A com interação com Fator $B^{(100)}$.

Para dois fatores com mais níveis utiliza-se a tabela de análise variância ANOVA para a avaliação dos efeitos dos fatores. A figura 35 apresenta uma matriz de experimentos de dois fatores com a e b níveis e $n$ replicações.

\section{FATOR B}

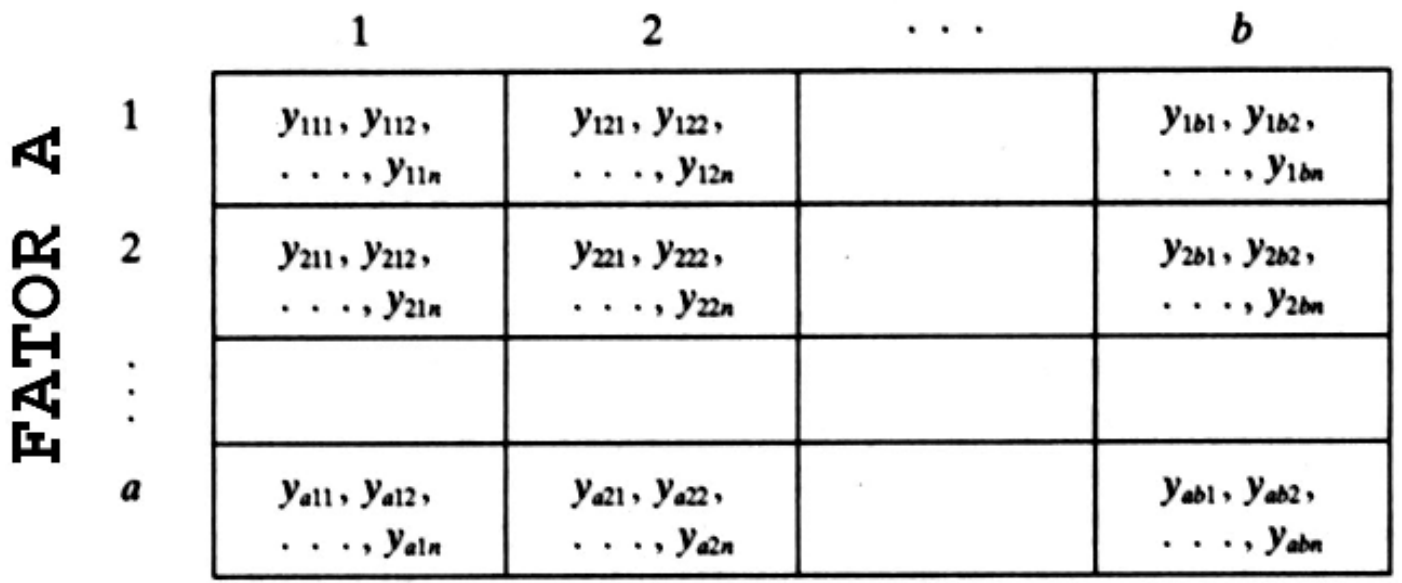

Figura 35 - Matriz de experimentos de dois fatores com $a$ e $b$ níveis e $n$ replicações, $y=$ resposta ${ }^{(100)}$. 
A tabela 6 apresenta os cálculos para avaliar a influência dos efeitos. Quando a distribuição $F_{0}$ calculada é superior ao $F$ tabelado previsto, considera-se o efeito do tratamento, ou sua interação, como significativo.

A soma dos quadrados, que indica a variância, dos efeitos e do erro é calculada pelas equações (18) a (21):

$$
\begin{gathered}
S S_{a}=b \times n \times \sum_{i=1}^{a}\left(\bar{y}_{\text {média linha } i}-\bar{y}_{\text {média geral }}\right)^{2} \\
S S_{b}=a \times n \times \sum_{i=1}^{b}\left(\bar{y}_{\text {média coluna } i}-\bar{y}_{\text {média geral }}\right)^{2} \\
S S_{a b}=n \times \sum_{i=1}^{a} \sum_{j=1}^{b}\left(\bar{y}_{\text {média ensaio } i j}-\bar{y}_{\text {média linha } i}-\bar{y}_{\text {média coluna } j}+\bar{y}_{\text {média geral }}\right)^{2} \\
S S_{E}=\sum_{i=1}^{a} \sum_{j=1}^{b} \sum_{k=1}^{n}\left(y_{i j k}-\bar{y}_{\text {média do ensaio } i j}\right)^{2}
\end{gathered}
$$

Tabela 6 - Tabela de Análise de Variância ANOVA. Adaptado de ${ }^{(100,102)}$

\begin{tabular}{lcccc}
\hline $\begin{array}{l}\text { Fonte de } \\
\text { Variação }\end{array}$ & $\begin{array}{c}\text { Soma dos } \\
\text { Quadrados }\end{array}$ & $\begin{array}{c}\text { Graus de } \\
\text { Liberdade }\end{array}$ & $\begin{array}{c}\text { Quadrados } \\
\text { Médios }\end{array}$ & $\begin{array}{c}F_{0} \\
\text { (Calculado) }\end{array}$ \\
\hline Tratamento A & $S S_{A}$ & $a-1$ & $M S_{A}=\frac{S S_{A}}{a-1}$ & $F_{0}=\frac{M S_{A}}{M S_{E}}$ \\
Tratamento B & $S S_{B}$ & $b-1$ & $M S_{B}=\frac{S S_{B}}{b-1}$ & $F_{0}=\frac{M S_{B}}{M S_{E}}$ \\
Interação A X B & $S S_{A B}$ & $(a-1)(b-1)$ & $M S_{A B}=\frac{S S_{A B}}{(a-1)(b-1)}$ & $F_{0}=\frac{M S_{A B}}{M S_{E}}$ \\
Erro & $S S_{E}$ & $a b(n-1)$ & $M S_{E}=\frac{S S_{E}}{a b(n-1)}$ & \\
Total & $S S_{T}$ & $a b n-1$ & & \\
\hline
\end{tabular}

É parte da análise a verificação dos resíduos, que são calculados à partir da equação (22): 


$$
e_{i j k}=y_{i j k}-\bar{y}_{\text {média do ensaio } i j}
$$

Os resíduos ajudam a identificar tendências e erros experimentais excessivos que podem ocorrer durante os testes.

Para os cálculos estatísticos realizados na experimentação foi utilizado o software de marca Minitab. 


\section{Resultados e Discussão}

Os resultados obtidos e a discussão dos resultados serão apresentados na seguinte ordem:

5.1 Caracterização Metalográfica

5.2 Difração de elétrons retroespalhados (EBSD)

5.3 Determinação das Energias de Ativação Aparente

5.4 Ensaios de Microdureza

\subsection{Caracterização Metalográfica}

A caracterização metalográfica dos cordões nas condições como soldado e tratado termicamente será feita através de medidas de geometria do cordão, da medida do tamanho de grão e a utilização de ataque colorido para observação das diferentes regiões do cordão de solda.

\subsubsection{Como soldado}

\subsubsection{Microestrutura}

As figuras 36 à 38 mostram as vistas frontais, superiores e de raiz dos três tipos de cordões produzidos por um passe e dois passes com a mesma direção de rotação do pino, e dois passes com a rotação do pino invertida. As micrografias mostram o material de base e o cordão na condição como soldado para as três condições de soldagem. 
(a)

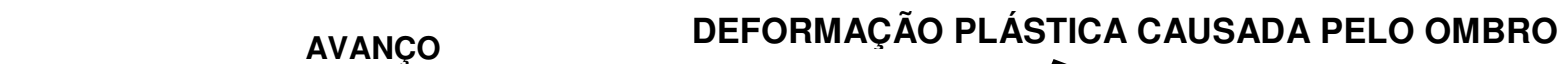

RETROCESSO

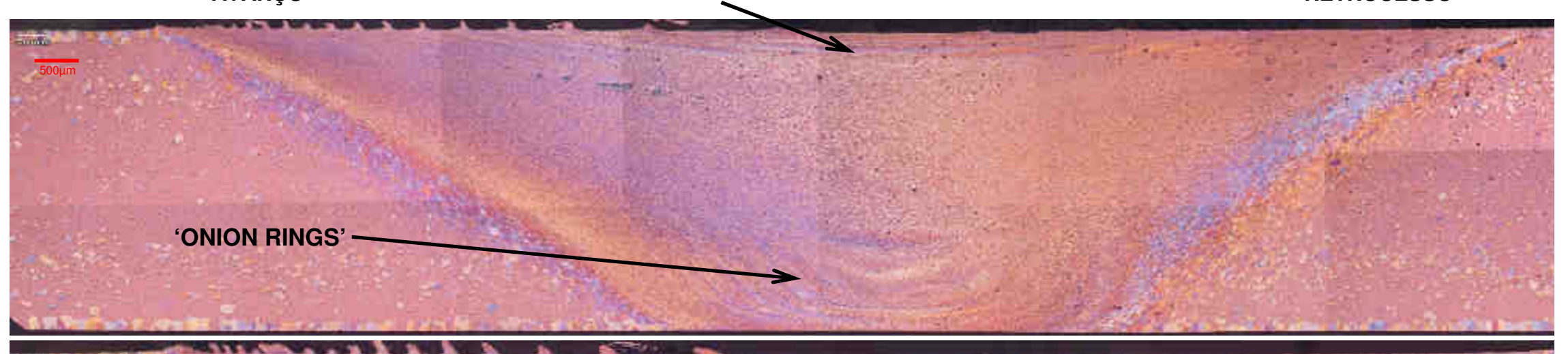

(b)

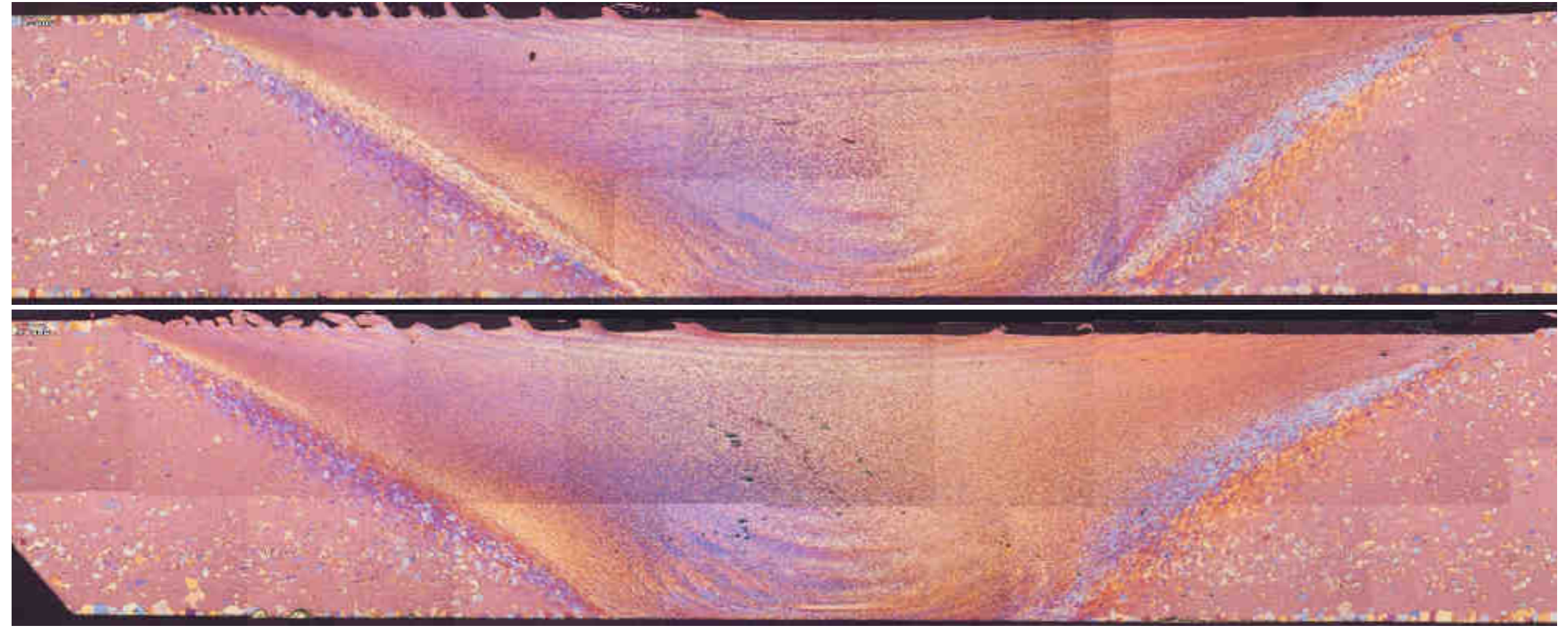

Figura 36 - Microestruturas frontais das seções dos cordões. (a) 1 passe Como Soldado (b) 2 passes sem inversão Como Soldado (c) 2 passes com inversão Como Soldado. Ataque: Barker 1,8\%. 
RETROCESSO

AVANÇO

(a)

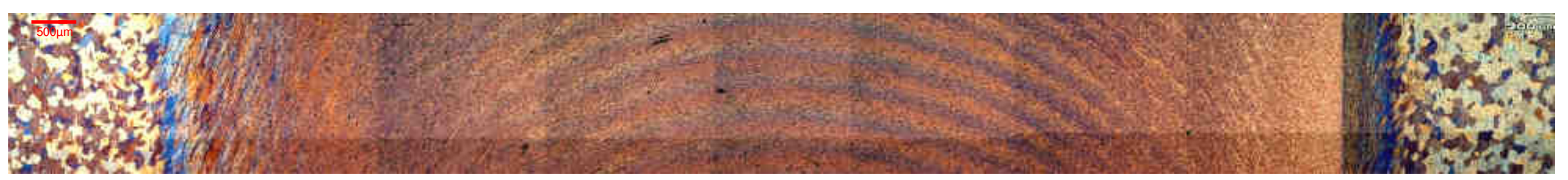

(b)

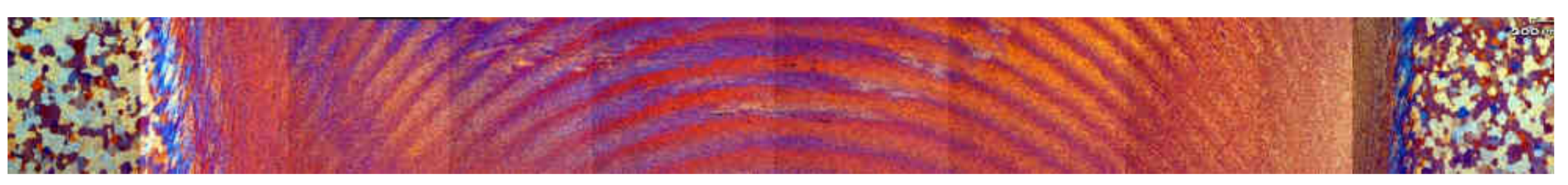

(c)

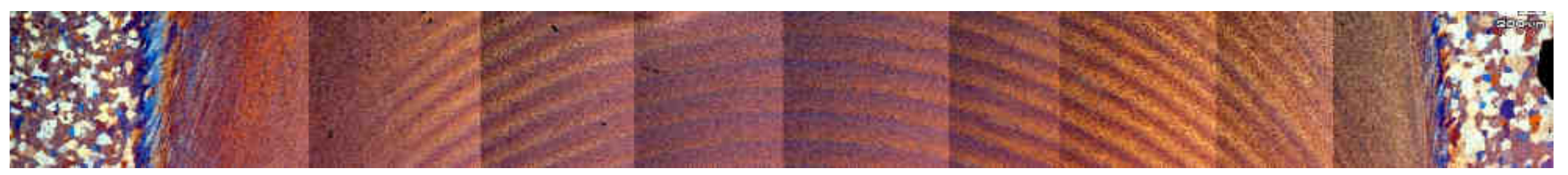

Figura 37 - Microestruturas da vista superior dos cordões. (a) 1 passe Como soldado (b) 2 passes sem inversão Como soldado (c) 2 passes com inversão Como soldado. Ataque: Barker 1,8\%. 
RETROCESSO

AVANÇO

(a)

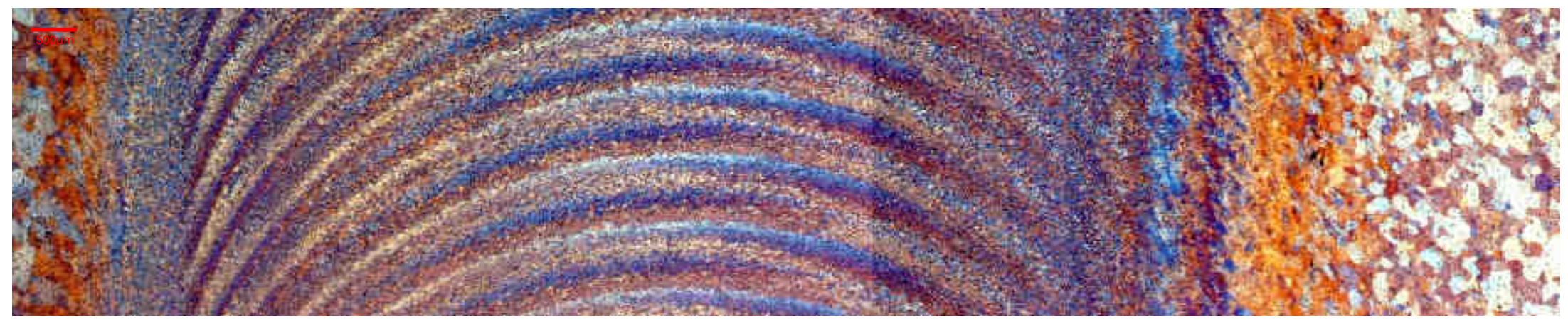

(b)

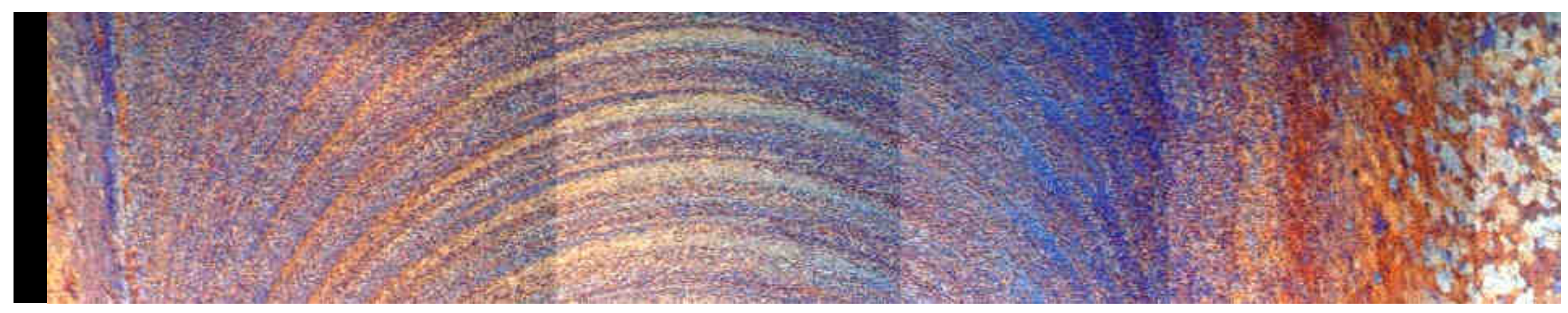

(c)

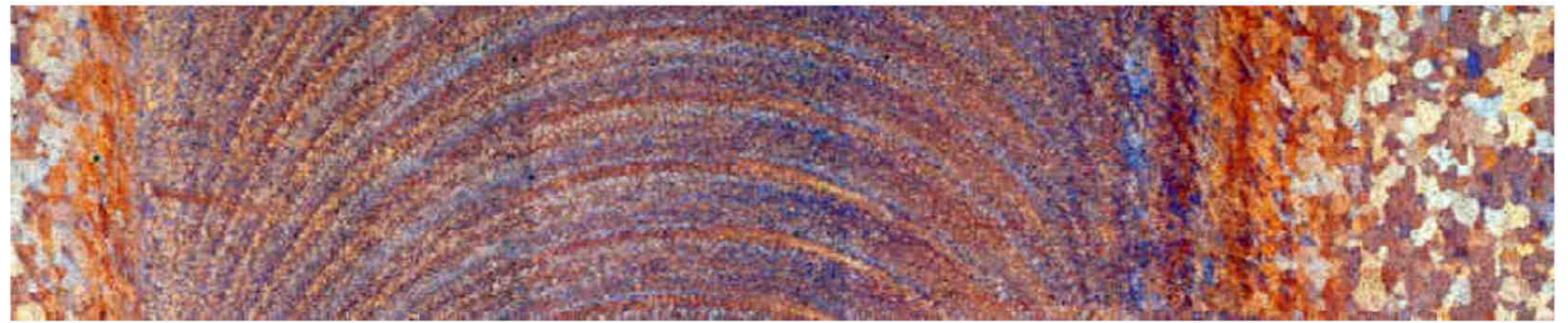

Figura 38 - Microestruturas da vista da raiz dos cordões. (a) 1 passe Como Soldado (b) 2 passes sem inversão Como Soldado (c) 2 passes com inversão Como Soldado. Ataque: Barker $1,8 \%$. 
Uma primeira análise mostra que os três cordões de solda não são simétricos, geometricamente, quando se compara os lados de avanço e retrocesso, como mostra a figura 31. Esta característica está relaciona com o fluxo de material, apresentado na figura 18.

$\mathrm{Na}$ vista frontal observa-se o cordão com as diferentes regiões características do processo SALM. No centro do cordão, nas três condições de soldagem, identifica-se a região do 'onion ring'. Adjacente a esta região localiza-se a região termomecanicamente afetada (ZTMA), caracterizada por grãos equiaxiais e predominantemente alongados na direção de rotação da ferramenta. Esta região apresenta uma coloração diferente na metalografia dos cordões.

As dimensões do cordão e suas áreas características se alteram com as condições ensaiadas. Para caracterizar estas diferenças foram feitas medições das áreas das regiões dos cordões (ZTMA) na vista frontal e as dimensões do cordão, para cada condição de soldagem, para o lado do avanço e o de retrocesso. As tabelas de 7 a 9 mostram estas medições e comparações entre elas.

Tabela 7 - Caracterização da geometria do cordão de solda na condição como-soldado. Vista Frontal.

\begin{tabular}{cccccc}
\hline $\begin{array}{c}\text { Condição de } \\
\text { soldagem }\end{array}$ & $\begin{array}{c}\text { Largura Topo } \\
(\mathrm{mm})\end{array}$ & $\begin{array}{c}\text { Largura Raiz } \\
(\mathrm{mm})\end{array}$ & $\begin{array}{c}\text { Área da ZTMA no } \\
\text { avanço }\left(\mathrm{mm}^{2}\right)\end{array}$ & $\begin{array}{c}\text { Área da ZTMA no } \\
\text { retrocesso }\left(\mathrm{mm}^{2}\right)\end{array}$ & $\begin{array}{c}\text { Área Total } \\
\left(\mathrm{mm}^{2}\right)\end{array}$ \\
\hline 1 Passe & 14,40 & 4,90 & 4,80 & 3,10 & 30,30 \\
\hline $\begin{array}{c}\text { 2 Passes sem } \\
\text { inversão }\end{array}$ & 14,85 & 5,30 & 4,90 & 3,00 & 32,30 \\
$\begin{array}{c}\text { 2 Passes com } \\
\text { inversão }\end{array}$ & 14,90 & 5,05 & 3,90 & 3,40 & 31,10 \\
\hline
\end{tabular}

Analisando-se a tabela 7 nota-se que existe uma diferença entre a largura do topo do cordão para as condições de soldagem estudadas. Da mesma maneira existe uma 
alteração na largura da raiz. Para quantificar estas diferenças foi construída a tabela 8. Nesta tabela as dimensões do cordão com 1 passe foi tomada como referência.

Tabela 8 - Razão entre larguras de topo e de raiz tendo como referência as dimensões do cordão com um passe para o cordão de solda na condição como-soldado e vista frontal.

\begin{tabular}{|c|c|c|c|c|}
\hline $\begin{array}{l}\text { Condição de } \\
\text { soldagem }\end{array}$ & $\begin{array}{l}\text { Largura Topo } \\
\qquad(\mathrm{mm})\end{array}$ & $\begin{array}{c}\text { Razão entre } \\
\text { larguras de topo } \\
(\%)\end{array}$ & Largura Raiz (mm) & $\begin{array}{c}\text { Razão entre larguras } \\
\text { de topo (\%) }\end{array}$ \\
\hline 1 Passe & 14,40 & - & 4,90 & - \\
\hline $\begin{array}{l}2 \text { Passes sem } \\
\text { inversão }\end{array}$ & 14,85 & 3,1 & 5,30 & 8,2 \\
\hline $\begin{array}{l}2 \text { Passes com } \\
\text { inversão }\end{array}$ & 14,90 & 3,5 & 5,05 & 3,1 \\
\hline
\end{tabular}

Com base nos resultados da tabela 8 nota-se que as razões das larguras de topo do cordão têm um pequeno aumento, que é praticamente igual para as duas condições onde foram empregados dois passes. Já para as razões das larguras de raiz notou-se um aumento de $8,2 \%$ quando foi realizado um segundo cordão no mesmo sentido que o primeiro, que foi reduzido para $3,1 \%$ quando o segundo cordão foi realizado em sentido contrário ao primeiro.

Estas diferenças estão relacionadas com as regiões apresentadas na figura 18. A pouca alteração na largura de topo pode estar relacionada com a deformação causada pelo ombro da ferramenta. Quando foi feito o primeiro cordão na chapa de AA6063-T6, devido ao aquecimento e aos fenômenos de solubilização de precipitados, recuperação e recristalização que ocorreram durante a soldagem em regiões do cordão, podem ter amolecido o material e, conseqüentemente, aumentado um pouco a largura de topo do cordão.

Com relação a largura de raiz, com base na figura 18, ocorre um fluxo de material da região II para a região IV (raiz) e , em seguida para a região I. Quando o segundo cordão 
é feito no mesmo sentido do primeiro, ele reforça o fluxo de material da região II para a região IV, aumentando esta região. Quando o sentido da ferramenta é invertido no segundo passe, o fluxo de material também é invertido, propiciando uma redução na largura de raiz. Comparando-se os dois modos com dois passes, houve um decréscimo de 8,2 para $3,1 \%$, quando o segundo passe foi no mesmo sentido e quando houve inversão de sentido, respectivamente.

Da mesma maneira foram analisadas as áreas da ZTMA de avanço e retrocesso, em relação à área total do cordão de solda. Os resultados estão apresentados na tabela 9.

Tabela 9 - Razão entre as áreas da ZTMA no avanço e no retrocesso tendo como referência a área total em cada condição de soldagem para o cordão de solda na condição como-soldado e vista frontal.

\begin{tabular}{cccccc}
\hline $\begin{array}{c}\text { Condição de } \\
\text { soldagem }\end{array}$ & $\begin{array}{c}\text { Área da ZTMA } \\
\text { no avanço } \\
\left(\mathrm{mm}^{2}\right)\end{array}$ & $\begin{array}{c}\text { Razão entre área } \\
\text { da ZTMA no } \\
\text { avanço e área } \\
\text { total }(\%)\end{array}$ & $\begin{array}{c}\text { Área da ZTMA } \\
\text { no retrocesso } \\
\left(\mathrm{mm}^{2}\right)\end{array}$ & $\begin{array}{c}\text { Razão entre área } \\
\text { da ZTMA no } \\
\text { retrocesso e área } \\
\text { total }(\%)\end{array}$ & $\begin{array}{c}\text { Área Total } \\
\left(\mathrm{mm}^{2}\right)\end{array}$ \\
\hline $\begin{array}{c}\text { 1 Passe } \\
\text { 2 Passes sem } \\
\text { inversão }\end{array}$ & $\mathbf{4 , 8 0}$ & $\mathbf{1 5 , 8}$ & 3,10 & $\mathbf{1 0 , 2}$ & 30,30 \\
\hline $\begin{array}{c}\text { 2 Passes com } \\
\text { inversão }\end{array}$ & $\mathbf{4 , 9 0}$ & $\mathbf{1 5 , 2}$ & 3,00 & $\mathbf{9 , 3}$ & 32,30 \\
\hline
\end{tabular}

Analisando-se a tabela 9 nota-se que existe uma diferença entre a ZTMA no lado do avanço e do retrocesso para as três condições de soldagem. Este resultado também está de acordo com o fluxo de material apresentado na figura 18.

No caso de um passe, a razão entre a área da ZTMA e a área total do cordão de solda do lado de avanço é 15,8\% maior que do lado do retrocesso, que é de 10,2\%. Comparandose a condição de soldagem com um passe com a condição com dois passes sem inversão, ocorre uma pequena redução na razão entre a área da ZTMA e a área total do cordão de solda no lado do avanço quando é feito o segundo cordão, reduz de $15 \%$ para 
15,2\%. Da mesma maneira, a razão entre a área da ZTMA e a área total do cordão de solda do lado de retrocesso para dois passes sem inversão de sentido foi ligeiramente menor, indicando que o fluxo de material feito duas vezes no mesmo sentido tendeu a reduzir um pouco as áreas das ZTMA's nesta condição. Quando se emprega um segundo cordão em sentido contrário ocorre uma redução na razão entre a área da ZTMA e a área total do cordão de solda do lado de avanço, devido ao fluxo de material que foi invertido, isto é a região que foi avanço no primeiro passe foi retrocesso no segundo e vice-versa. $O$ fluxo de material que vai da região II e região IV para a região I no lado do avanço é invertido, quando o sentido de rotação da ferramenta é invertido, no segundo passe. A tendência é ter ZTMA e cordão de solda mais simétrico que nas outras duas condições.

\subsubsection{Tamanho de grão}

O tamanho médio dos grãos no interior do cordão de solda é extremamente refinado quando comparado com o tamanho de grão do material de base. Na vista superior e na vista de raiz identificam-se, na região central, bandas de deformação ${ }^{(103)}$. Estas bandas também apresentam um tamanho de grão refinado e, entre esta região e o material de base, encontram-se as regiões afetadas termomecanicamente com grãos alongados na direção de rotação da ferramenta e do fluxo de material. Os grãos voltam a ser equiaxiais, porém com outro tamanho médio de grão, quando se parte da ZTMA para o metal base. A figura 39 ilustra o que foi descrito anteriormente para o lado de avanço de um cordão com um único passe.

A tabela 10 apresenta as medições dos tamanhos de grão médios e seus respectivos desvios padrões, para as diferentes condições de soldagem, no centro do cordão, nas regiões de avanço, retrocesso e no centro do cordão, sem tratamento térmico posterior. 


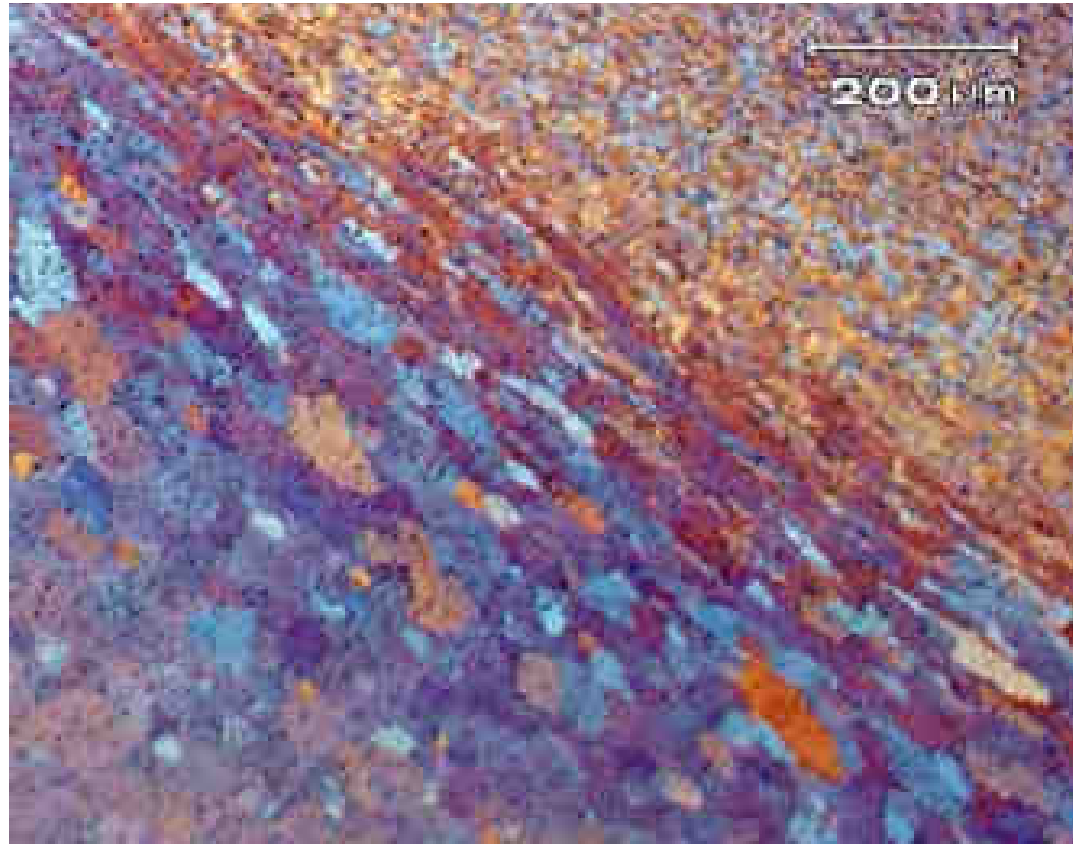

Figura 39 - Microestrutura da zona termomecanicamente afetada do cordão da condição de um passe, lado do avanço, vista frontal.

Analisando-se a tabela 10 nota-se que o tamanho de grão na condição como soldado tende a ser mais refinado na região central do cordão. Nas regiões termomecanicamente afetadas existem grãos alongados e grãos equiaxiais. A região axial tem um tamanho de grão similar a região central.

Tabela 10 - Medidas dos tamanhos de grão $(\mu \mathrm{m})$. Vista frontal. Condição como-soldado.

\begin{tabular}{|c|c|c|c|c|}
\hline Metal de base & 34 & & & \\
\hline & & \multicolumn{3}{|c|}{ Condição de soldagem } \\
\hline Região & & 1 Passe & $\begin{array}{l}2 \text { Passes sem } \\
\text { Inversão }\end{array}$ & $\begin{array}{l}2 \text { Passes com } \\
\text { Inversão }\end{array}$ \\
\hline \multirow{2}{*}{ Avanço } & Grãos Alongados & $16,9 \pm 3,9$ & $18,6 \pm 2,2$ & $18,0 \pm 1,8$ \\
\hline & Grãos Equiaxias & $7,3 \pm 0,5$ & $8,6 \pm 1,7$ & $7,5 \pm 0,8$ \\
\hline Centro & & $7,6 \pm 0,4$ & $8,1 \pm 1,7$ & $7,7 \pm 0,4$ \\
\hline \multirow{2}{*}{ Retrocesso } & Grãos Alongados & $23,9 \pm 5,3$ & $12,7 \pm 1,0$ & $10,0 \pm 0,8$ \\
\hline & Grãos Equiaxiais & $7,3 \pm 1,5$ & $8,2 \pm 0,4$ & $7,0 \pm 1,1$ \\
\hline
\end{tabular}


Para avaliar a influência das condições de soldagem nos tamanhos dos grãos alongados na região de avanço e retrocesso foi utilizada a técnica de delineamento de experimento, descrita no item materiais e métodos, para analisar os efeitos das condições de soldagem e da localização das medidas, cujos resultados estão apresentados na figura 40, para a região do cordão com grãos alongados, que não foram observados no centro do cordão.

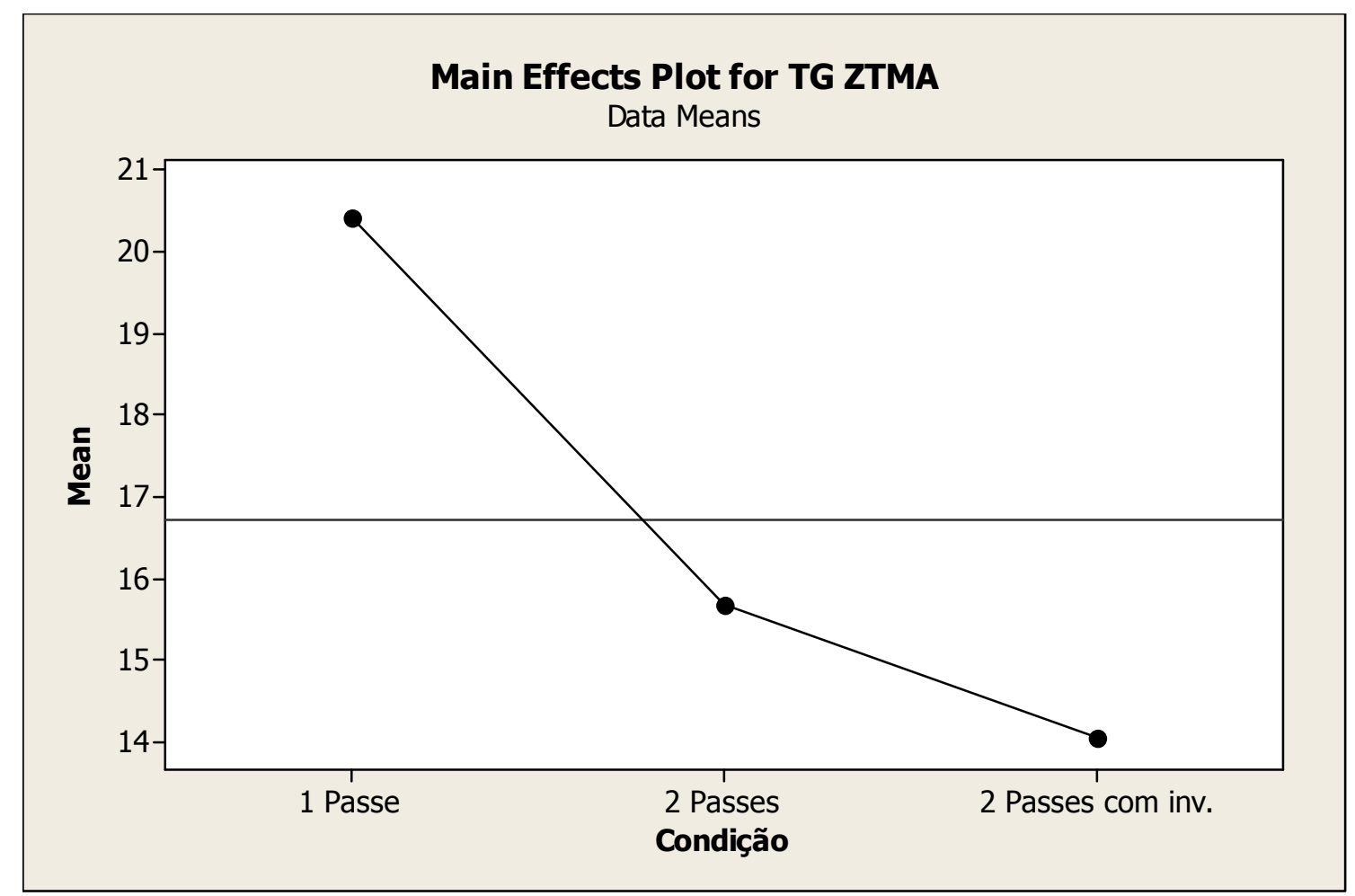

Figura 40 - Gráfico dos efeitos das condições de soldagem no tamanho de grão médio na região de grãos alongados.

Os resultados mostraram que somente o tipo de condição de soldagem e a interação entre a condição de soldagem e a região de medida, avanço ou retrocesso, tiveram efeito no tamanho de grão médio. Após o primeiro cordão, com a realização do segundo cordão no mesmo sentido, os grãos ficaram mais alongados, refletindo a queda no tamanho de grão médio mostrado na figura 40. Quando foi realizado o segundo cordão com inversão de sentido, o lado que era avanço passa a ser retrocesso, e vice-versa, modificando o 
fluxo de material, como apresentado anteriormente. Desta maneira, fica explicada a redução do tamanho de grão médio quando se tem o segundo cordão sem e com inversão de sentido. Este comportamento pode estar relacionado com o tipo de solicitação mecânica que se tem no lado do avanço e no lado do retrocesso ${ }^{(81)}$.

A figura 41 apresenta a interação entre os fatores de condição de soldagem e a localização no cordão de forma separada. Os resultados mostram que o tamanho de grão no avanço para as três condições de soldagem se altera com a localização. No caso da soldagem com um passe ocorre um aumento do tamanho de grão médio quando se passa do lado do avanço para o lado do retrocesso. Por outro lado, quando se observa os tamanhos de grão nos cordões com dois passes, ocorre uma diminuição do tamanho de grão médio quando se passa do lado do avanço para o lado do retrocesso.

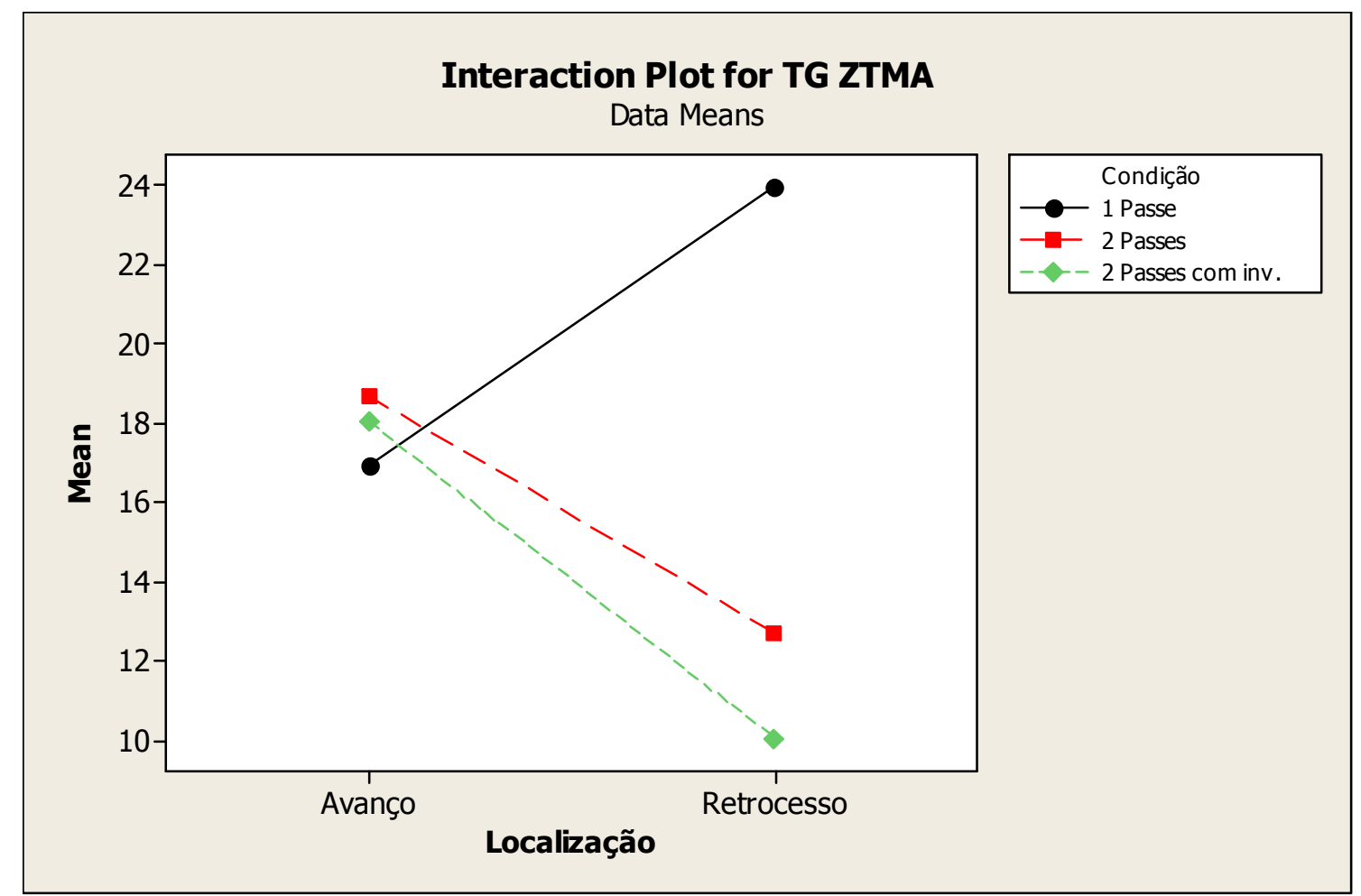

Figura 41 - Efeito das interações no tamanho de grão como-soldado.

Para que este fenômeno de redução de tamanho dos grãos alongados ocorra é preciso que os serrilhados dos grãos alongados se aproximem do parâmetro de Zenner- 
Holloman. Quando esta condição acontece o grão alongado se subdivide. A este fenômeno chama-se recuperação dinâmica ${ }^{(57)}$.

A tabela 11 apresenta os cálculos de ANOVA para os efeitos principais na condição como soldada, para os grãos alongados, confirmando os efeitos discutidos anteriormente.

Tabela 11 - ANOVA para os efeitos condição de soldagem, localização e sua interação para os grãos alongados.

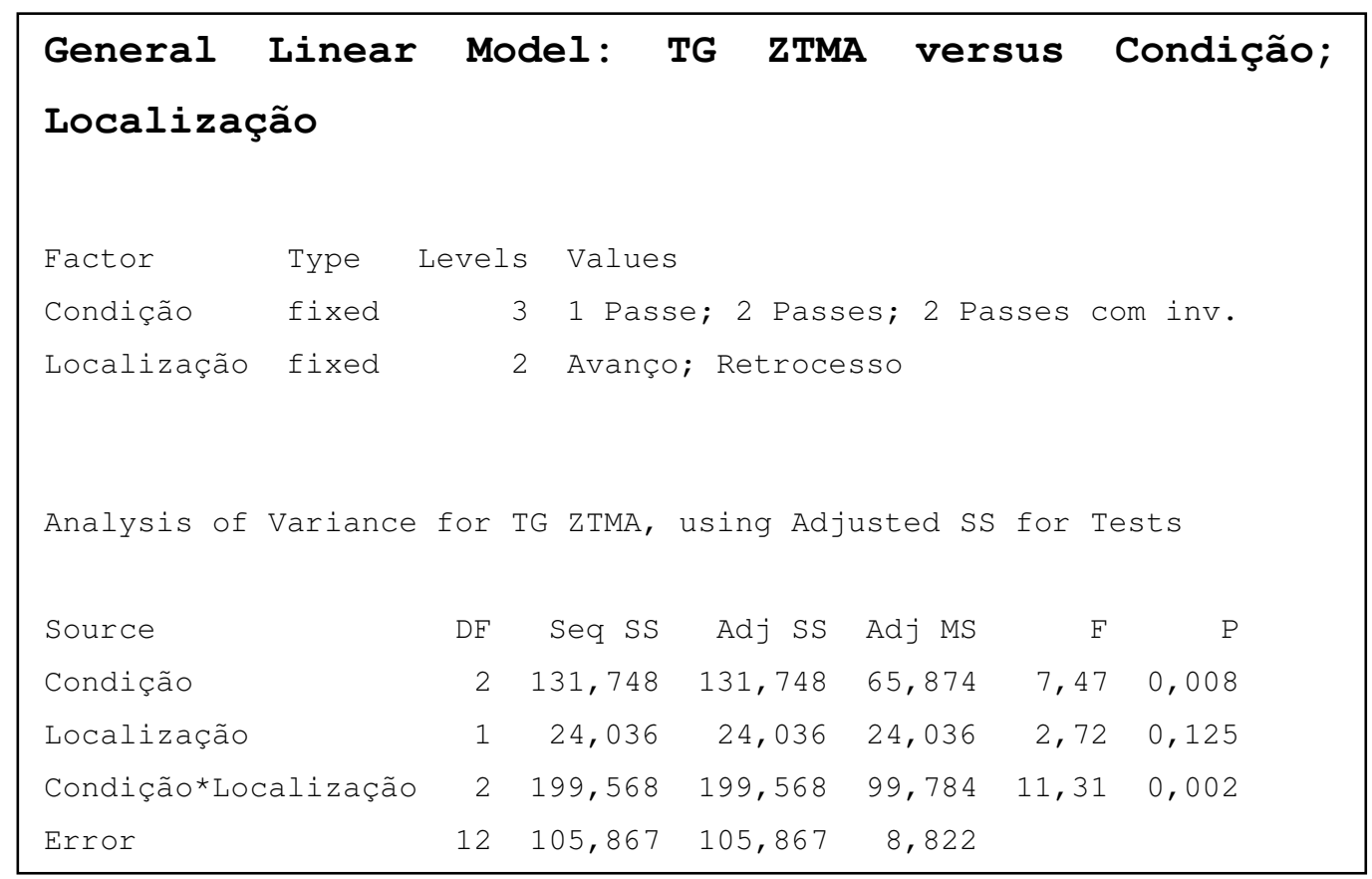

A tabela de análise de variância mostra que tanto o efeito das condições de soldagem como a interação entre as condições de soldagem e a localização são significativos com significância menor que 1\%. Já o efeito da localização é significativo para valores considerados altos, isto é, $12,5 \%$ de significância.

Para a região do cordão que apresenta grãos equiaxiais, como apresentado na figura 42, foram feitos os mesmos testes estatísticos. 


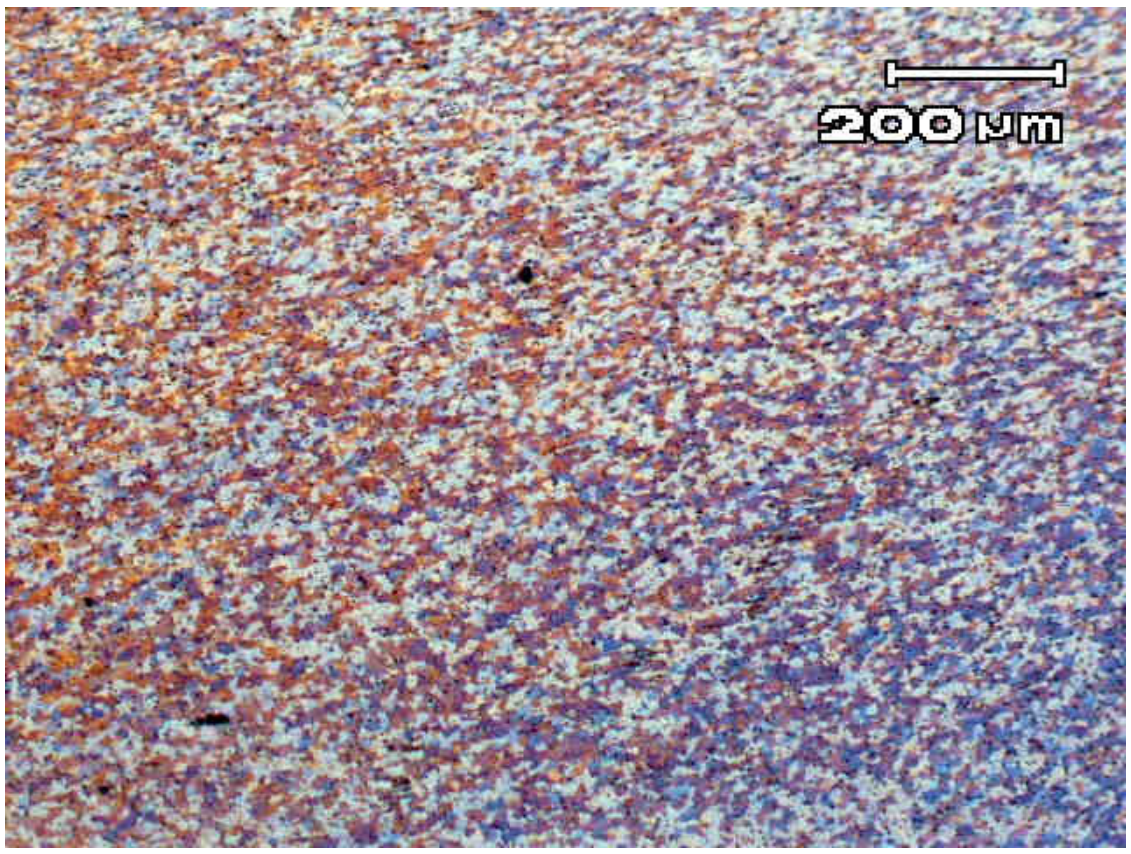

Figura 42 - Microestrutura do centro do cordão mostrando os grãos equiaxiais..

Para os grãos equiaxiais os efeitos das condições de soldagem no tamanho de grão estão apresentados na figura 43.

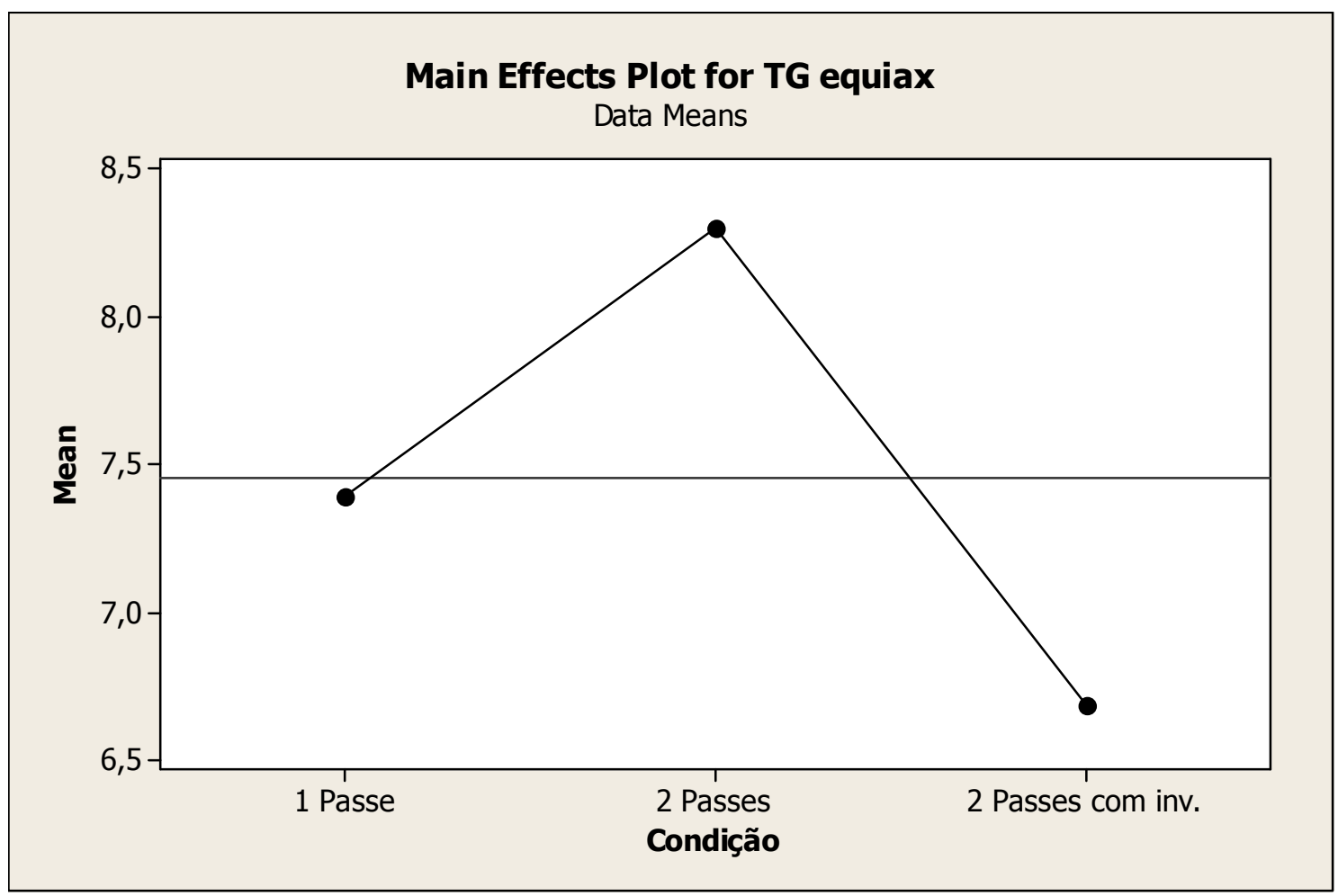

Figura 43 - Efeito da condição de soldagem no tamanho de grão equiaxial. 
Para verificar o efeito das condições de soldagem, localização e interação entre ambos foi feita uma análise de variância para os cordões equiaxiais. A tabela 12 apresenta os cálculos de ANOVA para os efeitos principais na condição como-soldado.

Tabela 12 - ANOVA para os efeitos condição de soldagem, localização e sua interação para os grãos equiaxiais.

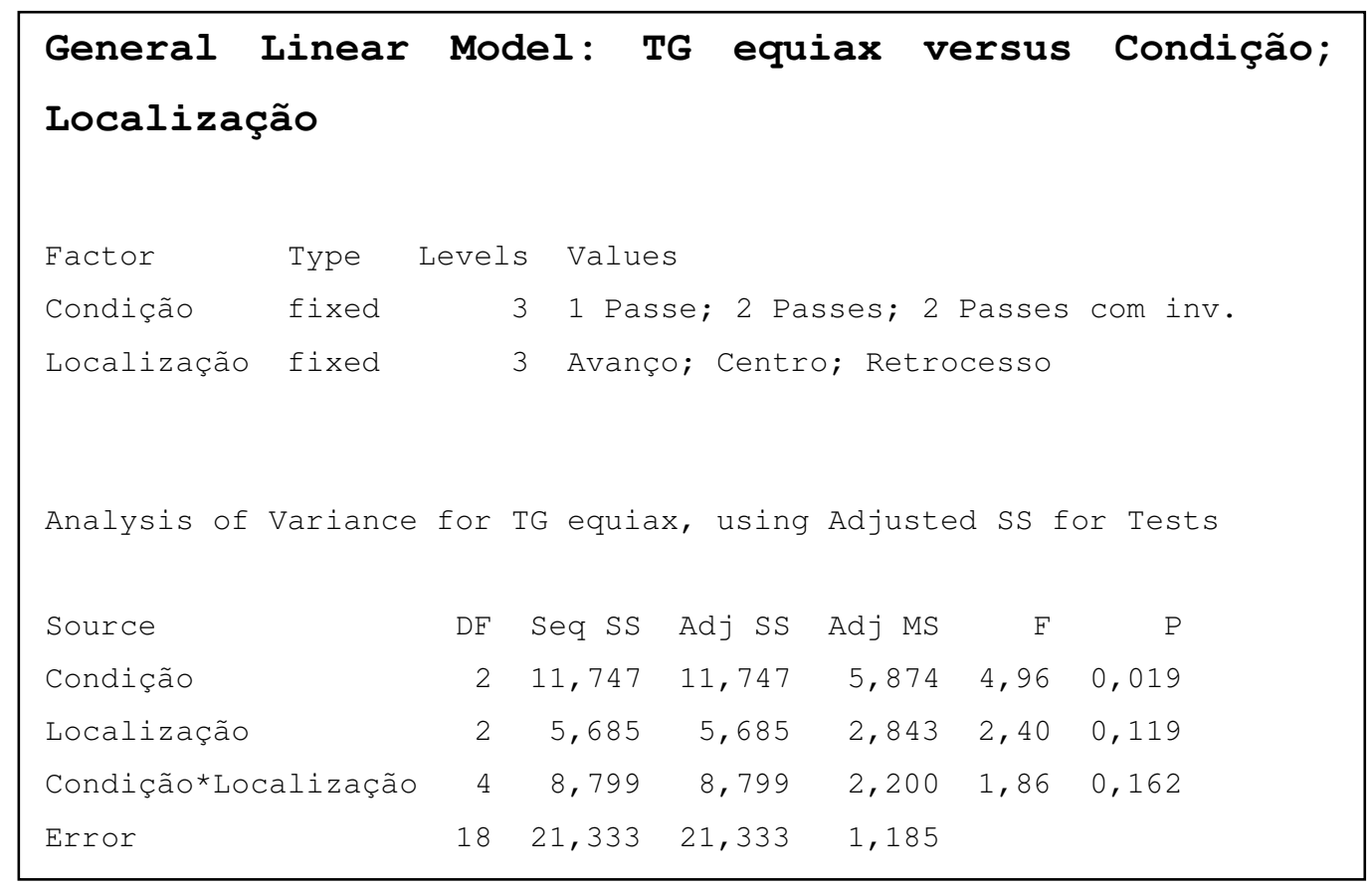

Somente o efeito das condições de soldagem foi significativo para o tamanho de grão dos grãos equiaxiais do cordão de solda, com um índice de significância de $1,9 \%$. O outro efeito e a interação não tiveram resultados significativos para o valor de significância acima da desejada.

A condição de dois passes sem inversão apresentou o maior tamanho de grão equiaxial. O segundo passe no mesmo sentido irá repetir as direções e os sentidos de deformação ocorridos no primeiro passe, porém com uma microestrutura fina e já recristalizada. Este passe elimina heterogeneidades na deformação e solubiliza os precipitados, ocorrendo um maior crescimento de grãos recristalizados do que de nucleação de novos grãos recristalizados. Já a soldagem com inversão de sentido no segundo passe os grãos são 
menores. Provavelmente ocorreu uma maior nucleação facilitada pela difusão devido a maior presença de contornos de grão, gerando recristalização dinâmica menos acentuada do que na condição de dois passes com inversão. Com o aquecimento durante a deformação, ocorre a solubilização dos precipitados e na condição de dois passes sem inversão o grão cresce.

$\mathrm{Na}$ condição de dois passes com inversão ocorrem alterações nas direções e sentidos de fluxo de material. As heterogeneidades de deformação são acentuadas e as deformações são mais expressivas, levando à recristalização dinâmica do material, como na condição do primeiro passe.

\subsubsection{Condição tratada após soldagem}

\subsubsection{Microestrutura}

A figura 44 mostra o tamanho de grão do metal base na condição como-recebido. As microestruturas obtidas após os tratamentos térmicos são apresentadas nas figuras 45 a 54. São mostrados os cordões nas vistas frontal, superior e de raiz das três condições de soldagem, isto é, com cordões produzidos por um passe e dois passes com a mesma direção de rotação do pino, e dois passes com a rotação do pino invertida no segundo passe.

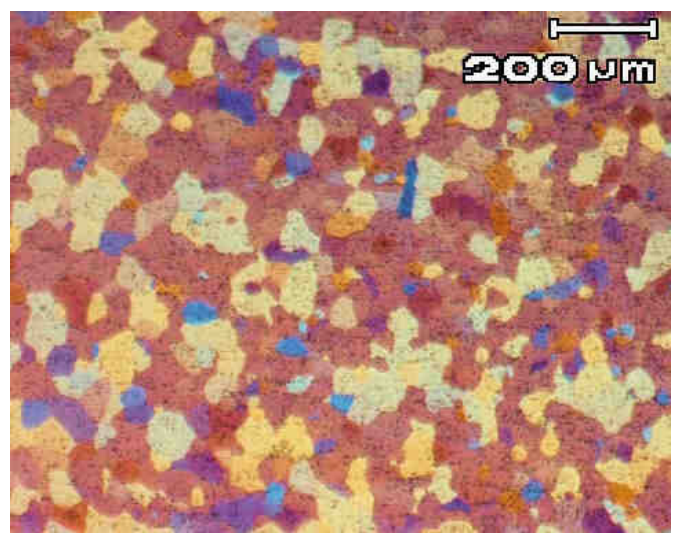

Figura 44 - Microestrutura do metal de base na condição como-recebido.. Ataque: Barker 1,8\%. 
A Figura 44 está ao lado das figuras seguintes, na mesma escala como referência. Na Figura 45 o tratamento térmico de solubilização a $863 \mathrm{~K}\left(59{ }^{\circ} \mathrm{O}\right)$ por 2 horas produziu grãos maiores quando comparados com o metal de base original. Os grãos no cordão têm característica predominante equiaxial. Na região termomecanicamente afetada apresentam um formato alongado.

A figura 46 mostra que o tamanho de grão ficou maior nos corpos de prova solubilizados e envelhecidos quando comparados com o corpo de prova somente solubilizado. Na ZTMA os tamanhos de grão ficaram bem próximos para os dois tratamentos.

As microestruturas provenientes do recozimento a $623 \mathrm{~K}\left(350^{\circ} \mathrm{C}\right)$, figuras 47 e 48 , são muito parecidas com as microestruturas dos corpos de prova na condição como soldados. A diferença é que os corpos de prova tratados apresentam áreas deformadas pelo ombro da ferramenta, na parte superior do cordão, onde é visível a recristalização secundária dos grãos. Este efeito é mais marcado para tempos mais prolongados e para a condição com dois passes, apresentando uma área maior para o cordão com reversão de sentido da ferramenta. A evolução desta área com recristalização secundária também é visível na vista superior do cordão recozido, onde é possível ver os grãos crescendo sobre as bandas de deformação, conforme mostra a figura 51. Já os cordões solubilizados e os envelhecidos, figuras 49 e 50, também apresentaram um aumento no tamanho de grão, principalmente para a condição de dois passes com reversão do sentido da ferramenta.

A vista de raiz na condição recozida apresenta uma microestrutura muito similar a da condição como soldada, figura 54. Devido ao fluxo de material, apresentado na figura 18, a condição com dois passes e reversão da ferramenta apresentou um tamanho de grão maior. Já os corpos de prova solubilizados e envelhecidos, figuras 52 e 53, apresentam um crescimento de grão acentuado, principalmente na condição com dois passes e reversão da ferramenta. 
(a)

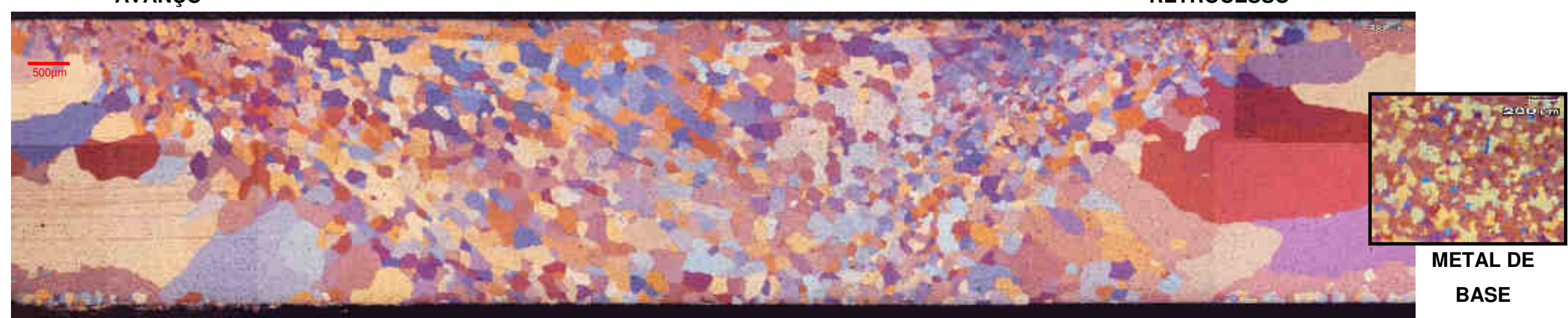

(b)

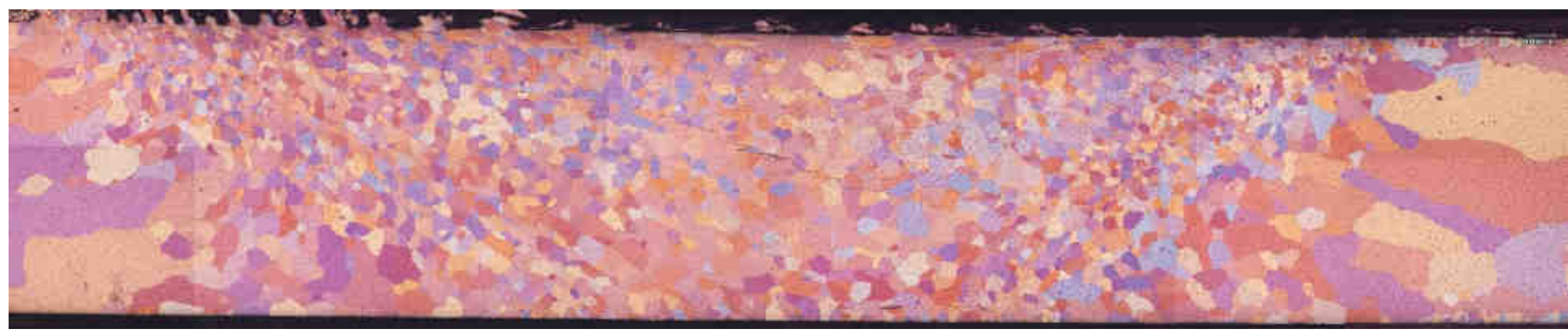

(c)

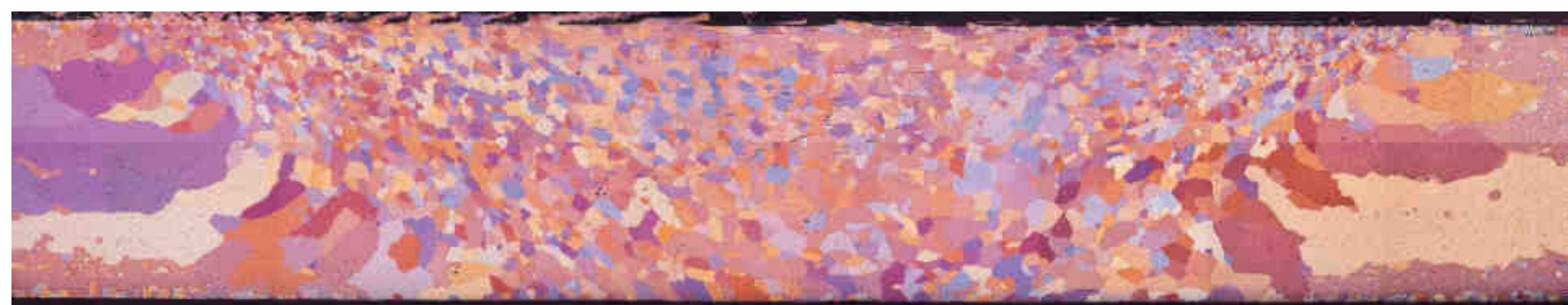

Figura 45 - Microestruturas frontais das seções dos cordões. (a) 1 passe Solubilizado (b) 2 passes sem inversão Solubilizado (c) 2 passes com inversão Solubilizado. Ataque: Barker 1,8\%. 
(a)

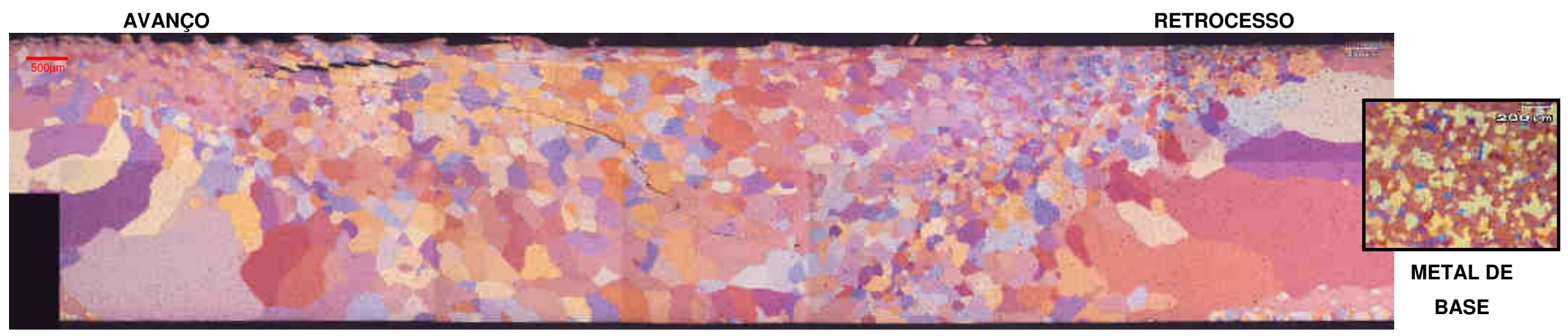

(b)

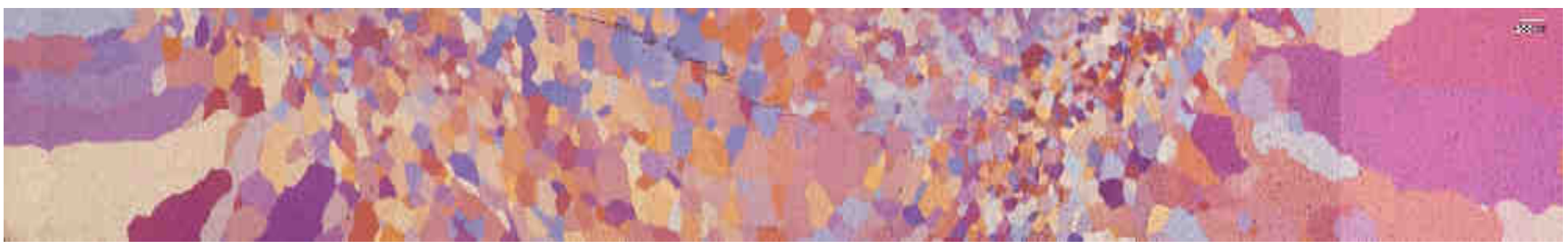

(c)

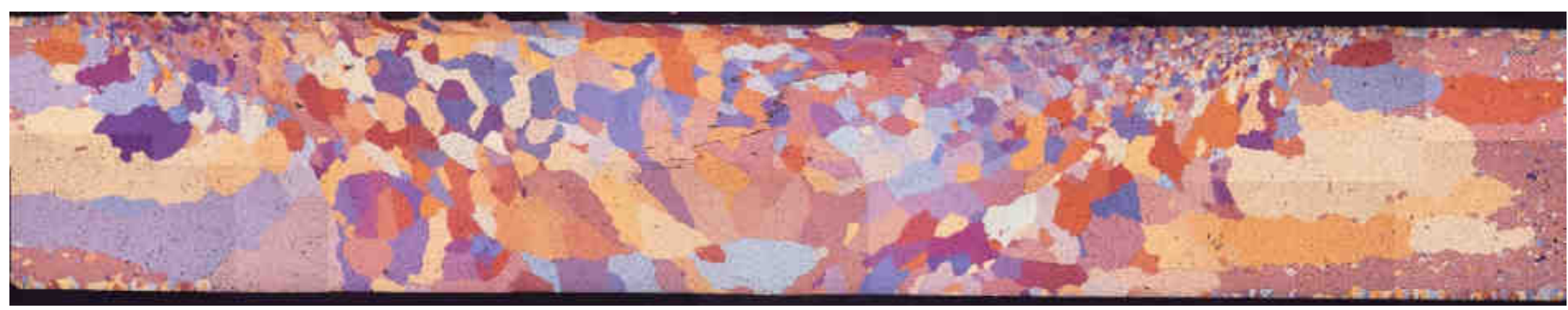

Figura 46 - Microestruturas frontais das seções dos cordões. (a) 1 passe Envelhecido (b) 2 passes sem inversão Envelhecido (c) 2 passes com inversão Envelhecido. Ataque: Barker 1,8\%. 
AVANÇO

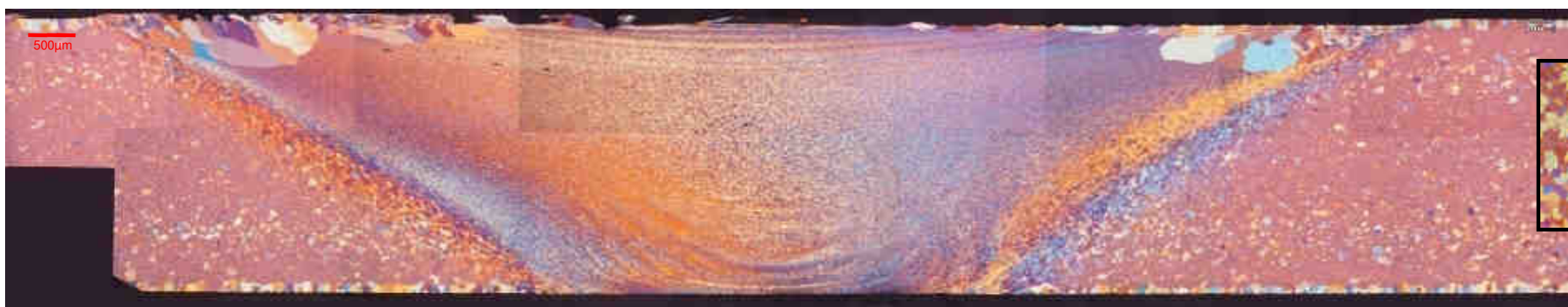

(a)

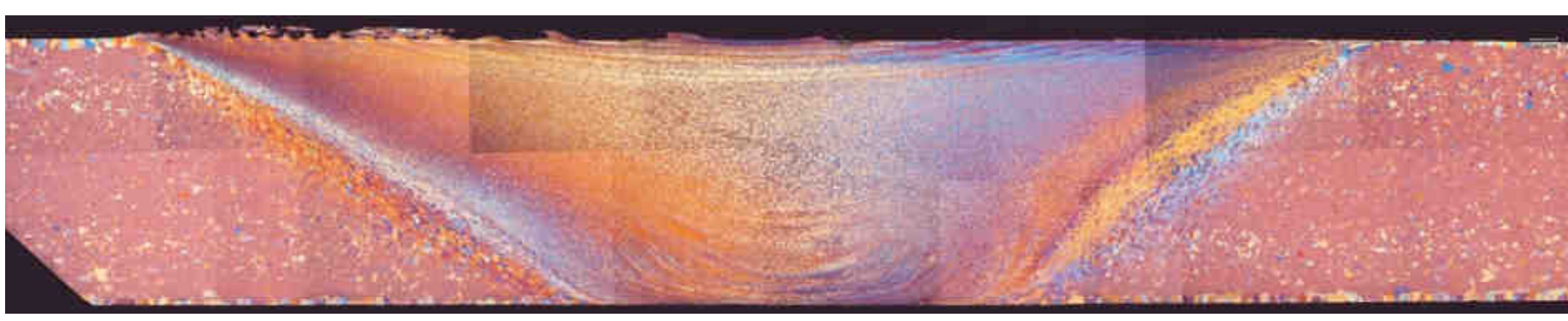

(b)

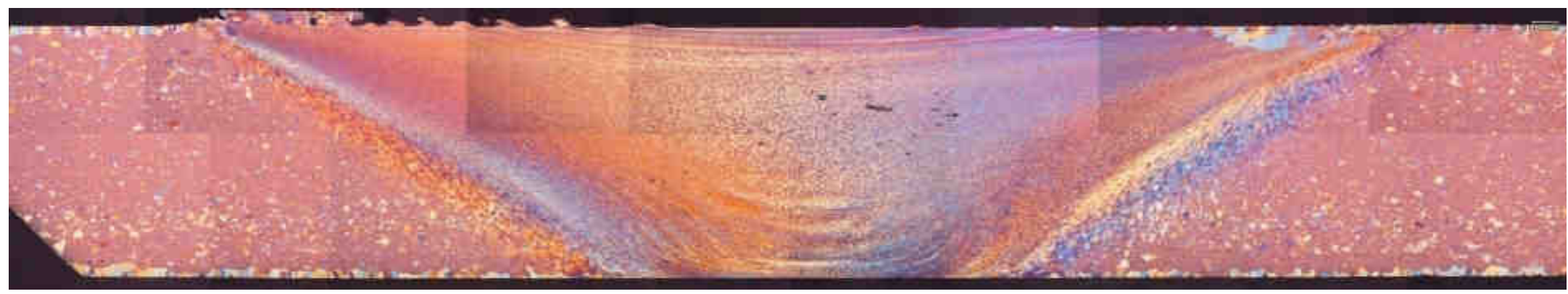

Figura 47 - Microestruturas frontais das seções dos cordões. (a) 1 passe Recozido, $2 \mathrm{~h}$ (b) 2 passes sem inversão Recozido $2 \mathrm{~h}$ (c) 2 passes com inversão Recozido 2h. Ataque: Barker 1,8\%. 
AVANCSO

RETROCESSO
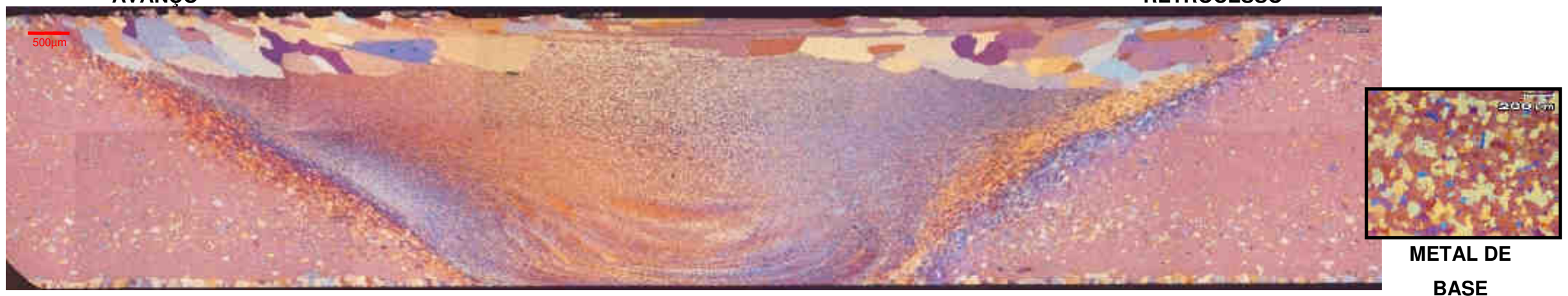

METAL DE

BASE

(b)

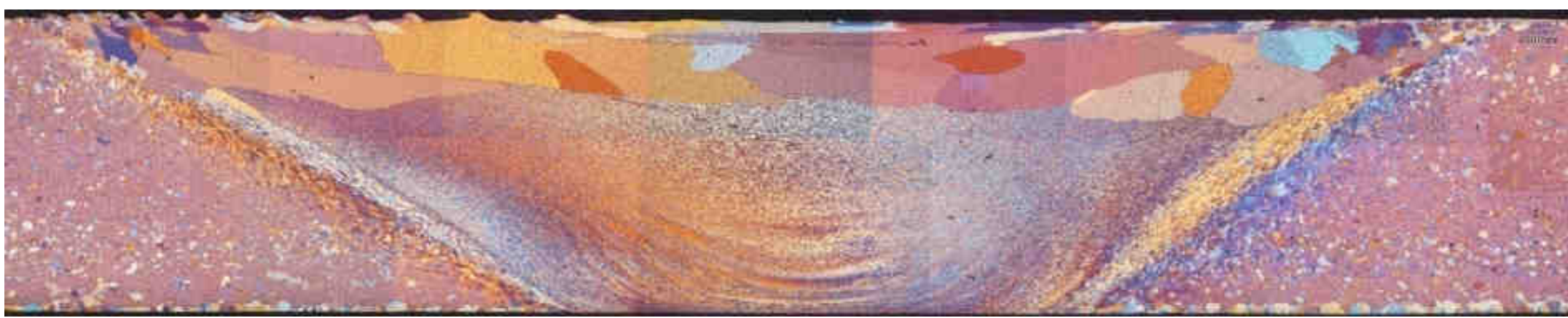

(c)

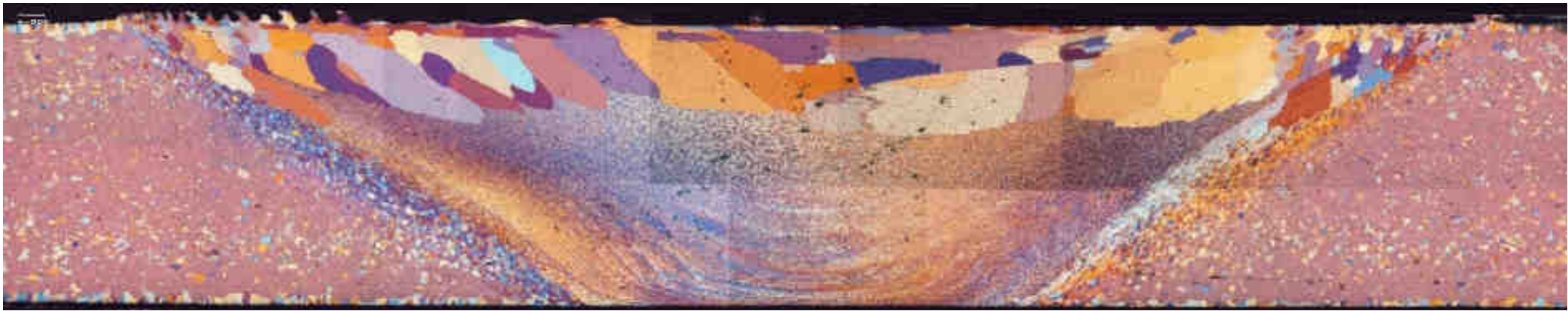

Figura 48 - Microestruturas frontais das seções dos cordões. (a) 1 passe Recozido, 8h (b) 2 passes sem inversão Recozido 8h (c) 2 passes com inversão Recozido 8h. Ataque: Barker 1,8\%. 
(a)

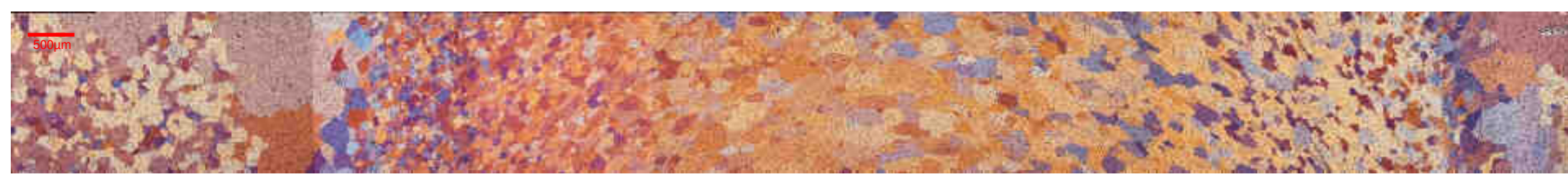

(b)

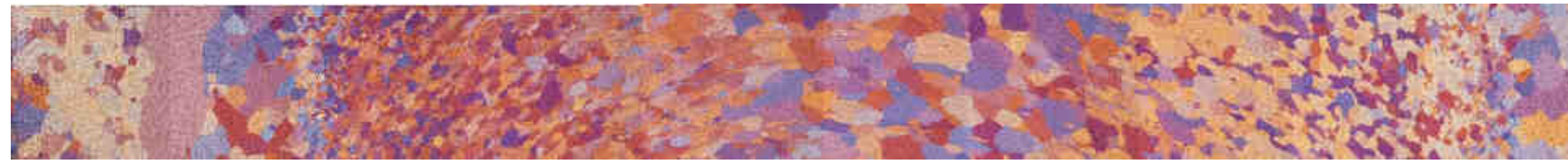

(c)

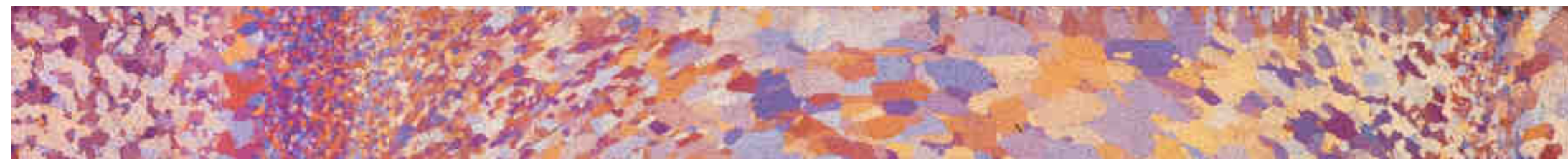

Figura 49 - Microestruturas da vista superior dos cordões. (a) 1 passe Solubilizado (b) 2 passes sem inversão Solubilizado (c) 2 passes com inversão Solubilizado. Ataque: Barker 1,8\%. 
(a)

RETROCESSO

AVANÇO

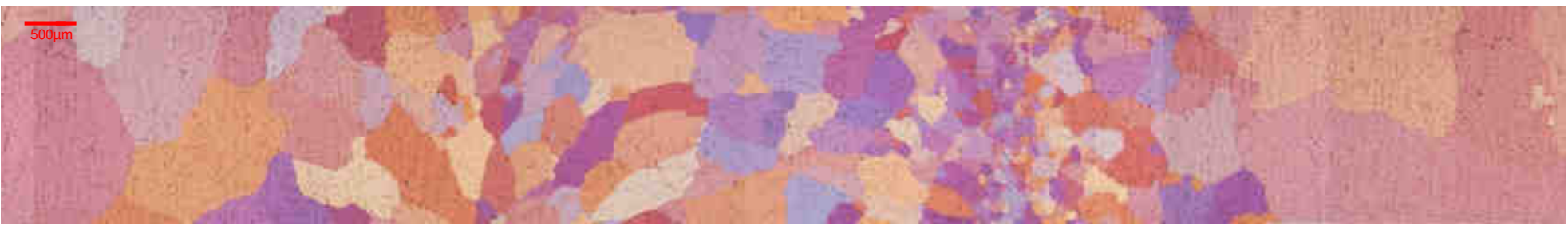

(b)

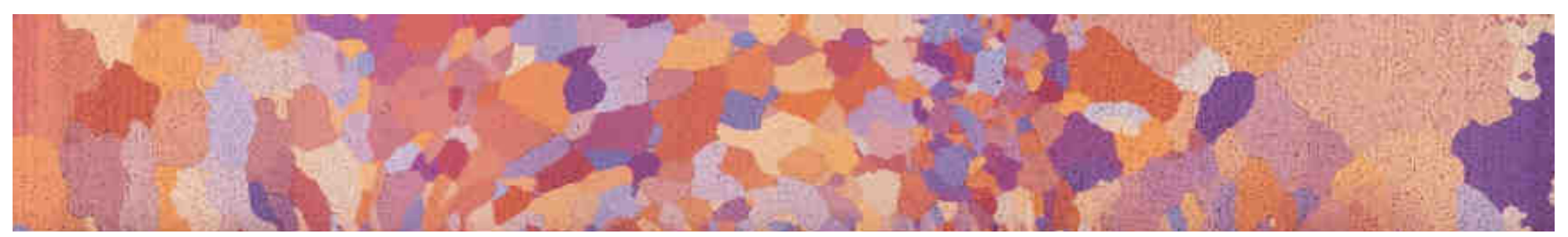

(C)

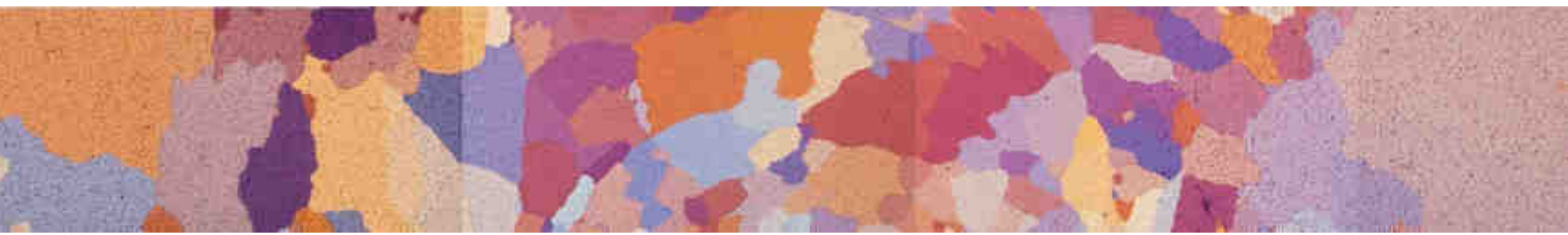

Figura 50 - Microestruturas da vista superior dos cordões. (a) 1 passe Envelhecido (b) 2 passes sem inversão Envelhecido (c) 2 passes com inversão Envelhecido. Ataque: Barker 1,8\%. 
RETROCESSO

(a)

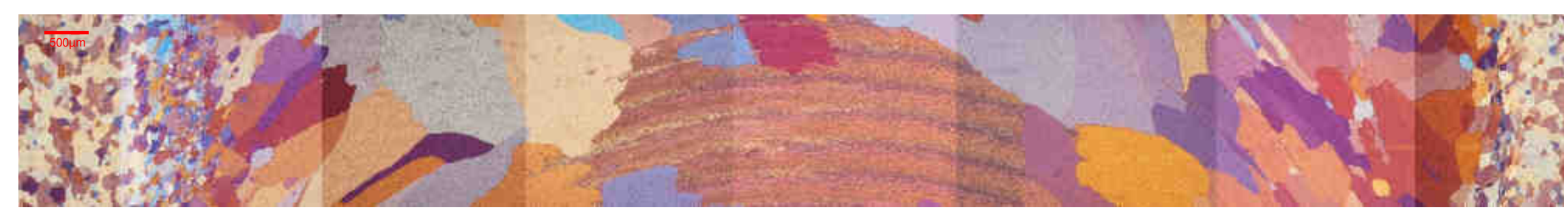

(b)

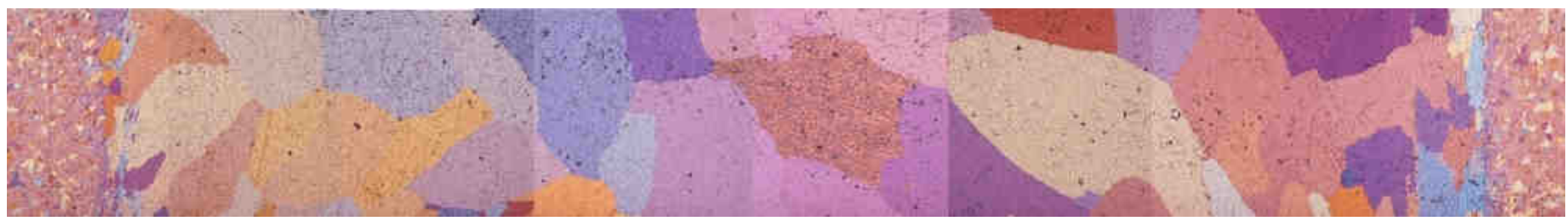

(c)

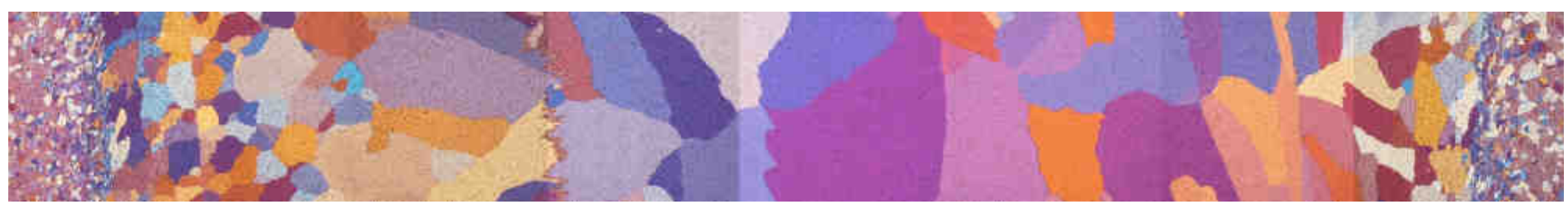

Figura 51 - Microestruturas da vista superior dos cordões. (a) 1 passe Recozido 8h (b) 2 passes sem inversão Recozido 8h (c) 2 passes com inversão Recozido 8h. Ataque: Barker 1,8\%. 


\section{RETROCESSO}

AVANÇO

(a)

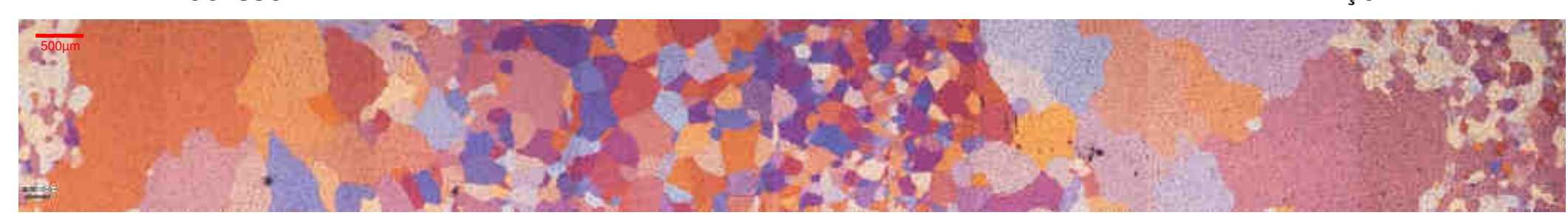

(b)

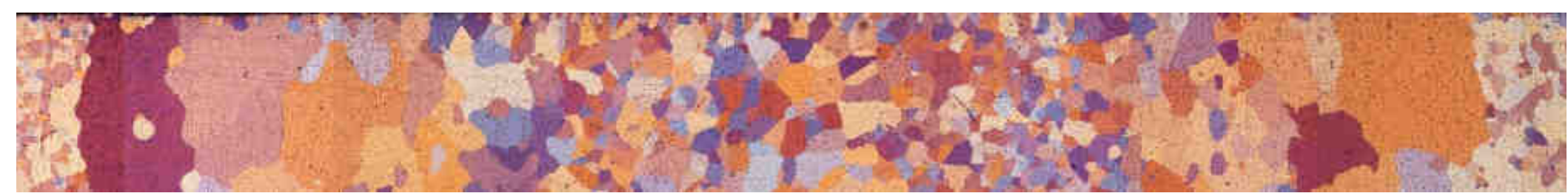

(c)

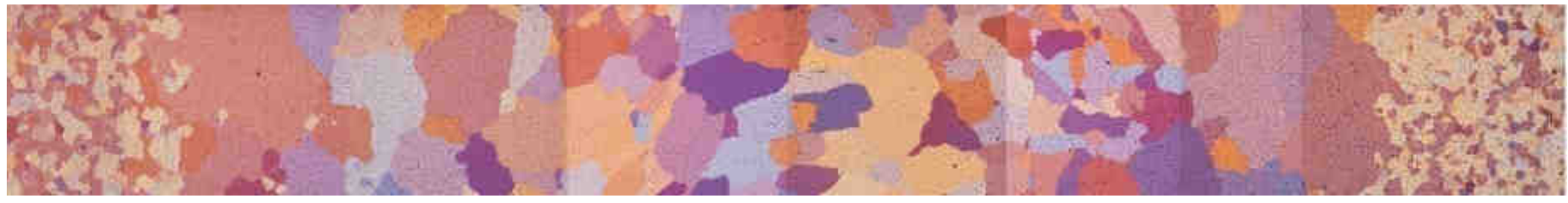

Figura 52 - Microestruturas da vista da raiz dos cordões. (a) 1 passe Solubilizado (b) 2 passes sem inversão Solubilizado (c) 2 passes com inversão Solubilizado. Ataque: Barker 1,8\%. 
(a)

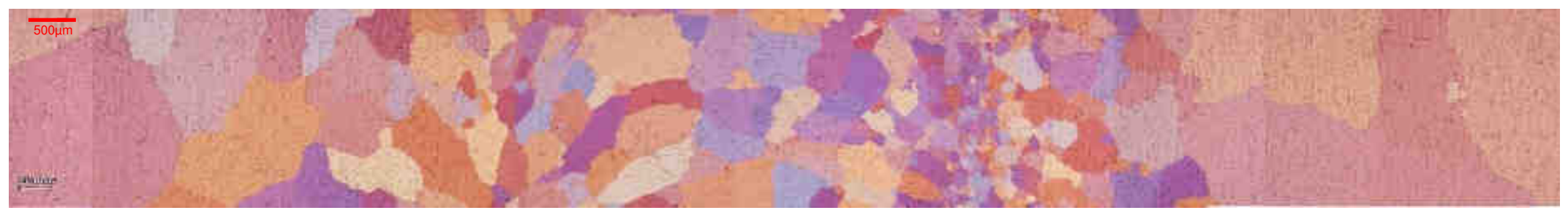

(b)

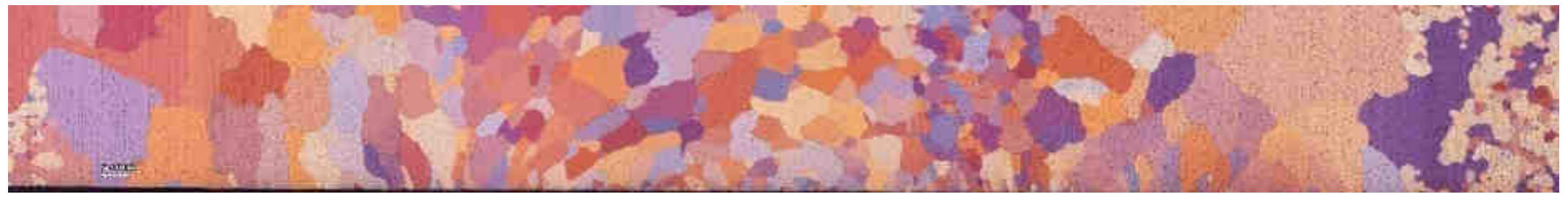

(c)

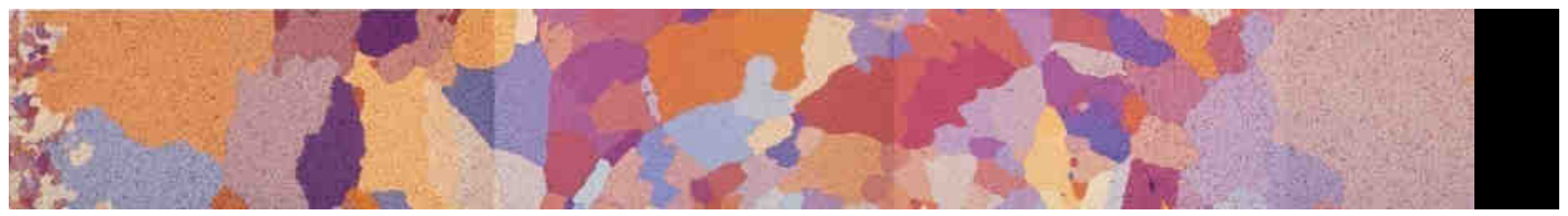

Figura 53 - Microestruturas da vista da raiz dos cordões. (a) 1 passe Envelhecido (b) 2 passes sem inversão Envelhecido (c) 2 passes com inversão Envelhecido. Ataque: Barker 1,8\%. 
(a)

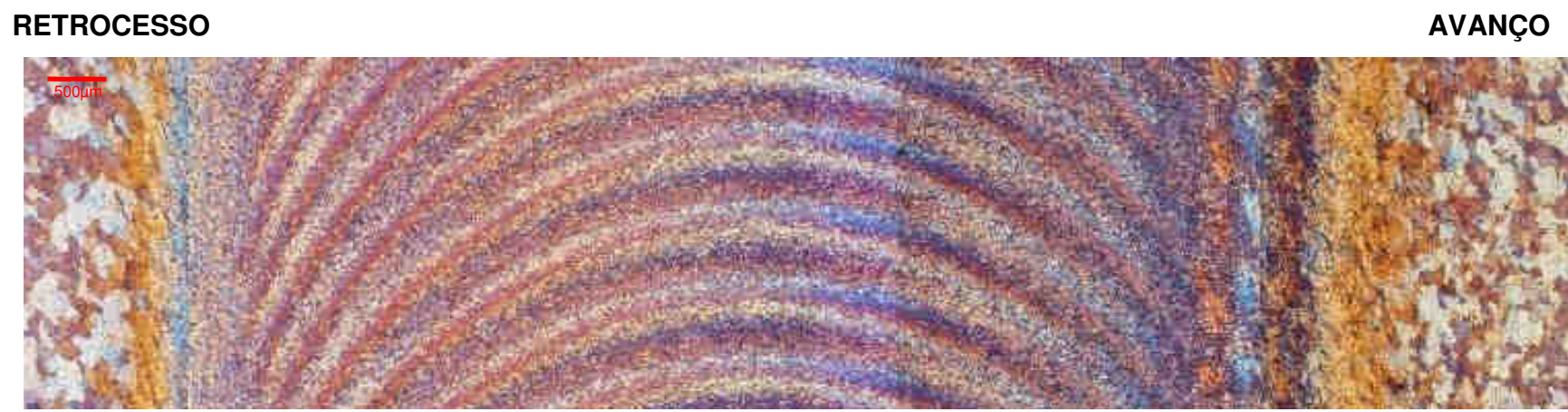

(b)

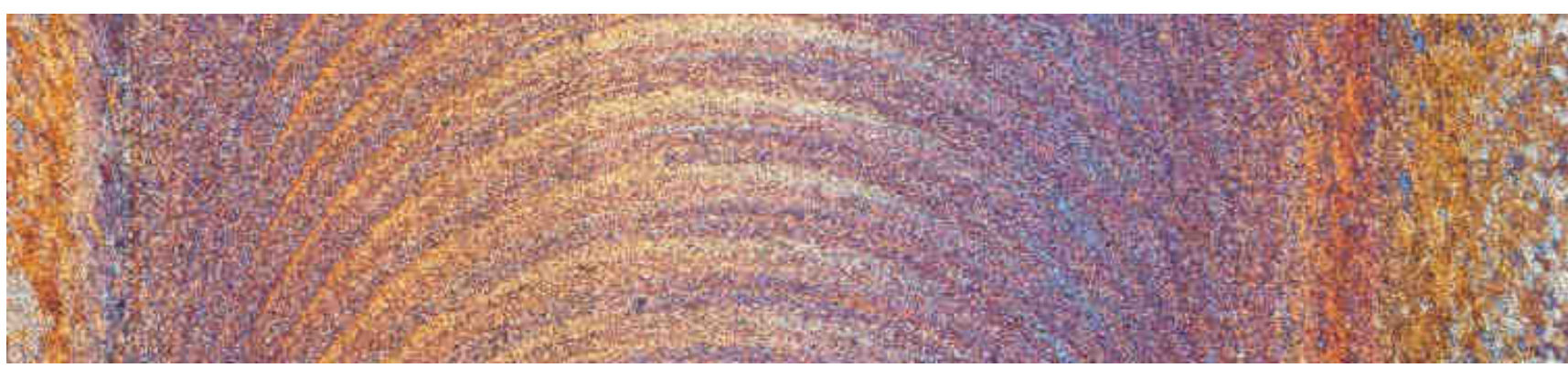

(c)

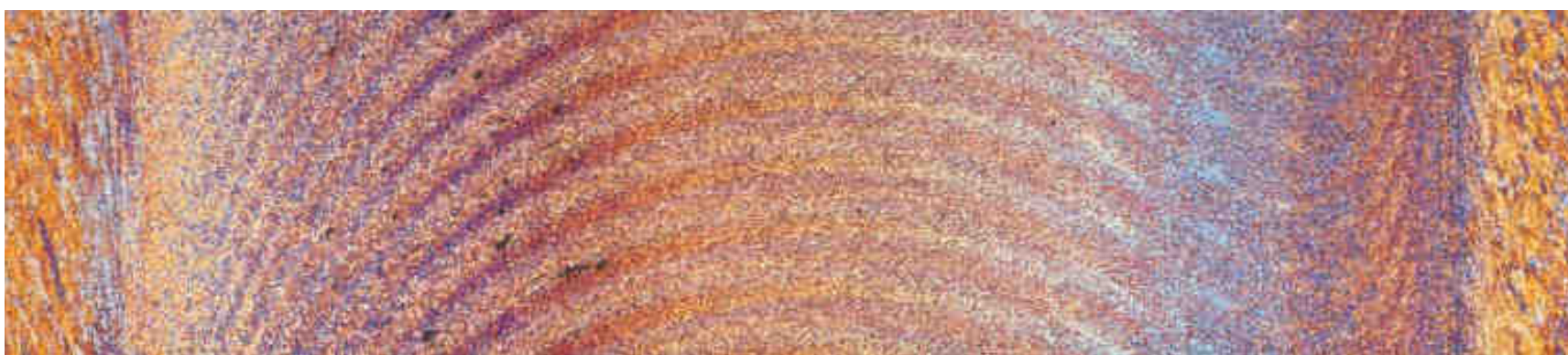

Figura 54 - Microestruturas da vista da raiz dos cordões. (a) 1 passe Recozido $8 \mathrm{~h}$ (b) 2 passes sem inversão Recozido $8 \mathrm{~h}$ (c) 2 passes com inversão Recozido 8h. Ataque: Barker 1,8\%. 


\subsubsection{Medidas de Tamanho de Grão}

\subsubsection{1 Área recristalizada com o tratamento térmico pós-soldagem.}

Foram calculadas as constantes b e c para a equação (7) de Johnson-Mehl-AvramiKolmogorov ${ }^{(61)}$. A evolução das áreas de recristalização secundária obtida nos cordões recozidos, junto com os respectivos parâmetros calculados é apresentada na tabela 13.

Tabela 13 - Medidas de frações recristalizadas secundariamente dos cordões soldados.

\begin{tabular}{|c|c|c|c|c|c|c|c|c|}
\hline \multirow{3}{*}{$\begin{array}{l}\text { Condição do } \\
\text { Cordão }\end{array}$} & \multicolumn{6}{|c|}{ Tempo de Recozimento } & \multicolumn{2}{|c|}{ Constantes } \\
\hline & \multicolumn{3}{|c|}{2 horas } & \multicolumn{3}{|c|}{8 horas } & & \\
\hline & $\begin{array}{c}\text { Avanço } \\
\left(\mathrm{mm}^{2}\right)\end{array}$ & $\begin{array}{c}\text { Retrocesso } \\
\left(\mathrm{mm}^{2}\right)\end{array}$ & $\begin{array}{l}\text { Total } \\
\left(\mathrm{mm}^{2}\right) \\
\end{array}$ & $\begin{array}{c}\text { Avanço } \\
\left(\mathrm{mm}^{2}\right)\end{array}$ & $\begin{array}{c}\text { Retrocesso } \\
\left(\mathrm{mm}^{2}\right)\end{array}$ & $\begin{array}{l}\text { Total } \\
\left(\mathrm{mm}^{2}\right) \\
\end{array}$ & $b$ & C \\
\hline 1 Passe & 0,0317 & 0,0220 & 0,0537 & 0,0660 & 0,0678 & 0,1337 & 0,000121 & 0,6893 \\
\hline $\begin{array}{l}2 \text { Passes sem } \\
\text { inversão }\end{array}$ & 0,0002 & 0,0009 & 0,0011 & 0,0996 & 0,0951 & 0,1946 & $4,80 \mathrm{E}-09$ & 1,7130 \\
\hline $\begin{array}{l}2 \text { Passes com } \\
\text { inversão }\end{array}$ & 0,0065 & 0,0120 & 0,0184 & 0,1165 & 0,1261 & 0,2426 & 8,01E-09 & 1,6900 \\
\hline
\end{tabular}

As retas calculadas pela equação (7) para o crescimento da fração recristalizada secundariamente estão apresentadas na figura 55.

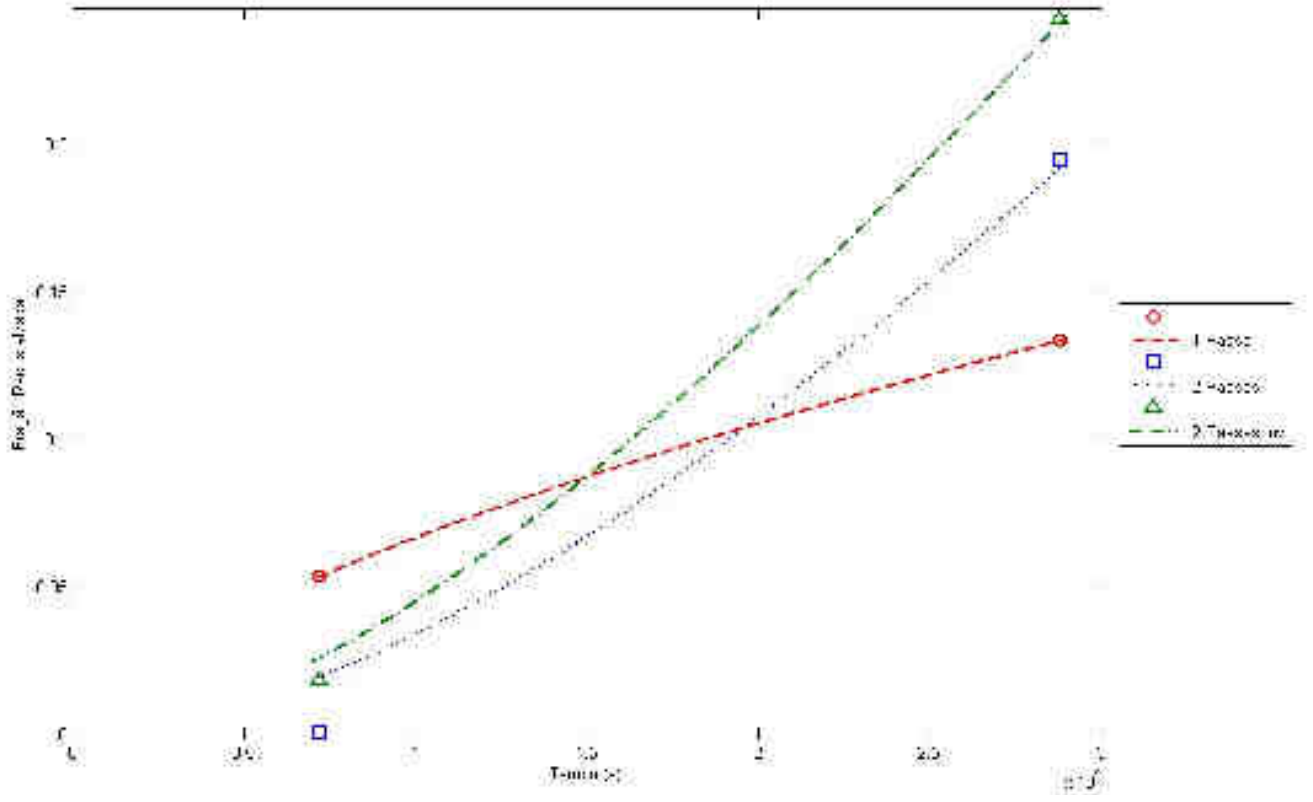

Figura 55 - Gráfico de fração recristalizada ao longo do tempo para o recozimento. Curvas para fração recristalizada total. Os símbolos indicam os valores medidos. 
A condição de um passe apresenta uma fração recristalizada secundariamente inicialmente maior, para um tempo de recozimento de $2 \mathrm{~h}$. Porém, com o aumento do tempo de recozimento esta fração recristalizada secundariamente passa a ser superior nas condições de dois passes. A recristalização secundária inicia-se, nas três condições de soldagem, na região superior do cordão avançando para dentro do cordão.

A figura 56 apresenta a frente de recristalização para duas horas de recozimento, para a soldagem com um único passe. O cordão se encontra solubilizado permitindo a migração do contorno de alto ângulo.

A região superior fica em contato com o ombro da ferramenta, sendo uma região com alta taxa de deformação e grande fluxo de material, como mostrado na figura 18, e, assim, apresentando também uma maior propensão a heterogeneidades de deformação, que favorecem a recristalização secundária.

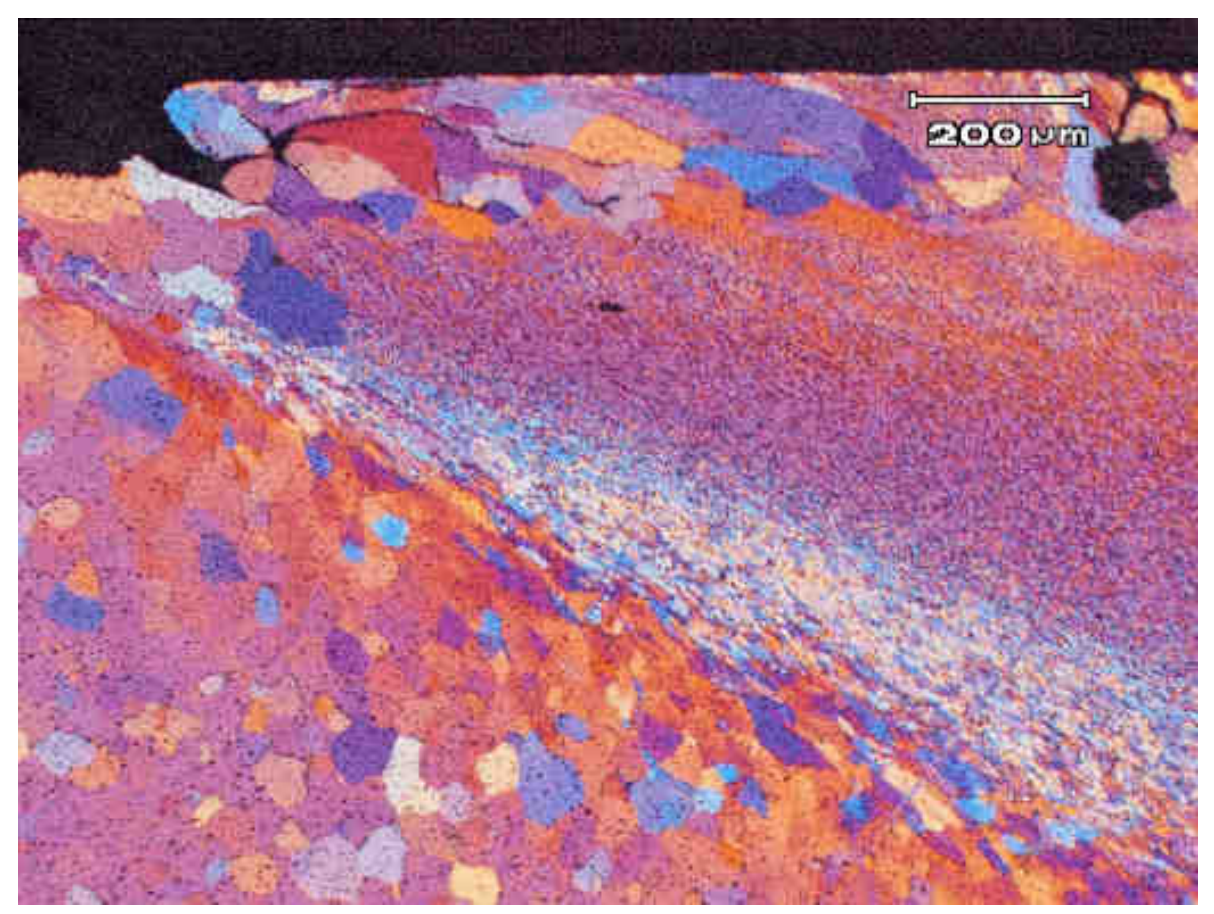

Figura 56 - Recristalização secundária avançando da superfície para o centro do cordão. Soldagem com um único passe, lado do avanço. Ataque: Barker. 
Além da heterogeneidade de deformação, a presença de diferenças de orientação elevadas entre os grãos favorece a recristalização secundária. Esta condição é acentuada pelas deformações elevadas no segundo passe e no segundo passe com inversão.

A temperatura de recozimento escolhida para esta liga de alumínio deve, provavelmente, situar- se na faixa de temperatura onde ocorre a alteração da energia de ativação para recristalização de materiais severamente deformados ${ }^{(64,65,}$ 66) e, nesta faixa, ocorre o crescimento anormal de grão.

O resultado do teste estatístico para verificar a influência das condições de soldagem nas frações recristalizadas secundariamente é apresentado na figura 57. O resultado mostrou que não houve nenhuma diferença significativa na área recristalizada entre o lado de avanço e retrocesso, porém houve uma influência significativa do tempo de recozimento e das condições de soldagem.

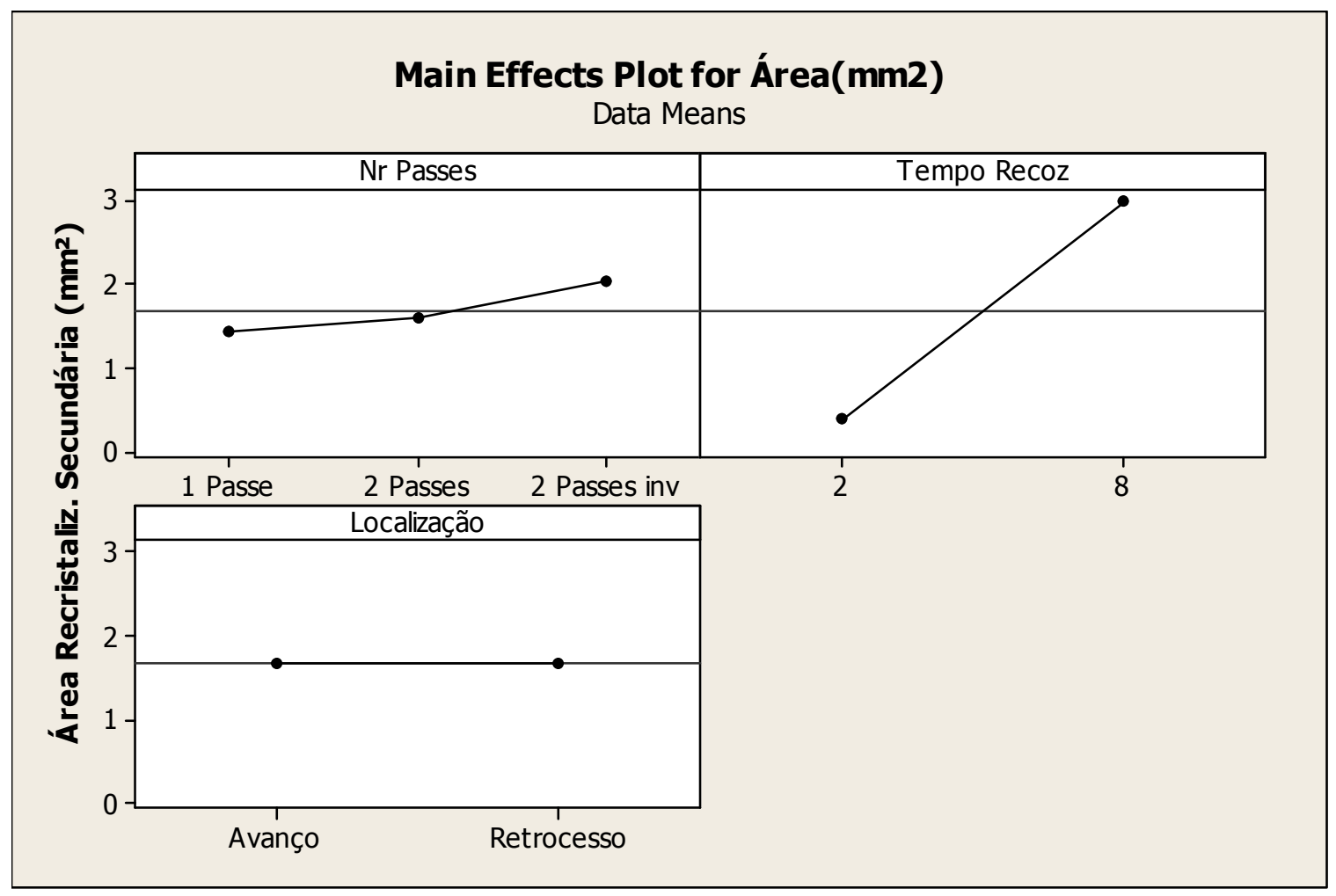

Figura 57 - Efeito das condições de soldagem, tratamento térmico posterior e localização na área de recristalização secundária do cordão. 
Para a análise dos efeitos foi utilizada a técnica de da Análise de Médias (Analysis of Means - ANOM), pois não há replicação. A figura 58 apresenta os cálculos, que é um método gráfico similar a ANOVA, que testa os efeitos principais do experimento $^{(104)}$. Nesta análise com um nível de significância de 1\% estão indicados os fatores significativos na alteração da área recristalizada secundariamente. A análise inclui também o efeito das interações entre os fatores de influência, onde se nota um efeito sinérgico entre dois passes com inversão e tempo de recozimento no efeito da fração recristalizada secundariamente. Esta interação indica que, com o aumento de tempo de recozimento na amostra com dois passes com inversão, o aumento da área recristalizada foi maior do que nas outras condições soldadas.

O cordão de dois passes sem inversão apresenta a mesma tendência de sinergia com o tempo de recozimento, porém para esta interação só pode ser afirmada para um nível de significância de $2 \%$.

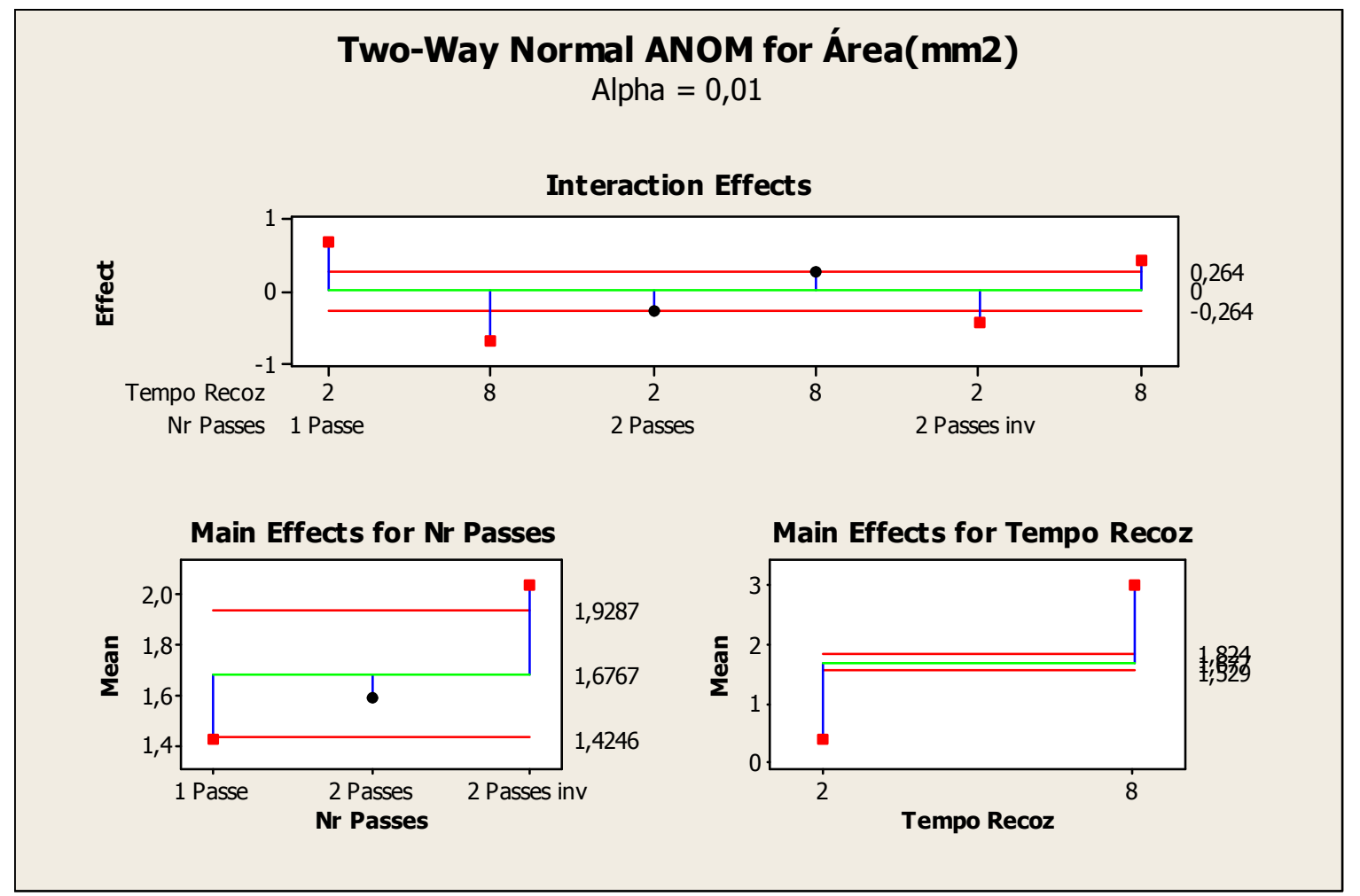

Figura 58 - Análise de ANOM indicando os efeitos significativos na alteração da área recristalizada secundariamente durante o recozimento dos cordões de solda. 
As medidas de tamanho de grão após os tratamentos térmicos com seus respectivos desvios padrão estão apresentadas nas tabelas 14 a 17 .

Tabela 14 - Medidas dos tamanhos de grão $(\mu \mathrm{m})$. Vista frontal. Condição Solubilizado.

\begin{tabular}{cccc}
\hline Localização & 1 Passe & $\begin{array}{c}\text { 2 Passes sem } \\
\text { Inversão } \\
\text { TG }\end{array}$ & $\begin{array}{c}\text { 2 Passes com } \\
\text { Inversão }\end{array}$ \\
\hline Avanço & TG & TG & (G, \\
Centro & $67,9 \pm 11,5$ & $93,3 \pm 11,5$ & $111,2 \pm 18,5$ \\
Retrocesso & $93,3 \pm 11,5$ & $111,1 \pm 19,2$ & $52,4 \pm 4,1$ \\
\hline
\end{tabular}

Tabela 15 - Medidas dos tamanhos de grão $(\mu \mathrm{m})$. Vista frontal. Condição Solubilizado e Envelhecido.

\begin{tabular}{cccc}
\hline Localização & $\begin{array}{c}\text { 1 Passe } \\
\text { TG }\end{array}$ & $\begin{array}{c}\text { Passes sem } \\
\text { Inversão } \\
\text { TG }\end{array}$ & $\begin{array}{c}\text { 2 Passes com } \\
\text { Inversão } \\
\text { TG }\end{array}$ \\
\hline Avanço & $144,4 \pm 50,9$ & $75,6 \pm 7,7$ & $111,8 \pm 17,3$ \\
Centro & $155,6 \pm 38,5$ & $122,2 \pm 19,2$ & $131,1 \pm 30,1$ \\
Retrocesso & $75,6 \pm 7,7$ & $111,1 \pm 19,0$ & $97,8 \pm 30,8$ \\
\hline
\end{tabular}

Tabela 16 - Medidas dos tamanhos de grão $(\mu \mathrm{m})$. Vista frontal. Condição Recozido por 2 horas.

\begin{tabular}{ccccc}
\hline & & 1 Passe & $\begin{array}{c}\text { 2 Passes sem } \\
\text { Inversão }\end{array}$ & $\begin{array}{c}\text { 2 Passes com } \\
\text { Inversão }\end{array}$ \\
Localização & & TG & TG & TG \\
\hline \multirow{2}{*}{ Avanço } & Grãos Alongados & $11,1 \pm 0,6$ & $18,1 \pm 3,6$ & $13,9 \pm 2,4$ \\
& Grãos Equiaxias & $6,9 \pm 0,2$ & $6,8 \pm 0,1$ & $8,1 \pm 1,3$ \\
Centro & & $6,9 \pm 0,2$ & $8,6 \pm 1,4$ & $7,4 \pm 0,9$ \\
\multirow{2}{*}{ Retrocesso } & Grãos Alongados & $16,4 \pm 2,0$ & $17,2 \pm 0,9$ & $16,2 \pm 3,4$ \\
& Grãos Equiaxiais & $6,9 \pm 0,2$ & $8,4 \pm 0,6$ & $6,9 \pm 0,5$ \\
\hline
\end{tabular}

Tabela 17 - Medidas dos tamanhos de grão $(\mu \mathrm{m})$. Vista frontal. Condição Recozido por 8 horas.

\begin{tabular}{ccccc}
\hline & & 1 Passe & $\begin{array}{c}\text { 2 Passes sem } \\
\text { Inversão }\end{array}$ & $\begin{array}{c}\text { 2 Passes com } \\
\text { Inversão }\end{array}$ \\
Localização & & TG & TG & TG \\
\hline \multirow{2}{*}{ Avanço } & Grãos Alongados & $12,3 \pm 2,7$ & $17,9 \pm 2,3$ & $12,3 \pm 2,7$ \\
\cline { 3 - 4 } Centro & Grãos Equiaxias & $7,8 \pm 2,0$ & $10,8 \pm 3,8$ & $7,9 \pm 0,7$ \\
\multirow{2}{*}{ Retrocesso } & & $8,3 \pm 1,4$ & $9,2 \pm 1,4$ & $8,6 \pm 0,2$ \\
& Grãos Alongados & $8,3 \pm 1,4$ & $17,4 \pm 4,5$ & $17,4 \pm 2,4$ \\
& Grãos Equiaxiais & $9,2 \pm 1,4$ & $9,1 \pm 1,3$ & $7,3 \pm 0,3$ \\
\hline
\end{tabular}


Analisando-se as tabelas nota-se que os tratamentos térmicos de solubilização e envelhecimento e somente de solubilização tiveram nítida influência sobre os tamanhos de grão nas áreas recristalizadas analisadas, sendo que os maiores grãos foram obtidos com o tratamento de solubilização e envelhecimento.

Estes resultados podem ser explicados pela ausência de precipitados ancorando os contornos de grão nos dois tratamentos, seguido de um envelhecimento em baixa temperatura, que provavelmente auxiliou na continuação do crescimento de grão.

\subsubsection{Medida do tamanho dos grãos equiaxiais na ZTMA}

Observando-se as tabelas de 14 a 17 e considerando-se somente a evolução dos grãos equiaxiais, na região da ZTMA e do centro do cordão, nos tratamentos térmicos de recozimento de duas horas e oito horas, observa-se a tendência de um maior tamanho de grão no centro do cordão e de menores grãos na região de retrocesso. Os tamanhos de grãos com dois passes apresentam um tamanho superior ao de um passe e dois passes com inversão. Este desenvolvimento dos tamanhos de grãos também esta relacionado com os tamanhos de grãos iniciais obtidos na condição como soldado. A figura 59 apresenta estes resultados.

A aparente redução de tamanho de grão para 2 horas de recozimento é explicada pelo erro da medida, pois ambas médias se encontram no mesmo intervalo.

A condição dois passes sem inversão apresentou o maior tamanho de grão equiaxial. O segundo passe no mesmo sentido irá repetir as direções e os sentidos de deformação ocorridos no primeiro passe, porém com uma microestrutura fina e já 
recristalizada. Este passe elimina heterogeneidades na deformação e solubiliza os precipitados, ocorrendo um maior crescimento de grãos recristalizados do que de nucleação de novos grãos recristalizados. Já na soldagem com inversão de sentido no segundo passe os grãos são menores. Com o aquecimento durante a deformação, ocorre a solubilização dos precipitados e na condição de dois passes sem inversão o grão cresce.

$\mathrm{Na}$ condição de dois passes com inversão ocorrem alterações nas direções e sentidos de fluxo de material. As heterogeneidades de deformação são acentuadas e as deformações mais expressivas levando a recristalização dinâmica do material, como na condição do primeiro passe.

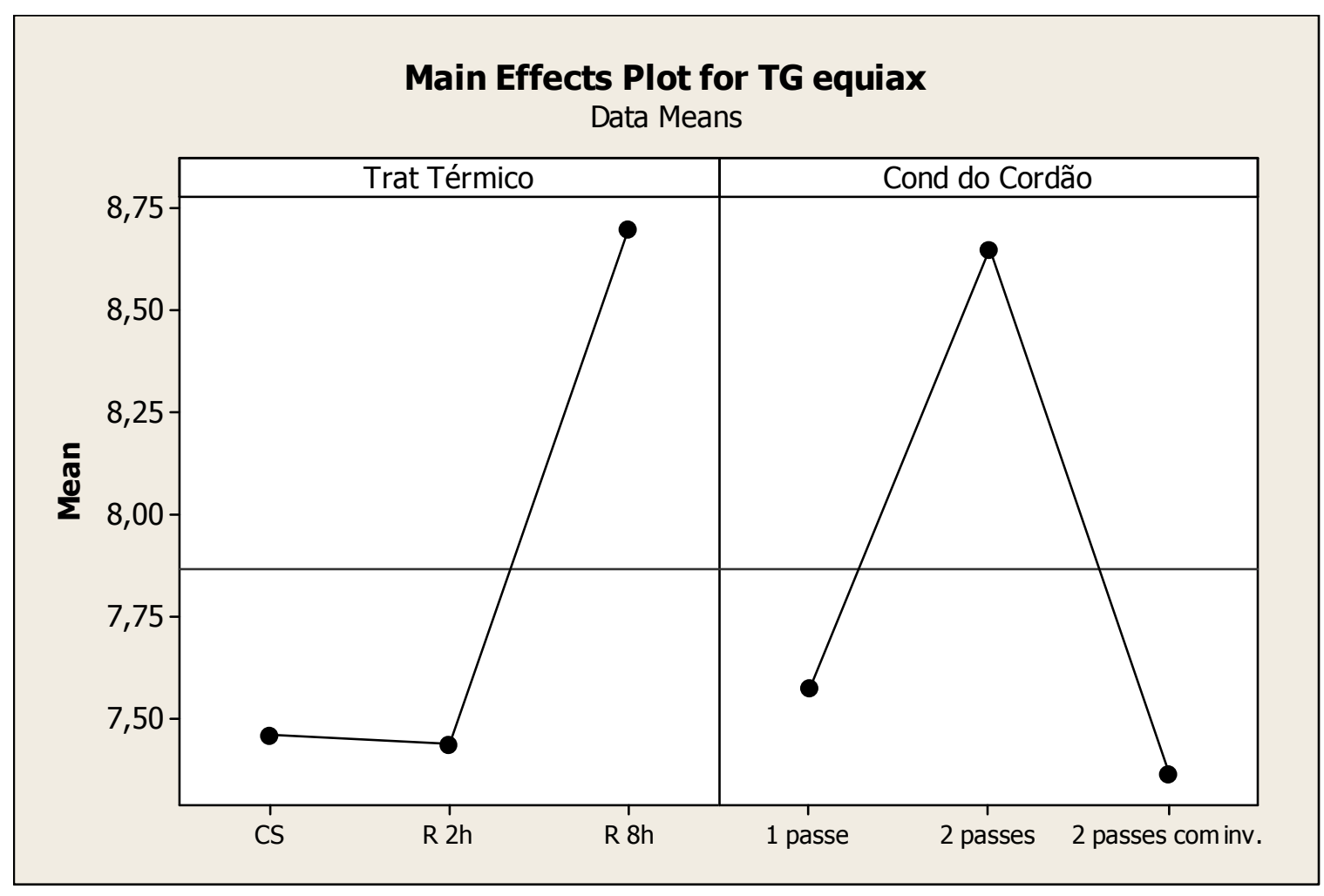

Figura 59 - Efeitos do tratamento térmico de recozimento, condição do cordão e localização no tamanho de grão equiaxial.

Pela análise da tabela 18 de ANOVA os efeitos significativos com $0,1 \%$ de erro são o tempo de recozimento e a condição de soldagem. 
Tabela 18 - Cálculo de ANOVA para os fatores tratamento térmico, condição de soldagem do cordão e localização.

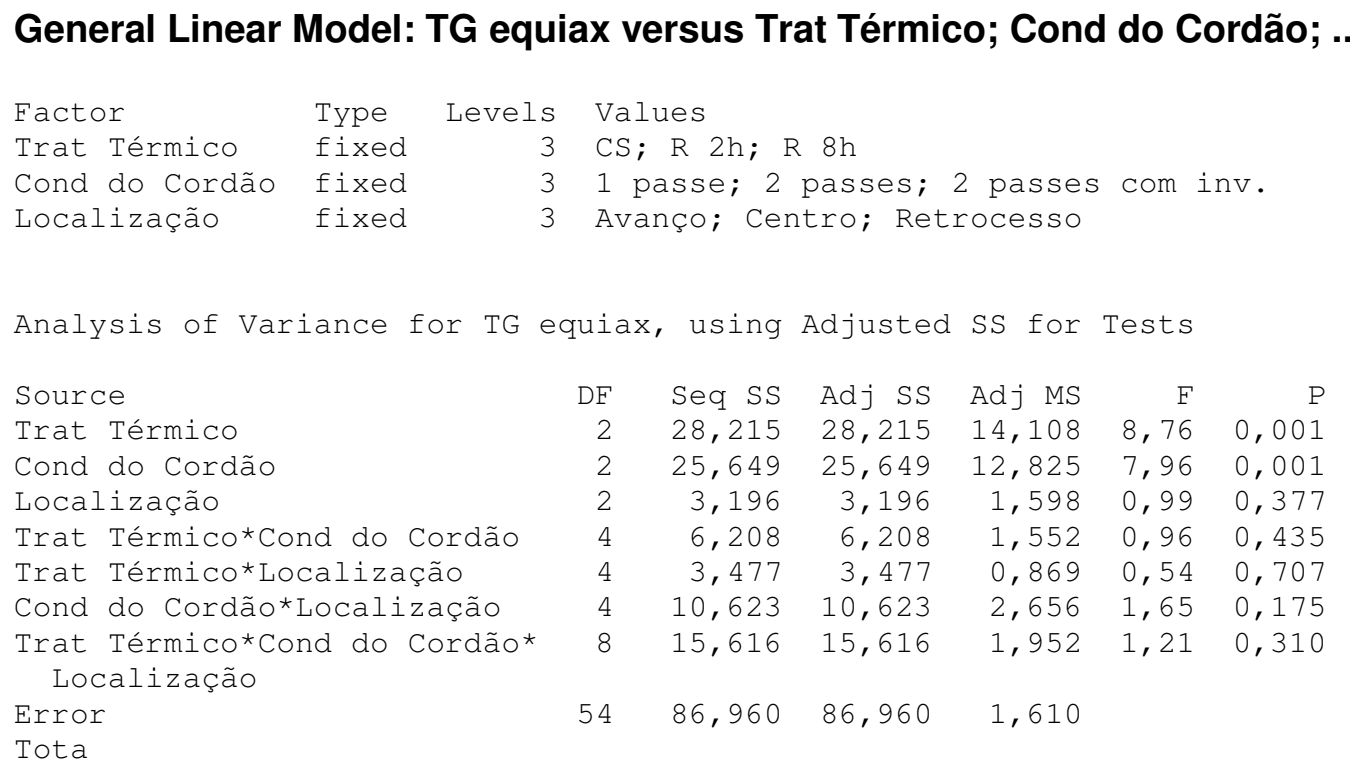

\subsubsection{Medida do tamanho dos grãos alongados na ZTMA}

Os efeitos dos tratamentos térmicos, considerando-se a evolução dos grãos alongados na ZTMA e os equiaxiais no centro do cordão são apresentados na figura 60.

Os tamanhos de grão no recozimento apresentaram pouca variação entre os tratamentos de duas e oito horas, desconsiderando-se a área de recristalização secundária.

A diferença dos tamanhos de grão entre o avanço e o retrocesso pode ser explicada pelos tamanhos de grão iniciais.

A condição de soldagem, sem considerar as interações, não apresentou nenhuma influência no crescimento dos grãos alongados na ZTMA. 


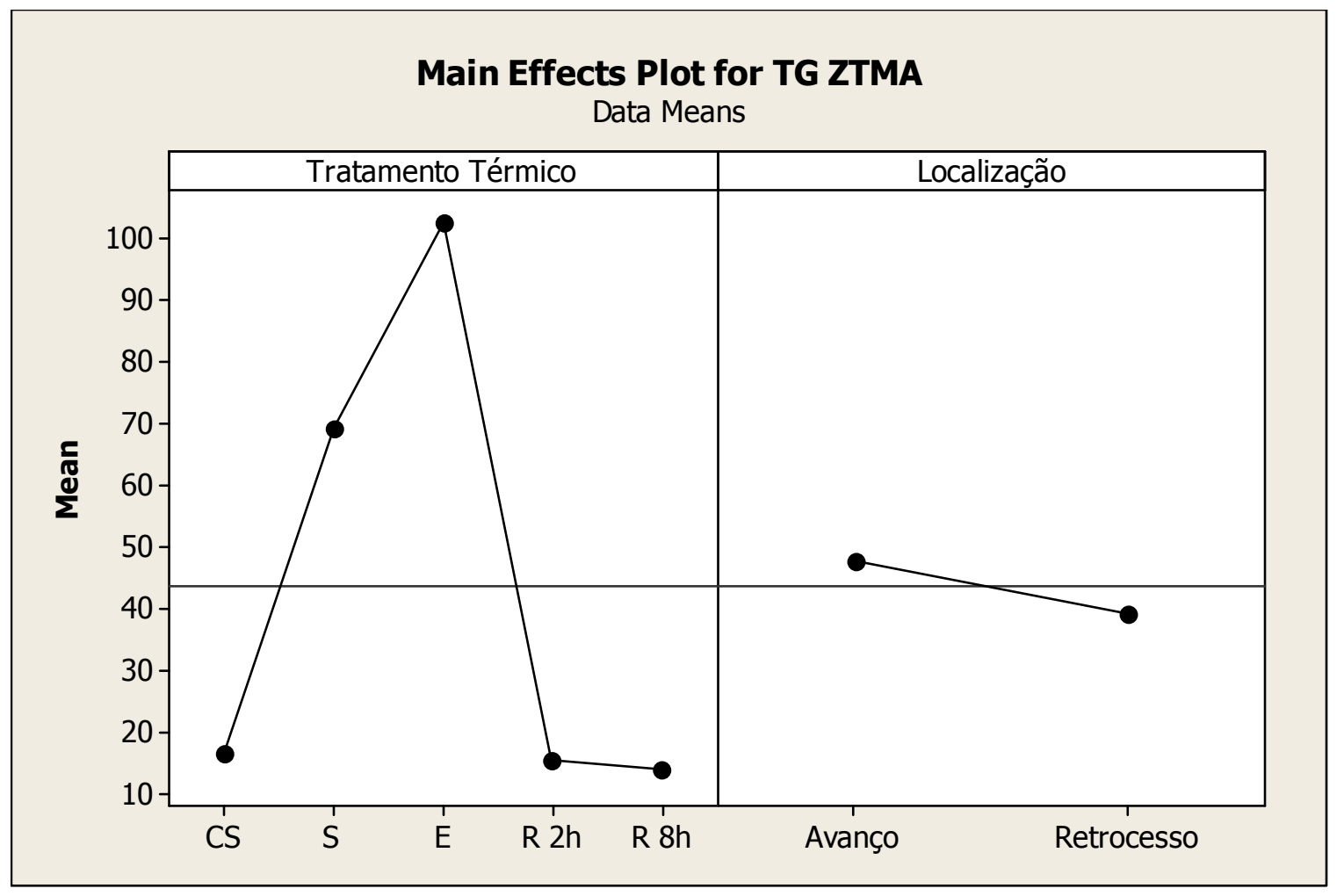

Figura 60 - Efeitos do tratamento térmico e localização no tamanho de grão da ZTMA.

A interação dos fatores significativos 'localização no cordão' e 'tratamentos térmicos' é apresentada na figura 61. Esta interação mostra que após os tratamentos térmicos a diferença entre os tamanhos de grão da região de avanço e retrocesso diminuíram na condição de dois passes com inversão e praticamente as médias dos tamanhos de grão destas regiões se igualaram na condição de soldagem de dois passes sem inversão. A diferença máxima entre estas regiões foi obtida na condição de um passe. Isto é explicado pela deformação que estas regiões são submetidas. A condição de um passe sem tratamento térmico apresentou os maiores tamanhos de grão na região de retrocesso. Nas condições de dois passes a deformação foi severa e os grãos alongados armazenam mais energia para a recristalização e crescimento de grão, muito acima do que na condição de um passe. 


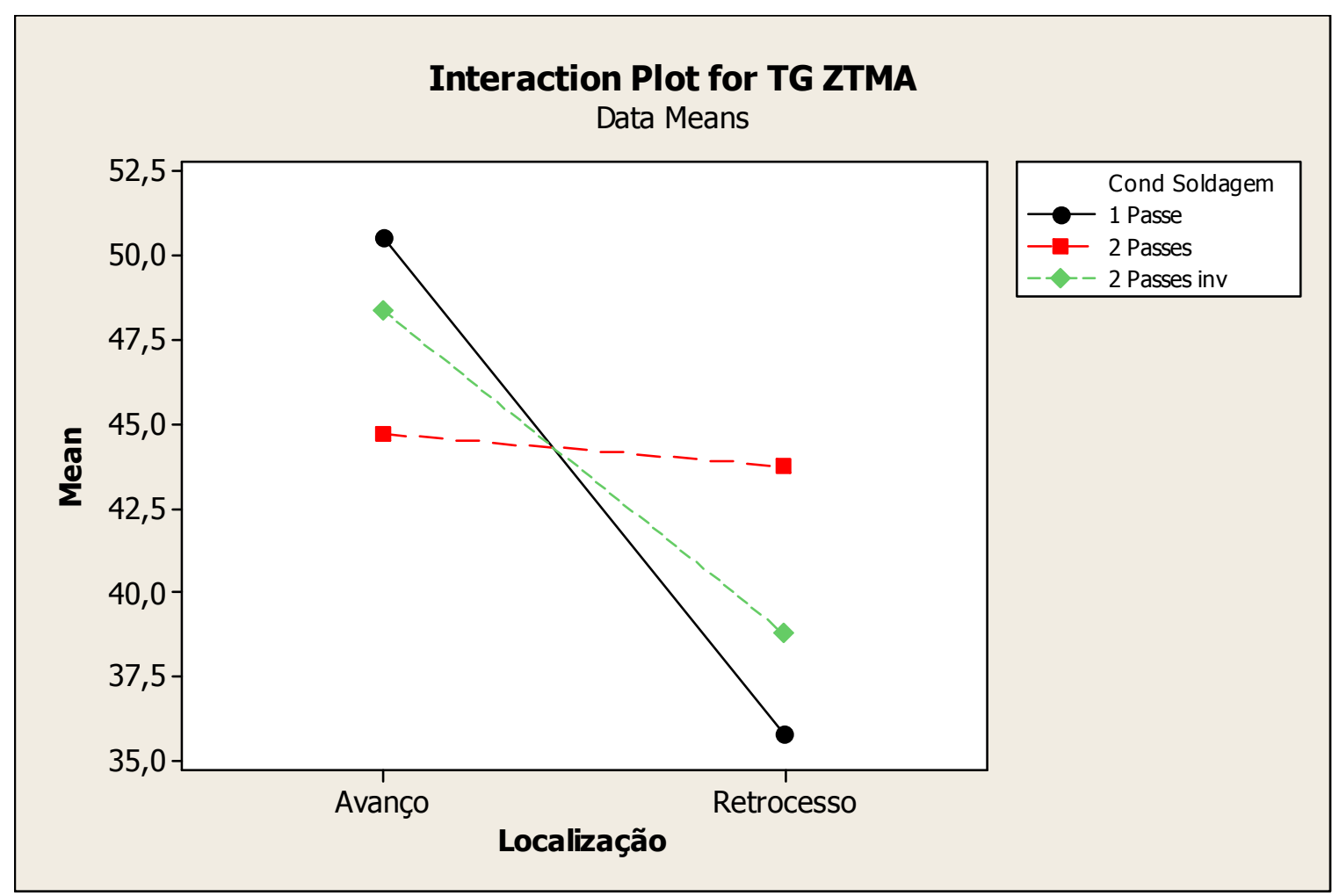

Figura 61 - Efeitos das interações entre localização no cordão e condição de soldagem e recozimento $2 \mathrm{~h}$ e $8 \mathrm{~h}$.

A tabela 19 apresenta a análise de variância ANOVA para fatores Tratamento Térmico, Condições de Soldagem e Localização, para grãos alongados na ZTMA. Para um nível de significância de $0,1 \%$ é possível se afirmar a influência da localização, do tratamento térmico e das interações entre o tratamento térmico e a condição de soldagem. Os três fatores apresentaram também significância na interação. O terceiro fator é o tratamento térmico, e como estes apresentam tempos e temperaturas diferentes, irá ocorrer a interação para o resultado de tamanho de grão.

A diferença obtida nos tamanhos de grão após o tratamento térmico é explicado pelos tamanhos de grão iniciais. O lado de retrocesso que apresentava o menor tamanho de grão na condição como soldado é também o menor tamanho de grão após a condição tratada. 
Tabela 19 - Tabela de ANOVA para os fatores Tratamento Térmico, Condições de Soldagem e Localização, para grãos alongados na ZTMA.

\begin{tabular}{|c|c|c|c|c|c|c|c|c|}
\hline Factor & Type & Levels & \multicolumn{6}{|c|}{ Values } \\
\hline Tratamento Térmico & fixed & 5 & \multicolumn{6}{|c|}{$\mathrm{CS} ; \mathrm{S} ; \mathrm{E} ; \mathrm{R} 2 \mathrm{~h} ; \mathrm{R} 8 \mathrm{~h}$} \\
\hline Cond Soldagem & fixed & 3 & \multicolumn{6}{|c|}{1 Passe; 2 Passes; 2 Passes inv } \\
\hline Localização & fixed & 2 & \multicolumn{6}{|c|}{ Avanço; Retrocesso } \\
\hline \multicolumn{9}{|c|}{ Analysis of Variance for TG ZTMA, using Adjusted SS for Tests } \\
\hline Source & & & $\mathrm{DF}$ & Seq SS & Adj SS & Adj MS & $\mathrm{F}$ & $\mathrm{P}$ \\
\hline Tratamento Térmico & & & 4 & 117194,2 & 117194,2 & 29298,6 & 175,92 & 0,000 \\
\hline Cond Soldagem & & & 2 & 17,4 & 17,4 & 8,7 & 0,05 & 0,949 \\
\hline Localização & & & 1 & 1613,7 & 1613,7 & 1613,7 & 9,69 & 0,003 \\
\hline Tratamento Térmico* & Cond Sc & ldagem & 8 & 1909,8 & 1909,8 & 238,7 & 1,43 & 0,202 \\
\hline Tratamento Térmico* & Localiz & ação & 4 & 2763,5 & 2763,5 & 690,9 & 4,15 & 0,005 \\
\hline Cond Soldagem*Local & ização & & 2 & 732,0 & 732,0 & 366,0 & 2,20 & 0,120 \\
\hline $\begin{array}{l}\text { Tratamento Térmico* } \\
\text { Localização }\end{array}$ & Cond Sc & ldagem* & 8 & 8162,5 & 8162,5 & 1020,3 & 6,13 & 0,000 \\
\hline Error & & & 60 & 9992,9 & 9992,9 & 166,5 & & \\
\hline Total & & & 89 & 142386,0 & & & & \\
\hline
\end{tabular}




\subsection{Difração de elétrons retroespalhados (EBSD)}

\subsubsection{Metal de base}

A figura 62 apresenta 0 mapa de orientação para o metal de base. Ele permite a rápida constatação da presença de textura, associando esta com a morfologia da amostra em estudo. Este mapa indica pela predominância da cor, conforme a escala, uma textura na direção $<001>$.

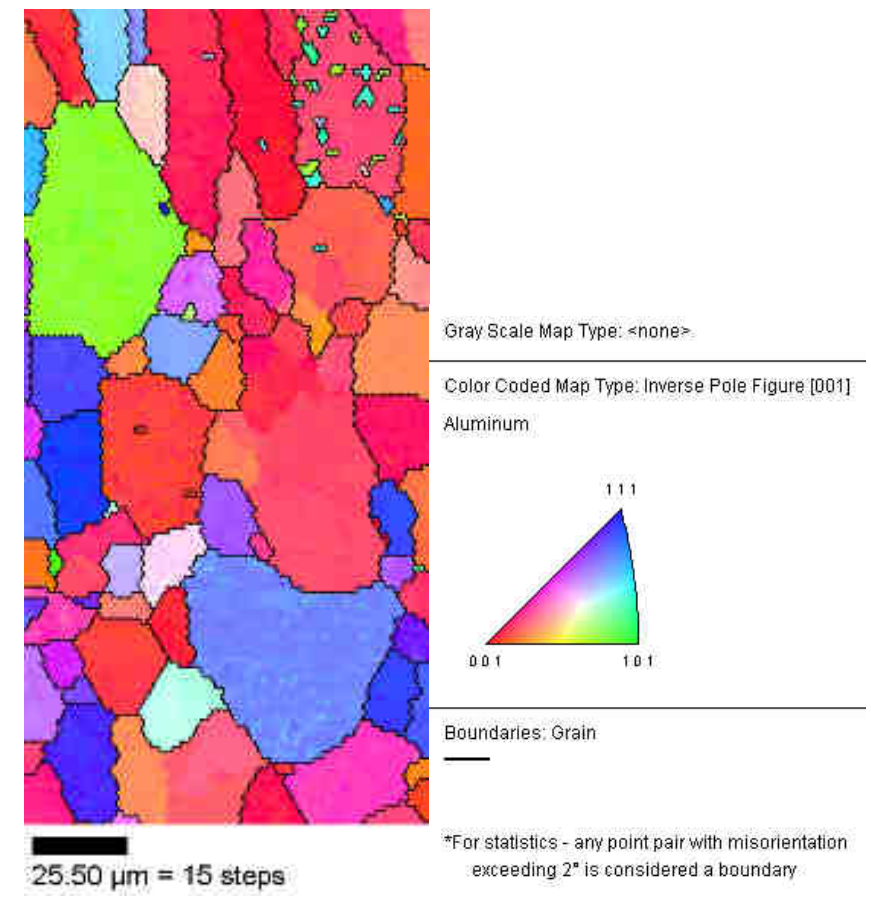

Figura 62 - Mapa de orientação do grão. Material de base apresentando uma textura na direção $<001>$.

A figura 63 apresenta o mapa referente ao índice de qualidade (IQ) do ensaio. Uma escala cinza é atribuída para cada ponto analisado, sendo branco para o melhor ponto e preto para o pior. Este mapa revela uma boa qualidade de coleta de dados. Os pontos escuros na região superior da amostra podem ser de precipitados danificados durante a preparação da amostra e que não comprometem a análise uma vez que foram utilizados os pontos com índice de qualidade superior a $0,1^{(105)}$. 


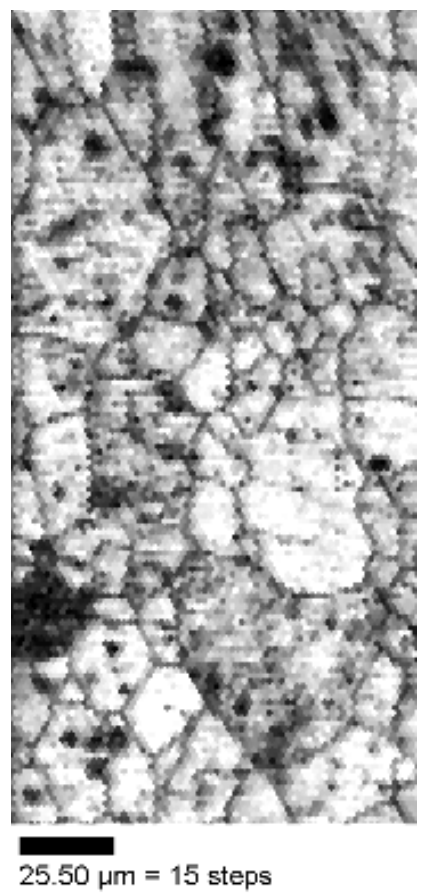

Figura 63 - Mapa de índice de qualidade de ensaio (IQ). Material de Base.

A figura 64 apresenta a orientação entre os grãos da área analisada. Neste gráfico é possível identificar duas distribuições de tamanho de grão: uma centrada próximo de uma orientação de $50^{\circ}$ e outra próximo de 15․ Este tipo de perfil de orientação é encontrado em ligas de alumínio AA6063 e AA6082 extrudadas e solubilizadas ${ }^{(60)}$.

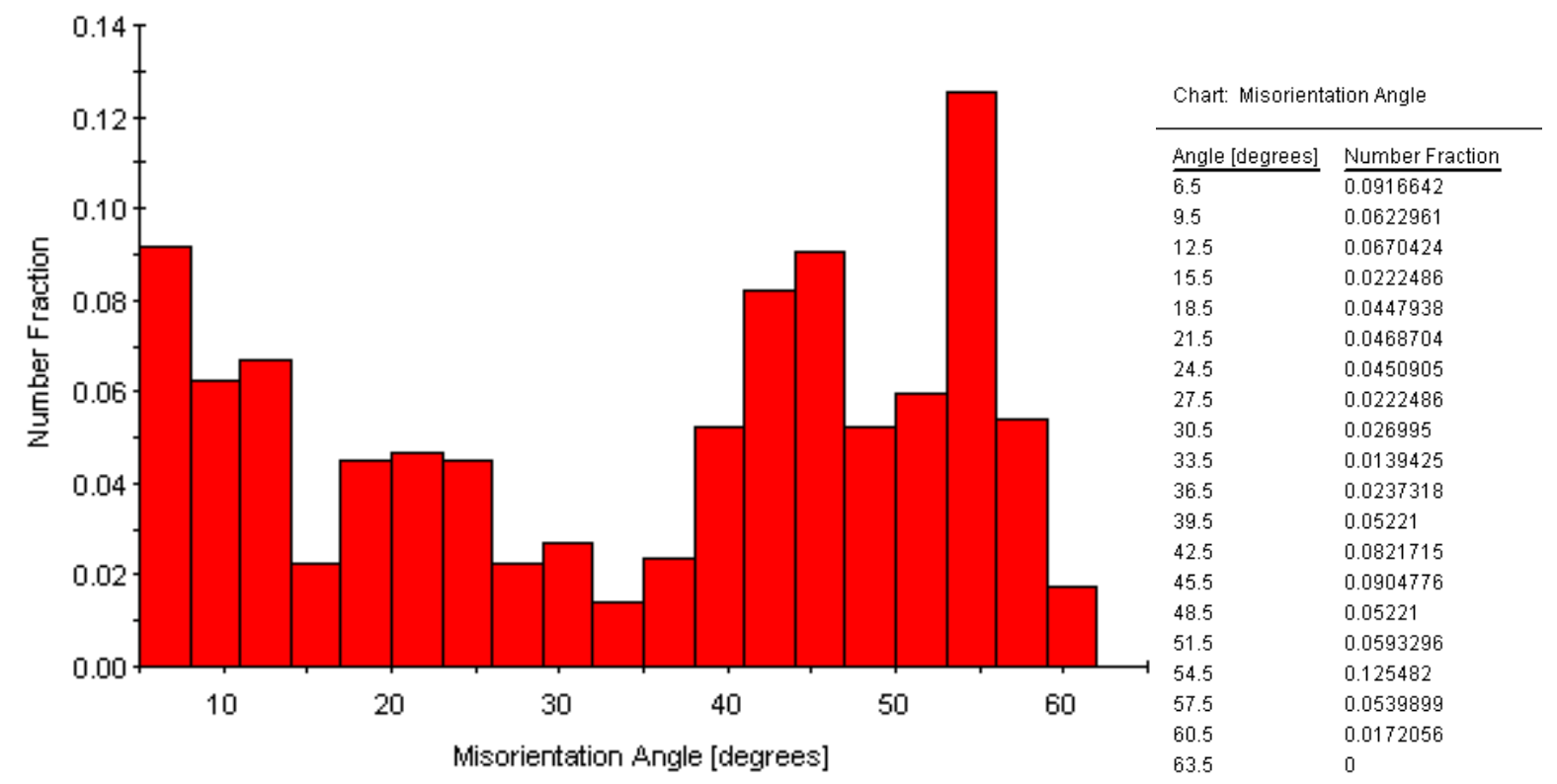

Figura 64 - Diferença de orientação entre grãos do material de base. 
Com base nos dados da figura 64 foi construída a porcentagem acumulada das diferenças de orientação entre os grãos para o metal de base, apresentada na figura 65. Foram ressaltadas as porcentagens acumuladas até uma diferença de orientação de $5^{\circ}(7 \%)$, de $15^{\circ}$ (24\%) e o valor da orientação média, para $50 \%$ de fração acumulada (38ํ).

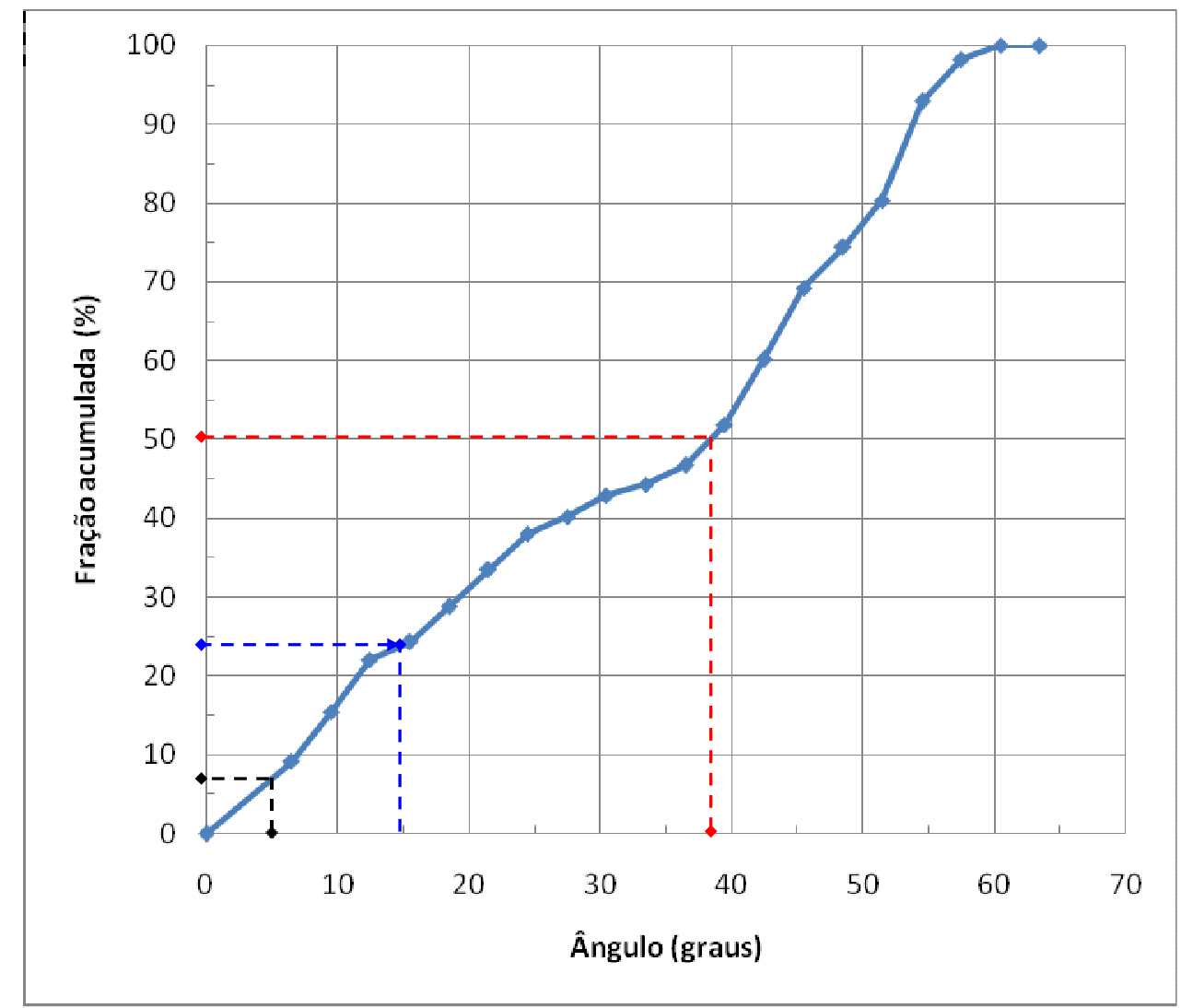

Figura 65 - Diferença de orientação entre grãos do material de base.

A figura 66 apresenta a função de distribuição de orientação (FDO) obtida por EBSD para o material de base. Para $\Phi_{2}=0$ e e $\Phi_{2}=45^{\circ}$ identificam-se as texturas do tipo Cubo $(C)\left\{\begin{array}{lll}1 & 0 & 0\end{array}\right\}\left(\begin{array}{llll}0 & 0 & 1\end{array}\right)$, que são típicas de alumínio recristalizado ${ }^{(106)}$. Estes resultados estão de acordo com a condição inicial do metal de base, que era uma barra chata extrudada e solubilizada. 


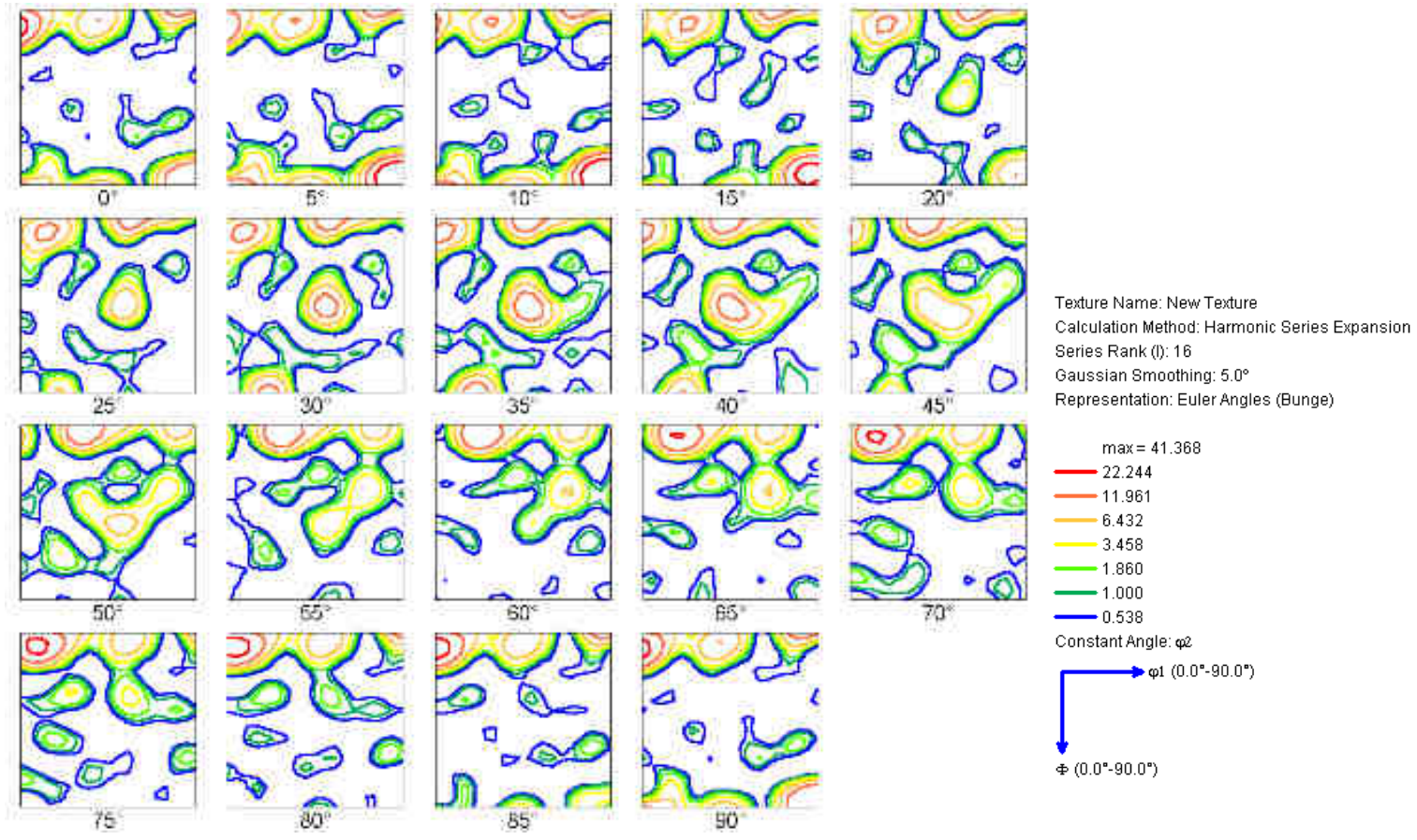

Figura 66 - FDO (EBSD) obtida para o material de base.

O método de EBSD também permite o cálculo dos tamanhos de grão do material, como apresentado na figura 67 . Neste caso, contornos de grão com mais de $2^{\circ}$ são considerados na estatística.

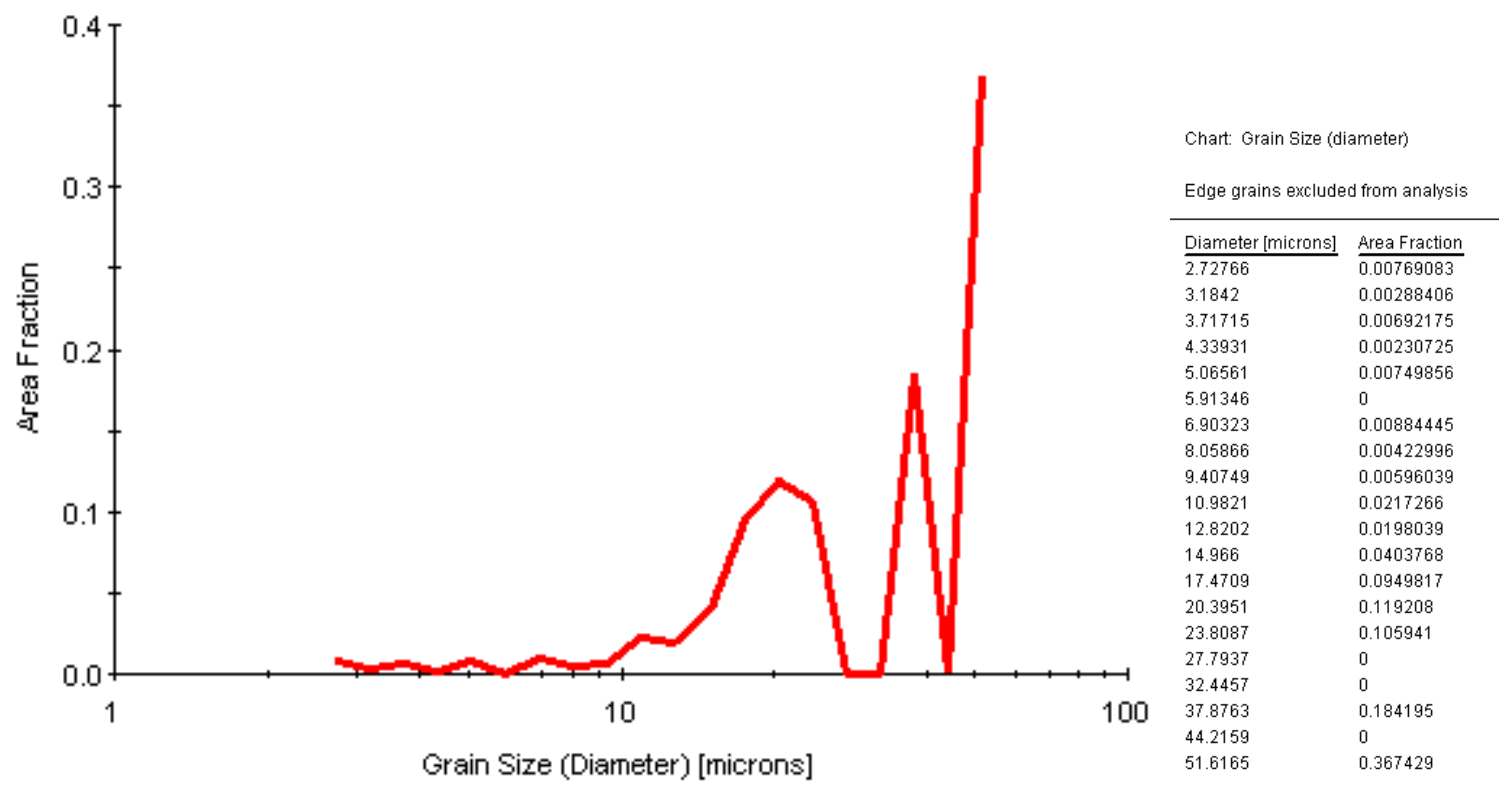

Figura 67 - Tamanho de grão do metal de base.

Com base nos dados da figura 67 foi construída a porcentagem acumulada dos tamanhos de grão do metal de base, apresentada na figura 68. Foi indicado o valor 
do tamanho de grão para uma porcentagem acumulada de $50 \%$. O resultado obtido está próximo de $34 \mu \mathrm{m}$.

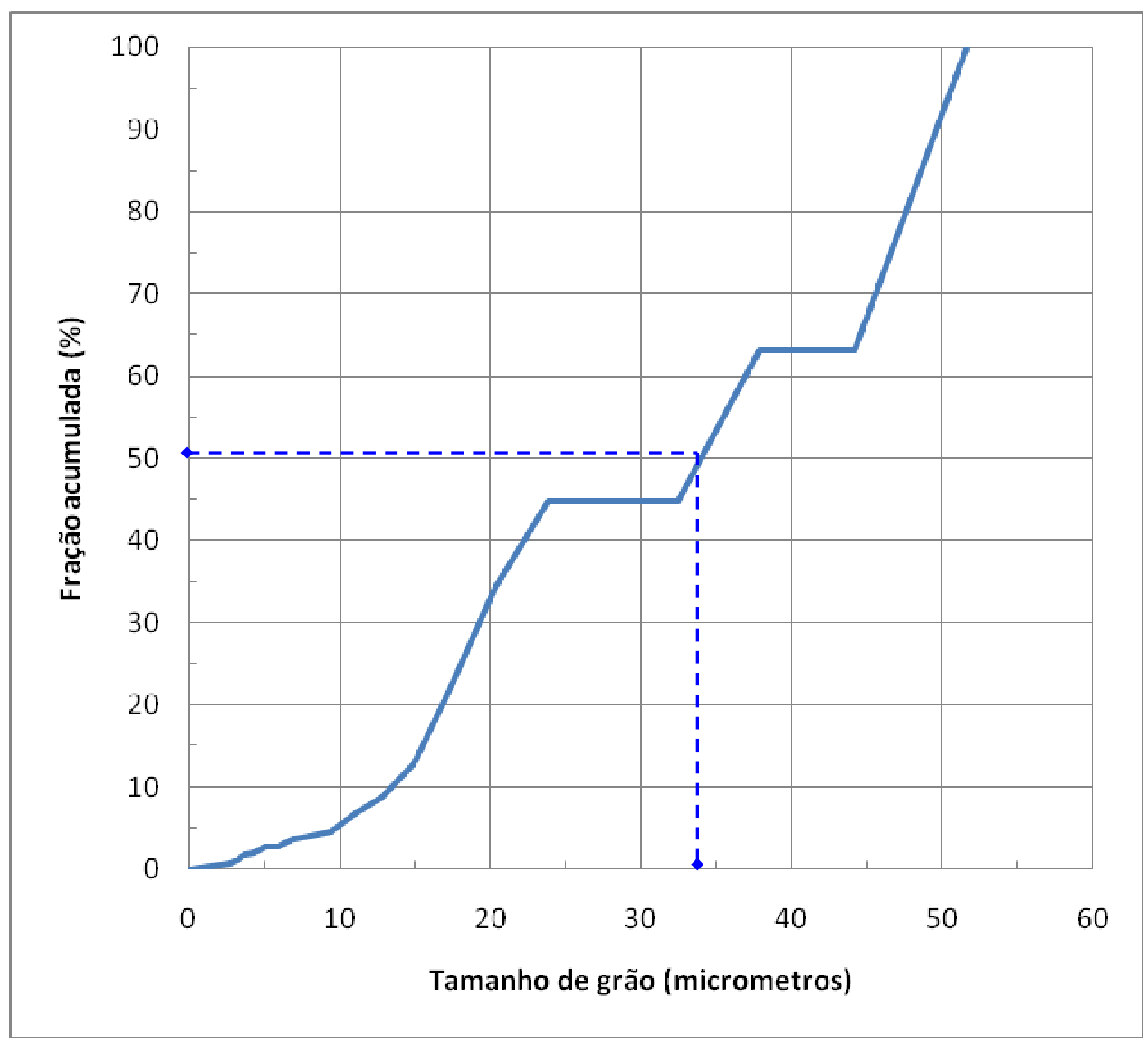

Figura 68 - Porcentagem acumulada da distribuição dos tamanhos de grão obtidos por EBSD do Material de Base.

O valor obtido por microscopia ótica e análise de imagens também apresentou um tamanho de grão de $34 \mu \mathrm{m}$.

Serão apresentados, a seguir, os resultados obtidos para as condições soldadas de 1 passe, 2 passes sem inversão, 2 passes com inversão,sem tratamento térmico posterior. E por fim serão apresentados os resultados obtidos para dois passes sem inversão após 8 horas de recozimento. 


\subsubsection{Soldagem com um único passe, sem tratamento térmico}

\subsubsection{Lado do avanço}

A figura 69 apresenta o mapa de orientações para a condição de um passe. Nesta figura é possível identificar alguns grãos muito finos da ordem de $2 \mu \mathrm{m}$ de diâmetro.

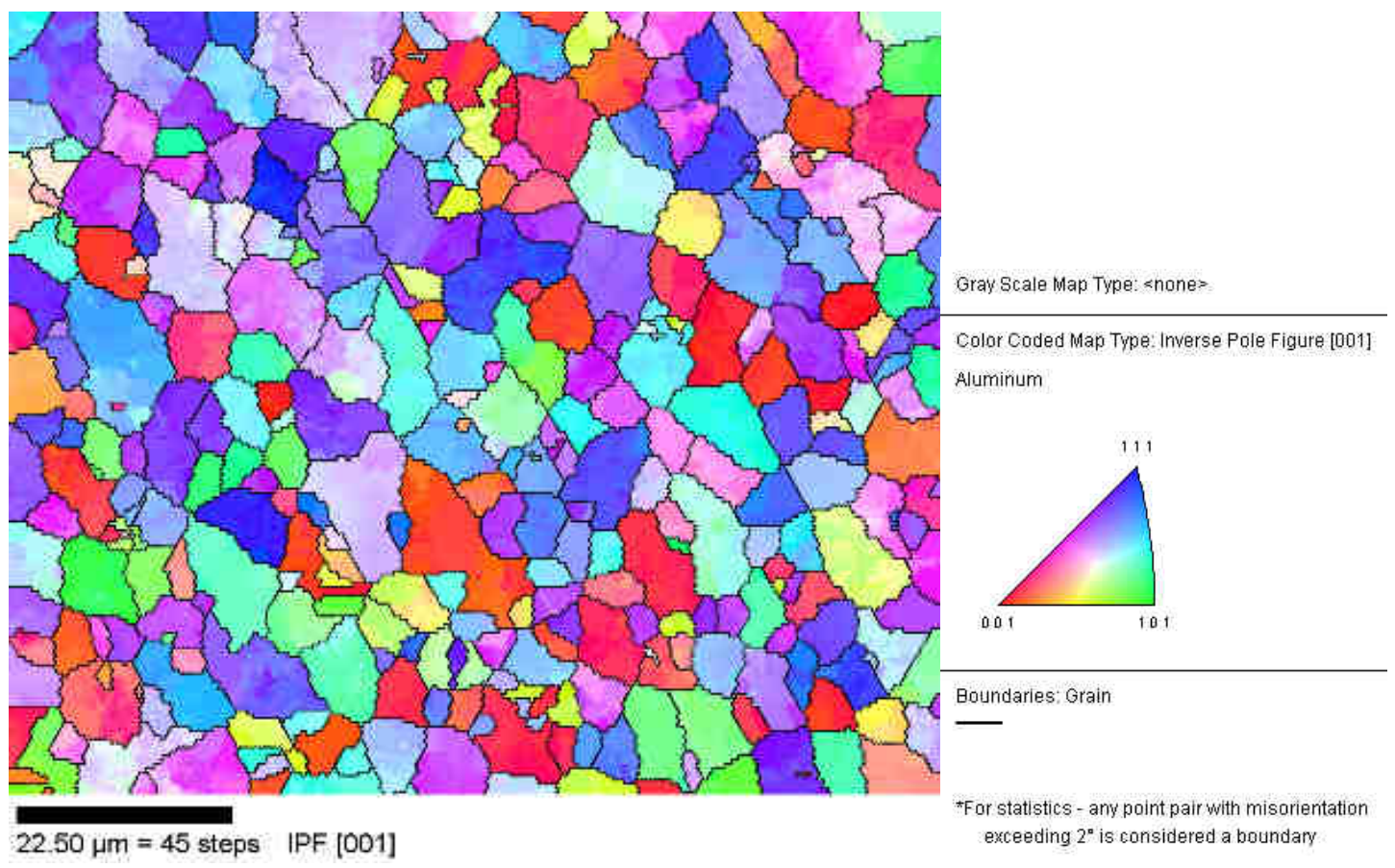

Figura 69 - Mapa de orientação de grão para a condição de um passe. Região de avanço da ferramenta.

A figura 70 apresenta a distribuição da orientação entre os grãos. Desta figura observa-se que $24 \%$ dos grãos têm uma orientação com seu vizinho abaixo de $15^{\circ}$. Ou seja, $24 \%$ dos contornos de grão são de baixo ângulo. A quantidade predominante dos grãos neste caso é de contornos de alto ângulo. Os grãos refinados nesta região e a alta fração de contornos de grãos com diferenças de orientação elevadas sugerem a recristalização dinâmica desta região. 
A fração de contornos de baixo ângulo pode ter sido obtida por recuperação dinâmica, tendo os dois mecanismos atuados durante a soldagem do cordão, para reduzir a energia armazenada da deformação a quente.

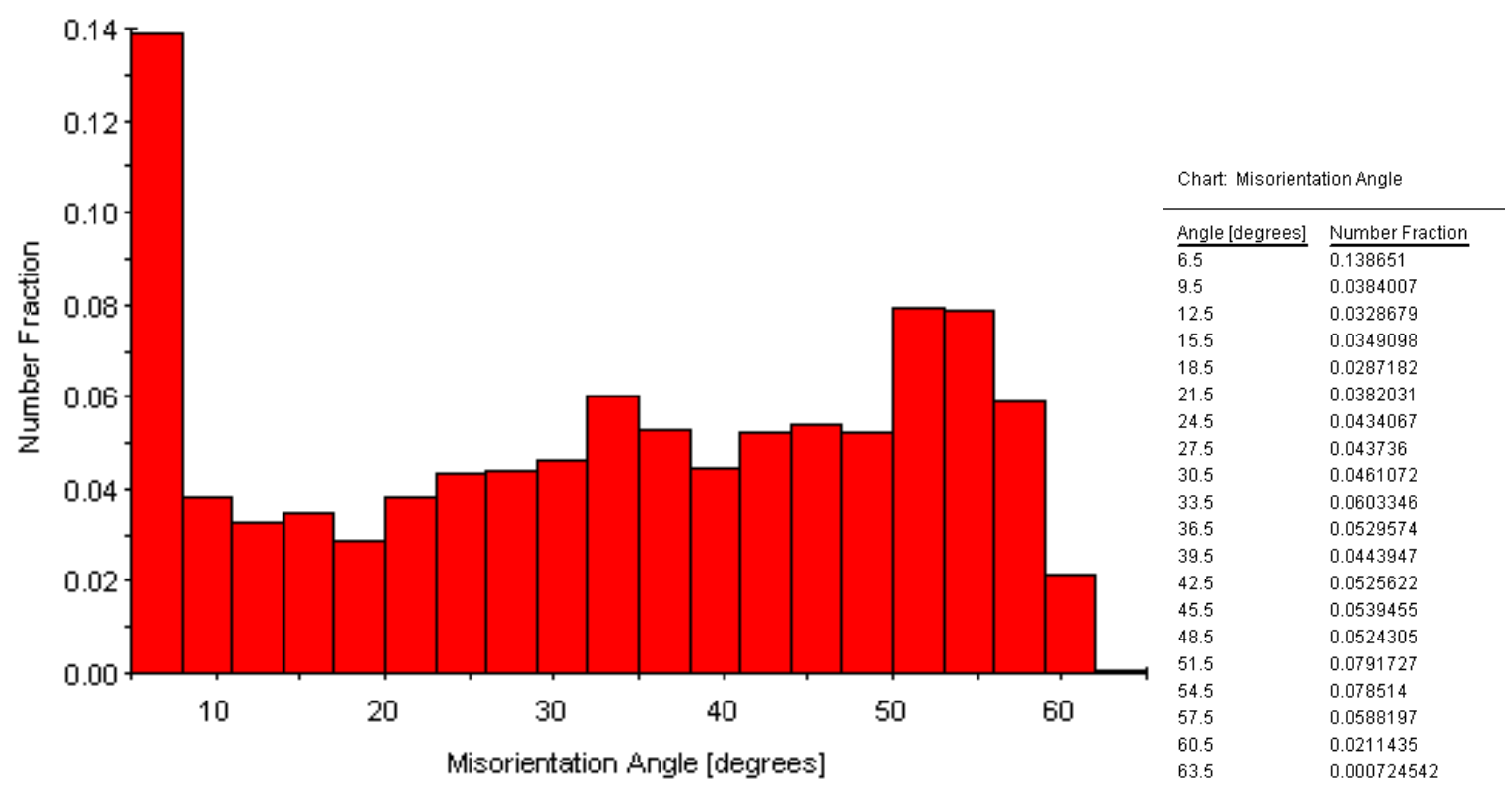

Figura 70 - Diferença de orientação dos grãos para a condição de um passe. Região de avanço da ferramenta.

A figura 71 apresenta a função de distribuição de orientação (FDO) obtida por EBSD para 1 passe na região de avanço. Os resultados obtidos mostram uma textura fraca do tipo Cubo (C) $\left\{\begin{array}{lll}1 & 0 & 0\end{array}\right\}\left(\begin{array}{lll}0 & 0 & 1\end{array}\right)$, com o parâmetro máximo de 23,7. A região de avanço da ferramenta é uma região com fluxo de material proveniente de várias direções e junto com o processo de recristalização dinâmica, os grãos não adquirem uma orientação preferencial forte.

Esta textura pode ter sido proveniente da recristalização, uma vez que ela é típica para alumínio recristalizado. 

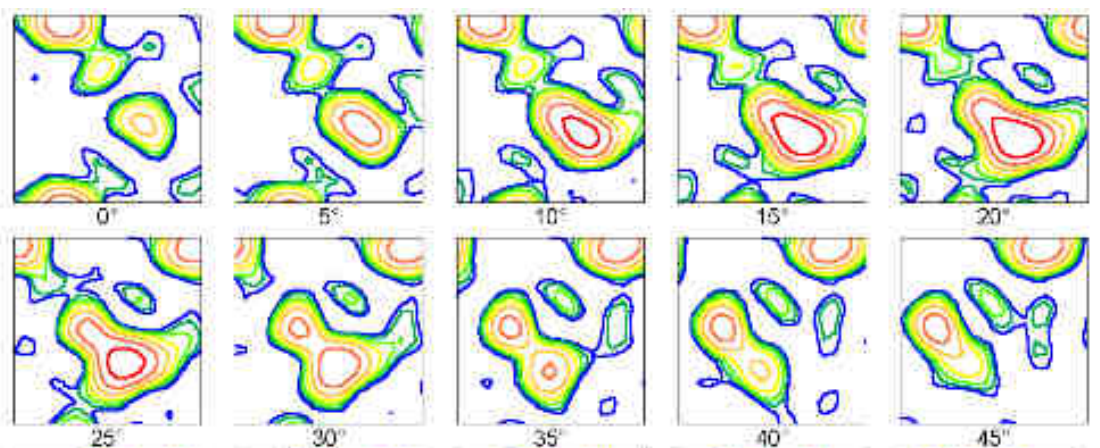

Texture Name: New Texture

Calculation Method: Harmonic Series Expansion Series Rank (1): 16

Gaussian Smoothing: $5.0^{\circ}$

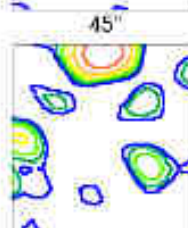

Representation: Euler Angles (Bunge)
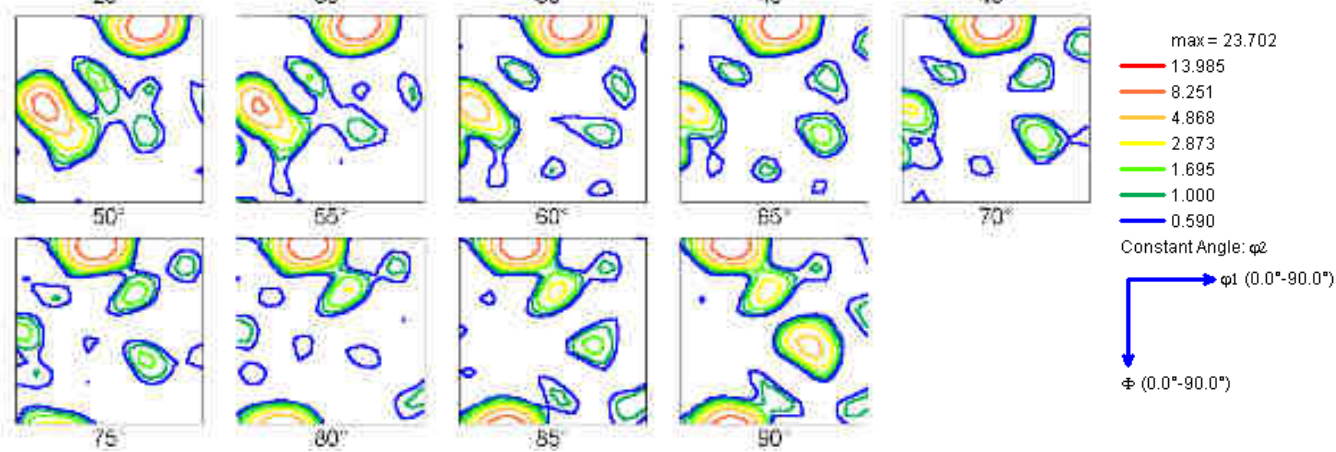

Figura 71 - FDO (EBSD) obtida para a condição de um passe. Região de avanço da ferramenta.

A figura 72 apresenta a medição dos grãos para esta região. A medida obtida por microscopia ótica se encontra dentro deste intervalo.

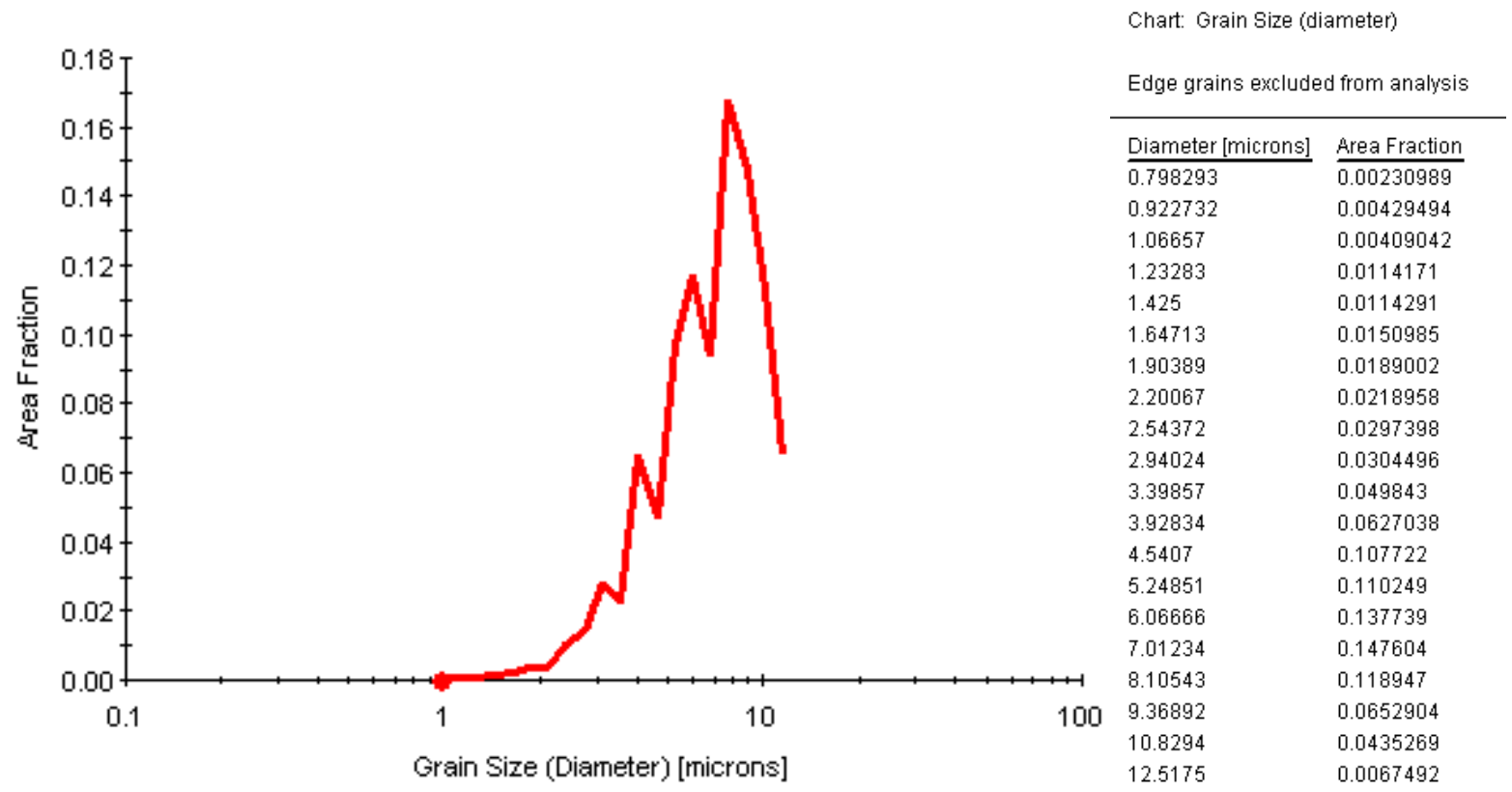

Figura 72 - Tamanho de grão para a condição de um passe. Região de avanço da ferramenta. 


\subsubsection{Lado do retrocesso}

A figura 73 apresenta o mapa de orientação de grão para condição de soldagem de um passe na região de retrocesso.

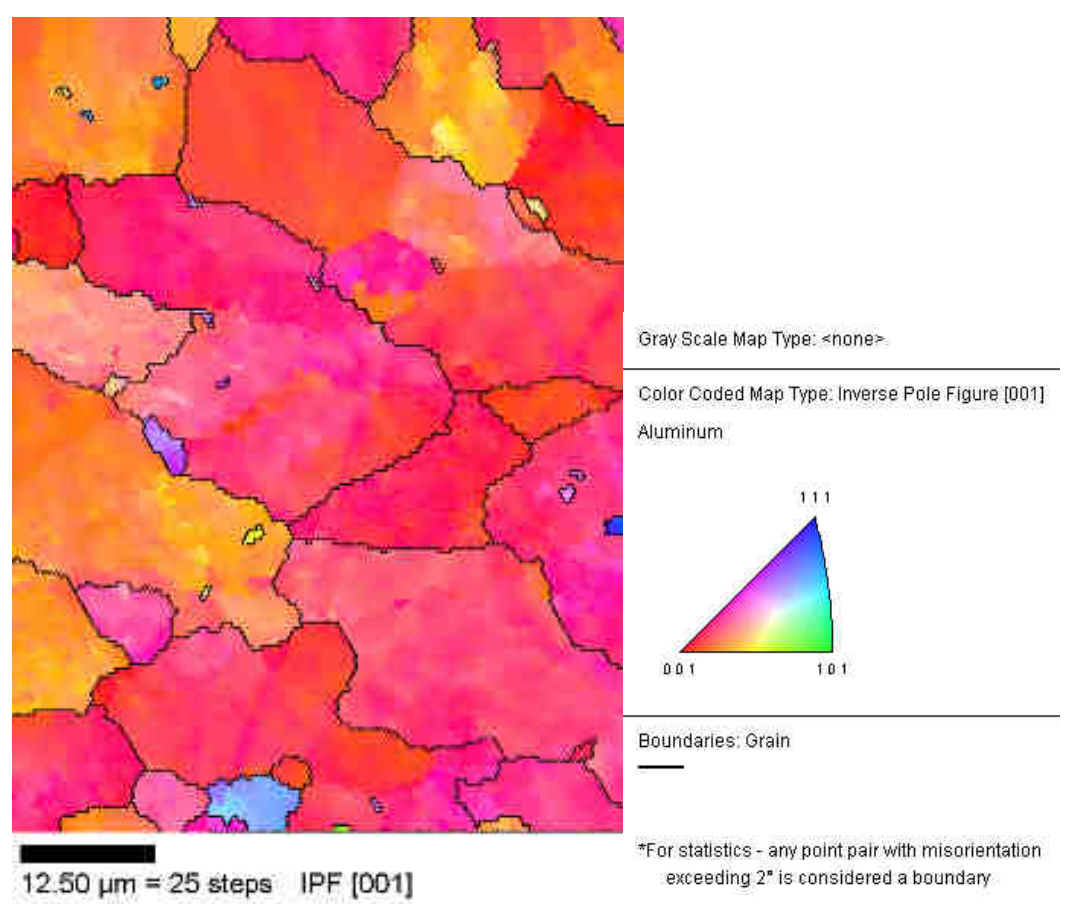

Figura 73 - Mapa de orientação de grão para a condição de um passe. Região de retrocesso da ferramenta.

A figura 74 apresenta a diferença de orientação dos grãos para a região de retrocesso da ferramenta. Esta região apresenta uma quantidade elevada de contornos de grão de baixo ângulo. Isto sugere que o mecanismo para redução da energia armazenada durante a deformação a quente foi o de recuperação dinâmica. A título de comparação, e com base nos dados das figuras 70 e 74 , foi construída a porcentagem acumulada das diferenças de orientação entre os grãos para a soldagem com um passe do lado do avanço e do retrocesso, apresentada na figura 75. Foram ressaltadas na figura as porcentagens acumuladas até uma diferença de 
orientação de $5^{\circ}$ e de $15^{\circ}$ e o valor médio da orientação da região para $50 \%$ da porcentagem acumulada..

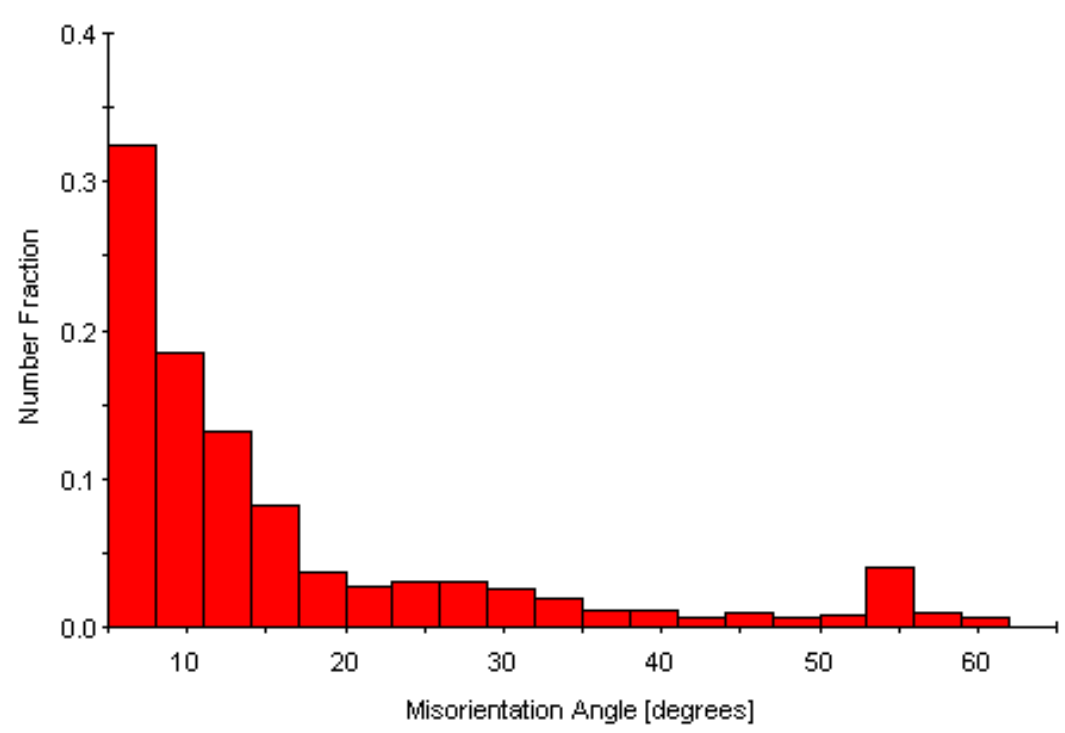

\begin{tabular}{|c|c|}
\hline Angle [degrees] & Number Fraction \\
\hline$\overline{6.5}$ & 0.323751 \\
\hline 9.5 & 0.184967 \\
\hline 12.5 & 0.131951 \\
\hline 15.5 & 0.0815269 \\
\hline 18.5 & 0.0369934 \\
\hline 21.5 & 0.0266258 \\
\hline 24.5 & 0.0301602 \\
\hline 27.5 & 0.0301602 \\
\hline 30.5 & 0.0252121 \\
\hline 33.5 & 0.0193214 \\
\hline 36.5 & 0.0113101 \\
\hline 39.5 & 0.0115457 \\
\hline 42.5 & 0.00636192 \\
\hline 45.5 & 0.00942507 \\
\hline 48.5 & 0.00636192 \\
\hline 51.5 & 0.00777568 \\
\hline 54.5 & 0.0398209 \\
\hline 57.5 & 0.00989632 \\
\hline 60.5 & 0.00683318 \\
\hline 63.5 & 0 \\
\hline
\end{tabular}

Figura 74 - Diferença de orientação dos grãos para a condição de um passe. Região de retrocesso da ferramenta.

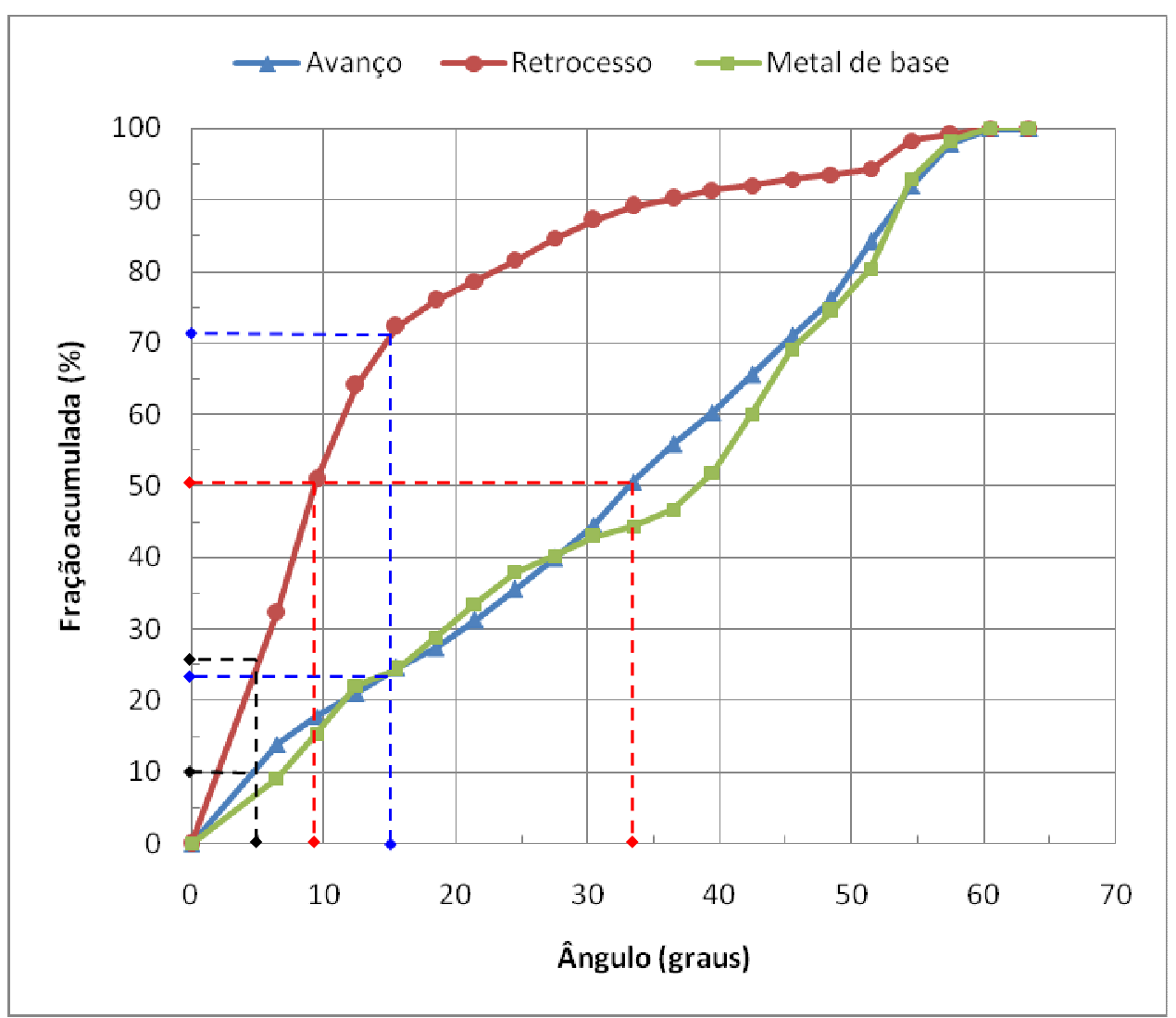

Figura 75 - Comparação entre as diferenças de orientação dos grãos do cordão de solda com um passe, no lado do avanço e do retrocesso, comparado com o metal de base. 
Com base na figura 75 têm-se os seguintes valores:

a) Avanço:

i. Porcentagem acumulada até diferença de orientação de $5^{\circ}=10 \%$;

ii. Porcentagem acumulada até diferença de orientação de $15^{\circ}=23 \%$;

iii. Valor médio da orientação da região $=33^{\circ}$.

b) Retrocesso:

i. Porcentagem acumulada até diferença de orientação de $5^{\circ}=25 \%$;

ii. Porcentagem acumulada até diferença de orientação de $15^{\circ}=71 \%$;

iii. Valor médio da orientação da região $=9^{\circ}$.

Estes resultados mostram que a porcentagem acumulada de contornos de baixo ângulo com orientação inferior a $15^{\circ}$ é maior na região de retrocesso $(71 \%)$ que na região de avanço $(23 \%)$.

Com relação aos contornos de baixo ângulo, considerados instáveis para orientações inferiores a $5^{\circ}{ }^{(63)}$, obteve-se valores de $10 \%$ para o avanço e $25 \%$ para o retrocesso. Quanto maior a quantidade destes contornos de baixo ângulo, maior a probabilidade de crescimento anormal de grãos.

Com relação a orientação média nas regiões, obteve-se os valores de $33^{\circ}$ para o avanço e 9ำ para o retrocesso. Quanto maior for a quantidade de grãos com orientação acima do valor médio, maior a probabilidade de crescimento anormal de $\operatorname{grãos}^{(63)}$.

A figura 76 apresenta a função de distribuição de orientação (FDO) obtida por EBSD para 1 passe na região de retrocesso. Os resultados obtidos mostram uma componente de textura do tipo Cubo (C) $\left\{\begin{array}{lll}1 & 0 & 0\end{array}\right)\left(\begin{array}{lll}0 & 0 & 1\end{array}\right)$, para $\Phi_{2}=45^{\circ}$ muito mais pronunciada do que no lado de avanço, com o parâmetro máximo de 91,26. Esta textura forte está relacionada com a extrusão do material nesta região. 

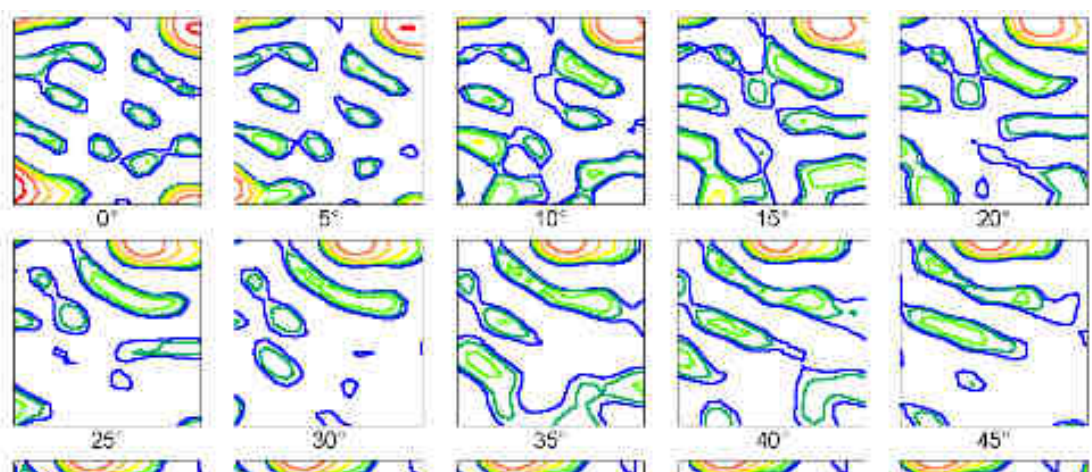

35
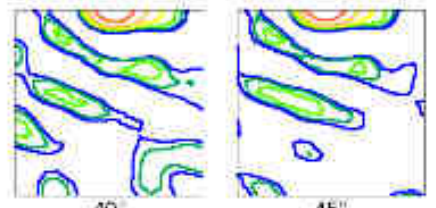

Texture Name: New Texture

Calculation Method: Harmonic Series Expansion

Series Rank (1): 16

Gaussian Smoothing: $5.0^{\circ}$

Representation: Euler Angles (Bunge)
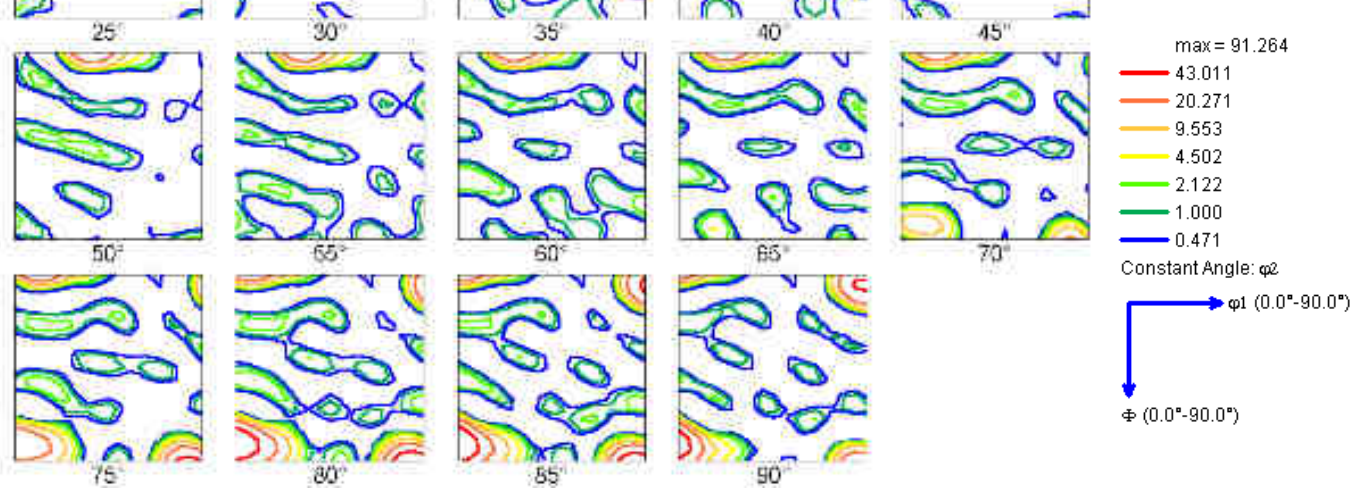

Figura 76 - FDO (EBSD) obtida para a condição de um passe. Região de retrocesso da ferramenta.

A figura 77 apresenta a distribuição dos tamanhos de grão na região de retrocesso. Existem duas populações uma com o tamanho de grão médio inferior, que está de acordo com a medição ótica, e outra de tamanho de grão médio superior, devido a existência de grãos grandes, conforme apresentado no mapa de orientação de grão, devido a localização da análise ser próxima à área da ZTMA.

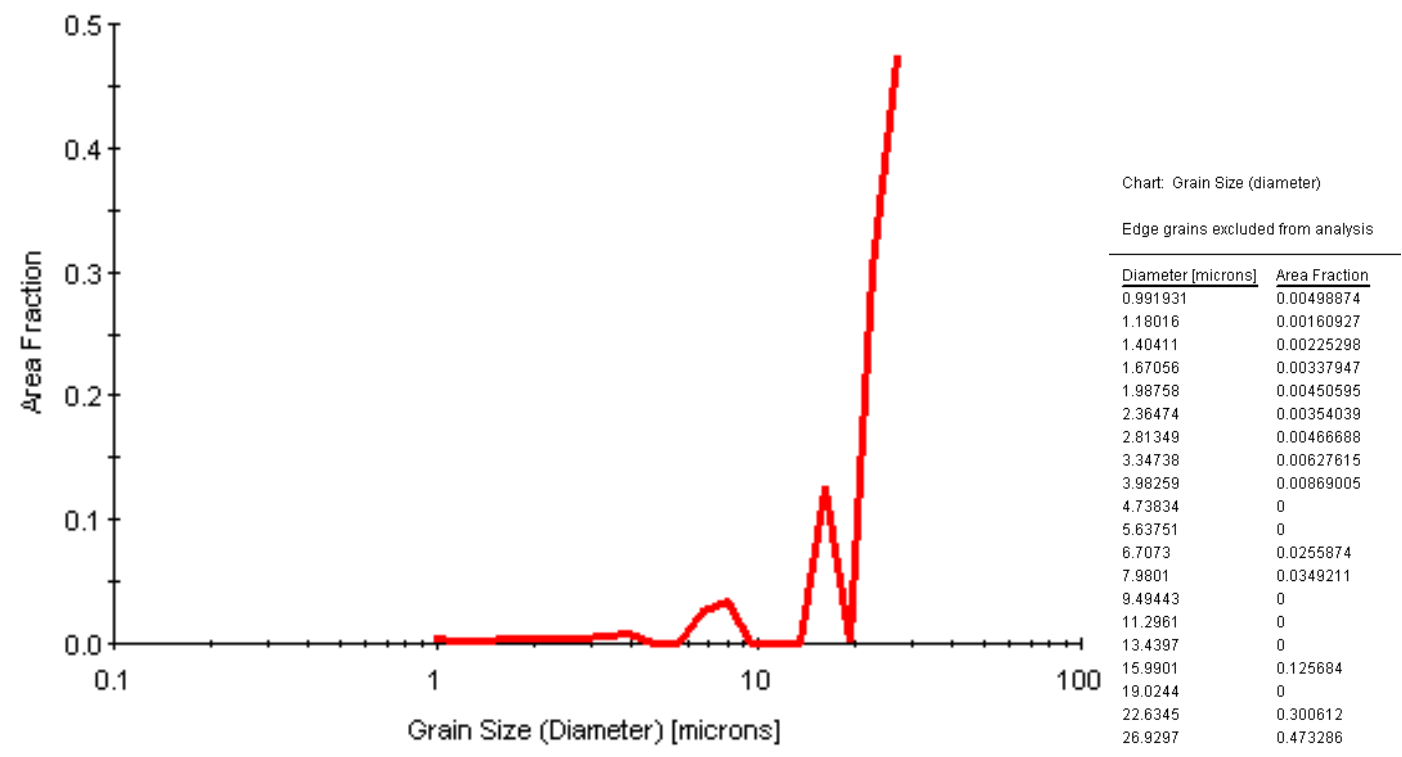

Figura 77 - Tamanho de grão para a condição de um passe. Região de retrocesso da ferramenta. 
Com base nos dados das figuras 72 e 77 foi construída a porcentagem acumulada dos tamanhos de grão do metal de base, apresentada na figura 79. Foi indicado o valor do tamanho de grão para uma porcentagem acumulada de 50\%.

O maior tamanho de grão do lado do retrocesso $(22 \mu \mathrm{m})$ pode ser devido às instabilidades para crescimento de grão, conforme foi mostrado na figura 76. Outro fator que pode ter influenciado foi a região onde foi feito o EBSD, que pode estar mais próximo da ZTMA.

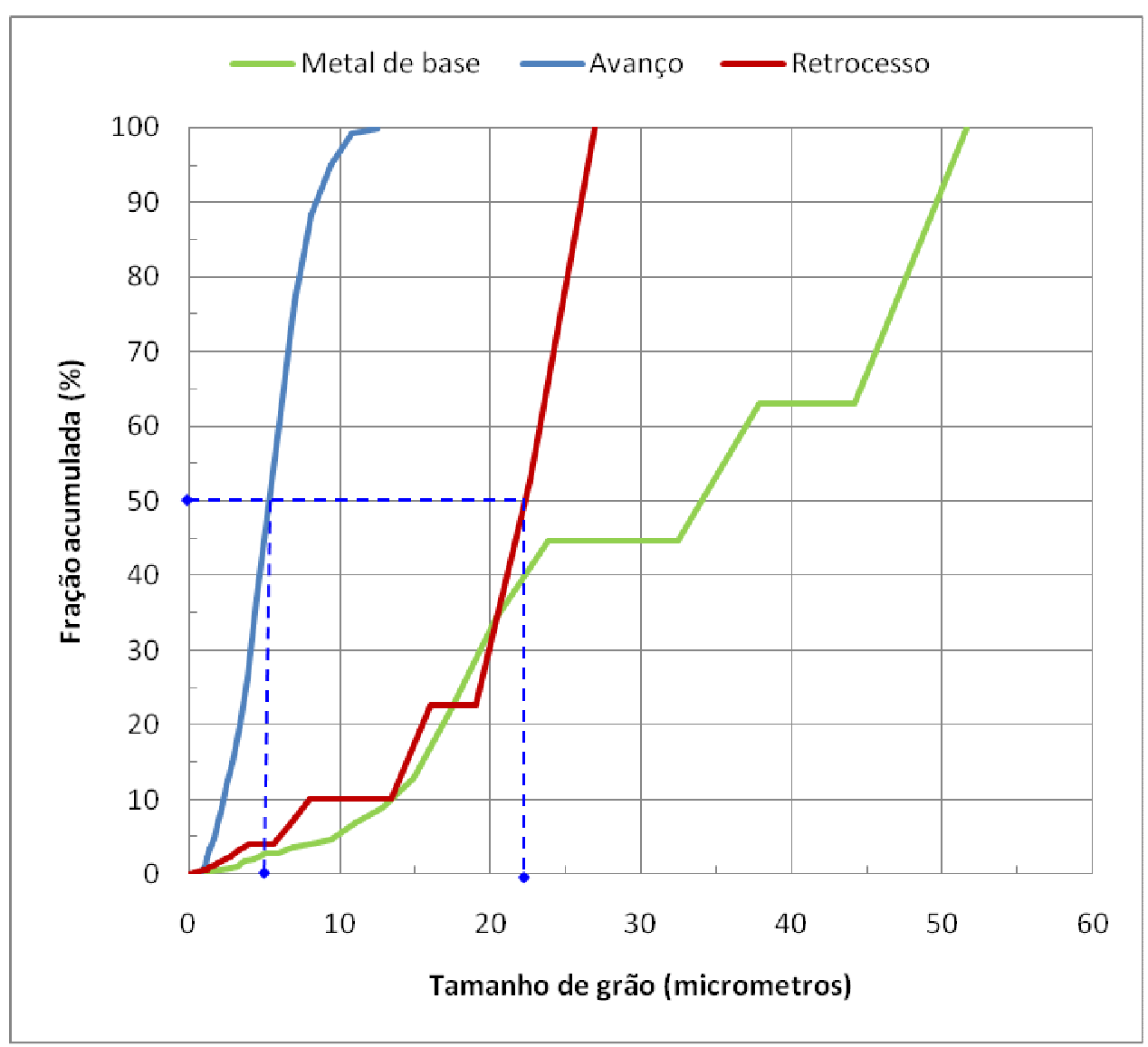

Figura 78 - Comparação entre as porcentagens acumuladas da distribuição dos tamanhos de grão obtidos por EBSD do cordão com um único passe nos lados de avanço e retrocesso e do metal de base. 


\subsubsection{Soldagem com dois passes sem reversão e sem tratamento térmico}

\subsubsection{Lado do avanço}

A figura 79 apresenta o mapa de orientação de grão para a condição de dois passes sem inversão no lado de avanço da ferramenta. São visíveis grãos finos sem uma orientação preferencial.

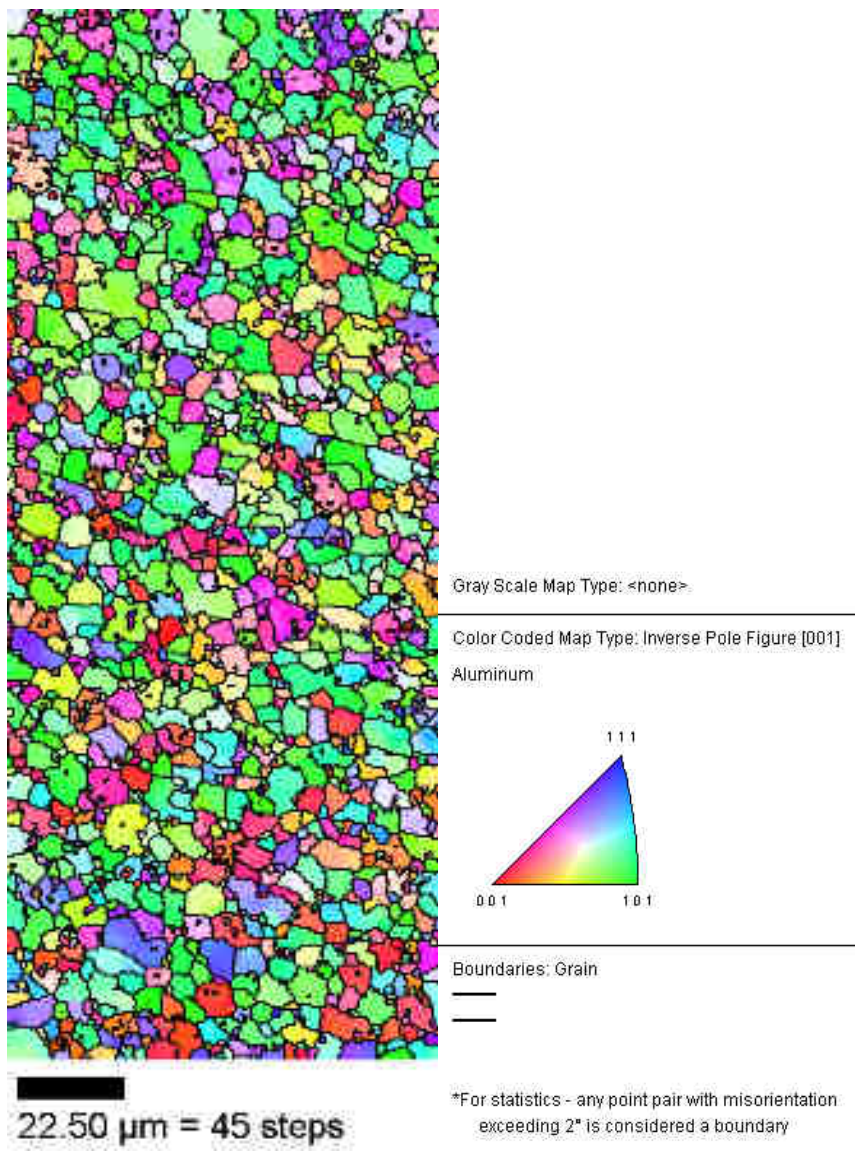

Figura 79 - Mapa de orientação de grão para a condição de dois passes. Região de avanço da ferramenta.

A figura 80 apresenta a diferença de orientação dos grãos para a região de avanço da ferramenta na condição de dois passes sem reversão da ferramenta. Esta região apresenta 10\% dos contornos de grão de baixo ângulo e o restante de alto ângulo. A 
condição de dois passes produziu um resultado similar com a de um passe, porém com uma fração de baixo ângulo inferior. Este resultado sugere que o mecanismo de recristalização predominante seja o de recristalização dinâmica.

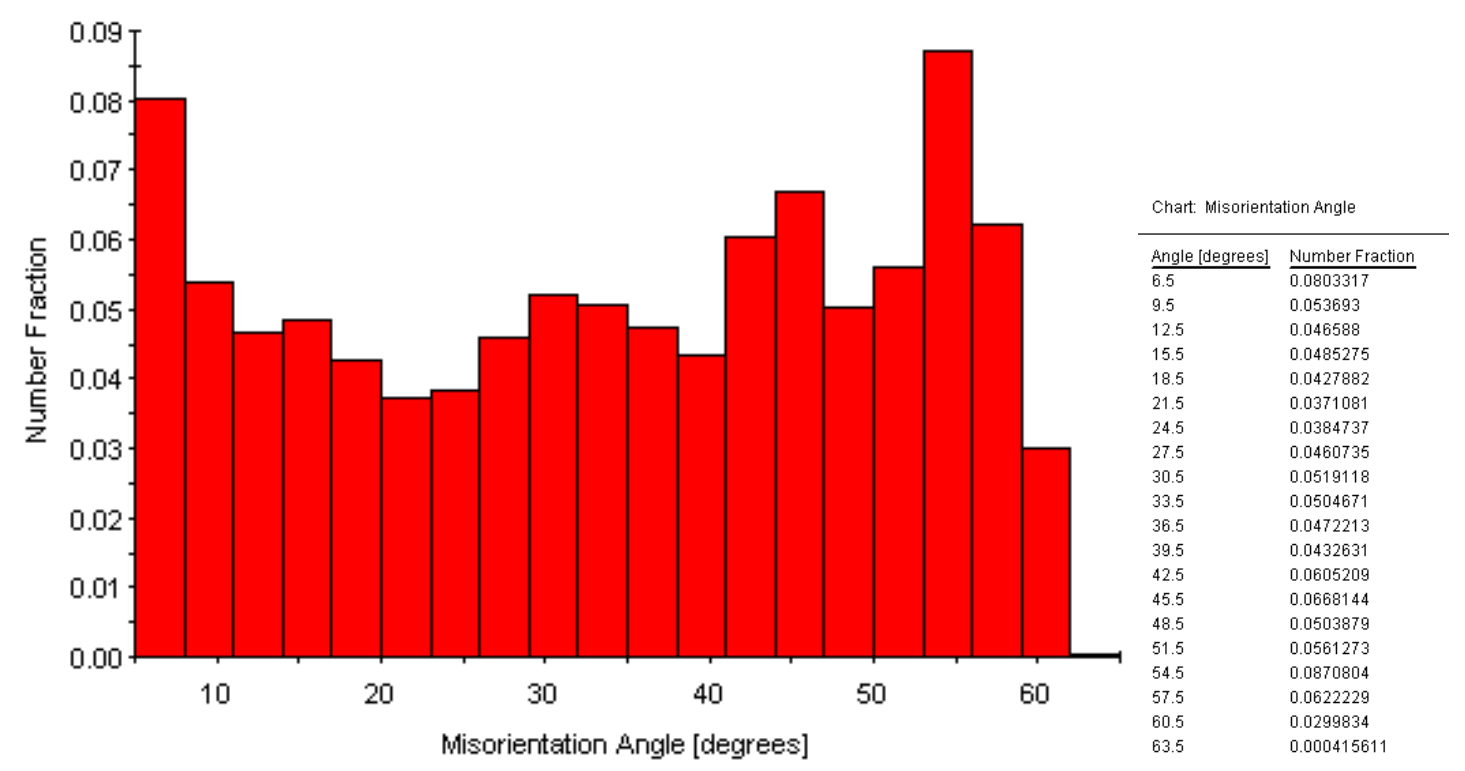

Figura 80 - Diferença de orientação dos grãos para a condição de dois passes. Região de avanço da ferramenta.

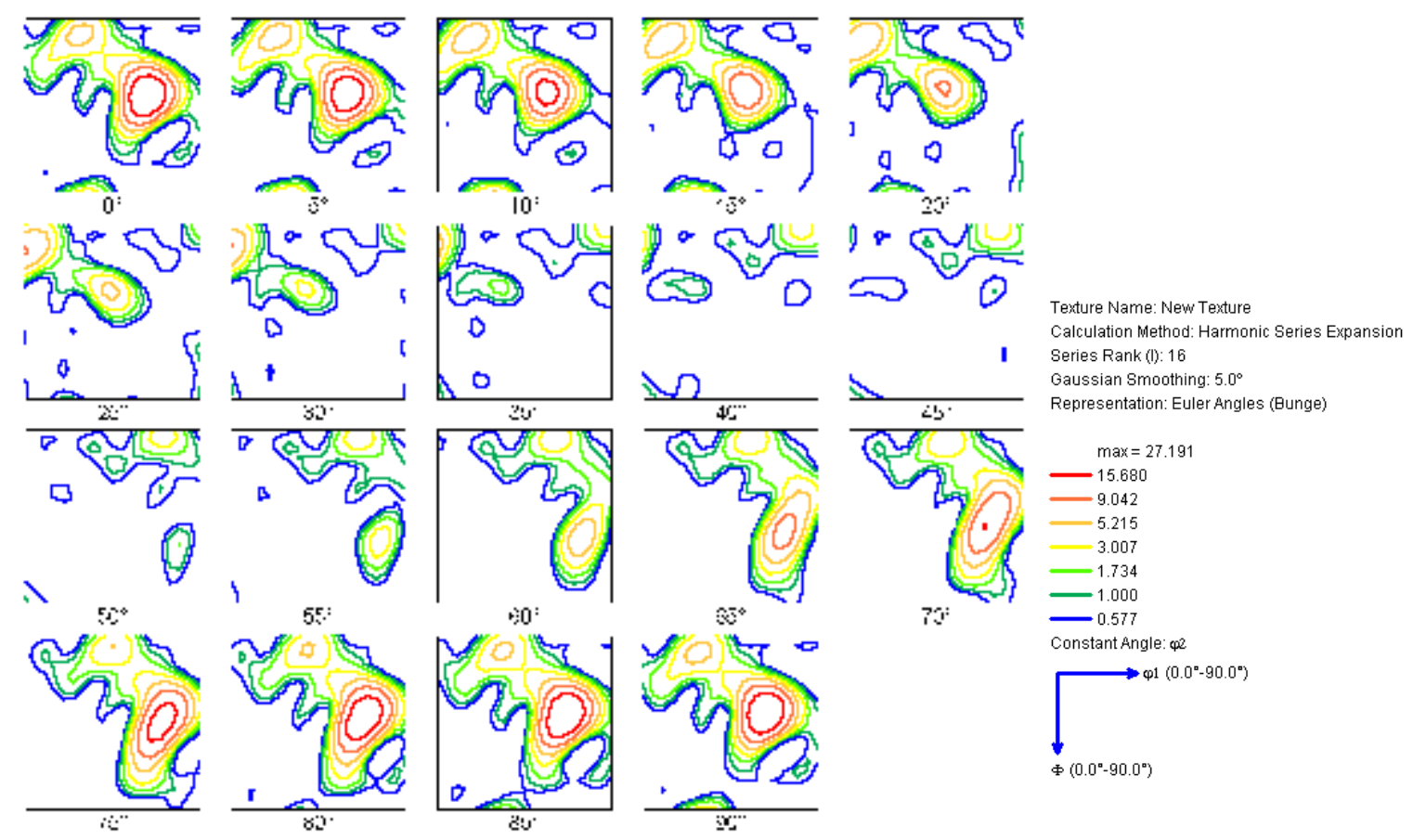

Figura 81 - FDO (EBSD) obtida para a condição de dois passes. Região de avanço da ferramenta. 
A figura 81 apresenta a função de distribuição de orientação (FDO) obtida por EBSD para dois passes na região de avanço. Os resultados obtidos não mostram nenhuma textura, como na condição de soldagem de um passe na região de avanço da ferramenta. O parâmetro máximo de 27,1 não identifica uma textura forte. 0 mesmo efeito dos fluxos de materiais em várias direções foi reforçado na condição de dois passes.

A figura 82 apresenta a distribuição dos tamanhos de grão. A medida realizada por microscopia ótica se encontra dentro dos valores obtidos por EBSD.

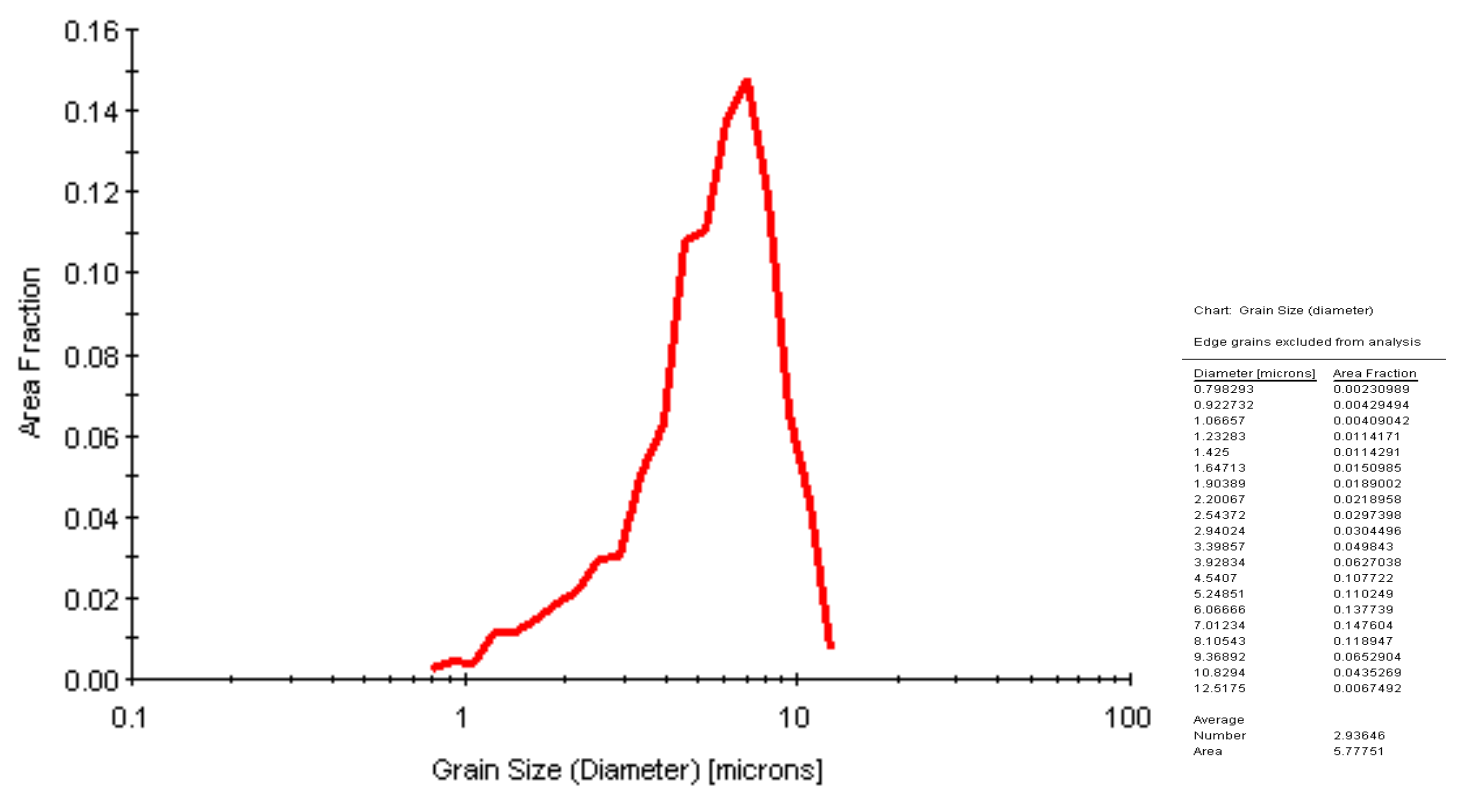

Figura 82 - Tamanho de grão para a condição de dois passes. Região de avanço da ferramenta. 


\subsubsection{Lado do retrocesso}

A figura 83 apresenta o mapa de orientação de grão para a condição de dois passes sem inversão no lado de retrocesso da ferramenta.

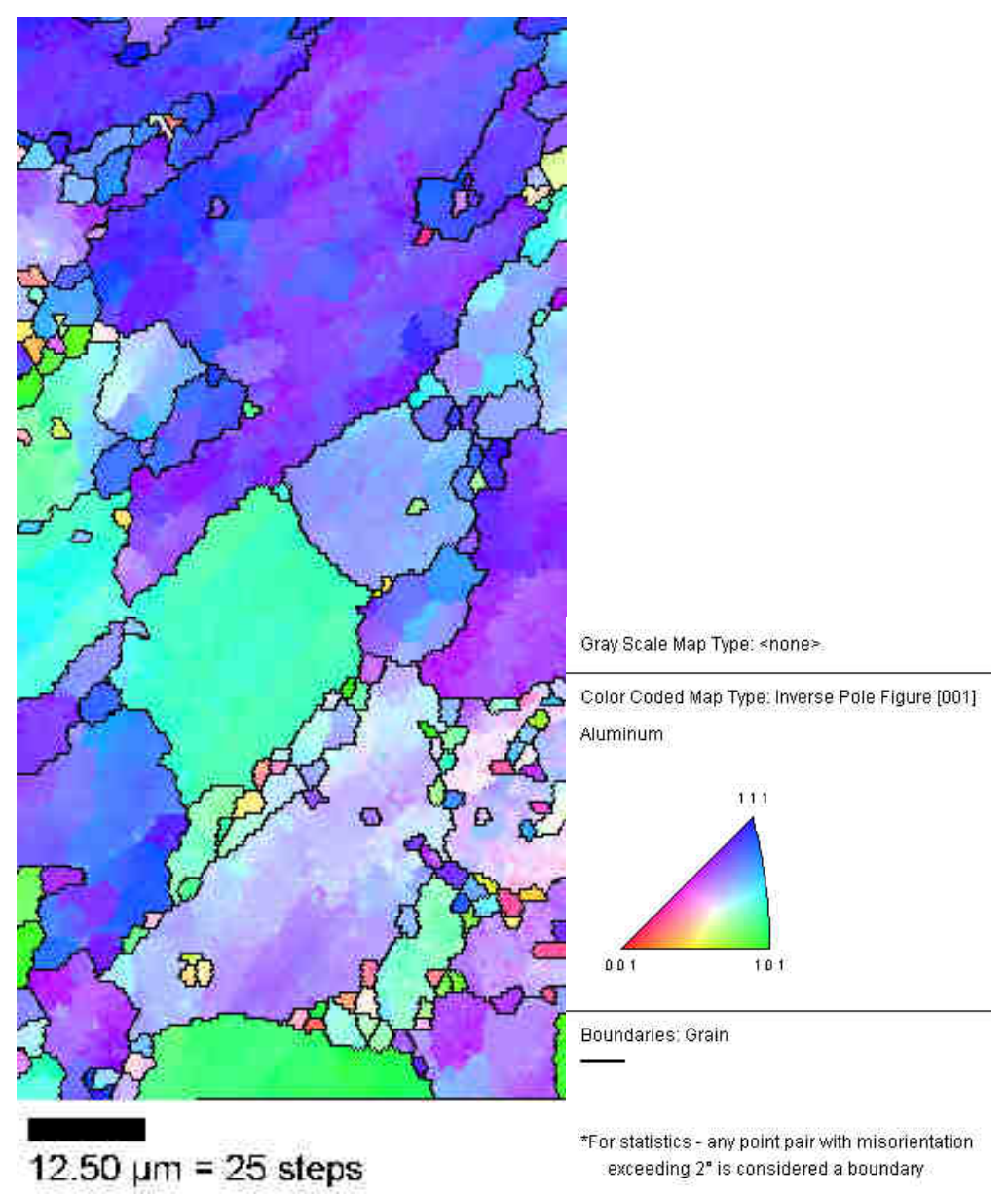

Figura 83 - Mapa de orientação de grão para a condição de dois passes. Região de retrocesso da ferramenta.

A figura 84 apresenta a diferença de orientação dos grãos para a região de retrocesso da ferramenta na condição de dois passes. A distribuição é similar a de um passe na região de retrocesso, porém com um pequeno aumento na quantidade 
de grãos de alto ângulo. Esta região apresenta $61 \%$ dos grãos com contornos de baixo ângulo.

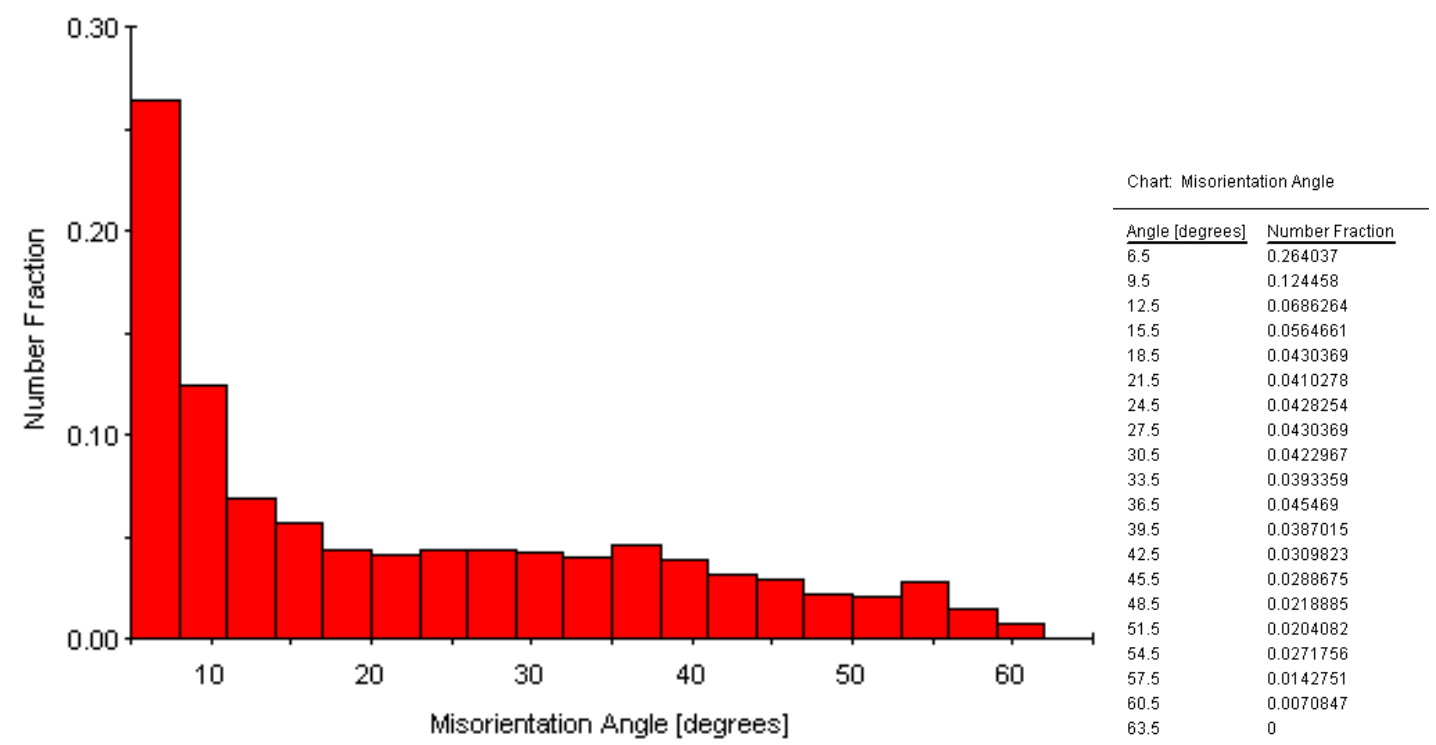

Figura 84 - Diferença de orientação dos grãos para a condição de dois passes. Região de retrocesso da ferramenta.

A título de comparação, e com base nos dados das figuras 80 e 84, foi construída a porcentagem acumulada das diferenças de orientação entre os grãos para a soldagem com um passe do lado do avanço e do retrocesso, apresentada na figura 85. Foram ressaltadas na figura as porcentagens acumuladas até uma diferença de orientação de $5^{\circ}$ e de $15^{\circ}$ e o valor médio da orientação da região para $50 \%$ da porcentagem acumulada..

Com base na figura 85 têm-se os seguintes valores:

a) Avanço:

i. Porcentagem acumulada até diferença de orientação de $5^{\circ}=5 \%$;

ii. Porcentagem acumulada até diferença de orientação de $15^{\circ}=21 \%$;

iii. Valor médio da orientação da região $=34^{\circ}$.

b) Retrocesso:

i. Porcentagem acumulada até diferença de orientação de $5^{\circ}=20 \%$; 
ii. Porcentagem acumulada até diferença de orientação de 15ำ = 50\%;

iii. Valor médio da orientação da região $=15^{\circ}$.

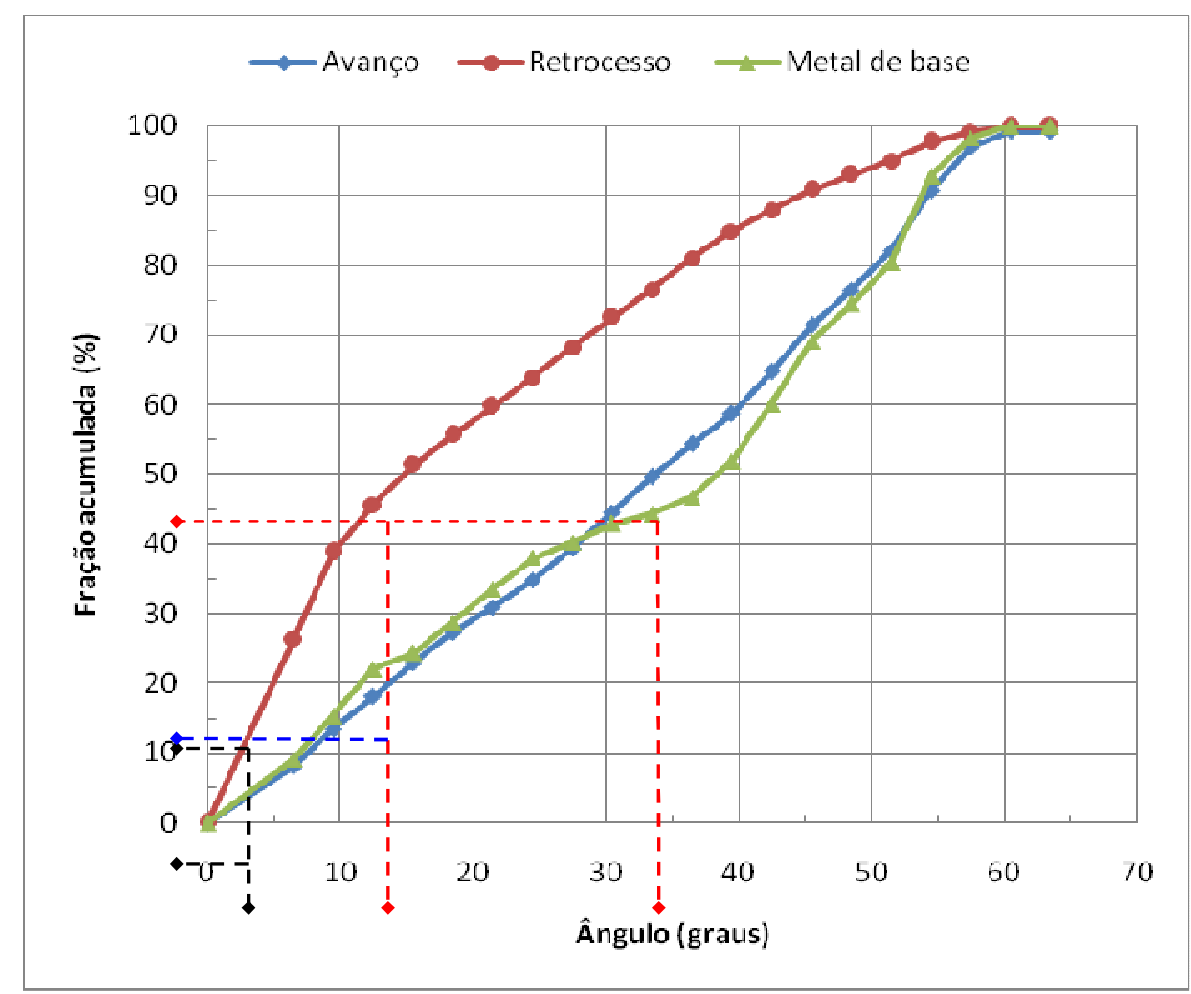

Figura 85 - Comparação entre as diferenças de orientação dos grãos do cordão de solda com dois passes sem reversão, no lado do avanço e do retrocesso, comparado com o metal de base.

Comparando-se estes resultados com os apresentados na figura 75 eles mantiveram a mesma tendência, com alterações mais significativas para o retrocesso.

A figura 86 apresenta a função de distribuição de orientação (FDO) obtida por EBSD para dois passes na região de retrocesso. Os resultados obtidos mostram componentes de textura do tipo Goss $(G),\left\{\begin{array}{ll}0 & 1\end{array}\right\}(100)$ e do tipo Cobre $(\mathrm{Cu})$, $\left\{\begin{array}{lll}1 & 1 & 2\end{array}\right\}$ (1 1 1 $)$ para $\Phi_{2}=45^{\circ}$, com parâmetro máximo de 48,5 . Estes componentes de textura são obtidos em ligas extrudadas AA $6082^{(60)}$.

Este resultado sugere que no lado de retrocesso da ferramenta, o mecanismo de conformação seja similar ao da extrusão. 


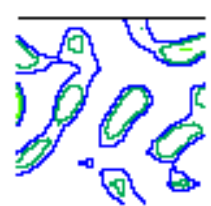

0 :
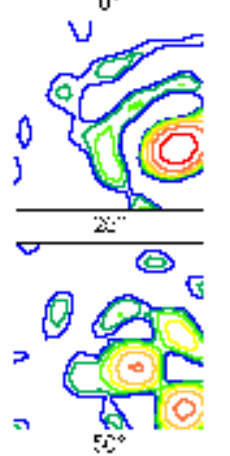

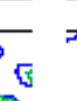
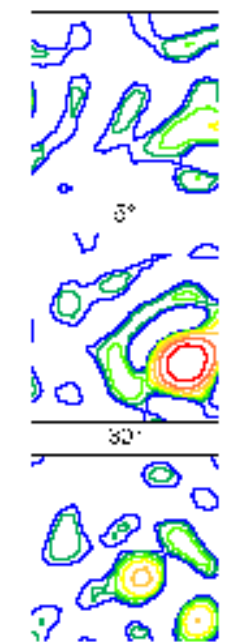

$s^{\circ}$
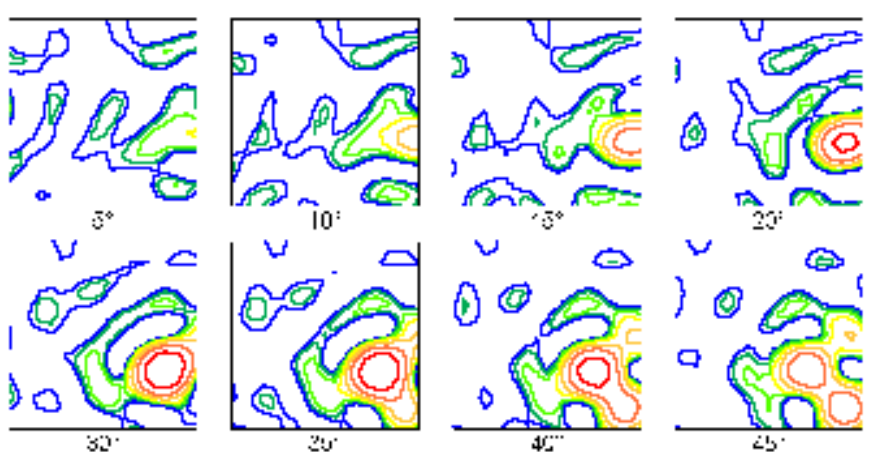

Texture Name: New Texture
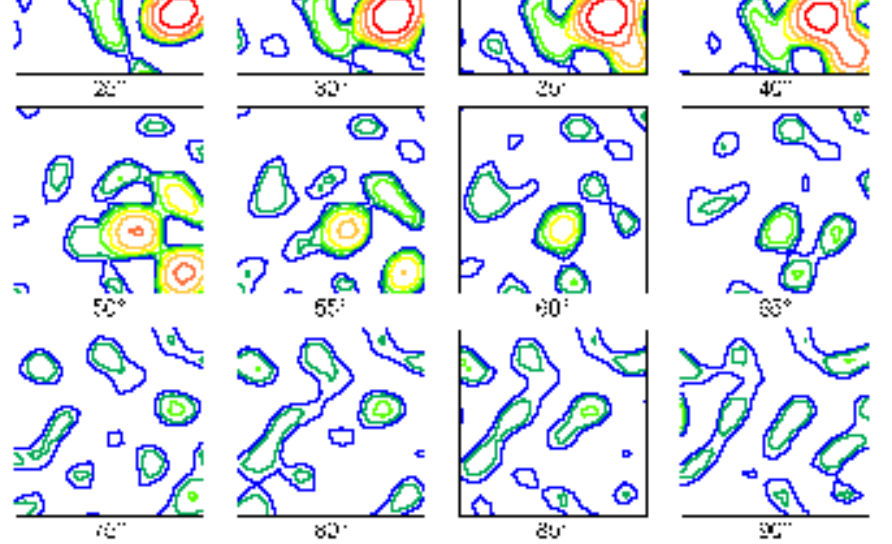

Figura 86 - FDO (EBSD) obtida para a condição de dois passes. Região de retrocesso da ferramenta.

A figura 87 apresenta a distribuição dos tamanhos de grão. Existem duas populações uma com o tamanho de grão médio inferior, que está de acordo com a medição ótica, e outra de tamanho de grão médio superior. A localização da análise está próxima á área ZTMA.

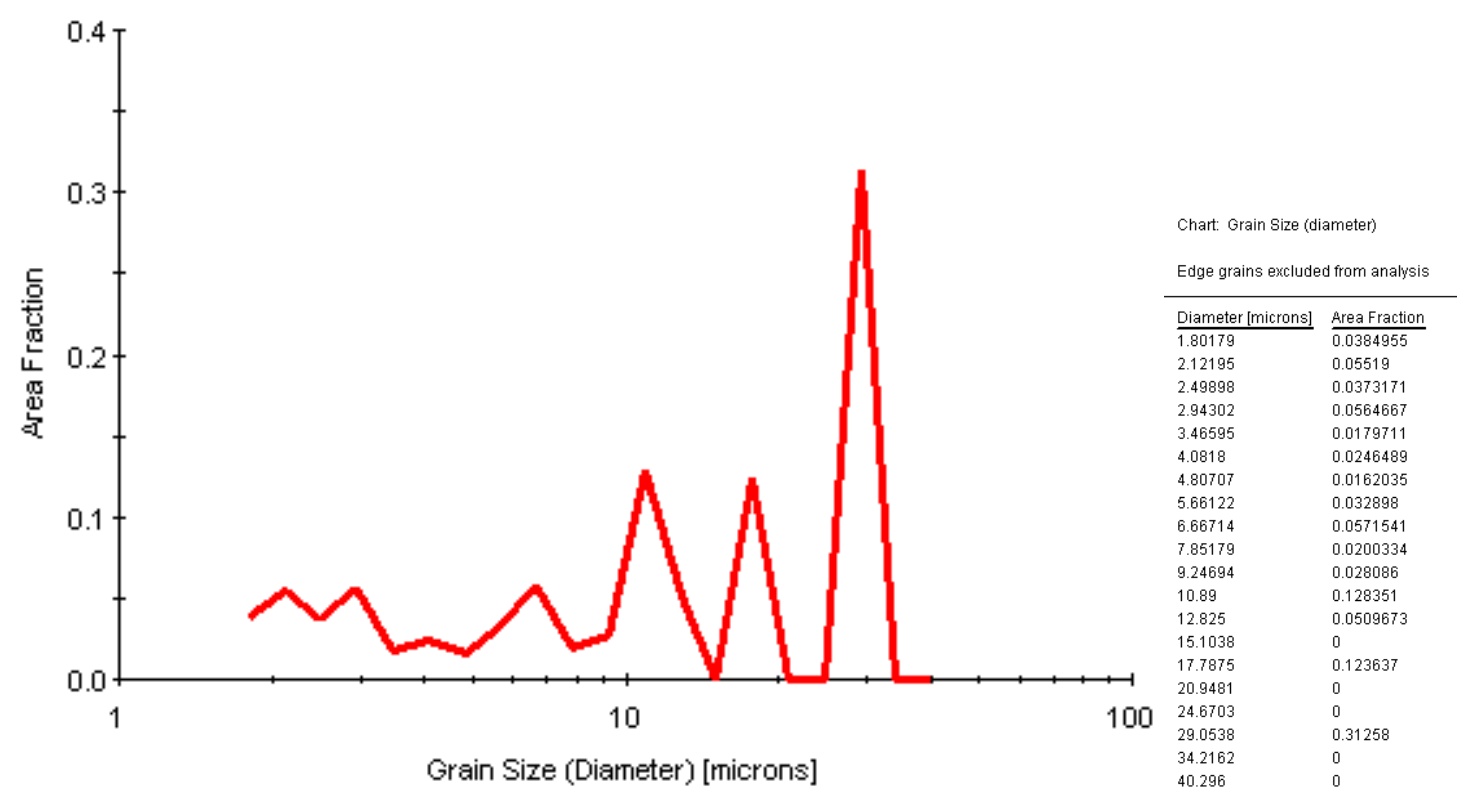

Figura 87 - Tamanho de grão para a condição de dois passes. Região de retrocesso da ferramenta. 
Com base nos dados das figuras 82 e 87 foi construída a porcentagem acumulada dos tamanhos de grão do metal de base, apresentada na figura 88. Foi indicado o valor do tamanho de grão para uma porcentagem acumulada de $50 \%$.

Comparando-se os valores obtidos na figura 78 com a figura 88 nota-se que o tamanho médio de grão para o avanço permaneceu o mesmo. Já o tamanho de grão médio do retrocesso é maior $(11 \mu \mathrm{m})$, porém menor que o tamanho obtido para um passe $(22 \mu \mathrm{m})$. Estes resultados estão de acordo com o que foi obtido nas figuras 85 e 75.

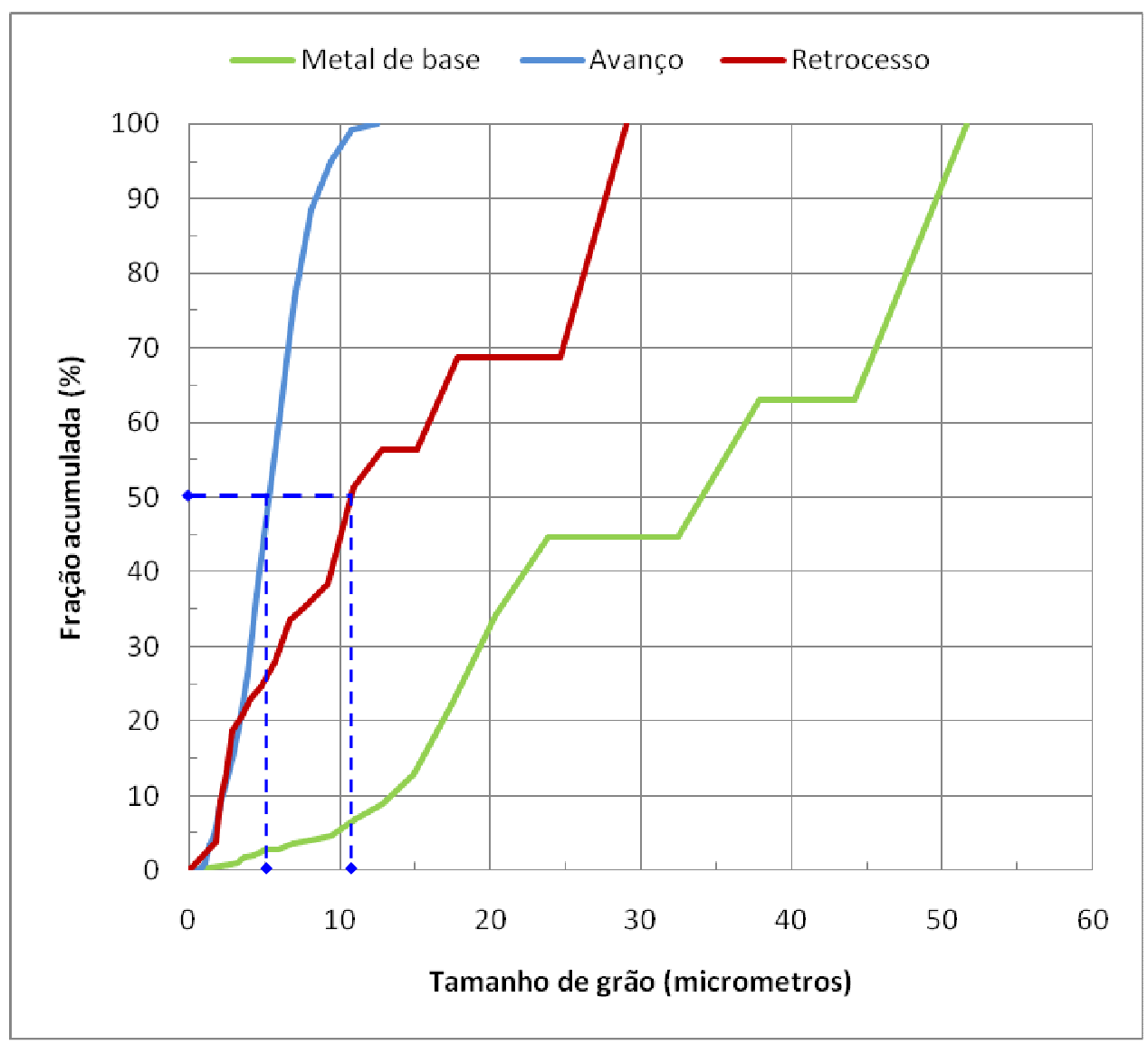

Figura 88 - Comparação entre as porcentagens acumuladas da distribuição dos tamanhos de grão obtidos por EBSD do cordão com dois passes sem reversão nos lados de avanço e retrocesso e do metal de base. 


\subsubsection{Soldagem com dois passes com reversão e sem tratamento térmico}

\subsubsection{Lado do avanço}

A figura 89 apresenta o mapa de orientações para a condição de soldagem de dois passes com inversão, no lado de avanço da ferramenta.

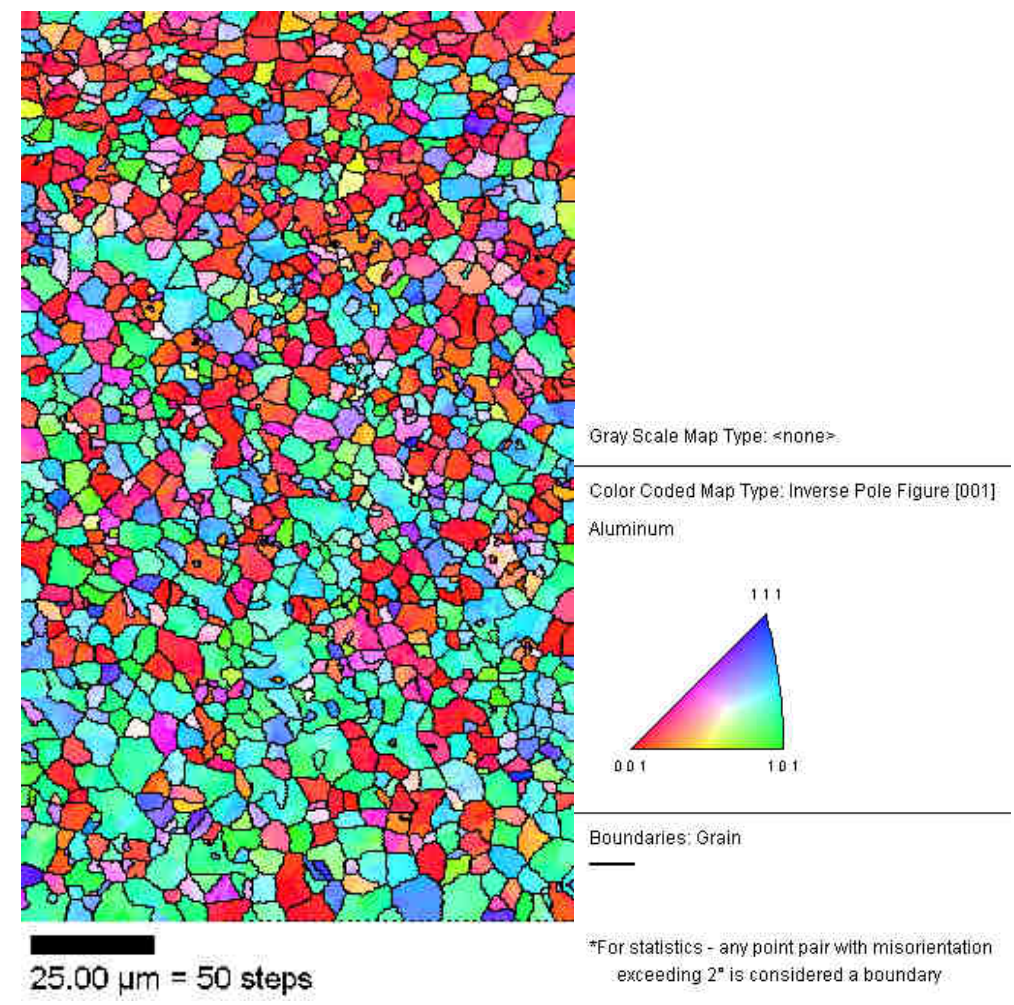

Figura 89 - Mapa de orientação de grão para a condição de dois passes com inversão. Região de avanço da ferramenta.

A figura 90 apresenta a diferença de orientação dos grãos para a região de avanço da ferramenta na condição de dois passes com inversão. Esta região apresenta $36 \%$ dos contornos de grão de baixo ângulo e o restante de alto ângulo. A condição de dois passes com inversão produziu uma distribuição mista entre o lado de avanço e retrocesso da condição de um passe ou dois passes sem inversão. Este resultado 
sugere que a distribuição da orientação dos grãos está relacionada com o sentido de giro da ferramenta e sua translação.

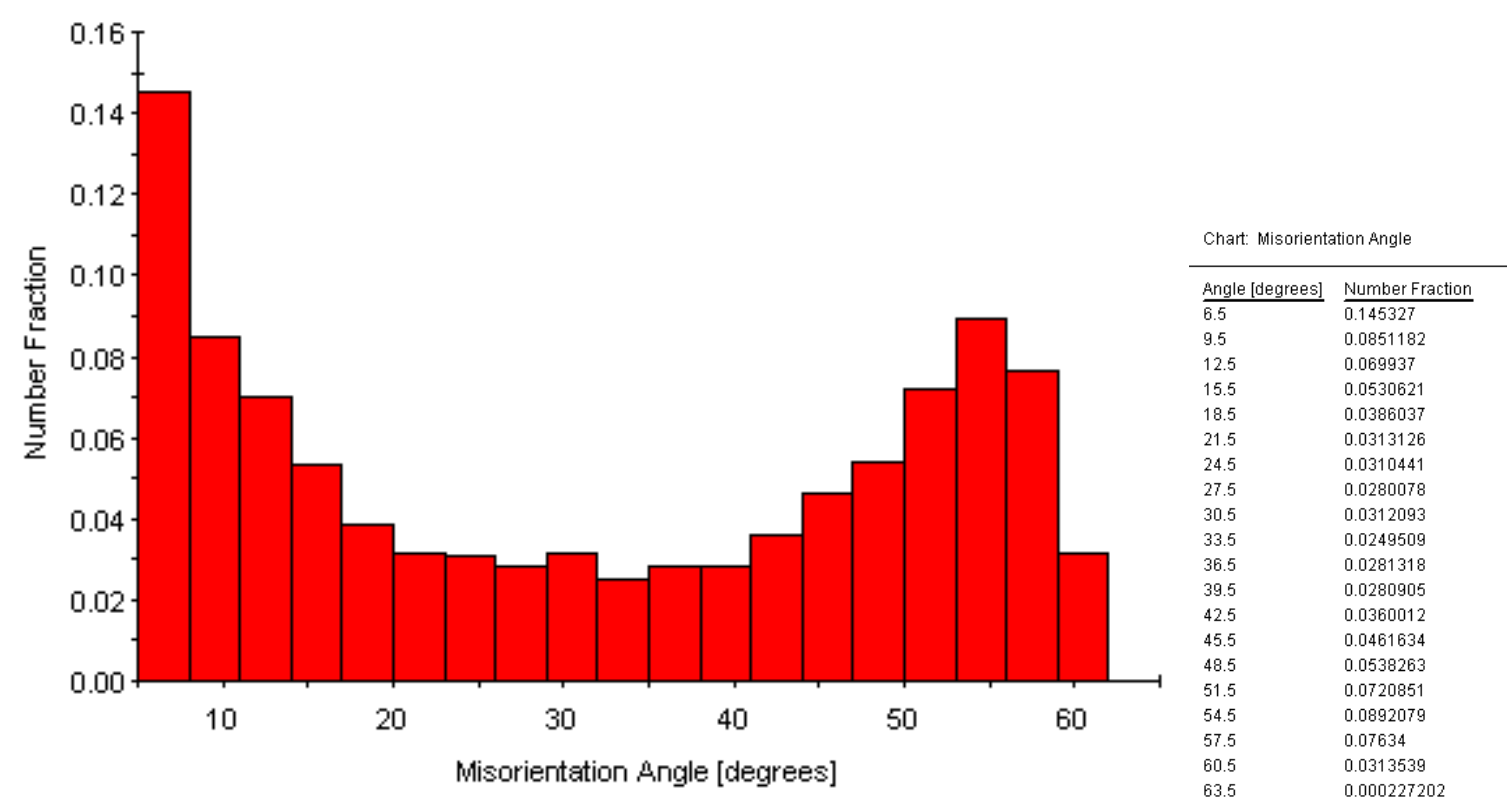

Figura 90 - Diferença de orientação dos grãos para a condição de dois passes com inversão. Região de avanço da ferramenta.
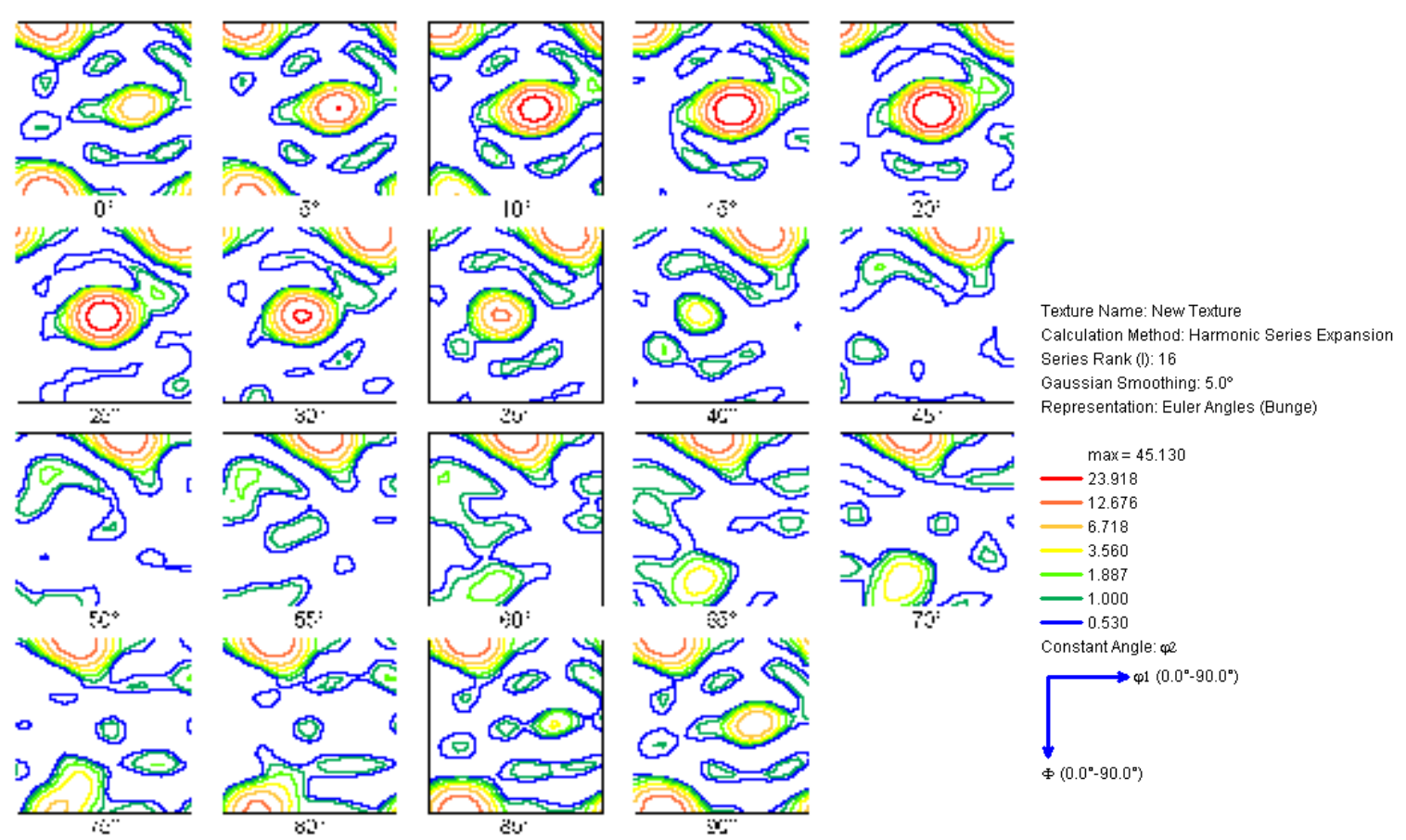

Figura 91 - FDO (EBSD) obtida para a condição de dois passes com inversão. Região de avanço da ferramenta. 
A figura 91 apresenta a função de distribuição de orientação (FDO) obtida por EBSD para dois passes com inversão na região de avanço. Os resultados mostram uma componente de textura do tipo Cubo (C), $\left\{\begin{array}{llll}1 & 0 & 0\end{array}\right\}\left\{\begin{array}{lll}0 & 0 & 1\end{array}\right)$ em $\Phi_{2}=45^{\circ}$, com parâmetro máximo de 45,1. O lado de avanço da condição de soldagem anterior não apresentava componentes de textura no local analisado. Esta componente deve estar relacionada com a componente existente nesta região de tipo Cubo (C) $\left\{\begin{array}{lll}1 & 0 & 0\end{array}\right\}\left\langle\begin{array}{lll}0 & 0 & 1\end{array}\right)$ para $\Phi_{2}=45^{\circ}$, proveniente do primeiro passe da soldagem.

A figura 92 apresenta a distribuição dos tamanhos de grão. Esta distribuição está de acordo com as medições óticas realizadas previamente.

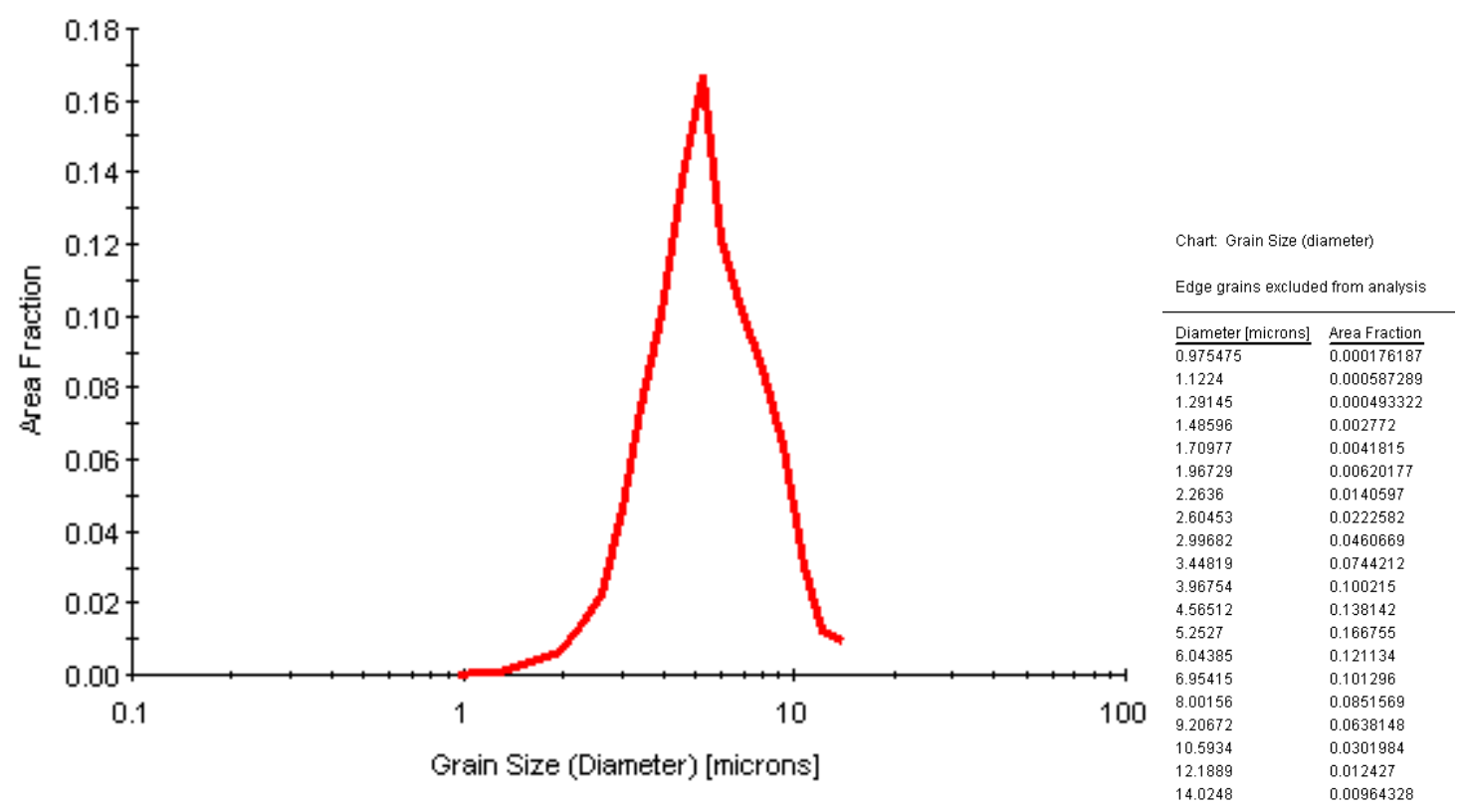

Figura 92 - Tamanho de grão para a condição de dois passes com inversão. Região de avanço da ferramenta.

\subsubsection{Lado do retrocesso}

A figura 93 apresenta o mapa de orientação de grão para a condição de dois passes com inversão no lado de retrocesso da ferramenta. São visíveis grãos finos e uma orientação preferencial. 


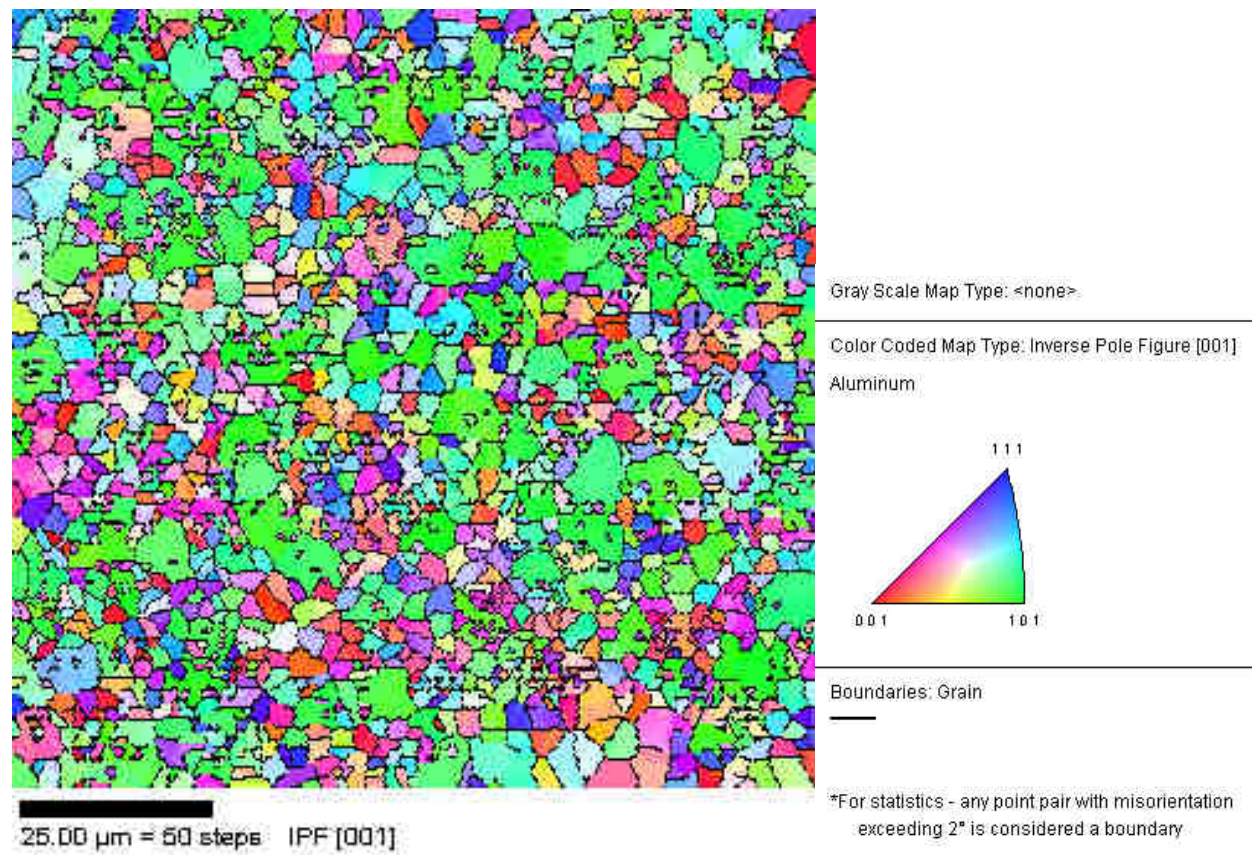

Figura 93 - Mapa de orientação de grão para a condição de dois passes com inversão. Região de retrocesso da ferramenta.

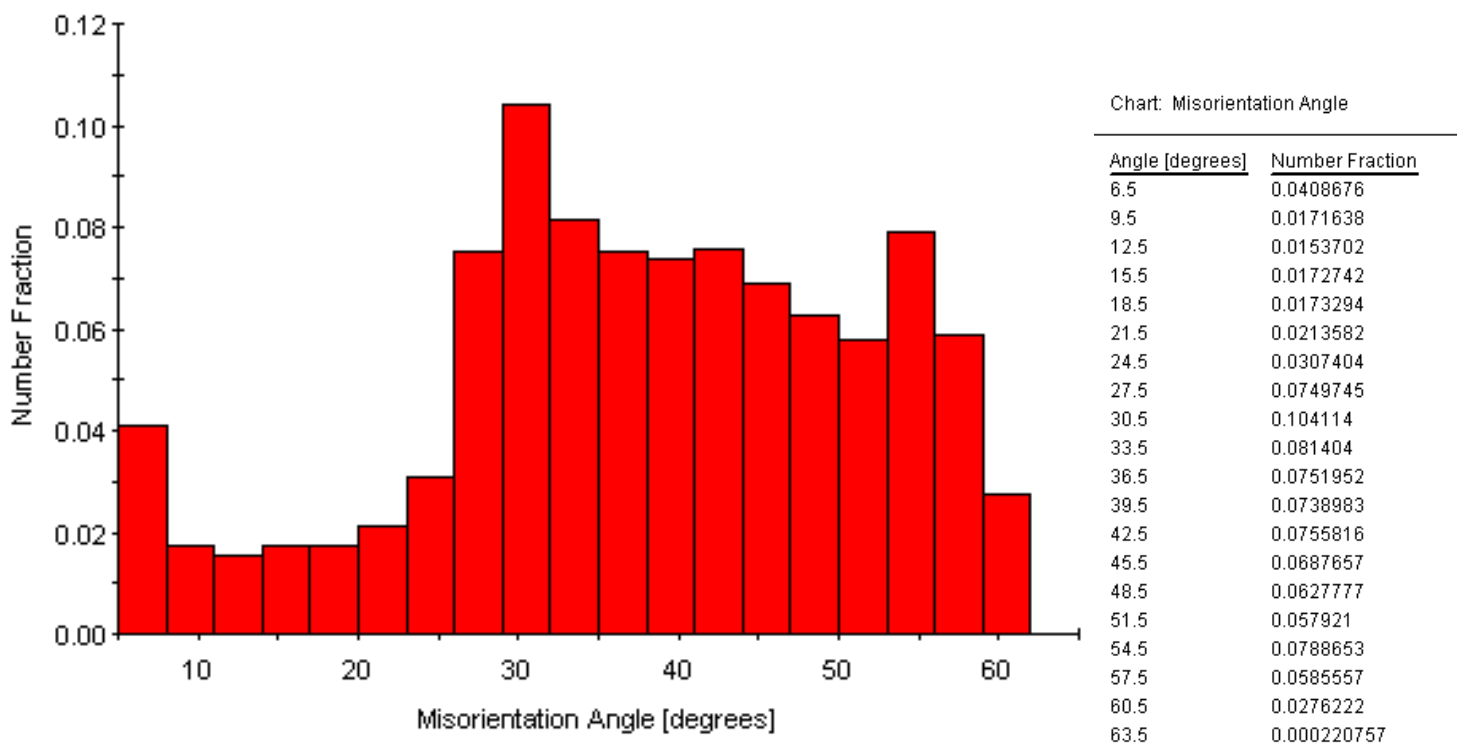

Figura 94 - Diferença de orientação dos grãos para a condição de dois passes com inversão. Região de retrocesso da ferramenta.

A figura 94 apresenta a diferença de orientação dos grãos para a região de retrocesso da ferramenta na condição de dois passes com inversão. Esta região apresenta $8 \%$ dos contornos de grão de baixo ângulo e o restante de alto ângulo. A condição de dois passes com inversão, no lado de retrocesso, também produziu 
uma distribuição mista entre o lado de avanço e retrocesso da condição de um passe ou dois passes sem inversão.

A título de comparação, e com base nos dados das figuras 90 e 94, foi construída a porcentagem acumulada das diferenças de orientação entre os grãos para a soldagem com um passe do lado do avanço e do retrocesso, apresentada na figura 95. Foram ressaltadas na figura as porcentagens acumuladas até uma diferença de orientação de $5^{\circ}$ e de $15^{\circ}$ e o valor médio da orientação da região para $50 \%$ da porcentagem acumulada.

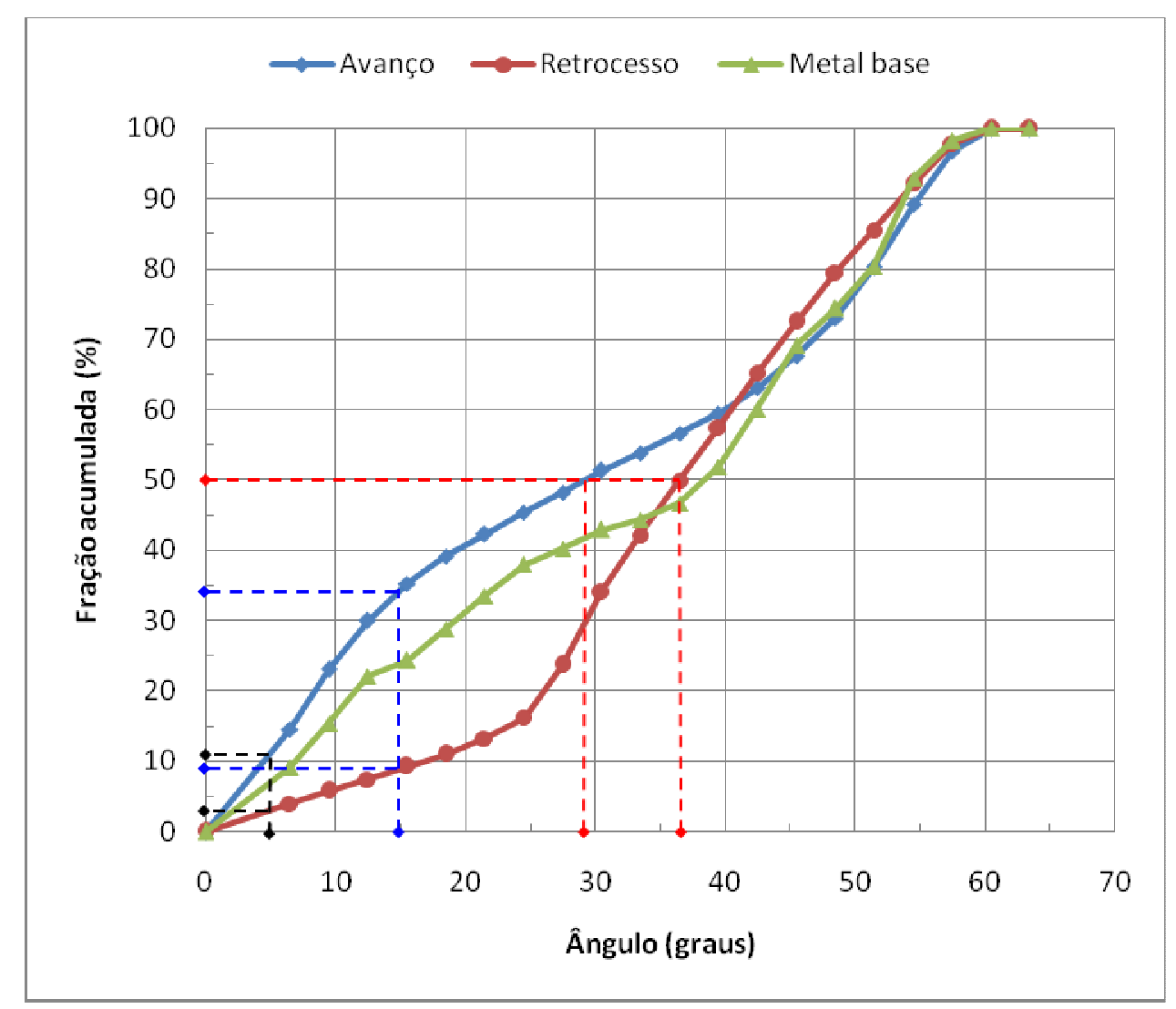

Figura 95 - Comparação entre as diferenças de orientação dos grãos do cordão de solda com dois passes com reversão, no lado do avanço e do retrocesso, comparado com o metal de base.

Com base na figura 95 têm-se os seguintes valores:

a) Avanço: 
i. Porcentagem acumulada até diferença de orientação de $5^{0}=10 \%$;

ii. Porcentagem acumulada até diferença de orientação de 15으 = 34\%;

iii. Valor médio da orientação da região $=29^{\circ}$.

b) Retrocesso:

i. Porcentagem acumulada até diferença de orientação de 5으 = 3\%;

ii. Porcentagem acumulada até diferença de orientação de $15^{\circ}=9 \%$;

iii. Valor médio da orientação da região $=37^{\circ}$.

Comparando-se estes resultados com os apresentados nas figuras 75 e 85 nota-se que os resultados do avanço praticamente mantiveram a mesma tendência. Já o retrocesso apresentou valores comparáveis com avanço.
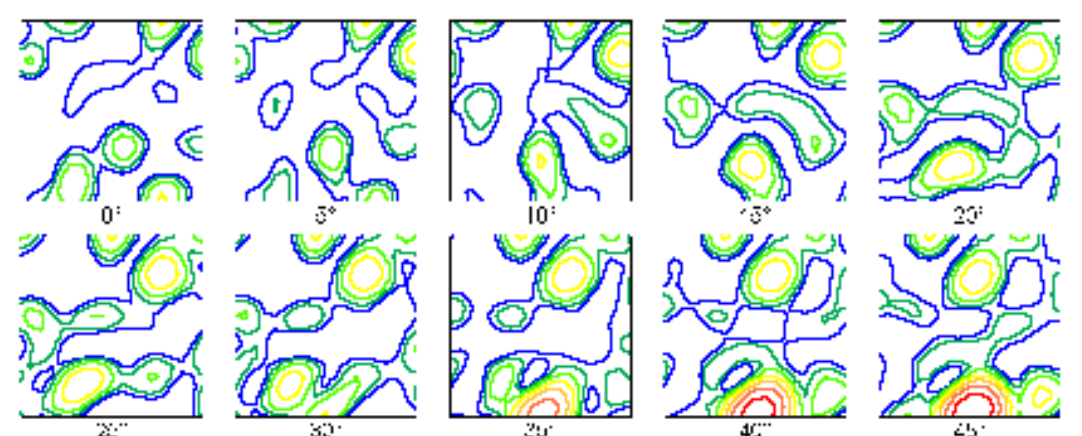

Texture Name: New Texture

Calculation Method: Harmonic Series Expansion

Series Rank (1): 16

Gaussian Smoothing: $5.0^{\circ}$

Representation: Euler Angles (Bunge)
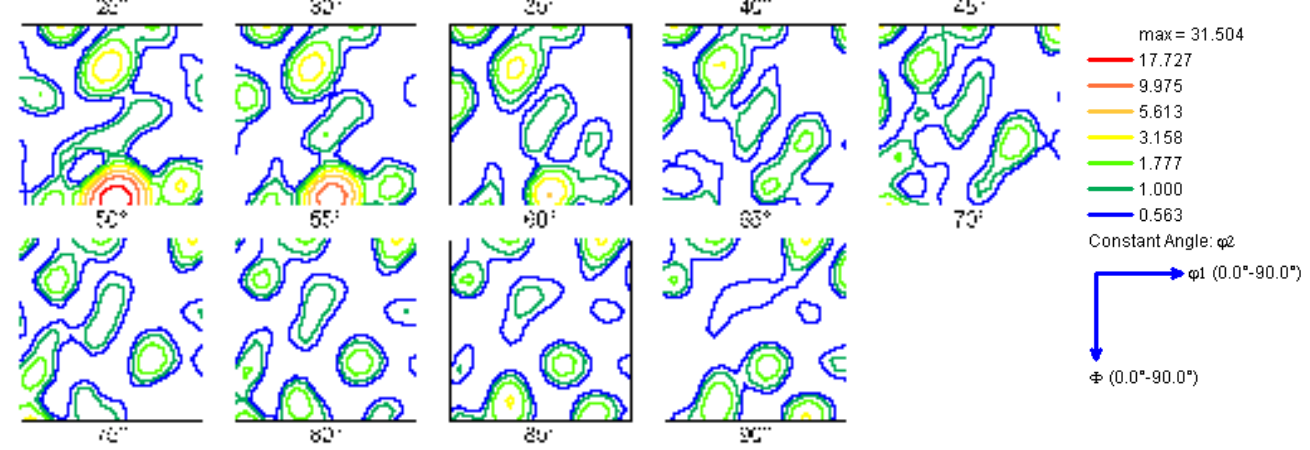

Figura 96 - FDO (EBSD) obtida para a condição de dois passes com inversão. Região de retrocesso da ferramenta.

A figura 96 apresenta a função de distribuição de orientação (FDO) obtida por EBSD para dois passes com inversão na região de retrocesso. Os resultados mostram uma componente de textura do tipo Latão, $\left\{\begin{array}{llll}1 & 1 & 0\end{array}\right\}\left(\begin{array}{lll}1 & 1 & 2\end{array}\right)$ em $\Phi_{2}=45^{\circ}$, com parâmetro 
máximo de 31,5 . Esta textura se originou com a deformação de uma região do cordão que não apresentava textura anteriormente, porém o lado de retrocesso da ferramenta adiciona uma componente de textura.

A figura 97 apresenta a distribuição dos tamanhos de grão. Existem duas populações uma com o tamanho de grão médio inferior, e outra superior, que está de acordo com a medição ótica. A estatística desta medida leva em consideração contornos superiores a $2^{\circ}$ que podem não ser distinguíveis por microscopia óptica.

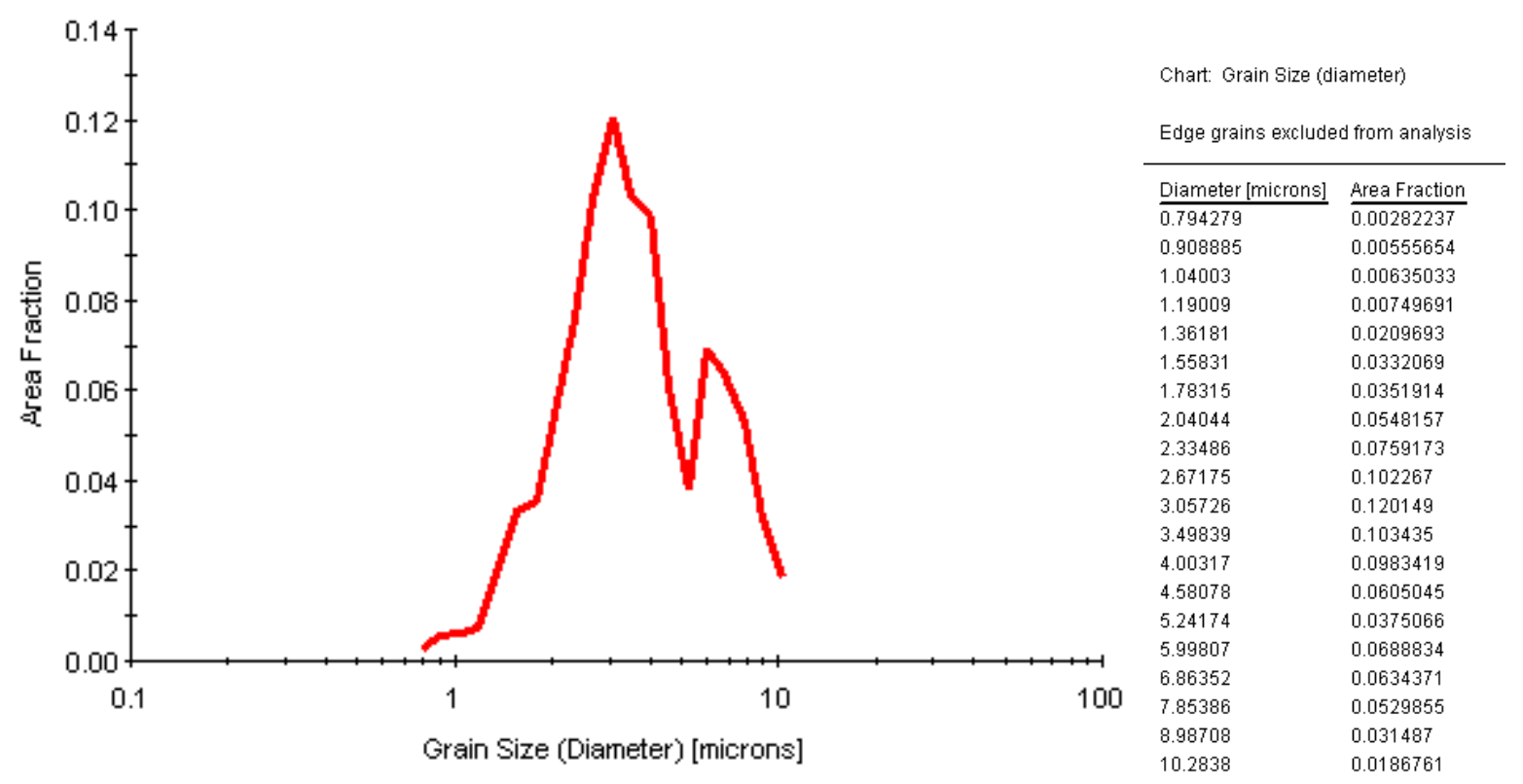

Figura 97 - Tamanho de Grão para a condição de dois passes com inversão. Região de retrocesso da ferramenta.

Com base nos dados das figuras 92 e 97 foi construída a porcentagem acumulada dos tamanhos de grão do metal de base, apresentada na figura 98. Foi indicado o valor do tamanho de grão para uma porcentagem acumulada de $50 \%$.

Comparando-se os valores obtidos nas figuras 79 e 89 nota-se que o tamanho médio de grão para o avanço permaneceu o mesmo. Já o tamanho de grão médio do retrocesso é bem menor $(3 \mu \mathrm{m})$ do que os resultados anteriores $(22 \mu \mathrm{m}$ para um passe e $12 \mu \mathrm{m}$ para dois cordões sem reversão). 


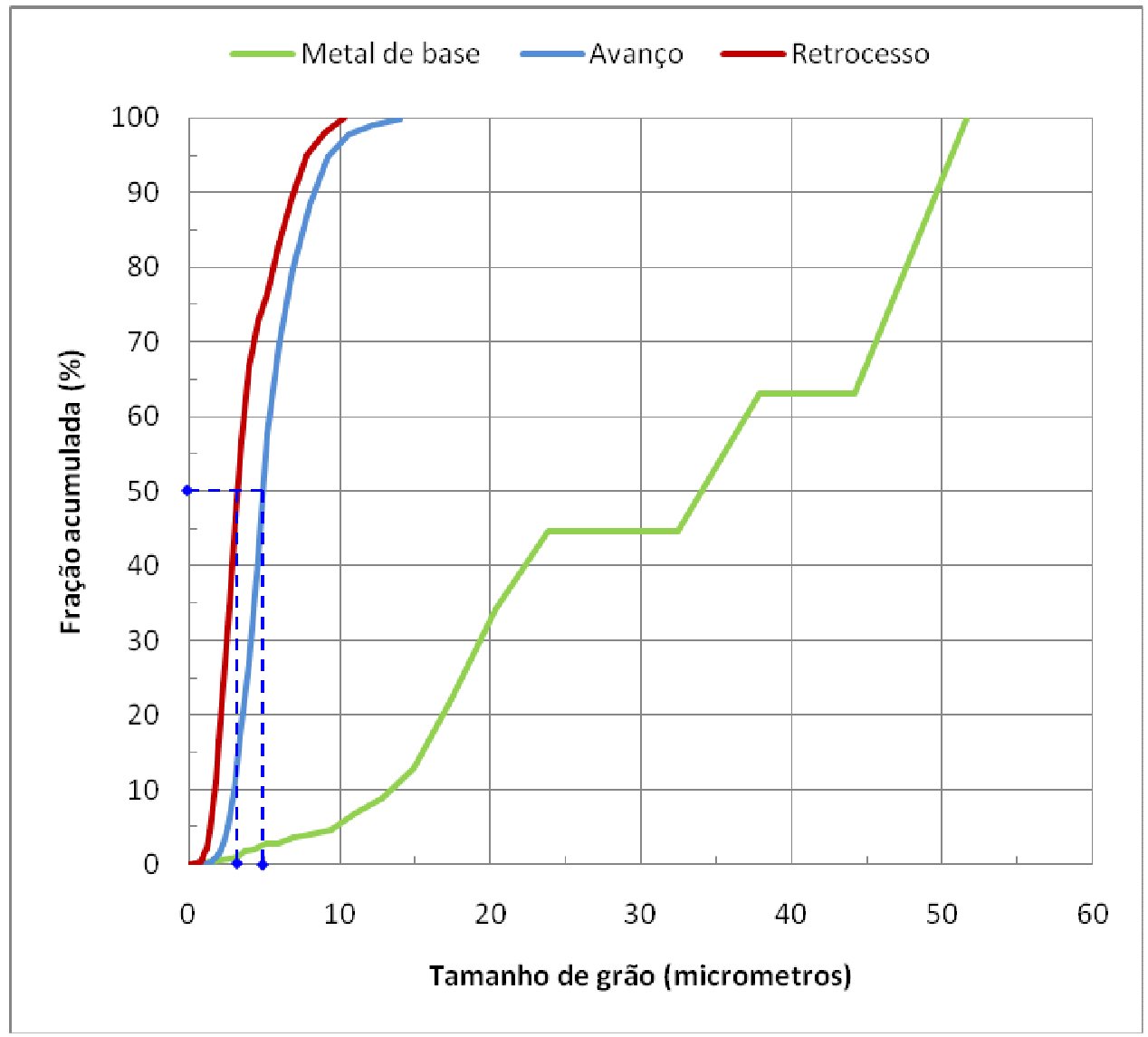

Figura 98 - Comparação entre as porcentagens acumuladas da distribuição dos tamanhos de grão obtidos por EBSD do cordão com dois passes com reversão nos lados de avanço e retrocesso e do metal de base.

\subsubsection{Soldagem com dois passes sem reversão e com tratamento térmico}

As figuras 99 e 100 apresentam a função de distribuição de orientação (FDO) obtida por EBSD para 2 passes com tratamento térmico na região de avanço e retrocesso, respectivamente.

Os resultados obtidos mostram que a região de avanço anteriormente sem componente de textura, desenvolveu uma textura típica de recristalização para ligas de alumínio do tipo Cubo (C) $\left[\begin{array}{llll}1 & 0 & 0\end{array}\right\}\left(\begin{array}{lll}0 & 0 & 1\end{array}\right)$, para $\Phi_{2}=45^{\circ}$, com parâmetro máximo de 36,8. Já a região de retrocesso perdeu a sua componente de textura no tratamento de recozimento. 
A redução ou eliminação da componente de textura com tratamentos térmicos é prevista e pode estar relacionada com a textura pré existente no metal de base.

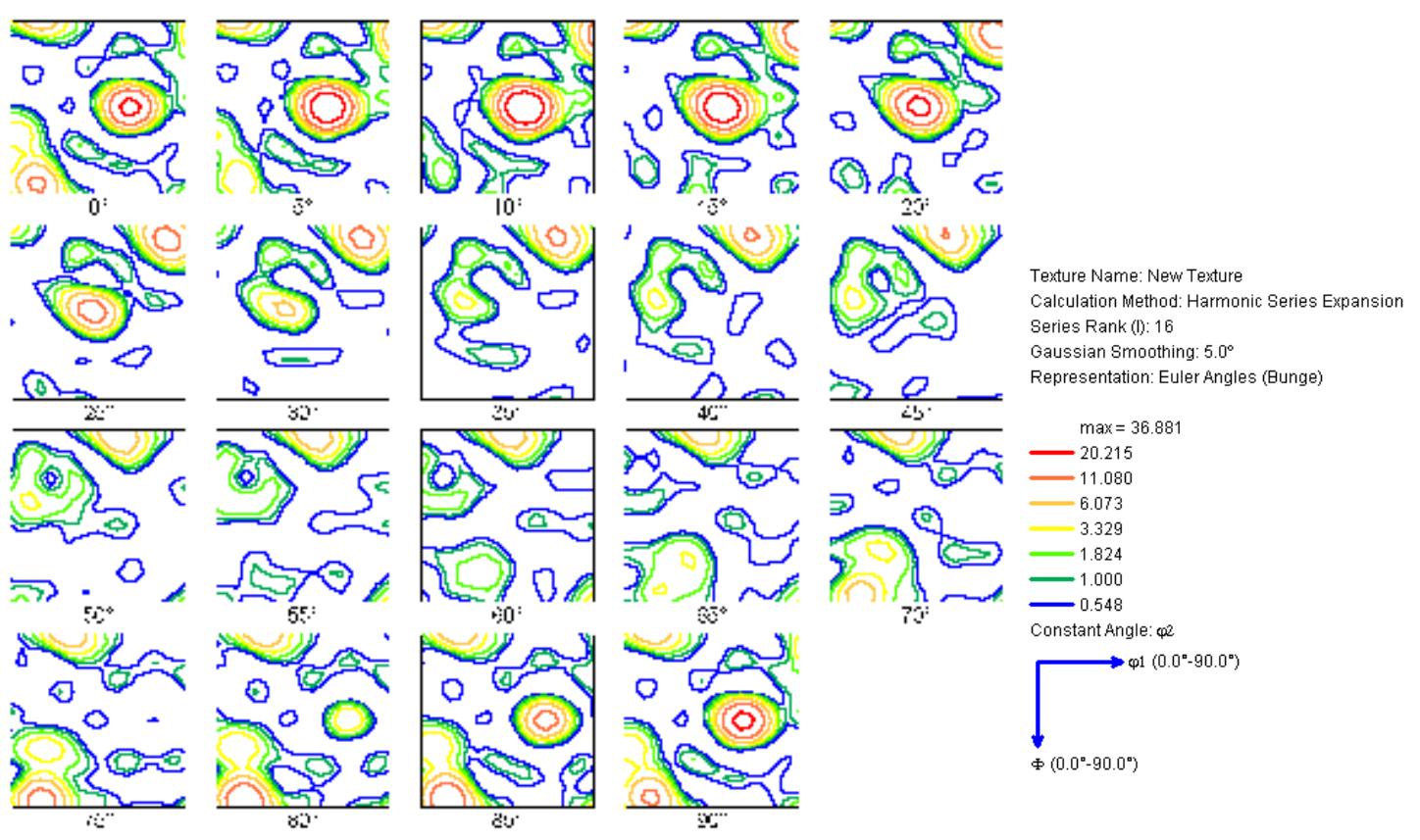

Figura 99 - Diferença de orientação dos grãos para a condição de dois passes com tratamento térmico de recozimento por 8 horas. Região de avanço da ferramenta.
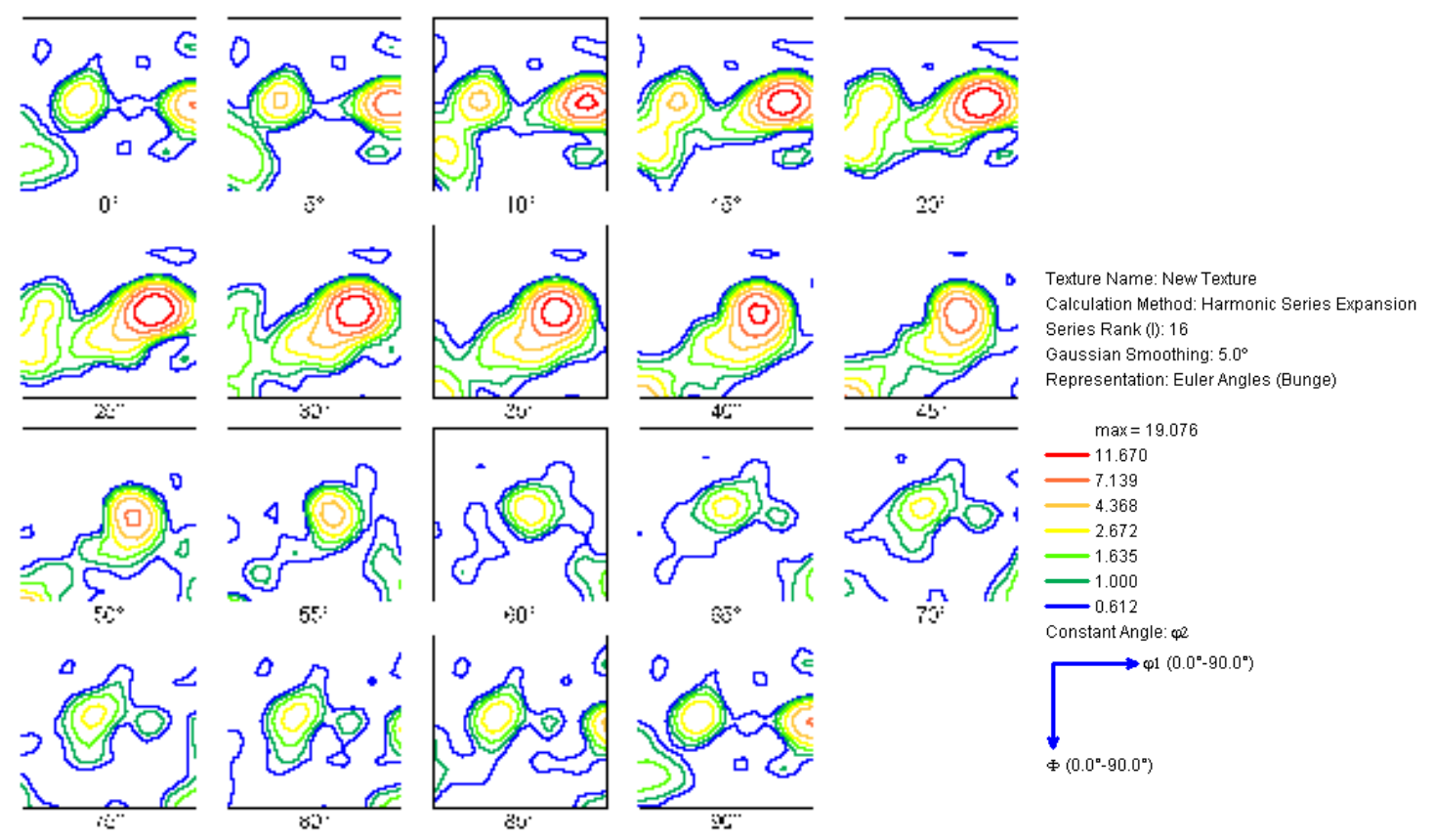

Figura 100 - Diferença de orientação dos grãos para a condição de dois passes com tratamento térmico de recozimento por 8 horas. Região de retrocesso da ferramenta. 
Os tamanhos de grão das regiões do cordão de dois passes recozido ficaram dentro dos valores da microscopia ótica e estão apresentados na figura 101.

a)

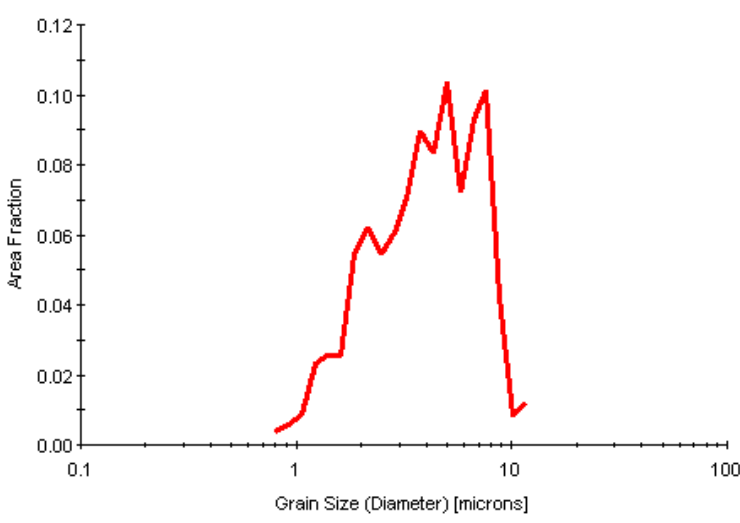

b)

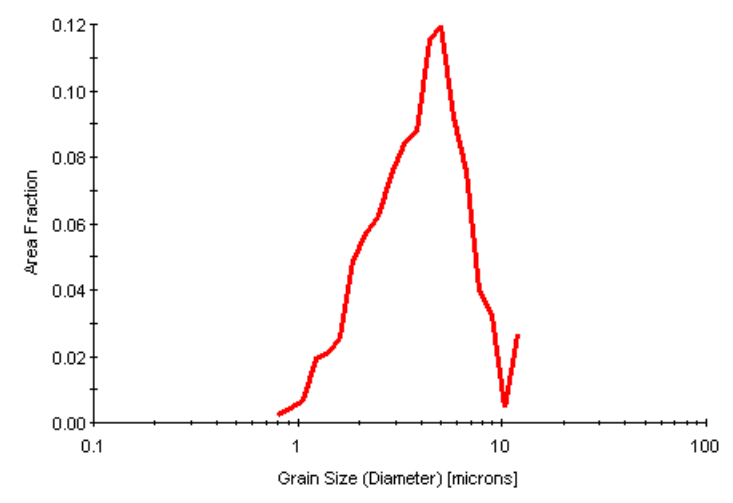

Figura 101 - Tamanho de Grão para a condição de 2 passes sem inversão com tratamento térmico de recozimento por 8 horas. a) Região de avanço da ferramenta b) Região de retrocesso da ferramenta.

A figura 102 apresenta a diferença de orientação dos grãos para ambos as regiões analisadas. Os dois lados após o tratamento térmico apresentam uma quantidade de contornos de baixo ângulo muito similar: $21 \%$ lado de avanço e $18 \%$ no lado de retrocesso. A diferença está na quantidade de contornos de alto ângulo que é superior no lado de avanço.
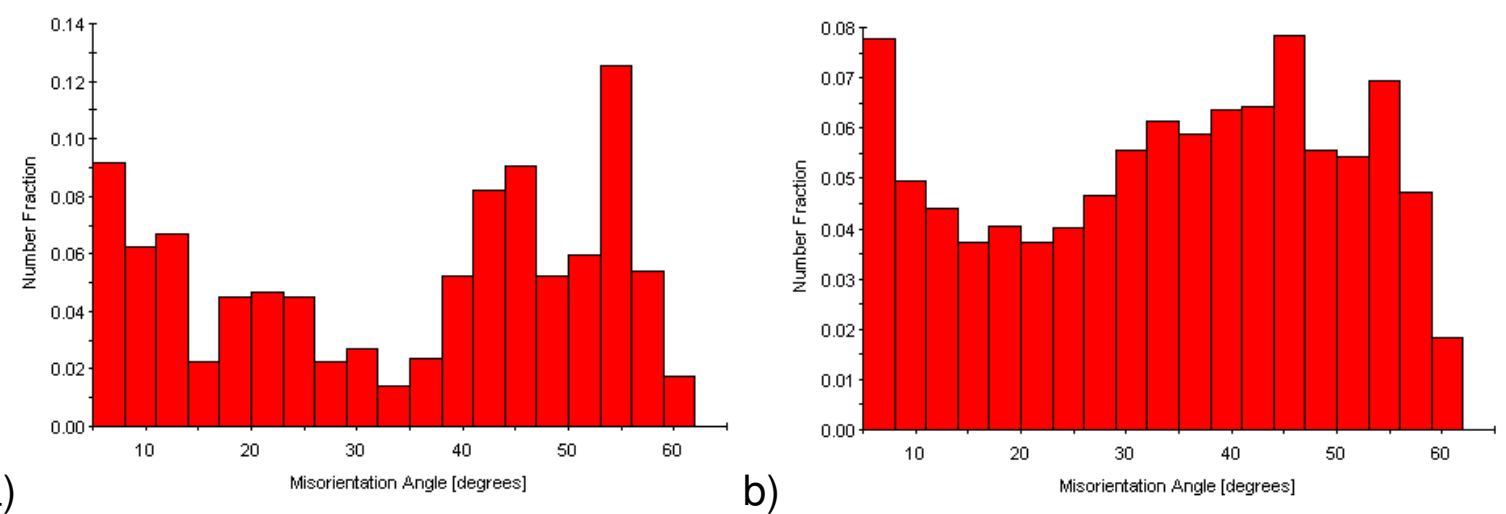

Figura 102 - Diferença de orientação dos grãos para a condição de 2 passes sem inversão com tratamento térmico de recozimento por 8 horas. a) Região de avanço da ferramenta b) Região de retrocesso da ferramenta. 
A título de comparação, e com base nos dados da figura 102 foi construída a porcentagem acumulada das diferenças de orientação entre os grãos para a soldagem com um passe do lado do avanço e do retrocesso, apresentada na figura 103. Foram ressaltadas na figura as porcentagens acumuladas até uma diferença de orientação de $5^{\circ}$ e de $15^{\circ}$ e o valor médio da orientação da região para $50 \%$ da porcentagem acumulada.

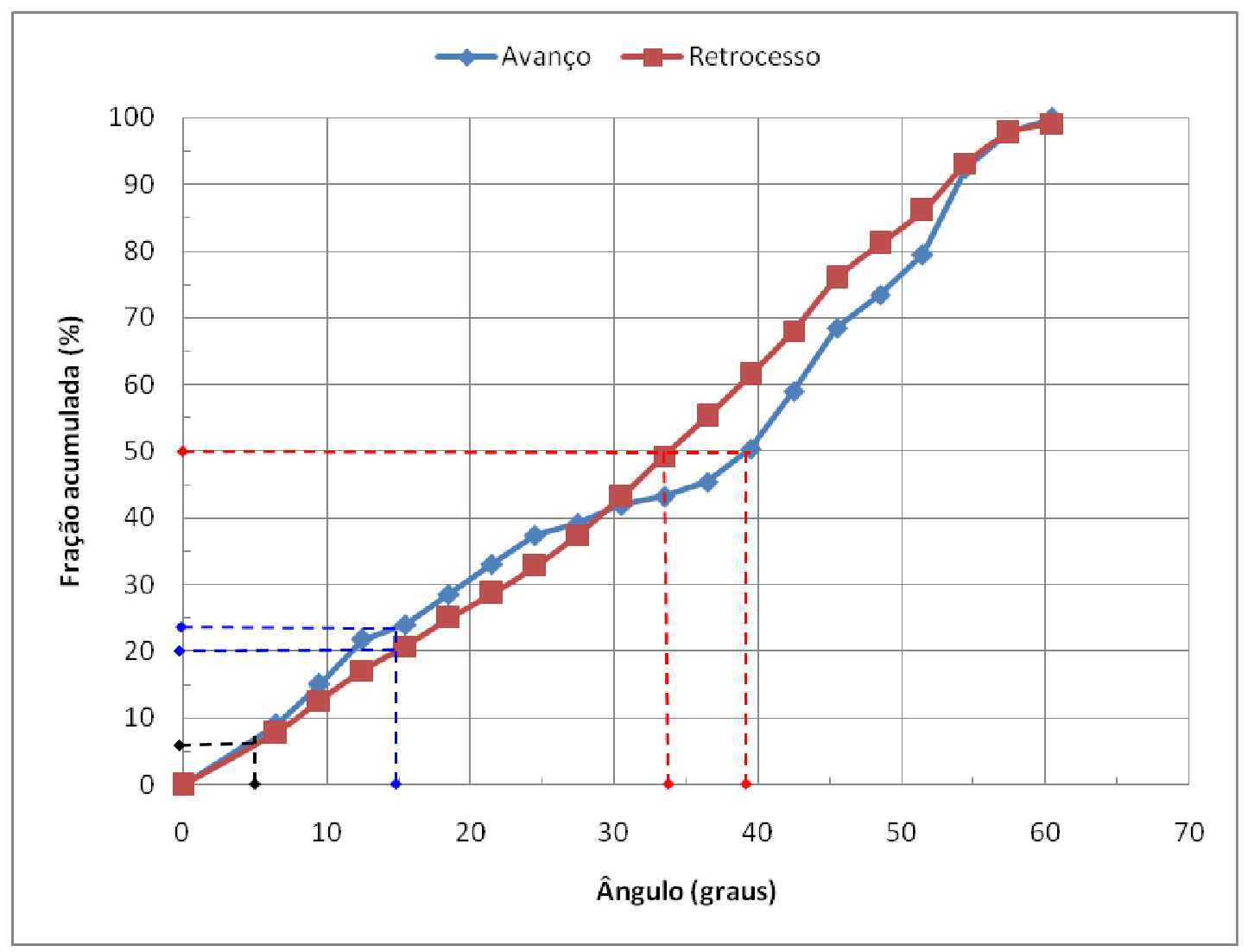

Figura 103 - Comparação entre as diferenças de orientação dos grãos do cordão de solda com dois passes sem reversão e com tratamento térmico de solubilização, no lado do avanço e do retrocesso, comparado com o metal de base.

Com base na figura 103 têm-se os seguintes valores:

a) Avanço:

i. Porcentagem acumulada até diferença de orientação de $5^{\circ}=6 \%$;

ii. Porcentagem acumulada até diferença de orientação de $15^{\circ}=20 \%$; 
iii. Valor médio da orientação da região $=39^{\circ}$.

b) Retrocesso:

i. Porcentagem acumulada até diferença de orientação de $5^{\circ}=6 \%$;

ii. Porcentagem acumulada até diferença de orientação de $15^{\circ}=22 \%$;

iii. Valor médio da orientação da região $=34^{\circ}$.

Os valores obtidos estão muito próximos, justificando os tamanhos de grão similares.

\subsubsection{Resumo dos valores obtidos com a técnica de EBSD.}

A tabela 20 resume os dados obtidos sobre a textura dos cordões nas diferentes condições de soldagem, e após o tratamento térmico de recozimento.

Tabela 20 - Dados de textura para as diferentes condições de soldagem sem tratamento térmico e com tratamento de recozimento por 8 horas.

\begin{tabular}{|c|c|c|c|c|c|c|c|c|c|}
\hline \multirow{2}{*}{$\begin{array}{c}\text { Contorno baixo } \\
\text { ângulo }\end{array}$} & \multirow{2}{*}{$\begin{array}{l}\text { Metal de } \\
\text { base }\end{array}$} & \multicolumn{2}{|c|}{ Um passe } & \multicolumn{2}{|c|}{$\begin{array}{c}\text { Dois passes sem } \\
\text { rev. }\end{array}$} & \multicolumn{2}{|c|}{$\begin{array}{c}\text { Dois passes } \\
\text { com rev. }\end{array}$} & \multicolumn{2}{|c|}{$\begin{array}{c}\text { Dois passes sem } \\
\text { rev. e c/ ToTo }\end{array}$} \\
\hline & & Av. & Ret. & Av. & Ret. & Av. & Ret. & Av. & Ret. \\
\hline * até $5^{\circ}(\%)$ & 7 & 10 & 25 & 5 & 20 & 10 & 3 & 6 & 6 \\
\hline * até 15우 & 24 & 23 & 71 & 21 & 50 & 34 & 9 & 20 & 22 \\
\hline Orient. Média $\left({ }^{\circ}\right)$ & 38 & 33 & 9 & 34 & 15 & 29 & 37 & 39 & 34 \\
\hline Tam. grão médio( $\mu \mathrm{m})$ & 34 & 5 & 22 & 5 & 12 & 5 & 3 & 6 & 5 \\
\hline Textura $^{(*)}$ & Cubo & Cubo ${ }^{(* *)}$ & Cubo & Inexis. & $\begin{array}{c}\text { Goss e } \\
\text { Cobre }\end{array}$ & Cubo & Latão & Cubo & Inexis. \\
\hline
\end{tabular}

$\left.{ }^{*}\right)$ Orientação das texturas:

Cubo (C) $\left\{\begin{array}{lllll}1 & 0 & 0\end{array}<<0 \begin{array}{lll}0 & 1>\end{array}\right.$

Goss $(G),[011]$ (1 000$)$

Cobre $(\mathrm{Cu}),(112)(111 \overline{1})$

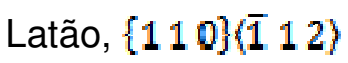

$\left.{ }^{* *}\right)$ Textura fraca.

Os dados obtidos indicam as mesmas distribuições de contornos de baixo ângulo para o lado de avanço da ferramenta, com um tamanho de grão médio medido pelo 
EBSD de $5 \mu \mathrm{m}$ em todas as condições de soldagem. A orientação média dos contornos de grão no lado de avanço permaneceu constante.

Para o lado de retrocesso, a quantidade de contornos de baixo ângulo até $5^{\circ}$ cai no segundo passe e novamente no segundo passe com inversão de rotação. Esta queda está relacionada com os modos de deformação do processo de soldagem. $\mathrm{Na}$ região de retrocesso ocorre uma deformação severa por extrusão do material, levando a formação de contornos de baixo ângulo. A região inclusive apresenta uma componente de textura típica do processo de extrusão. Com o segundo passe parte destes contornos são recuperados e recristalizados, dependendo da temperatura atingida durante a soldagem, elevando a fração de contornos de alto ângulo. Notase que a média de orientação dos grãos cresce com a seqüência dos passes, com valores maiores no lado do retrocesso. Com o aumento da diferença média de orientação dos grãos também ocorre a diminuição dos grãos, sugerindo a ocorrência de recristalização com a nucleação de novos grãos.

Com o tratamento térmico de recozimento a distribuição das diferenças de orientação retorna aos valores iniciais do metal de base, porém o grão permanece refinado no cordão de solda. O lado do retrocesso ficou com valores dos parâmetros medidos muito parecido com o lado de avanço. A componente de textura no lado de retrocesso do material desaparece e surge uma componente no lado de avanço do material do tipo Cubo, que é típica de ligas de alumínio recristalizadas.

\subsection{Determinação das energias de ativação}

O resultado do calorímetro para uma amostra do metal de base submetida ao tratamento de solubilização está apresentado na figura 104. Foram identificadas as 
precipitações das fases $\beta$, $\beta$ " e $\beta$ e a dissolução da fase $\beta$. Devido ao tratamento térmico prévio submetido e pouca deformação da amostra não se identifica o pico referente a recristalização.

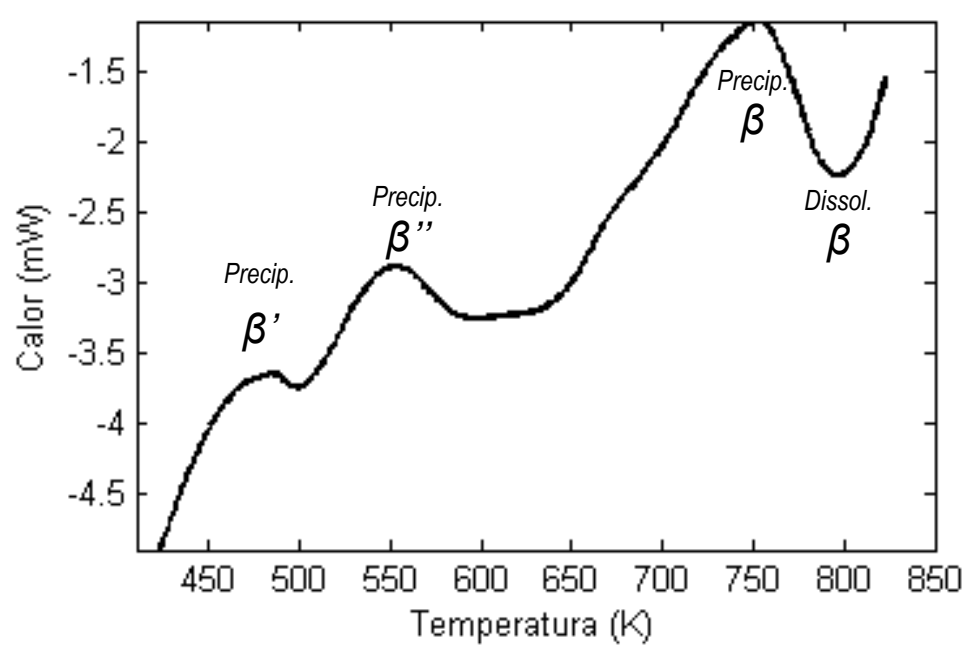

Figura 104 - Curva de energia obtida por calorimetria diferencial em amostra do metal de base(AA 6063T6) após tratamento de solubilização. Velocidade de aquecimento $0,17 \mathrm{Ks}^{-1}$.

A tabela 21 apresenta os resultados obtidos para as diferentes temperaturas de reação para as velocidades de aquecimento ensaiadas. A tabela 22 apresenta os cálculos das energias de ativação de dissolução dos precipitados nas regiões do cordão de avanço e retrocesso, na condição como soldado, utilizando a equação (13).

As tabelas 23 à 26 apresentam os mesmos cálculos para o cordão com dois passes sem inversão da rotação e para o cordão com dois passes com inversão da rotação. Para a liga AA 6063 utilizada a relação entre as concentrações de $\mathrm{Mg}$ e Si é: $\mathrm{C}_{\mathrm{Mg}} / \mathrm{C}_{\mathrm{Si}}$ $<1,7$. Para esta condição conforme a tabela 3 , grande parte das energias de ativação obtidas pelo método de Kissinger estão abaixo dos valores encontrados na literatura.

As altas deformações do processo SALM, o tamanho de grão refinado e a quantidade de contornos instáveis alteram as energias de precipitação. 
Os contornos de subgrão originados pelas discordâncias ancoradas apresentam campos de tensões elevados. Estes campos de tensões facilitam os fenômenos de difusão no material.

As energias de ativação medidas para a solubilização são mais baixas para dois passes do que para um passe somente. Os valores obtidos para dois passes sem inversão e um passe estão próximos aos valores da literatura, sendo os valores medidos para dois passes com inversão os mais baixos. Estes valores baixos podem ser explicados pelo refinamento que ocorre na estrutura, a condição de dois passes com inversão produz o menor tamanho de grão e desta forma aumenta a difusão pelo aumento de área de contorno de grão. Esta condição também apresenta as maiores desorientações médias entre os grãos que aumentando a fração de contornos de alto ângulo que são caminhos preferências para a difusão.

A dissolução do precipitado $\beta$ que precipitou nos contornos de grão irá ocorrer com maior velocidade em materiais com maior área de contorno de grão, diminuindo assim a sua energia de ativação. 
Tabela 21 - Temperaturas de dissolução para diferentes velocidades de aquecimento. Cordão com 1 passe na condição como soldado.

\begin{tabular}{lrr} 
Cordão & & \\
\hline 1 Passe - Centro & Graus/s & $\begin{array}{r}\text { Dissolução } \\
\text { (K) }\end{array}$ \\
& & \\
& 0,17 & 787,80 \\
& 0,33 & 808,48 \\
& 0,50 & 823,15 \\
1 Passe - Avanço & & \\
& & \\
& 0,17 & 779,64 \\
& 0,33 & 789,35 \\
1 Passe - Retrocesso & 0,50 & 803,15 \\
& & \\
& & \\
& 0,17 & 779,67 \\
& 0,33 & 798,31 \\
& 0,50 & 803,51 \\
\hline
\end{tabular}

Tabela 22 - Energia de ativação calculada através da inclinação da reta obtida por interpolação linear. Uma estimativa do erro da interpolação também é fornecida. Cordão com 1 passe na condição como soldado.

\begin{tabular}{lrr} 
Cordão & & \\
\hline 1 Passe - Centro & inclinação & $-18.635,17$ \\
& erro & 820,33 \\
& $r$ & 1,00 \\
& $\mathbf{Q}(\mathbf{k J} / \mathbf{m o l})$ & $\mathbf{1 5 4 , 9 4}$ \\
& & solubil \\
1 Passe - Avanço & inclinação & $-27.027,98$ \\
& erro & $7.070,31$ \\
& $r$ & 0,94 \\
& $\mathbf{Q}(\mathbf{k J} / \mathbf{m o l})$ & $\mathbf{2 2 4 , 7 2}$ \\
& & solubil \\
1 Passe - Retrocesso & inclinação & $-25.737,22$ \\
& erro & $4.690,12$ \\
& $r$ & 0,97 \\
& $\mathbf{Q}$ (kJ/mol) & $\mathbf{2 1 3 , 9 9}$ \\
\hline
\end{tabular}


Tabela 23 - Temperaturas de dissolução para diferentes velocidades de aquecimento. Cordão com 2 passes sem inversão, na condição como soldado.

Cordão

2 Passes sem inv. - Centro

Graus/s solubil

$\begin{array}{ll}0,167 & 780,50 \\ 0,333 & 786,34 \\ 0,500 & 801,64\end{array}$

2 Passes sem inv. - Avanço

$\begin{array}{ll}0,167 & 788,15 \\ 0,333 & 805,73 \\ 0,500 & 823,44\end{array}$

2 Passes sem inv. - Retroc.

\begin{tabular}{ll}
0,167 & 782,87 \\
0,333 & 807,57 \\
0,500 & 809,20 \\
\hline
\end{tabular}

Tabela 24 - Energia de ativação calculada através da inclinação da reta obtida por interpolação linear. Uma estimativa do erro da interpolação também é fornecida. Cordão com 2 passes sem inversão, na condição como soldado.

\begin{tabular}{|c|c|c|}
\hline Cordão & & \\
\hline & & solubil \\
\hline 2 Passes sem inv. - Centro & inclinação & $-27821,17$ \\
\hline & erro & 12320,91 \\
\hline & $r$ & 0,84 \\
\hline & $Q(\mathrm{~kJ} / \mathrm{mol})$ & 231,32 \\
\hline & & solubil \\
\hline 2 Passes sem inv. - Avanço & inclinação & $-18621,72$ \\
\hline & erro & 2855,27 \\
\hline & $r$ & 0,98 \\
\hline & $Q(\mathrm{~kJ} / \mathrm{mol})$ & 154,83 \\
\hline & & solubil \\
\hline 2 Passes sem inv. - Retrocesso & inclinação & $-21030,20$ \\
\hline & erro & 7494,18 \\
\hline & $r$ & 0,89 \\
\hline & $Q(\mathrm{~kJ} / \mathrm{mol})$ & 174,85 \\
\hline
\end{tabular}


Tabela 25 - Temperaturas de dissolução para diferentes velocidades de aquecimento. Cordão com 2 passes com inversão, na condição como soldado.

\section{Cordão}

2 Passes com inv. - Centro

$$
\text { Graus/s solubil }
$$

2 Passes com inv. Centro

$\begin{array}{ll}0,167 & 781,36 \\ 0,333 & 809,51 \\ 0,500 & 823,73\end{array}$

2 Passes com inv. - Avanço

$\begin{array}{ll}0,167 & 783,15 \\ 0,333 & 810,25 \\ 0,500 & 823,97\end{array}$

2 Passes com inv. - Retrocesso

\begin{tabular}{ll}
0,167 & 779,62 \\
0,333 & 809,77 \\
0,500 & 822,14 \\
\hline
\end{tabular}

Tabela 26 - Energia de ativação calculada através da inclinação da reta obtida por interpolação linear. Uma estimativa do erro da interpolação também é fornecida. Cordão com 2 passes com inversão, na condição como soldado.

\begin{tabular}{|c|c|c|}
\hline Cordão & & \\
\hline & & solubil \\
\hline 2 Passes com inv. - Centro & inclinação & $-14917,51$ \\
\hline & erro & 821,07 \\
\hline & $r$ & 1,00 \\
\hline & $Q(\mathrm{~kJ} / \mathrm{mol})$ & 124,03 \\
\hline & & solubil \\
\hline 2 Passes com inv. - Avanço & inclinação & $-15590,72$ \\
\hline & erro & 840,90 \\
\hline & $r$ & 1,00 \\
\hline & $Q(\mathrm{~kJ} / \mathrm{mol})$ & 129,63 \\
\hline & & solubil \\
\hline 2 Passes com inv. - Retrocesso & inclinação & $-14556,80$ \\
\hline & erro & 1589,11 \\
\hline & $r$ & 0,99 \\
\hline & $Q(\mathrm{~kJ} / \mathrm{mol})$ & 121,03 \\
\hline
\end{tabular}




\subsection{Ensaios de microdurezas}

Os resultados dos perfis de microdureza para as condições como soldado (CS), solubilizada $(\mathrm{S})$, envelhecida $(\mathrm{E})$ e recozida $(\mathrm{R})$ estão ilustrados na figura 105 à 113. Junto com as medições de dureza são apresentadas as microestruturas da região analisada.
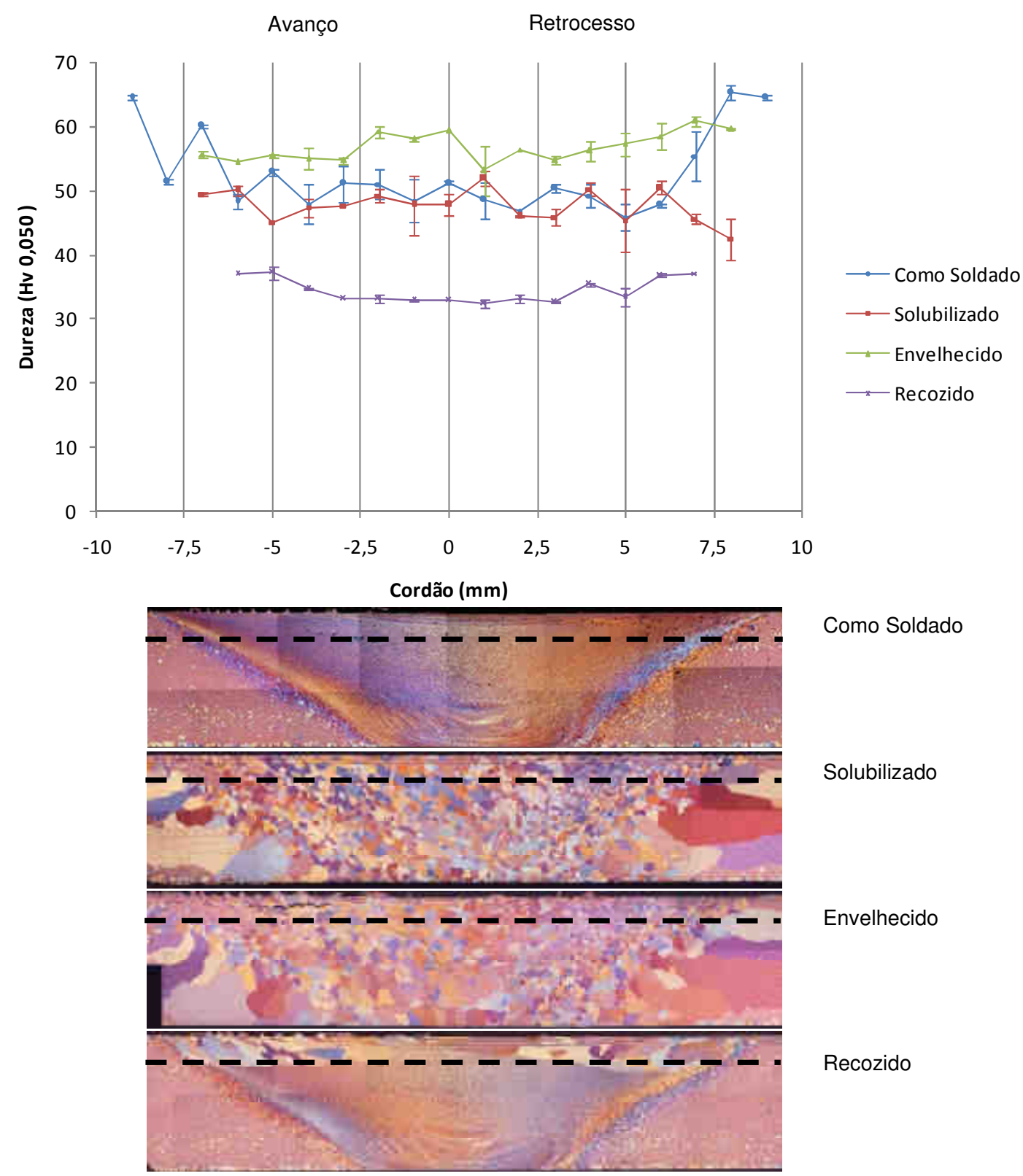

Como Soldado

Solubilizado

Envelhecido

Recozido

Figura 105 - Perfis de Microdurezas de cordão de solda SALM de um passe nas condições tratadas CS, S, E e R. As impressões foram realizadas no corte frontal do cordão. Ataque Barker 1,8\%. 

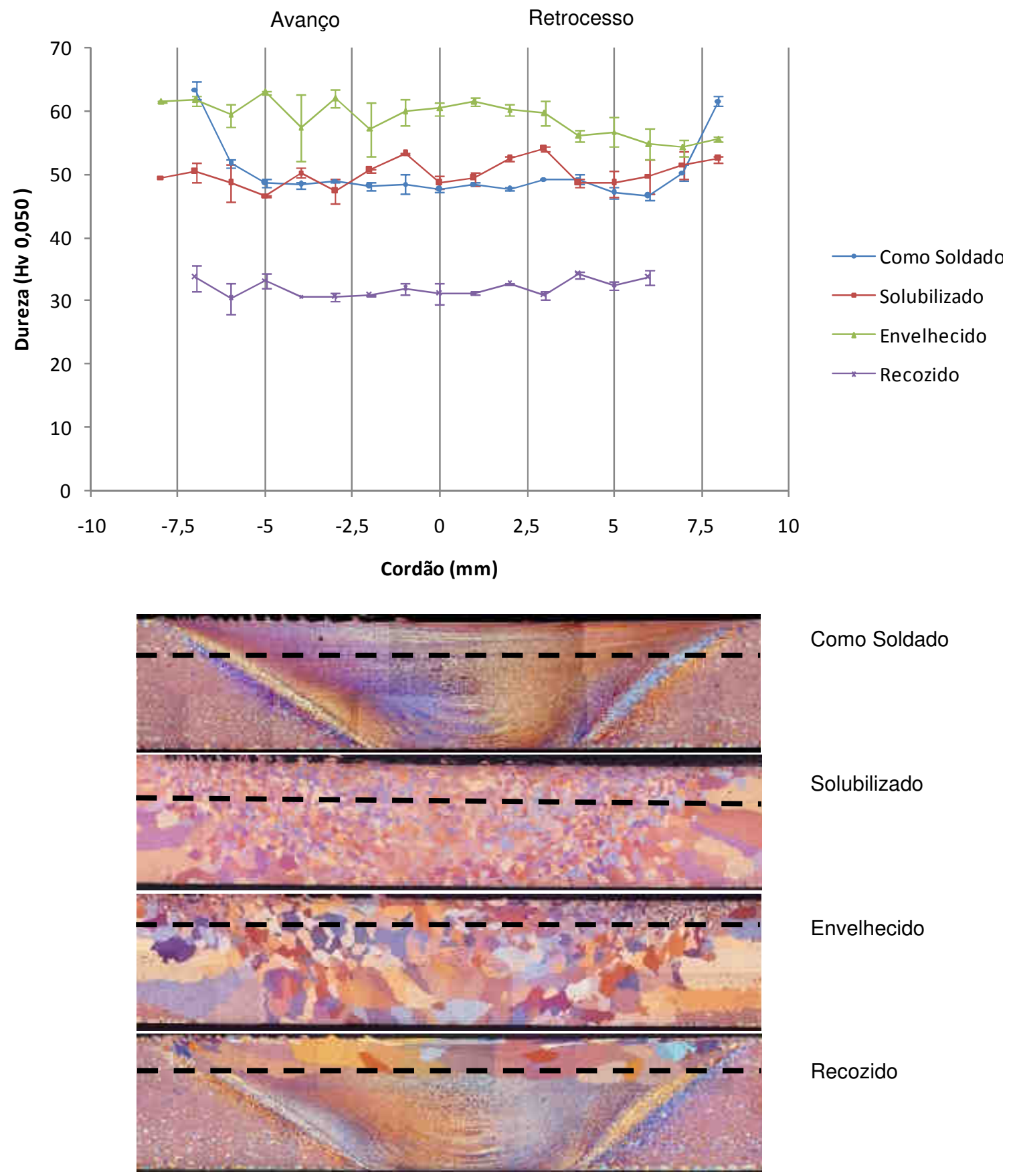

Como Soldado

Solubilizado

Envelhecido

Recozido

Figura 106 - Perfis de Microdurezas de cordão de solda SALM de dois passes, sem inversão de rotação no segundo passe, nas condições tratadas CS, S, E e R. As impressões foram realizadas no corte frontal do cordão. 

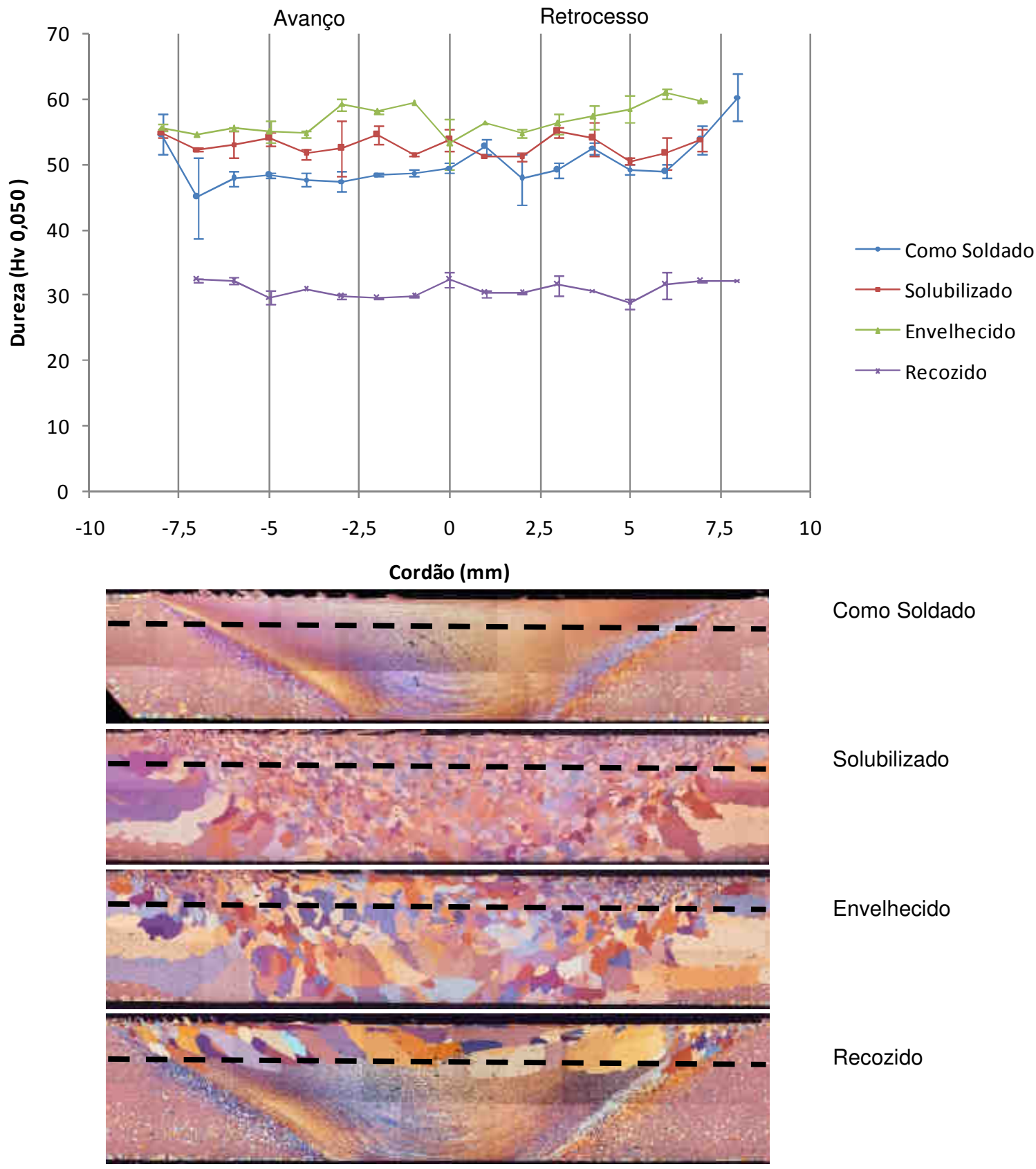

Como Soldado

Solubilizado

Envelhecido

Recozido

Figura 107 - Perfis de Microdurezas de cordão de solda SALM de dois passes, com inversão de rotação no segundo passe, nas condições tratadas CS, S, E e R. As impressões foram realizadas no corte frontal do cordão. 

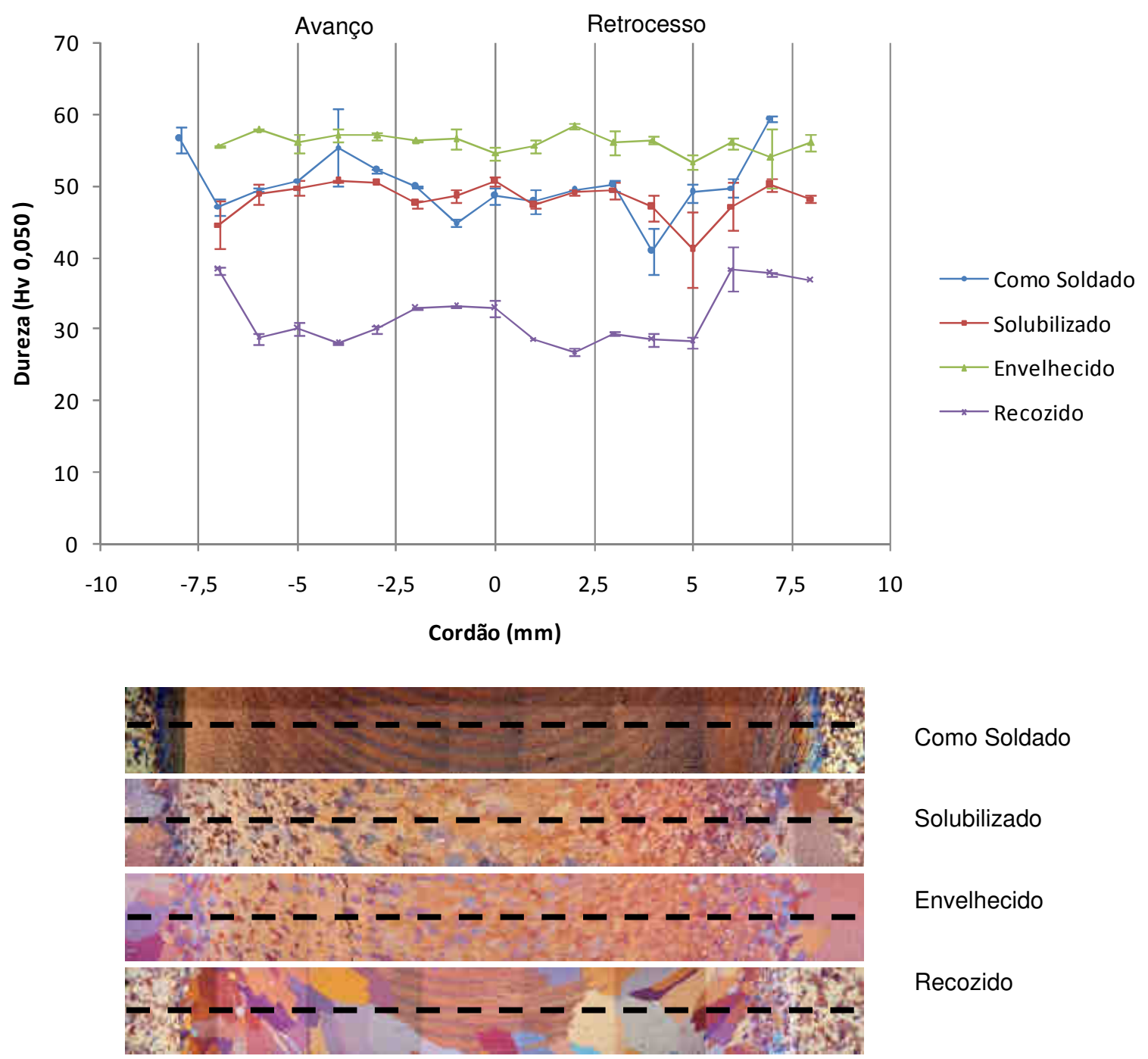

Como Soldado

Solubilizado

Envelhecido

Recozido

Figura 108 - Perfis de Microdurezas de cordão de solda SALM de um passe nas condições tratadas CS, S, E e R. As impressões foram realizadas na região superior do cordão. 

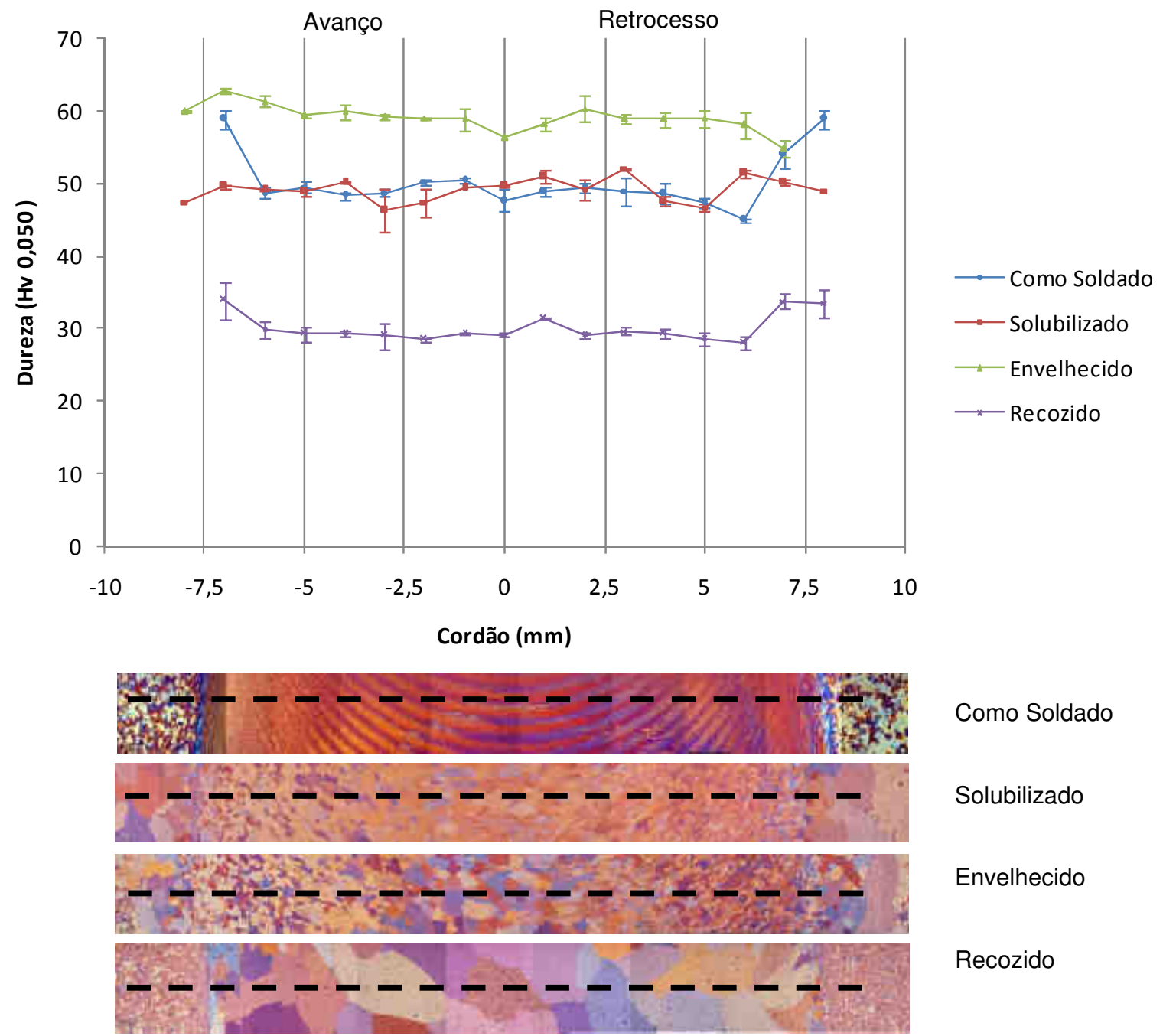

\section{Como Soldado}

Solubilizado

Envelhecido

Recozido

Figura 109 - Perfis de Microdurezas de cordão de solda SALM de dois passes, sem inversão de rotação no segundo passe, nas condições tratadas CS, S, E e R. As impressões foram realizadas na região superior do cordão. 

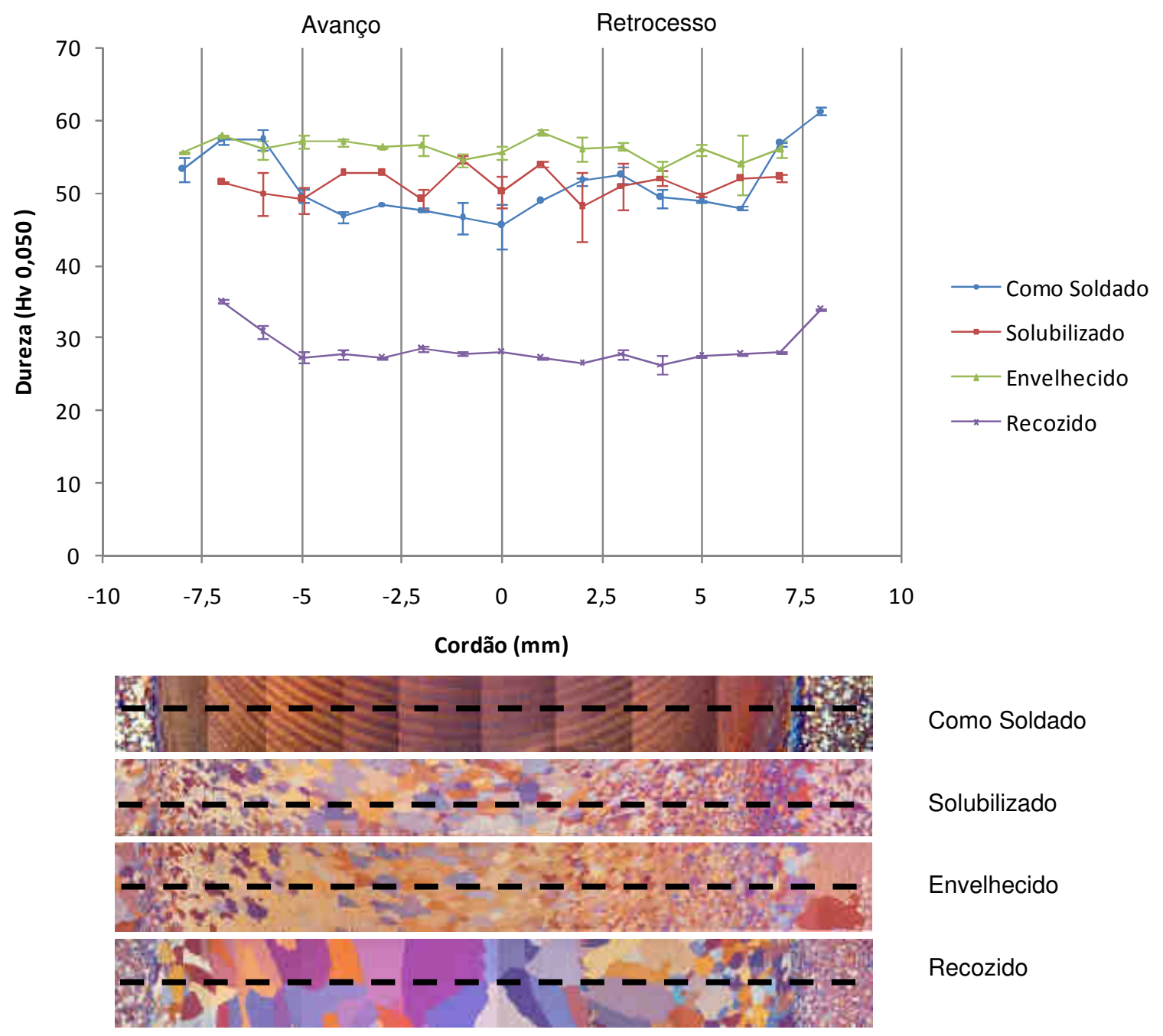

Como Soldado

Solubilizado

Envelhecido

Recozido

Figura 110 - Perfis de Microdurezas de cordão de solda SALM de dois passes, com inversão de rotação no segundo passe, nas condições tratadas CS, S, E e R. As impressões foram realizadas na região superior do cordão. 

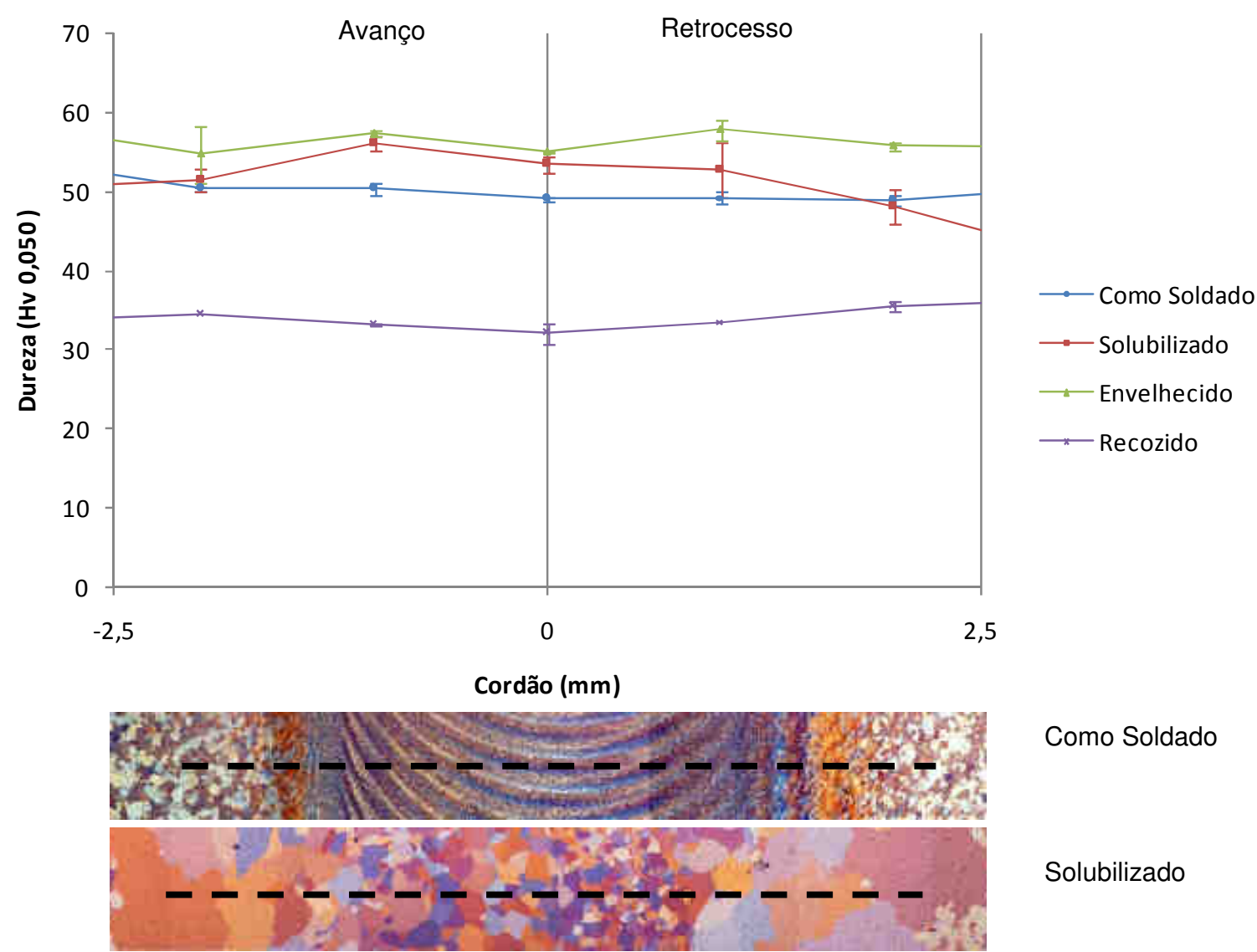

Como Soldado

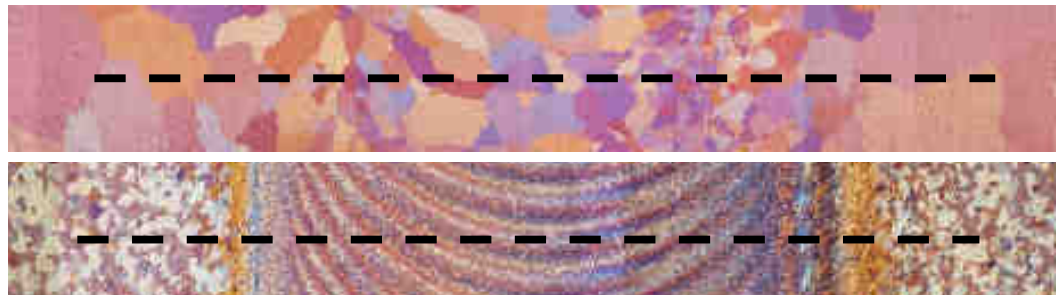

Envelhecido

Recozido

Figura 111 - Perfis de Microdurezas de cordão de solda SALM de um passe nas condições tratadas CS, S, E e R. As impressões foram realizadas na raiz do cordão. 

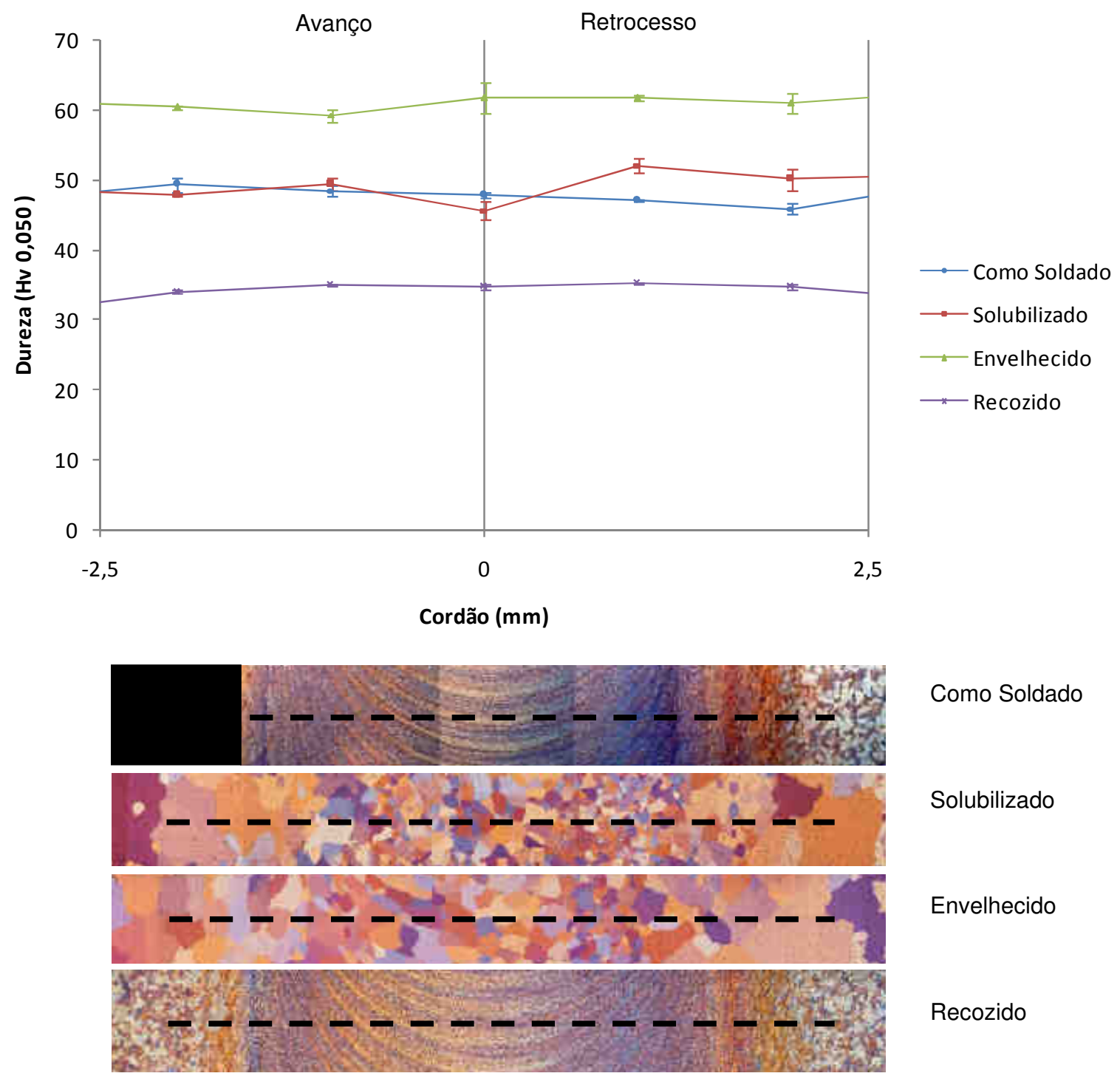

Solubilizado

Envelhecido

Recozido

Figura 112 - Perfis de Microdurezas de cordão de solda SALM de dois passes, sem inversão de rotação no segundo passe, nas condições tratadas CS, S, E e R. As impressões foram realizadas na raiz do cordão. 

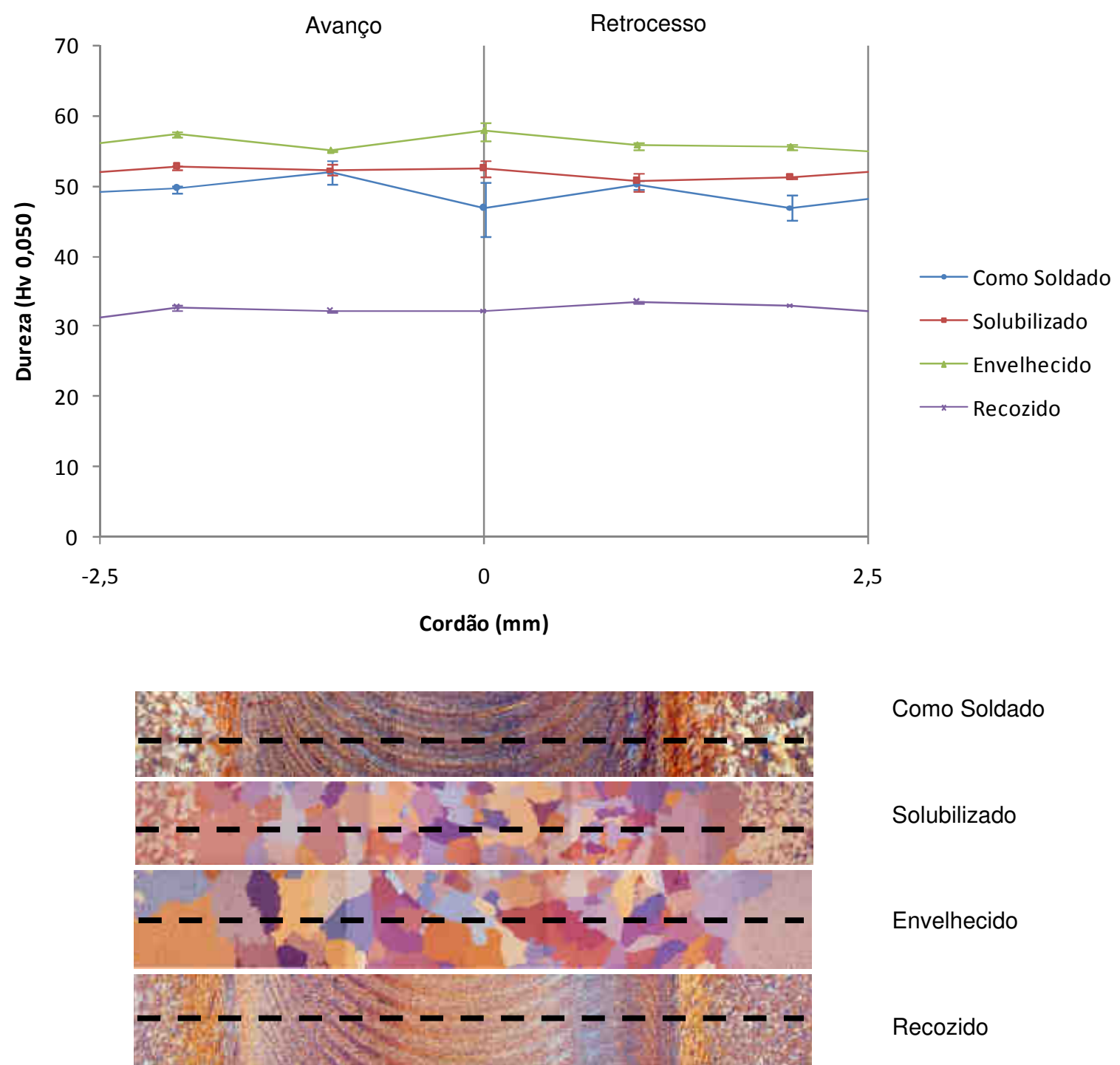

Como Soldado

Solubilizado

Envelhecido

Recozido

Figura 113 - Perfis de Microdurezas de cordão de solda SALM de 2 passes, com inversão de rotação no segundo passe, nas condições tratadas CS, S, E e R. As impressões foram realizadas na raiz do cordão.

A condição como soldada apresentou uma dureza inferior ao material de base dentro do cordão, devido às altas temperaturas de soldagem que solubilizam todos os precipitados responsáveis pelo endurecimento desta liga. Na ZTMA ocorreu o endurecimento do material devido a precipitação das fases $\beta^{\prime}$ e $\beta$. Este endurecimento segue até o material de base.

A condição solubilizada por 2 horas a $863 \mathrm{~K}\left(590^{\circ} \mathrm{C}\right)$ apresentou dureza ao longo do perfil medido próxima aos valores dentro do cordão da condição como soldada. Isto 
indica que o cordão na condição como soldada está solubilizado. As diferenças de dureza na ZTMA e em relação ao material de base não são mais identificadas.

A condição envelhecida por 8 horas a $453 \mathrm{~K}\left(180^{\circ} \mathrm{C}\right)$, previamente solubilizada, apresentou as maiores durezas de cordão, em todas as posições. O aumento de dureza é proveniente da precipitação das fases $\beta$ e $\beta$ '. Não é possível identificar diferenças entre o cordão, a ZTMA e o metal de base.

A condição recozida por 8 horas a 623K $\left(350^{\circ} \mathrm{C}\right)$ não apresentou variação de dureza para as condições de soldagem de um passe, dois passes sem inversão e dois passes com inversão. É possível identificar a variação de dureza resultante da recristalização secundária do cordão, no perfil superior nas figuras 108 a 110 . A microestrutura com os grãos refinados apresenta uma dureza superior. A temperatura de recozimento é superior a temperatura de recristalização do material eliminando assim a energia armazenada da deformação por recristalização, levando a uma dureza final inferior. A temperatura de $623 \mathrm{~K}\left(350^{\circ} \mathrm{C}\right)$ não solubiliza a fase de $\beta^{\prime}$ mantendo a dureza da ZTMA e do metal de base superior.

Nos tratamentos térmicos realizados e na condição como soldada não foi identificada alteração de dureza proveniente das condições de soldagem. 


\section{Conclusões}

Tendo em vista os materiais, métodos de análise e condições experimentais é possível concluir que:

a) O cordão de solda é assimétrico, e suas dimensões de largura da face do cordão aumentam de 3,1 e 3,5 \% com as condições de dois passes e dois passes com inversão, respectivamente. A dimensão de raiz altera de 8,2 e $3,1 \%$ com as condições de dois passes e dois passes com inversão, respectivamente. Esta variação de dimensão está associada ao fluxo de material durante a soldagem.

b) Devido aos fluxos de material apresentados na figura 18 ocorre a alteração das áreas da ZTMA nos lados de avanço e retrocesso, conforme a condição de soldagem. A condição de dois passes aumenta a área de avanço devido ao fluxo das regiões I a IV. A extrusão na região $V$ de retrocesso é reduzida. Na condição com inversão de passe as áreas da ZTMA se tornam similares.

c) Com relação ao tamanho de grão no cordão pode-se dizer que os grãos alongados na região da ZTMA diminuem de tamanho com o segundo passe. Este efeito é mais significativo na condição de dois passes com inversão. As áreas de retrocesso da ZTMA nas condições de dois passes e dois passes com inversão são mais refinadas. Já os grãos equiaxiais crescem no segundo passe sem inversão e diminuem no segundo passe com inversão. O crescimento ocorre em grãos recristalizados, e a diminuição ocorre com a nucleação de novos grãos. As diferenças médias de orientação dos contornos de grão são maiores para a condição de dois passes com inversão evidenciando a criação de novos contornos de alto ângulo. 
d) Dependendo do tipo de tratamento térmico pós-soldagem, o cordão está sujeito a recristalização secundária, que está relacionada com as condições de soldagem. Para a condição de soldagem com inversão foram obtidas as maiores áreas de recristalização secundária para o tratamento de recozimento de oito horas.

e) No tratamento térmico o tamanho de grão equiaxial do cordão de solda é influenciado pela condição de soldagem e pelo tempo de tratamento. As diferenças de tamanhos de grão entre as áreas de avanço e retrocesso permanecem similares a condição anterior aos tratamentos térmicos.

f) No tratamento térmico para os grãos alongados da ZTMA notou-se que os grãos continuam menores do lado de retrocesso, mesmo após os tratamentos térmicos. A condição de dois passes apresenta a menor diferença entre os tamanhos de grão da região de avanço e retrocesso da ZTMA para os tratamentos térmicos de recozimento, solubilização e envelhecimento

g) A quantidade de contornos de baixo ângulo $\left(<15^{\circ}\right)$ se altera com a condição de soldagem. Estas quantidades estão relacionadas com as deformações locais destas regiões. O lado de retrocesso apresenta a conformação mais severa, que resulta numa microestrutura com a maior quantidade de contornos de baixo ângulo. Esta quantidade de contornos de baixo ângulo está relacionada com a quantidade inicial presente antes do cordão, como foi verificado na condição de dois passes com inversão.

h) A diferença de orientação média dos contornos de grão do lado do retrocesso decresce de $38^{\circ}$ no metal de base para $9^{\circ}$ quando é feita a soldagem em um passe, passando para $15^{\circ}$ depois do segundo passe sem inversão. O segundo passe com inversão apresenta um crescimento na diferença de orientação média dos grãos para $37^{\circ}$. Este aumento está relacionado com os fluxos de material, que no segundo 
passe com inversão ocorrem de maneira inversa durante a soldagem levando a maiores heterogeneidades na deformação. A região de avanço não teve alterações significativas nas diferenças de orientação de contornos de grão com as condições de soldagem.

i) Quanto maior foi a desorientação média dos contornos de grão, menor foi o tamanho médio de grão. Este fato pode ter sido causado pela recristalização dinâmica, que ocorreu para a diminuição da energia armazenada na deformação durante a soldagem.

j) As texturas obtidas são típicas de extrusão de ligas de alumínio, como no lado de retrocesso para dois passes sem inversão, que está de acordo com a região II do modelo apresentado na figura 18.

k) O tratamento térmico de recozimento por oito horas recupera o cordão na sua condição inicial. As distribuições de contornos de baixo ângulo retornam a valores similares aos do metal de base. No lado de avanço o tratamento térmico criou a componente de textura do tipo cubo.

I) A energia de ativação aparente para a solubilização do precipitado $\beta$ decai com o aumento da orientação média dos contornos de grão e a diminuição dos contornos de grão para valores inferiores aos citados na literatura.

m) A solubilização apresentou a mesma dureza na região do cordão do que na condição como soldado devido a condição solubilizada do cordão oriunda do aquecimento e deformação processo de soldagem.

n) $\mathrm{O}$ endurecimento pelo efeito de refinamento de grão no cordão é de $15 \mathrm{Hv}$ quando se comparou uma região recristalizada secundariamente e outra não recristalizada. 
o) O estado envelhecido apresentou a maior dureza nos cordões em todas as posições, enquanto que o estado recozido é a condição de menor dureza em todas as posições do cordão. 


\section{Sugestões de Trabalhos Futuros}

a) Confirmar por TEM ou FEG SEM as solubilizações dos precipitados betas conforme resultados do calorímetro.

b) Realizar a caracterização por EBSD da região central do cordão.

c) Caracterizar a energia armazenada para recristalização em diferentes condições de soldagem e geometrias de ferramentas.

d) Caracterizar as regiões dos cordões quanto as transformações de fase que ocorrem, utilizando a técnica de calorimetria por DSC.

e) Desenvolver um modelo de processo que combine as condições de soldagem com os fenômenos de recuperação dinâmica do material utilizando o parâmetro de Zener Hollomon. 


\section{REFERÊNCIAS BIBLIOGRÁFICAS}

1.Mishra, R. S. Preface to the viewpoint set on friction stir processing. Scripta Materialia, v.58, n.5, p.325-326, Mar. 2008.

2.Arbegast, W. J. Friction Stir Welding After a Decade of Development It's not just welding anymore. Welding Journal, v.85, n.3, p.28-35, Mar. 2006.

3.Lamarre, A.; Dupuis, O.; Moles, M. Complete inspection of friction stir welds in aluminum using ultrasonic and eddy current arrays. Trends in Welding Research: Proceedings of the 7th International Conference 2006.

4.Wood, M.; Larsson, S.; Dahlstrom, H. Environmental comparsion of FSW against MIG in Aluminium Railway Rolling Stock. In: 3rd International friction stir welding symposium. Port Island, Kobe, Japan, 27-28 Sept. 2001. p.15.

5.Defalco, J. Friction Stir Welding VS. Fusion Welding. Welding Journal, v.85, n.3, p.42-44, Mar. 2006.

6.Ding, J. et al. Friction Stir Welding Flies High at Nasa. Welding Journal, v.85, n.3, p.54-59, Mar. 2006.

7.Johnsen, M. R. Friction stir welding takes off at Boeing. Welding Journal, n.2, p.35-39, Feb. 1999.

8. Heat treatment developed for FSW aluminum plates. Advanced Materials \& Processes, v.164, n.5, p.25, May. 2006.

9.Brandi, S. D. Soldagem por atrito. In: E. Wainer. Soldagem: Processos e Metalurgia. São Paulo: Edgard Blücher Ltda, 1992, p.317-334.

10.Nicholas, E. D. Friction processing technologies. Disponível em: $<$ http://www.twi.co.uk/content/ksedn001.html>. Acesso em: Jul. 2008.

11.Campbell, G.; Stoller, T. Friction stir welding of armor grade aluminum plate. Welding Journal, n.12, p.45-47, Dec. 1999. 
12.Mendez, P. F.; Eagar, T. W. Welding Process for Aeronautics. Advanced Materials \& Processes, v.159, n.5, p.39-43, May. 2001.

13.Davis, J. R. Welding. In. Aluminium and Aluminium Alloys. Materials Park, USA: ASM International, 1994, p.376-419.

14.Irving, R. The auto industry gears up for. Welding Journal, v.79, n.11, p.63-68, Nov. 2000.

15.Menzemer, C. C. et al. A study of fusion zone microstructures of arc-welded joints made from dissimilar aluminum alloys. Journal of material engineering and performance, v.10, n.2, p.173-177, Apr. 2001.

16.Norman, A. F.; Harris, D. Properties of friction stir welded joints: A review of the literature. TWI Disponível em: <http://www.twi.co.uk/content/propertiesFSW review.pdf>. Acesso em: 30/Jul./2008.

17.Takai, H. et al. Application of friction stir welding to rolling stock body shell. In: 3rd international friction stir welding symposium. Port Island, Kobe, Japan, 27-28 Sept. 2001. p.7.

18.Smith, C. B. Friction stir welding in the automotive industry. In: Anual meeting aluminum automotive and joining symposia. New Orleans, USA, 12-14 Feb. 2001. Aluminium. Warrendale, USA: Minerals, Metals and Materials Society/AIME, p.175-185, 2001.

19.Kallee, S.; Nicholas, D. Friction Stir Welding at TWI. Descrição das atividades referentes a friction stir welding do instituto. Disponível em: <http://www.twi.co.uk/isp/PressArticles.jsp $>$. Acesso em: 10 de out. 2002.

20.Kallee, S. TWI works on friction stir welding for lightweight automotive structures. Metalurgia, v.64, n.4, p.119, Apr. 1997.

21.Lee, W. et al. Formability and Springback Evaluation of Friction Stir Welded Automotive Sheets. Friction Stir Welding and Processing IV, p.15, 2007.

22.Lynch, S. P. et al. Friction Stir Processing of a High - Damping Mn-Cu Alloy used for Marine Propellers. Materials Science Forum, v.426-432, p.2903-2908, 2003. 
23.Klingensmith, S.; Dupont, J. N.; Marder, A. R. Microstructural Characterization of a DoubleSided Friction Stir Weld on a Superaustenitic Stainless Steel. Welding Journal, p.77-84, May. 2005.

24.Lee, W. B. et al. Microstructural investigation of friction stir welded pure titanium. Materials Letters, v.59, n.26, p.3315-3318, Nov. 2005.

25.Ohishi, K. et al. The Influence of Friction Stir Processing on Microestruture and Properties of a Cast Nickel Aluminium Bronze Material. Materials Science Forum, v.426-432, p.2885-2890, 2003.

26.Dawes, C. J.; Thomas, W. M. Friction stir welds alluminum alloys. Welding Journal, v.75, n.3, p.41-45, Mar. 1996.

27.Greitmann, M. J.; Deimel, P. Rührreibschweißen (Friction Stir Welding) - eine innovative Verfahrenstechnologie

zum Fügen von Halbzeugen aus Aluminium. Otto - Graf - Journal, v.16, p.185-192, 2005.

28.Ouyang, J. H.; Kovacevic, R. Material flow and microstructure in the friction stir butt welds of the same and dissimilar aluminum alloys. Journal of material engineering and performance, v.11, n.1, p.51-63, Feb. 2002.

29.Prado, R. A. Tool wear in the friction-stir welding of aluminum alloy $6061+20 \% A l 2 O 3$ : a preliminary study. Sripta Materialia, v.45, p.75-80, 2001.

30.Friction stir welding - a star among the weld processes. Schweiss- \& Prüftechnik, v.54, n.11, p.178-179, 2000.

31.Colligan, K. et al. Friction stir welding of thick section 5083-H131 and 2195-T8P4 Aluminum Plates. In: 3rd International Friction Stir Welding Symposium. Port Island, Kobe, Japan, 27-28 Sept. 2001. p.15.

32.Skinner, M.; Edwards, R. L. Improvements to the FSW Process using the sef-reacting technology. Materials Science Forum, v.426-432, p.2849-2854, 2003.

33.Thomas, W. M.; Munns, I.; Smith, P. T. Friction Stir Welding of an Aluminium Alloy - Effects of Tool Geometry. TWI Industrial Memebers Report, n.688 Jan. 1999. 
34.Karlsson, L. Friction Stir Welding (FSW) - Framtidens Svetsmetod? Atividades de SALM na universidade e no mundo. Disponível em: <http://www.msm.cam.ac.uk/phasetrans/2003/FSW/SFMT-Presentation.ppt>. Acesso em: 30/Jul./2008.

35.Ryan, P.; Prangnell, P. B.; Williams, S. W. Epitaxial grain growth during surface modification of friction stir welded aerospace alloys by a pulsed laser system. Materials Science Forum, v.519521, Part 2, p.1169-1174, 2006.

36.Mandal, S.; Williamson, K. A thermomechanical hot channel approach for friction stir welding. Journal of Materials Processing Technology, v.174, n.1-3, p.190-194, 25 May. 2006.

37.Reynolds, A. P. Recent advances in friction stir welding process physics. In: Materials Solution. St Louis, USA, 9-11 Oct. 2000. Joining of advanced and speciality materials III. Materials Park, USA: ASM International, p.172-177, 2001.

38.Russel, M. J. Development and application of an analytical process model for friction stir welding. In: Anual meeting aluminum automotive and joining symposia. New Orleans, USA, 12-14 Feb. 2001. Aluminum. Warrendale, USA: Minerals, Metals and Materials Society/AIME, p.225$234,2001$.

39.Xu, S. Finite element simulation of material flow in friction stir welding. Science and technology of welding and joining, v.6, n.3, p.191-193, 2001.

40.Ashby, M. F.; Easterling, K. E. A first report on diagrams for grain grow in welds. Acta metall, v.30, p.1969-1978, 1982.

41.Faria, R. A.; Brandi, S. D. Mapa do crescimento de grão da ZAC de um aço inoxidável ferrítico do tipo 439 soldado pelo processo MIG. In: Encontro nacional de tecnologia de soldagem. Belo Horizonte, Brasil. 1999. XXV ENTS. São Paulo: Associação Brasileira de Soldagem, 1999.

42.Frigaard, O. Process modelling applied to friction stir welding of Al-Mg-Si alloys. In: ICAA 6. Toyohashi, Japan. 1998. Aluminum Alloys: Their physical and mechanical properties. Tokyo, Japan: Japan Institute of light metals, p.1477-1482, 1998.

43.Ion, J. C.; Easterling, K. E.; Ashby, M. F. A second report on diagrams of microstructure and hardness for heat affected zones in welds. Acta metall, v.32, n.11, p.1949-1962, 1984. 
44.Mcclure, J. C. Heat input and temperature distribution in friction stir welding. Journal of materials processing \& manufacturing science, v.7, n.2, p.163-172, Oct. 1998.

45.Mcclure, J. C. A thermal model of friction stir welding. In: International conference: Trends in welding research. Georgia, USA, 1-5 Jun. 1998. Proceedings of the 5th international conference: Trends in welding research. p.590-594, 1998.

46.Vilaca, P. et al. Quality assessment of friction stir welding joints via an analytical thermal model, iSTIR. Materials Science and Engineering A, v.445-446, p.501-508, Feb.

47.Vilaça, P.; Quintino, L.; Santos, J. F. D. iSTIR - Analytical thermal model for friction stir welding. Journal of materials processing technology, n.169, p.452-465, 2005.

48.Colegrove, P. A.; Shercliff, H. R. CFD modelling of friction stir welding of thick plate 7449 aluminium alloy. Science and technology of welding and joining, v.11, n.4, p.429-441, 2006.

49.Frigaard, O.; Grong, O.; Midling, O. T. A process model for friction stir welding of age hardening aluminum alloys. Metallurgical and Materials Transactions A, v.32, p.1189-1200, May. 2001.

50.Myhr, O. R.; Grong, O. Process modelling applied to 6082-T6 aluminium weldments I. Acta Materialia, v.39, n.11, p.2693-2702, 1991.

51.Myhr, O. R.; Grong, O. Process modelling applied to 6082-T6 aluminium weldments II. Acta Materialia, v.39, n.11, p.2703-2708, 1991.

52.Grong, O.; Shercliff, H. R. Microstructural modelling in metals processing. Progress in Materials Science, v.47, p.163-282, 2002.

53.Murr, L. E. Microstructures in friction stir welded metals. Journal of materials processing \& manufacturing science, v.7, n.2, p.145-161, Oct. 1998.

54.Sato, Y. S. Microstructural evolution of 6063 aluminum during friction stir welding. Metallurgical and Materials Transactions A, v.30A, p.2429-2437, Sept. 1999.

55.Arbegast, W. J. A flow partitioned deformation zone model for defect formation during friction stir welding. Scripta Materialia, n.58, p.372-376, 2008. 
56.Padilha, A. F.; Siciliano Jr, F. Encruamento, Recristalização, Crescimento de Grão e Textura. São Paulo: ABM. 2005. 232 p.

57.Mcnelley, T. R.; Swaminathan, S.; Su, J. Q. Recrystallization mechanisms during friction stir welding/processing of aluminum alloys. Scripta Materialia, v.58, n.5, p.349-354, Mar. 2008.

58.Haessner, F. Recrystallization of metallic materials. Stuttgart: Dr. Rieder Verlag GmbH. 1978. 98-99 p.

59.Doherty, R. D. et al. Current issues in recristallization: a review. Materials Science \& Engineering A, n.A238, p.219-274, 1997.

60.Campana, R. C. Parâmetros de processo, microestrutura e textura das ligas de alumínio AA 6063 e AA 6082 extrudadas. 2008. 115 p. Mestrado. - Escola Politécnica. Departamento de Engenharia Metalúrgica e de Materiais, Universidade de São Paulo, São Paulo, 2008.

61.Burke, J. E.; Turnbull, D. Recrystallization and Grain Growth. London: Pergamon Press, v.3. 1952

62.Dunn, C. G.; Walter, J. L. Secondary recrystallization. Recrystallization, Grain Growth and Textures. Ohio: American Society for Metals. 1966. 461-521 p.

63. Humphreys, F. J. A unified theory of recovery, recrystallization and grain growth, based on the stability and growth of celular microstructures-I. The basic model. Acta Metallurgica, v.45, n.10, p.4231-4240, 1997.

64.Yu, C. Y. et al. Evolution of microstructure during annealing of a severely deformed aluminum. Materials Science \& Engineering A, v.A366, p.310-317, 2004.

65.Lewandowska, M.; Wejrzanowski, T.; Kurzydlowski, K. J. Grain growth in ultrafine grained aluminium processed by hydrostatic extrusion. Journal of Materials science, n.43, p.7495-7500, 2008.

66.Lian, J.; Valiev, R. Z.; Baudelet, B. On the enhanced grain growth in ultrafine grained metals. Acta metallurgica et materialia, v.43, n.11, p.4165-4170, 1995.

67.Charit, I.; Mishra, R. S. Abnormal grain growth in friction stir processed alloys. Scripta Materialia, v.58, n.5, p.367-371, Mar. 2008. 
68.Sato, Y.; Kokawa, H. Microstructural characteristics in friction stir welded aluminum alloys. Welding International, v.15, n.9, p.693-698, 2001.

69.Olea, C. A. W. et al. A sub-structural analysis of friction stir welded joints in an AA6056 Alalloy in T4 and T6 temper conditions. Materials Science and Engineering A, v.454-455, n.5, p.52-62, 25 Apr. 2008.

70.Afify, N. G., A; Mostafa, M. S.; Abbady, G. Influence of Si concentration on the precipitation in Al-1at.\% Mg alloy. Journal of Alloys and Compounds, v.462, p.80-87, 2008.

71.Simar, A. A multiscale multiphysics investigation of aluminum friction stir welds: from thermal modelling to mechanical properties through precipitation evolution and hardening. 2006. 279 p. Doutor. - Faculté des Sciences Appliquées, Universit Catholique de Lovain, Louvain, 17-jul-2006.

72.Gupta, A. K.; Lloyd, D. J.; Court, S. A. Precipitation hardening in Al-Mg-Si alloys with and without excess Si. Materials Science \& Engineering A, v.A316, p.11-17, 2001.

73.Pino, D.; Acuña, L.; Luiggi, N. J. Study of the Mg2Si phase in A 6063 Al commercial alloy using dilatometric techniques. Materials Science Forum, v.217-222, p.833-838, 1996.

74.Kang, S. B. et al. Effect of cold rolling and aging treatment on mechanical property and precipitation behavior im a Al-Mg-Si alloy. Materials Science Forum, v.217-222, p.827-832, 1996.

75.Vedani, M. et al. DSC Analysis of strengthening precipitates in ultrafine Al-Mg-Si Alloys. Journal of Thermal Analysis and Calorimetry, v.87, n.1, p.277-284, 2007.

76.Sato, Y. S. Precipitation sequence in friction stir weld of 6063 aluminum during aging. Metallurgical and Materials Transactions A, v.30A, n.12, p.3125-3130, Dec. 1999.

77.Hori, H.; Makita, S.; Minamida, T. Joint strength of thick sheet welded by friction stir welding. In: 3rd International Friction Stir Welding Symposium. Port Island, Kobe, Japan, 27-28 Sept. 2001. p.7.

78.Shewmon, P. G. Transformations in Metals. New York: MacGraw-Hill. 1969. 394 p. (Materials Science and Engineering) 
79.Starink, M. J.; Deschamps, A.; Wang, S. C. The strength of friction stir welded and friction stir processed aluminium alloys. Scripta Materialia, n.58, p.377-382, 2008.

80.Masaki, K. et al. Experimental simulation of recrystallized microstructure in friction stir welded Al alloy using a plane-strain compression test. Scripta Materialia, v.58, n.5, p.355-360, Mar. 2008.

81.Reynolds, A. P. Visualization of material flow in autogenous friction stir. Science and technology of welding and joining, v.5, n.2, p.120-124, 2000.

82.Arbegast, W. J. Modeling friction stir joining as a metal working process. In: Hot Deformation of Aluminium Alloys III. Warrendale, PA, USA. 2003. TMS, p.313-327.

83.Karlsen, M. et al. SEM-EBSD Characterisation of the deformation microstructure in friction stir welded 2024 T351 Aluminium Alloy. Materials Science Forum, v.426-432, p.2861-2866, 2003.

84.Bastier, M. et al. Steady state thermomechanical modelling of friction stir welding. Science and technology of welding and joining, v.11, n.3, p.278-288, 2006.

85.Mahoney, M. W. et al. Properties of friction stir welded 7075 T651 aluminum. Metallurgical and Materials Transactions A, v.29, n.7, p.1955-1964, 1998.

86.Sato, Y. et al. Microtexture in the friction stir weld of an aluminum alloy. Metallurgical and Materials Transactions A, v.32A, n.4, p.941-948, 2001.

87.Fonda, R. W.; Wert, J.; Reynolds, A. P. Friction stir welding of single crystal aluminum. Science and technology of welding and joining, v.12, n.4, p.304-310, 2007.

88.Dumont, M. et al. Microstructure mapping in friction stir welds of 7449 aluminium alloy using SAXS. Acta Materialia, n.54, p.4793-4801, 2006.

89.Reynolds, A. P. et al. Utility of relatively simple models for understanding process parameter effects on FSW. Materials Science Forum, v.426-432, p.2959-2964, 2003.

90.Etter, A. L. et al. Recrystallization mechanisms in $5251 \mathrm{H} 14$ and $5251 \mathrm{O}$ aluminum friction stir welds. Materials Science and Engineering A, v.445-446, p.94-99, Feb. 2007. 
91.Reed-Hill, R. E. Princípios de metalurgia física. Rio de Janeiro: Guanabara Dois. 1982. 10$12 \mathrm{p}$.

92.Cock, T. Aluminium - A light metal. TALAT, 1999. Disponível em: <http://www.eaa.net/eaa/education/TALAT/lectures/110001.pdf $>$. Acesso em: 15 Jul 2008.

93.Lee, C. S.; Smallman, R. E.; Duggan, B. J. Effect of rolling geometry and surface friction on cube texture formation. Materials Science and Technology, v.10, p.149-154, Feb. 1994.

94.Hu, J.; Ikeda, K.; Murakami, T. Effect of texture components on plastic anisotropy and formability of aluminium alloy sheet. Journal of materials processing technology, v.73, p.4956, 1998.

95.Maurice, C.; Driver, J. H. Hot rolling textures of f.c.c. metals - Part I. Experimental results on Al single and polycristals. Acta Materialia, v.45, n.11, p.4627-4638, 1997.

96.Martins, J. P. Evolução da microestrutura e da textura durante o processamento de chapas da liga Al-Mn-Fe-Si (3003) produzidos por lingotamento contínuo: um estudo comparativo com o processo semi-contínuo. 2005. 171 p. Doutor. - Escola Politécnica Engenharia Metalúrgica e de Materiais, Universidade de São Paulo, São Paulo.

97.Fernandes, R. C. Efeito dos teores de manganês e de ferro na evolução microestrutural de duas ligas do sistema Al-Fe-Mn-Si obtidas por lingotamento contínuo. 2006. 184 p. Doutor. - Escola Politécnica - Engenharia Metalúrgica e de Materiais, Universidade de São Paulo, São Paulo.

98.Karlsen, M. et al. Characterisation of the deformation microstructure in friction stir welded 7075 T6 aluminium alloy using the SEM-EBSD technique. In: 3rd International Friction Stir Welding Symposium. Port Island, Kobe, Japan, 27-28 Sept. 2001. p.8.

99.Boswell, P. G. On the calculation of activation energy using a modified Kissinger method. Journal of Thermal Analysis, v.18, p.353-358, 1980. 1980.

100.Montgomery, D. C. Design and analysis of experiments. New York: John Wiley \& Sons. 1996. $704 \mathrm{p}$.

101.Moen, R. D.; Nolan, T. W.; Provost, L. P. Improving quality through planned experimentation. New York: McGraw-Hill. 1991. 414 p. 
102.Box, G. E. P.; Hunter, J. S.; Hunter, W. G. Statistics for experimenters : design, innovation, and discovery: Wiley-Interscience. 2005. 633 p.

103.Chen, Z. W.; Cui, S. On the forming mechanism of banded structures in aluminium alloy friction stir welds. Scripta Materialia, n.58, p.417-420, 2008.

104.Nelson, L. S. Factors for the Analysis of Means. Journal of Quality Technology, n.6, p.175$181,1974$.

105.Pinto, A. L.; Lopes, A. M. A utilização da técnica de EBSD em estudos de microtextura e mesotextura. In: II Workshop sobre Textura e Relações de Orientação. São Paulo. 2003. p.441459.

106.Lima, N. B. D.; Lima, L. M. G. D.; Padilha, A. F. Texturas de Recristalização. In: II Workshop sobre Textura e Relações de Orientação. São Paulo. 2003. p.107-128. 